\title{
Aspects of fatty acid handling in the diabetic rat heart
}

Citation for published version (APA):

Hasselbaink, D. M. (2003). Aspects of fatty acid handling in the diabetic rat heart. [Doctoral Thesis, Maastricht University]. Universiteit Maastricht. https://doi.org/10.26481/dis.20030613dh

Document status and date:

Published: 01/01/2003

DOI:

$10.26481 /$ dis.20030613dh

Document Version:

Publisher's PDF, also known as Version of record

\section{Please check the document version of this publication:}

- A submitted manuscript is the version of the article upon submission and before peer-review. There can be important differences between the submitted version and the official published version of record.

People interested in the research are advised to contact the author for the final version of the publication, or visit the DOI to the publisher's website.

- The final author version and the galley proof are versions of the publication after peer review.

- The final published version features the final layout of the paper including the volume, issue and page numbers.

Link to publication

\footnotetext{
General rights rights.

- You may freely distribute the URL identifying the publication in the public portal. please follow below link for the End User Agreement:

www.umlib.nl/taverne-license

Take down policy

If you believe that this document breaches copyright please contact us at:

repository@maastrichtuniversity.nl

providing details and we will investigate your claim.
}

Copyright and moral rights for the publications made accessible in the public portal are retained by the authors and/or other copyright owners and it is a condition of accessing publications that users recognise and abide by the legal requirements associated with these

- Users may download and print one copy of any publication from the public portal for the purpose of private study or research.

- You may not further distribute the material or use it for any profit-making activity or commercial gain

If the publication is distributed under the terms of Article $25 \mathrm{fa}$ of the Dutch Copyright Act, indicated by the "Taverne" license above, 


\section{ASPECTS OF FATTY ACID HANDLING IN THE DIABETIC RAT HEART}




\section{ASPECTS OF FATTY ACID HANDLING IN THE DIABETIC RAT HEART}

\section{PROEFSCHRIFT}

ter verkrijging van de graad van doctor aan de Universiteit Maastricht, op gezag van de Rector Magnificus, Prof. dr. A.C. Nieuwenhuijzen Kruseman, volgens het besluit van het College van Decanen, in het openbaar te verdedigen op vrijdag 13 juni 2003 om 14.00 uur

door

Danny Marco Hasselbaink

geboren op 31 maart 1973 te Rotterdam 
Promotor:

Prof. dr. G.J. van der Vusse

Beoordelingscommissie:

Prof. dr. R.S. Reneman (voorzitter)

Prof. dir. T.W.A. de Bruin

Prof. dr. L. Havekes (Leids Universitair Medisch Centrum, Leiden)

Dr. H. Keizer

Prof. dr. H.A.J. Struijker Boudier

C D.M. Hasselbaink, Maastricht 2003

ISBN 90-9016934-2 


\section{Contents}

Chapter 1

General introduction

Chapter 2

Fatty acid handling in myocardial tissue

Chapter 3

Determination of long-chain fatty acids,

triacylglycerols and phospholipids by

capillary gas chromatography in cardiac

tissue and blood plasma of normal and

diabetic rats

Chapter 4

Protein acylation in the cardiac muscle cell line, $\mathrm{H} 9 \mathrm{C2}$

Chapter 5

Acylated proteins in normal and

streptozotocin-induced diabetic rat

myocardium

Chapter 6

Ketone bodies disturb fatty acid handling in isolated cardiomyocytes derived from control and streptozotocin-diabetic rats

Chapter 7

Metabolic and genetic adaptations in the streptozotocin-treated rat heart

Chapter 8

General discussion

Summary

Samenvatting

Publications

Curriculum vitae

Dankwoord 


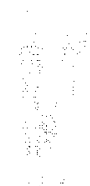




\section{Chapter 1}

General Introduction

Background and aims of the study 


\section{Fatty acid transport and metabolism}

In order to supply the organs in the body with sufficient amounts of blood, the heart is in a continuous need of energy. Although the heart can be considered as an omnivorous organ, circulating long-chain fatty acids (FA) are quantitatively the most important substrates for the heart under normal conditions ${ }^{2}$.

Before FA can be used to sustain the cardiac energy need, FA must be transported across several barriers. In blood plasma FA is bound to albumin or incorporated in triacylglycerols (TG) (figure 1.1). FA can be taken up directly from albumin or via release of FA from circulating TG by lipoprotein lipase (LPL). FA have to cross the luminal membrane, the cytoplasm, and the abluminal membrane of the endothelial cells.

After transport over the endothelial cell layer, it is most likely bound to albumin in the interstitial compartment. The next barrier is the sarcolemma of the cardiomyocytes. There are two possible pathways by which FA can cross the membrane of the cardiomyocytes.

It is a matter of debate whether FA is transported across the sarcolemma via passive diffusion ${ }^{2,3}$ or via protein mediated transport. At present, three proteins are associated which may facilitate FA membrane transport namely, fatty acid translocase (FAT/CD36) ${ }^{4}$, plasmalemmal fatty acid binding protein (FABPpm) ${ }^{5}$ and fatty acid transport protein (FATP) ${ }^{6}$. For the latter protein it is also documented that it possesses fatty acid acyl-CoA synthetase activity ? After FA have crossed the sarcolemma, it is bound to cytoplasmic fatty acidbinding protein (FABPC) ${ }^{8}$, acting as a sink, and most likely involved in the transport through the cytoplasma to the mitochondria. On the outer mitochondrial membrane FA are converted to FA-COA by the enzyme acylCOA synthetase (ACS). FA-CoA can enter multiple pathways. It is documented that FA-COA is bound to acyl-COA binding protein (ACBP), taking care of the further distribution of FA-COA to the several sites of interaction ${ }^{9}$.

In the heart, muscle-type carnitine acyl transferase (mCPT1) is involved in the first step of transport of the fatty acyl chains of FA-COA across the mitochondrial inner membrane, by catalyzing the conversion of FA-COA in FA-carnitine. Inside the mitochondrial matrix FA-COA is reconstituted and stepwise degraded during $\beta$-oxidation to form acetyl-CoA. Subsequently, acetyl-CoA enters the citric acid cycle where it becomes further metabolised. Furthermore, FA-COA can be used for synthesis of diacylglycerols (DG) and from thereon to phospholipids (PL) and TG ${ }^{10}$.

In addition to serving as energy carrying, oxidizable substrates, FA are involved in signal transduction pathways. Evidence is accumulating that FA 
can interact via the peroxisome proliferator activated receptor (PPAR) wi nuclear gene expression resulting in, among others, enhanced production : FA handling proteins ${ }^{11,12}$.

Figure 1.1 Schematic representation of fatty acid uptake, transport, and handling in $t$ cardiomyocyte.

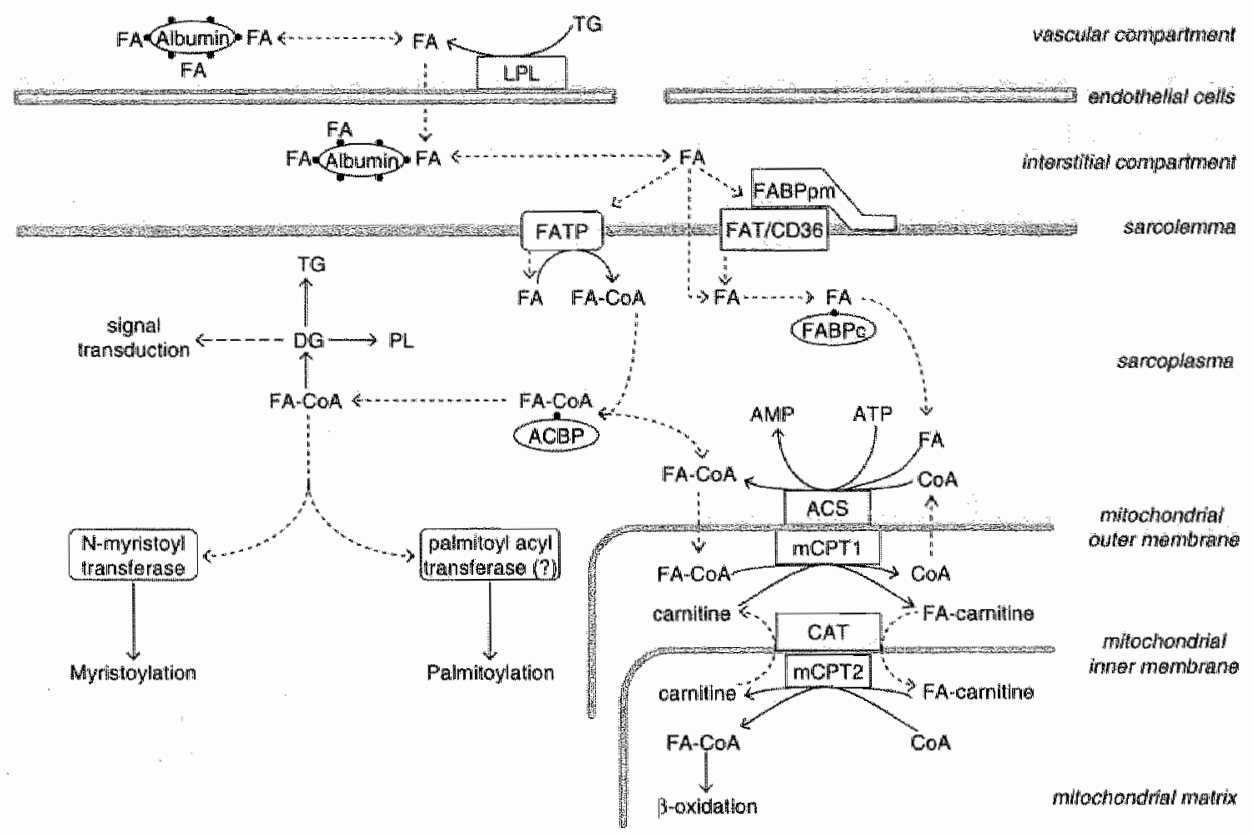

FA, long chain fatty acids; LPL, lipoprotein lipase; TG, triacylglycerols; FATP, fatty ac transport protein; FABPpm, plasmalemmal fatty acid binding protein; FAT/CD36, fatty ac translocase; FA-COA, fatty acyl coenzyme A; FABPC, cytoplasmic fatty acid binding protein; $D$ diacylglycerols; $\mathrm{PL}$, phospholipids; ACBP, acyl-COA binding protein; ACS, acyl-COA synthetas mCPT1/2, muscle-type carnitine palmitoyl transferase 1 or $2 ;$ CAT, carnitine acyltransferase.

Moreover, FA-COA can be used for covalent attachment of FA to protein either via $\mathrm{N}$-myristoyll transferase (NMT) leading to myristoylation ${ }^{13}$ or vi unknown mechanisms to S-acylation (palmitoylation) ${ }^{14}$. The latter processe lead to alterations in cellular localization and/or biological acticvity of th acylated proteins. 
4 / Chapter 1

\section{Diabetes Mellitus}

Diabetes Mellitus is a clinical syndrome characterized by hyperglycemia. It is caused by a relative or absolute deficiency of insulin or resistance to the action of insulin. These two distinct forms of diabetes are named respectively, diabetes type 1 and type 2 . During diabetes the lack (of action) of insulin causes a wide variety of metabolic derangements. This includes abnormal elevation of blood sugar, increases in plasma levels of FA, amino acids, TG, and alterations in hormone levells and plasma ketone bodies ${ }^{15-20}$. Elevations of tissue FA and TG are associated with the development of diabetic cardiomyopathies, although the exact mechanism is not yet known ${ }^{21}$. Experiments on isolated hearts strongly suggest that cardiac FA oxidation is substantially increased in diabetic heart ${ }^{22-24}$ "These findings are, however, at variance with observations in patients and intact animals, indicating no change or even a decline in cardiac FA utilization ${ }^{25}$. Besides the discrepancy, in general, novel therapies are aiming to lower plasma FA and TG levels since they are considered the prime targets in preventing diabetic cardiomyopathies.

\section{Aims}

In the present thesis, the overall aim was to enlarge our knowledge about abnormalities in cardiac FA handling under diabetic conditions. Experiments were performed on a variety of experimental models, including streptozotocin-treated rats to evoke type 1 diabetes, cardiomyocytes isolated from diabetic rat hearts, and $\mathrm{H} 9 \mathrm{C} 2$ cell line, derived from embryonic rat hearts.

The sub-aims of the thesis were:

- Detailed analysis of plasma and cardiac tissue levels of fatty acids (FA), triacylglycerols (TG) and phospholipids (PL) and their relative fatty acyl composition of diabetic rats.

- Assessment of the presence of acylated proteins in cardiac tissue and the effect of diabetes thereon.

- Exploration of the uptake and utilization rate in diabetic cardiomyocytes and the interference of elevated concentrations of ketone bodies.

- Assessment of mechanisms underlying palmitoylation of proteins making use of the embryonic cardiac derived $\mathrm{H} 9 \mathrm{c2}$ cell line 
- Exploration of cardiac adaptation to diabetic conditions on the level of cofactors, enzymes and mRNA. Assessment of the effect of ketone bodies and FA on cardiac gene expression making use of the neonatal cardiomyocyte model.

\section{Scope of the thesis}

In chapter 1 a short introduction concerning cardiac FA handling and diabetes is given and the aims of the study are indicated.

In chapter 2 mechanisms underlying the uptake and oxidation of FA are reviewed. Attention is paid to critical steps in the transport route of FA with special reference to skeletal and heart muscle. Processes underlying protein acylation are discussed in detail.

A sensitive and reliable analytic technique to measure fatty acyl moieties is described in chapter 3. This technique is used to determine the total amount and relative composition of the long-chain FA, triacylglycerols, and phospholipids in cardiac tissue and blood plasma of normal and diabetic rats. Capillary gas chromatography was used to determine the content and relative composition of the acyl chains covalently bound to proteins in cardiac tissue, and to assess the effect of diabetes on protein acylation. The findings are presented in chapter 4 . Furthermore, the influence of ketone bodies on the degree of protein acylation in adult cardiomyocytes derived from control and diabetic rat hearts was investigated.

The H9c2 cell line was used as a model system to explore several aspects of protein acylation in the cardiac muscle. Chapter 5 describes protein acylation as function of time, relative to incorporation of fatty acyl moieties into various lipid classes. Furthermore, the influence of exogenous palmitate on the extent of S-acylation was investigated. In addition, the effect of two inhibitors of protein acylation, tunicamycin and cerulenin, was studied in H9c2 cells.

In chapter 6 the effect of ketone bodies, which are substantially elevated in the diabetic state, on cardiac uptake and fatty acid handling was studied. To this end cardiomyoctes were isolated from control and diabetic rat hearts. The cardiomyocytes were exposed to ketone bodies in the presence of FA levels corresponding with those found in plasma of control and diabetic rats.

Chapter 7 explores several facets ofexperimentally induced diabetes on cardiac metabolism, including tissue content of substrates, cofactors, enzyme activities and mRNA levels. Moreover, in rat neonatal cardiomyocytes the effect of FA and ketone bodies on the expression of metabolic genes was investigated. Special attention is paid to carnitine 
6 / Chapter 1

palmitoyltransferase (CPT1), an enzyme involved in the first step of transporting fatty acyl chains across the mitochondrial inner membrane.

Finally, a general discussion of the results obtained and the implications of diabetes in cardiac FA uptake and handling as well as protein acylation are given in chapter 8. 


\section{References}

1. Van der Vusse, GJ, Glatz, JF, Stam, HC and Rememan, RS. Fatty acid homeostasis in the normoxic and ischemic heart. Physiol Rev 72:881-940, 1992.

2. Hamilton, JA and Kamp, F. How are free fatty acids transported in membranes? Is it by proteins or by free diffusion through the lipids? Diabetes $48: 2255-2269.1999$.

3. Hamilton, JA. Fatty acid transport: difficult or easy? J Lipid Res 39:467-481, 1998.

4. Abumrad, NA, el-Maghrabi, MR, Amri, EZ, Lopez, E and Grimaldi, PA. Cloning of a rat adipocyte membrane protein implicated in binding or transport of long-chain fatty acids that is induced during preadipocyte differentiation. Homology with human CD36. I Biol Chem 268: 17665-17668, 1993.

5. Stremmel, W, Lotz, G, Strohmeyer, G and Berk, PD. Identification, isolation, and partial characterization of a fatty acid binding protein from rat jejunal microvillous membranes. IClin Invest 75: 1068-1076, 1985.

6. Schaffer, JE and Lodish, HF. Expression cloning and characterization of a novel adipocyte long chain fatty acid transport protein. Cell 79:427-436, 1994.

7. Watkins, PA, Lu, JF, Steinberg, SJ, Gould, SJ, Smith, KD and Braiterman, LT. Disruption of the Saccharomyces cerevisiae FAT1 gene decreases very long-chain fatty acyl-CoA synthetase activity and elevates intracellular very long-chain fatty acid concentrations. $f$ Biol Chem 273: 18210-18219, 1998.

8. Storch, $J$ and Thumser, AE. The fatty acid transport function of fatty acid-binding proteins. Biochim Biophys Acta 1486: 28-44, 2000.

9. Knudsen, J, Jensen, MV, Hansen, JK, Faergeman, NJ, Neergaard, TB and Gaigg, B. Role of acylCOA binding protein in acylCOA transport, metabolism and cell signaling. Mol Cell Biochem 192: 95-103, 1999.

10. Jackowski, S, Wang, I and Baburina, I. Activity of the phosphatidylcholine biosynthetic pathway modulates the distribution of fatty acids into glycerolipids in proliferating cells. Biochim Biophys Acta 1483: 301-315, 2000.

11. Van der Lee, KA, De Brouwer, KJF, van der Vusse, GJ and Van Bilsen, M. Fatty acidregulated gene expression in the heart: Inwolvement of peroxisome proliferator-activated receptors. Recent Res. Devel Lipids. 4: 25-38, 2000.

12. Van der Lee, KA, Vork, MM, De Vries, JE, Willemsen, PH, Glatz, JF, Reneman, RS, Van der Vusse, $G$ and Van Bilsen, $M$. Long-chain fatty acid-induced changes in gene expression in neonatal cardiac myocytes. ILipid Res $41: 41-47,2000$.

13. Farazi, TA, Waksman, $G$ and Gordon, J. The biology and enzymology of protein $N$ myristoylation. I Biol Chem 276: 39501-39504, 2001.

14. Resh, MD. Fatty acylation of proteins: new insights into membrane targeting of myristoylated and palmitoylated proteins. Biochim Biophys Acta 1451: 1-16, 1999.

15. Bhathena, 5J. Relationship between fatty acids and the endocitine system. Biofactors 13 : $35-39,2000$. 


\section{Chapter 1}

16. Hagenfeldt,, Dahlquist, $G$ and Persson, B. Plasma amino acids in relation to metabolic control in insulin-dependent diabetic children. Acta Paediatr Scand 78: 278-282, 1989.

17. Hasselbaink, DM, Roemen, TH and Van der Vusse, GJ. Determination of long-chain fatty acids, triacylglycerols and phospholipids by capillary gas chromatography in cardiac tissue and blood plasma of normal and diabetic rats. Anal Chim Acta 465: 351-357, 2002.

18. Owen, OE, Markus, H, Sarshik, 5 and Mozzoli, M. Relationship between plasma an muscle concentrations of ketone bodies and free fatty acids in fed, starved and alloxan-diabetic states. Biochem I/ 134:499-506, 1973.

19. Szabo, A, Kenesel, E, Korner, A, Miltenyi, M, Szucs, L and Nagy, I. Changes in plasma and urinary amino acid levels during diabetic ketoacidosis in children. Diabetes Res Clin Pract 12: $91-97,1991$.

20. Yoshino, $G$, Hirano, $T$ and Kazumi, T. Dyslipidemia in diabetes mellitus. Diabetes Res Clin Pract 33: 1-14, 1996.

21. Rodrigues, B, Cam, MC and McNeill, JH. Metabolic disturbances in diabetic cardiomyopathy. Mol Cell Biochem 180: 53-57,1998.

22. Christe, ME and Rodgers, RL. Cardiac glucose and fatty acid oxidation in the streptozotocin-induced diabetic spontaneously hypertensive rat. Hypertension 25: 235$241,1995$.

23. Rodrigues, $B$ and McNeill, JH. The diabetic heart: metabolic causes for the development of a cardiomyopathy. Cardiovasc Res 26: 913-922, 1992.

24. Saddik, $M$ and Lopaschuk, GD. Triacylglycerol turnover in isolated working hearts of acutely diabetic rats. Can I Physiol Pharmacol 72: 1110-1119, 1994.

25. Turpeilnen, AK, Kuikka, JT, Vanninen, E and Uusitupa, MI. Abnormal myocardial kinetics of 1231-heptadecanoic acid in subjects with impaired glucose tolerance. Diabetologia 40 : $541-549,1997$. 


\section{Chapter 2}

\section{Fatty acid handling in myocardial tissue}

Part of this chapter is published in Ger J. van der Vusse, Marc van Bilsen, Jan F. Glatz, Danny. M. Hasselbaink and Joost.J. Luiken. Critital steps in cellular fatty acid uptake and utilization. Mol. Cell. Biochem 239 (2002), 9-15 


\section{Abstract}

Despite decades of extensive research, the transport routes, mechanisms of uptake, metabolic fate, and points of flux control of long-chain fatty acids (FA) in mammalian organs are still incompletely understood. In non-fenestrated organs such as heart and skeletal muscle, membrane barriers for blood-borne FA are the luminal and abluminal membranes of endothelial cells, the sarcolemma and the mitochondrial membranes. Transport of FA through the phospholipid bilayer of the cellular membrane is most likely accomplished by diffusion of protonated FA. Evidence is accumulating that membrane-associated proteins, such as plasmalemmal Fatty Acid-Binding Protein (FABPpm) and Fatty Acid Translocase (FAT/CD36), either alone or in conjunction with Albumin Binding Protein (ABP), are instrumental in enhancing the delivery of FA to the cellular membrane.

Inside the cell, cytoplasmic Fatty Acid-Binding Proteins (FABPC) are involved in diffusion of FA from the plasmalemma to the intracellular sites of conversion, such as the mitochondrial outer membrane. After conversion of FA to FACOA, the fatty acyl chain is transported across the mitochondrial inner membrane in a carnitine-mediated fashion.

Uptake and utilization of FA by muscle cells are finely tuned, most likely to avoid the intracellular accumulation of FA, as these are cytotoxic at high concentrations. On a short-term basis, net uptake is, among others, regulated by intracellular translocation of FAT from intracellular stores to the sarcolemma and by the concentration gradient of FA across the sarcolemma. The latter implies that, among others, the rate of FA utilization determines the rate of uptake. The rate of FA oxidation is governed by a variety of factors, including malonyl-CoA, the ratio acetylCOA/COA and the availability of competing substrates such as glucose, lactate, and ketone bodies. Besides, FA are also involved in co-translational and posttranslational modification of proteins, i.e., protein acylation. Long-term regulation of uptake and utilization is accomplished by alterations in the expression of genes, encoding for FA-handling proteins. Recent findings indicates that FA themselves are able to modulate the expression of FA-handling genes via nuclear transcription factors such as peroxisome proliferator-activated receptors (PPARs). 


\section{Introduction}

Long-chain fatty acids (FA) are serving a variety of roles in cell homeostasis. In addition to constituents of membrane PL they are substrates for mitochondrial energy conversion and act as energy store after esterification into the TG pool. Moreover, FA are involved in co-translational and post-translational modification of proteins, i.e., protein acylation, and modulate gene expression via interaction with members of the PPAR family ${ }^{1-4}$. Since most organs, including cardiac and skeletal muscle, are not capable of de novo synthesizing FA and possess limited amounts of FA stored in the cytoplasmic compartment, they heavily rely on exogenous FA. The mechanisms underlying the uptake and transport of FA are incompletely understood. In this brief review the potentially critical steps in the transport route of blood-borne FA will be discussed with special reference to heart and skeletal muscle. Moreover, attention is paid to processes underlying acylation of intracellular proteins. These subject matters have been reviewed elsewhere recently ${ }^{1,5-7}$ and will not be addressed in detail here.

\section{Fatty acid handling in myocardial tissue}

\section{Supply of FA to organs}

Circulating FA are supplied to the organ either complexed to plasma albumin or esterified into glycerol, forming the TG core of circulating chylomicrons and very low-density lipoproteins ${ }^{5}$. Prior to uptake by the parenchymal cells, FA are liberated from plasma TG by the catalytic action of lipoprotein lipase, attached to the luminal side of the endothelium ${ }^{2}$.

Both cellular membranes composed of a phospholipid bilayer, and aqueous spaces such as the interstitial and intracellular compartment represent constraints for FA on their route from blood to the mitochondrial outer membrane due to the amphiphilic nature of the FA molecule. The mitochondrial outer membrane is the site where the first committed step in overall FA metabolism takes place, i.e., the activation of FA to fatty-acylCOA catalyzed by acylCoA synthetase (ACS, figure 2.1).

\section{The endothelium and interstitial compartment}

In liver, the FA-albumin complex diffuses through the fenestrae of the endothelium into the spaces of Disse and the interstitial compartment ${ }^{8}$. However, in organs with non-fenestrated endothelium such as cardiac and 
skeletal muscle the endothelial cells lining the microvascular compartment form a serious transport barrier are blood-borne FA. Accordingly, FA needs to be dissociated from their plasma albumin carrier prior to transport through the endothelium ${ }^{9}$.

Figure 2.1 schematic representation of long-chain fatty acid uptake and transport in organs with non-fenestrated endothelium.

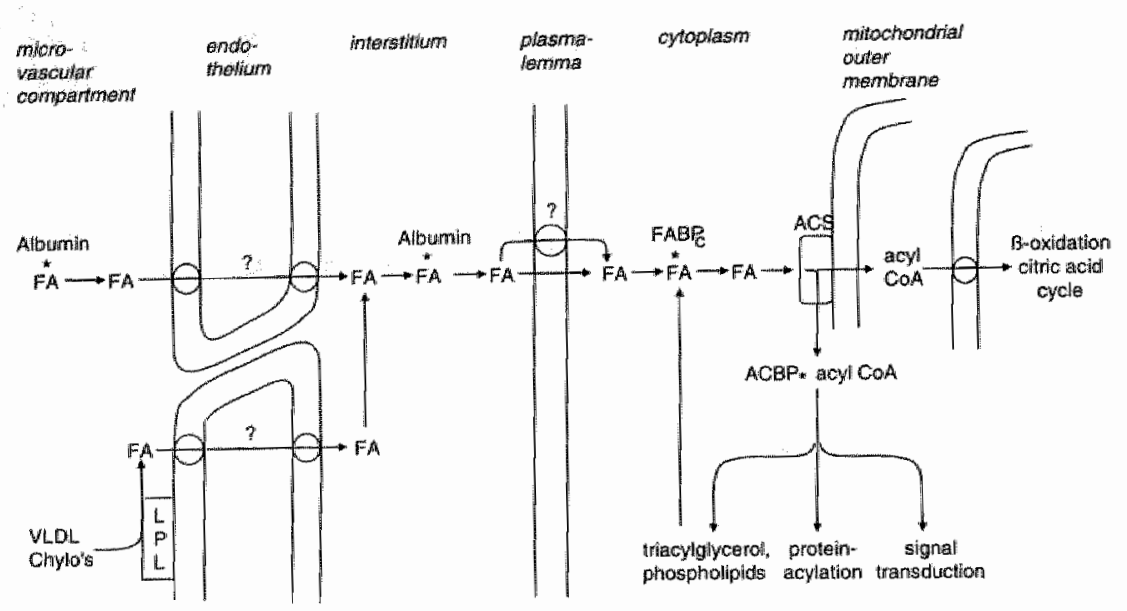

FA, long-chain fatty acid; FABPC, cytoplasmic Fatty Acid-Binding Protein; ACS, acyl COA synthetase; ACBP, ACyl COA-Binding Protein; VLDL, very low density lipoprotein; chylo's, chylomicrons; LPL, lipoprotein lipase.

Circumstantial evidence indicates that in muscle tissue diffusion of FA through the endothelial clefts is inconsequential ${ }^{9}$. The bulk of FA most likely diffuses through the luminal membrane of the endothelial cell, the endothelial cytoplasm and subsequently through the abluminal membrane to be transmitted to albumin present in the interstitial compartment. Detailed information on the mechanisms underlying transendothelial transport of FA in heart and skeletal muscle is, however, lacking.

Earlier studies suggest that specific interaction of the albumin-FA complex with the outer leaflet of the luminal membrane or with proteins associated with the membrane facilitates the dissociation of the FA-albumin complex and, hence, the transfers of FA from the vascular to the interstitial compartment ${ }^{10}$. Endothelial cytoplasmic Fatty Acid-Binding Protein, FABPC, may play a role in the transport of FA from the luminal to the abluminal endothelial membrane. The diffusion of FA from the abluminal membrane to 
the plasmalemma of the parenchymal cell is facilitated by interstitial albumin (figure 2.1).

\section{The sarcolemma}

Recent findings indicate that the plasmalemma (sarcolemma) of cardiac and skeletal muscle cells represent a major constraint for FA, bound to albumin in the interstitial compartment ${ }^{11}$. The traditional view of transport of FA across biological membranes, including the sarcollemma, composed of a phospholipid bilayer is by passive diffusion of protonated FA driven by the concentration difference of FA in the two compartments separated by the membrane ${ }^{12-14}$. Studies on experimental membranes revealed that diffusion of FA through the phospholipid bilayer is fast, leading the investigators to conclude that auxilliary proteins are not required for transmembrane movement of FA ${ }^{14}$. Evidence, however, is accumulating that proteins are involved in the overall transport of FA from the interstitial compartment to the cytoplasm of the parenchymal cell.

At present, at least three different membrane-associated proteins have been identified putatively involved in FA trafficking across the membrane. Stremmel and co-workers ${ }^{25}$ identified a 40-43 $\mathrm{kDa}$ protein in the plasmalemma of hepatocytes, displaying high affinity for FA. This protein, designated plasmalemmal Fatty Acid-Binding Protein, FABPpm, is a peripherally bound protein and expressed in a variety of tissues, including heart and skeletal muscle. Antibodies against FABPpm significantly inhibit the cellular uptake of FA ${ }^{16}$. Later studies by Abumrad and colleagues ${ }^{17}$ established the existence of an $88 \mathrm{kDa}$ integral membrane protein, called Fatty Acid Translocase, FAT, which turned out to be homologous to the human leukocyte differentiation antigen $C D 36$. This protein is expressed in a host of tissues but not in liver ${ }^{17,18}$. Transfection of this membrane protein into fibroblast induced a saturable, high-affinity component of oleate uptake ${ }^{19}$. Thirdly, Schaffer and Lodish ${ }^{20}$ discovered a $63 \mathrm{kDa}$ protein via expression cloning of an adipocyte cDNA library in COS7 cells. More recent findings ${ }^{21}$ indicate that this integral membrane protein, designated Fatty Acid Transport Protein, FATP, possesses catalytic properties, promoting the conversion of FA into fatty-acyICOA, and may therefore modulate the uptake of FA by creating an intracellular sink for FA. Finally, a series of membraneassociated proteins has been discovered expressing a relatively high affinity for albumin ${ }^{22-24}$.

In addition to the earlier mentioned inhibitory effect of antibodies of FABPpm on cellular FA uptake, the outcome of recently performed experiments points towards a quantitatively important role of membrane- 
associated proteins in transmembrane FA transport. Mild treatment of isolated cardiomyocytes with trypsin significantly reduced the uptake of $\mathrm{FA}^{25}$. Phloretin, a universal inhibitor of membrane-associated transport proteins, severely hampered cardiomyocyte FA uptake. Of interest is the fact that also sulfo-N-succinimidyl oleate (S5O), a ligand of FAT/CD36, inhibited FA uptake by isolated cardiomyocytes. More recently it was shown that FA uptake by sarcolemmal giant vesicles prepared from rat heart is also blocked by trypsin, phloretin, SSO, and antibodies against FABPpm ${ }^{26}$. Since these vesicles lack FA converting enzymes an indirect effect of these inhibitory agents on membrane FA transport is rather unlikely. Interestingly, the inhibitory actions of anti-FABPpm and SSO were found to be non-additive, which indicates that FABPpm and FAT/CD36 cooperate in facilitating the translocation of FA across the plasmalemma.

In order to unify the notion that the transport of FA across the phospholipid bilayer of biological membranes is accomplished by passive diffusion with the recent findings that membrane-asociated proteins are involved in cellular FA uptake, we propose the following paradigm. Proteins such as albumin-binding proteins (ABP) are trapping the albumin-FA complex at close vicinity of the outer leaflet of the phospholipid bilayer (figure 2.2).

The interaction of the albumin-FA complex with ABPs facilitates the dissociation of the ligand from the complex. FA accumulating in the stagnant water layer of the extracellular compartment bind to the peripheral membrane protein FABPpm and are subsequently transmitted to the integral membrane protein, FAT/CD36. Alternatively, FA is directly transferred from albumin to FABPpm. This process substantially increases the amount of FA available for transport through the membrane.

The latter is accomplished by passive diffusion of protonated FA, most likely by a flip-flop mechanism of the fatty acyl moieties through the outer and inner leaflet of the phospholipid bilayer. It can, however, not be excluded that FAT/CD36 is physically involved in translocating non-protonated FA through the phospholipid bilayer by facilitated diffusion. Moreover, membrane-associated proteins may also play a crucial role in the release of FA from the inner leaflet of the plasmalemma into the aqueous cytoplasm of
the parenchymcal cell. 
Figure 2.2 Hypothetical transport of long-chain fatty acids across the plasmalemima of a muscle cell.

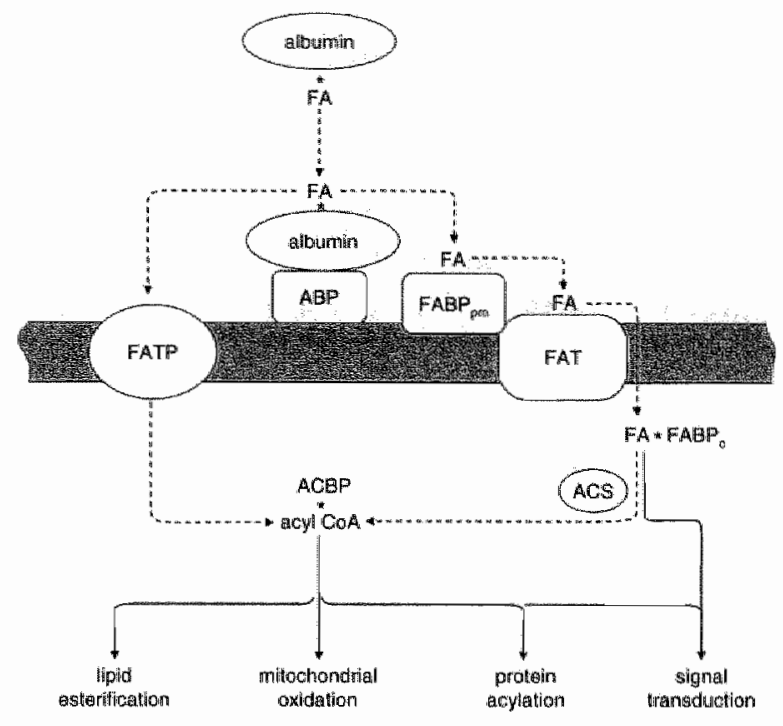

FA, long-chain fatty acid; ABP, albumin-binding protein; FABPpm, plasmalemmal Fatty AcidBinding Protein; FAT, Fatty Acid Translocase; FATP, Fatty Acid Transport Protein; ACBP, ACyl CoA-Binding Protein; ACS, acyl COA synthetase.

\section{The cytoplasm}

Pioneering studies of Ockner and co-workers ${ }^{27}$ have disclosed the presence of cytoplasmic proteins with a high affinity for FA. Mathematical models and in vitro studies have later shown that these proteins, designated Fatty Acid. Binding Proteins, FABPC, are indispensible for bulk transport of FA from the plasmalemma to the main intracellular site of conversion, i.e., the mitochondrial outer membrane, home of fatty acylCoA-synthetase ${ }^{28,29}$. FABPC, a 14-15 kDa protein, consists of a family of at least 13 members, slightly differing in amino acid sequence depending on the cell type of expression. The physiological role of FABPC in cardiac myocytes has recently been firmly established by Binas and co-workers ${ }^{30}$ and Schaap and colleagues ${ }^{31}$. They investigated the FA uptake in the heart of intact mice carrying a targeted disruption of the gene coding for heart-type FABPC, and FA utilization by cardiomyocytes isolated from $\mathrm{H}-\mathrm{FABPC}$ deficient mouse 
heart, respectively. Other studies on immortalised cell lines and other types of parenchymal cells and experiments performed on immortalized cell lines underlines the notion that FABPC is indeed involved in cytoplasmic FA trafficking ${ }^{32}$.

It is still a matter of debate whether FA are transmitted from the inner leaflet of the phospholipid bilayer to FABPC, one, by collisional interaction of $F A B P C$ with the membrane, or two, after release of FA into the water layer adjacent to the membrane prior to binding to FABPC. Evidence provided by Storch and colleagues ${ }^{33}$ indicates that the former mechanism is true for muscle FABPC and the latter for liver FABPC. It is of interest to note that Spitsberg and co-workers observed in the bovine mammary gland physical interaction between soluble FABP and membrane-associated FAT/CD $36{ }^{34}$.

It remains to be established whether FABPC physically interacts with fatty acylCoA-synthetase or with PL domains in close vicinity of the enzyme in the mitochondrial outer membrane. This kind of interaction may facilitate and regulate the transmission of cytoplasmic FA to the enzyme, which catalyses the first committed step in intracellular FA metabolism. The product, fatty acylCoA, serves as substrate for reacylation of $\mathrm{PL}$, formation of the intracellular lipid store, $\mathrm{TG}$, and/or intramitochondrial oxidation to $\mathrm{CO}_{2}$ and $\mathrm{H}_{2} \mathrm{O}$ after transport through the mitochondrial inner membrane in a carnitine-mediated process (figure 2.1). Moreover, acylCoA is also a substrate for the acylation of proteins, i.e. S-acylation and myristoylation. With respect to acylCOA it is important to note that another protein involved in cellular FA handling, namely the cytoplasmic acylCoA-binding protein (ACBP), is thought to be involved in the vectorial delivery of the fatty acyl moieties to the distinct metabolic pathways ${ }^{35,36}$.

\section{Acylation of cellular proteins}

Besides modifications of proteins via e.g. phosphorylation and glycosylation, proteins can also become modified via interactions with hydrophobic moieties. These moieties include isoprenoids (farnesyl and geranylgeranyl), glycosyl-phosphatidyl inositol anchors and, discovered more recently, fatty acids ${ }^{37-40}$. Although the initial observation that proteins were modified with lipids was done in $1956^{41}$, it took until 1969 before a detailed study was performed by Braun and Radin ${ }^{42}$. They showed that FA chains were found neither free nor as part of complex lipids, but instead covalently associated to the myelin proteolipid protein. Several experiments showed that modifications with palmitate and those with myristate were of a different 
nature. Proteins modified by either fatty acid could be distinguisthed from one another ${ }^{43}$.44, and thus represented two distinct classes of protein modification (table 2.1). The myelin proteolipid protein, earlier mentioned, appeared to be modified by palmitate. Protein myristoylation was first described by Carr and collegues, who identified the N-terminal blocking group on the catalytic subunit of A kinase and calcineurin B as tetradecanoate (myristate; $\mathrm{C} 14: 0)^{45,46}$.

There are a number of differences between modifications with myristate and palmitate. Myristoylation occurs through amide linkages on the $\mathrm{N}$-terminal glycine residue after removal of the initiator methionine, and this attachment takes place during protein synthesis, e.g. co-translational modification. Furthermore, myristoylation is highly specific due to the strict substrate selectivity of the enzyme responsible for myristoylation, e.g. $\mathrm{N}$-myristoyltransferase ${ }^{38,47}$. Generaly, the attached myristic acid is stable and has a half-life similar to that of the protein to which it is bound. There are, however, two reports indicating that demyristoylation of particular proteins can occur ${ }^{48,49}$. Palmitoylation, or S-acylation, occurs on cysteine residues through a thioester linkage in a wide variety of sequence contexts, and is a post-translational modification. While palmitate is the most common fatty acid involved in this type of modification, other FA can also become incorporated into cellular proteins via a thioester linkage, including myristate, stearate, and arachidonate ${ }^{50,51}$. In general, S-acylation is a dynamic modification with a half-life of the fatty acyl moieties shorter than that of the polypeptide backbone, indicating the existence of palmitoylation / depalmitoylation cycles ${ }^{52-54}$. Caveolin-1, a protein which is S-acylated, is the only known protein not to undergo depalmitoylation ${ }^{55}$. In contrast to myristoylation, the enzymology underlying S-acylation and deacylation is unknown.

There is still controversy whether S-acylation takes place in a nonenzymatic or in an enzymatic fashion. Although several in vitro studies showed that S-acylation can take place in the absence of enzymes ${ }^{56,90-92}$, evidence is accumulating that the same does not hold true in vivo. Leventis and colleagues ${ }^{93}$ have shown in an in vitro study that non-enzymatic S-acylation was inhibited at physiological ratios of ACBP-acylCoA, leading to a substantial increase in the half time of the turnover rate of the acyl moiety. 
Table 2.1 Acylated proteins in the heart

\begin{tabular}{|c|c|}
\hline Palmitoylated proteins & \\
\hline Goo, Gos, Goil, Gouz ${ }^{56-58}$ & GLUT1 59 \\
\hline H-ras, N-ras, Ki-ras ${ }^{60}$ & PSD-95 \\
\hline Src family (Ves, Fgr, Fyn, Lck) & $\mathrm{CD}_{36}^{66}$ \\
\hline a2-adrenergic receptor ${ }^{67}$ & Caveolin-1 ${ }^{68}$ \\
\hline 82-adrenergic receptor ${ }^{67}$ & Phopholipase-D1 ${ }^{69}$ \\
\hline lrisulin receptor ( $\alpha$ and $\beta$ subunits $)^{70,71}$ & Phospolipid scramblase ${ }^{72}$ \\
\hline Mannose-6-phosphate receptor ${ }^{73}$ & $\mathrm{PKC}^{74}$ \\
\hline L-type calcium channel $(\beta 2 \alpha \text {-subunit })^{75}$ & $\operatorname{eNOS}^{76}$ \\
\hline Sodium channels ( $\alpha$-subunit) ${ }^{77}$ & $|G F-1|^{71}$ \\
\hline GRK6 $6^{54}$ & RGS3, RGS4, RGS10, RGS16 78.80 \\
\hline \multicolumn{2}{|l|}{ Myristoylated proteins } \\
\hline Goo, Goil, Got $\operatorname{Cox}^{58,81,82}$ & Arf family 83,84 \\
\hline NADH cytochrome b5 reductase ${ }^{85}$ & Calcineurin $\mathrm{B}^{86}$ \\
\hline Nitric oxide synthase ${ }^{87}$ & AKAP $18^{88}$ \\
\hline Src family (Src, Yes, Fyn, Lck, Hck, Fgr, Yrk, Blk) & \\
\hline
\end{tabular}

Although no palmitoyl acyl transferase (PPT) protein has been purified, which can account for S-acylation, two groups have reported partial purification of enzymatic activity responsible for palmitoylation of a subset of proteins 94. 95. Furthermore, three groups purified PATs responsible for $S$-acylation of specific proteins, while it is not known whether other proteins can serve as substrates ${ }^{96-98}$. When considering the enzymology of deacylation, two thioesterases have been identified which are capable to remove palmitate from palmitoylated proteins, namely PPT1 and APT1. PTT1 is localised in the lysosome and thus an unlikely candidate for deacylation of plasmamembrane bound proteins. PPT1 is associated with a lysosomal storage disease, infantile neuronal ceroid lipofucscinosis. During this disease small lipid thioesters, which are presumably substrates for PPT1, accumulate leading eventually to death. APT1, an enzyme which originally had been identified as a lysophospholipase, depalmitoylates $G \alpha$ subunits and Ras in vitro and in vivo. Additional information about the substrate specificity of PPT1 or APT1 is lacking. Likely, other palmitoyl protein thioesterases will exist with different substrate specificities of these enzymes and for different classes of proteins.

Although numeral proteins are identified undergoing acylation (table 2.1), the precise role of protein acylation is still not clear. While protein acylation has been associated with a number of functional consequences 
such as membrane targeting/binding (ras p21) ${ }^{99}$, conformational changes (rhodopsine) ${ }^{100}$, regulation of protein function (RGS, GRK6) ${ }^{78,101}$, protection against proteolysis (A1 adenosine receptor) ${ }^{102}$, protein-protein interactions (tetraspanin) ${ }^{103}$, for the majority of acylated proteins the role of acylation is not clearly established and remains to be elucidated.

\section{Regulation of cellular FA utilization}

In tissues, such as the heart and skeletal muscle, FA are important oxidizable substrates. Over $70 \%$ of energy consumed for electro-mechanical activity is covered by mitochondrial oxidation of $F^{2}{ }^{2}$. The accompanying FA flux from the vascular compartment to the mitochondrial matrix is on the order of 100-150 $\mathrm{nmol}$ fatty acyl moieties $\mathrm{gram}^{-1}$ per minute. In resting skeletal muscle blood-borne FA utilization is minor, but during prolonged muscular contractile activity FA uptake readily increases to $200 \mathrm{nmol} \cdot \mathrm{g}^{-1}$ per minute ${ }^{104}$.

Under physiological conditions, uptake is in equilibrium to mitochondrial utilization, to prevent intracellular accumulation of FA, being highly toxic at elevated intracellular concentrations ${ }^{2}$. The endogenous TG pool acts most likely as an intracellular capacitor to absorb temporary imbalances in uptake and utilization of exogenous FA. The intracellular FA concentration is also kept as low as possible to create a concentration difference between interstitial and cytoplasmic FA, which is required as driving force for the transition of FA from the extracellular to the intracellular compartment. Noteworthy is the observation of Kiens and co-workers ${ }^{105}$ that during skeletal muscle activity at moderate intensity the cellular FA concentration decreases compared to the resting state, promoting the diffusion of bloodborne FA to the muscle cell interior.

Recent findings of Bonen and colleagues ${ }^{106}$ indicate that the capacity to extract FA from extracellular sources is also regulated during acute changes in muscle energy requirements. They observed that sarcolemmal giant vesicles prepared from muscles that were electrically stimulated for $25 \mathrm{~min}$ display a substantially higher rate of FA uptake than vesicles from nonstimulated muscles. The increase was paralleled by a higher sarcolemmal content of FAT/CD 36, most likely due to translocation of the FA transporting protein from an intracellular pool to the cell membrane. Of interest is that insulin is also able to promote the translocation of FAT/CD36 from the intracellular storage site to the sarcolemma ${ }^{107}$. In addition to translocation, the biological activity of FAT/CD36 may be acutely modulated by phosphorylation of the membrane-associated protein ${ }^{108}$. 
Mitochondrial acyl-CoA formation and/or subsequent oxidation of fatty acyl chains via B-oxidation and citric acid cycle activity offers (an) additional site(s) of control of the rate of muscular FA utilization. The actual regulation of mitochondrial FA oxidation is a multifactorial process in which malonyl $\mathrm{CoA}$, the ratio acetyl COA/COA and $\mathrm{NADH} / \mathrm{NAD}^{+}$play prominent roles ${ }^{2}$. Moreover, the availability of competing substrates such as lactate has profound effects on the rate of muscular FA oxidation. The collected findings indicate that both the rate of mitochondrial FA utilization and the rate of transport of FA from the interstitital compartment into the myocyte interior contribute to the overall rate of muscle cell FA utilization.

\section{Long-term adaptation of cellular FA uptake and transport}

Various lines of evidence suggest that chronic alterations in the cellular utilization of FA can be attributed to adjustment of the expression of genes encoding for proteins involved in FA uptake, transport and metabolism. Experiments performed on adipocytes and hepatocytes indicated that substrates for energy conversion themselves are capable of modulating the transcriptional activity of metabolic genes ${ }^{109-112}$. We observed recently in cultured neonatal cardiac muscle cells ${ }^{4,113}$ that exogenous FA are also capable to control cardiac transcriptional activity. Chronic exposure of the neonatal cardiomyocytes to physiological concentrations of oleate and palmitate in the incubation medium for $48 \mathrm{~h}$ resulted in a 3 -fold increase in the mRNA levels of FAT/CD 36 and FABP ${ }^{113}$. In addition, the transcription of two mitochondrial FA-handling enzymes, acyl CoA synthetase and long-chain acyl-CoA dehydrogenase increased substantially. In this respect it is of interest to note that in the healthy rat, deprivation of food for $48 \mathrm{~h}$ increased the plasma FA concentration almost 2-fold, associated with an increase in the cardiac tissue levels of FAT/CD36 and FABPC mRNA ${ }^{114}$. Moreover, the maturational increase in rat cardiac FA oxidation, starting a couple of days after birth ${ }^{115 .}{ }^{116}$, was found to be accompanied by an increased content of FAT/CD 36 and of cytoplasmic FABP in the myocardium ${ }^{18,117}$.

The finding that chronic exposure of cardiomyocytes to exogenous FA results in the transcriptional upregulation of a variety of FA-handling genes indicates that the cells are capable of sensing changes in the supply of FA and/or FA derivatives. Recent studies ${ }^{3,118}$ revealed that the promoter region of FAT/CD36 containes cis-regulatory elements with binding sites for transcription factors such as COUP/TF, PPAR, RXR, and HFN-4 ${ }^{118,119}$. PPAR is a likely candidate for cellular FA sensing, since FA may act as natural ligand of the PPAR5 ${ }^{120-122}$. In particular, the PPAR and PPARß isoforms may be involved 
in modulating transcriptional activity in cardiomyocytes by FA, as cardiac tissue lacks the expression of PPAR.

\section{Future directions}

Despite many attempts to elucidate in full detail the molecular mechanism of cellular fatty acid uptake, transport and utilization, the complete picture of transport routes and regulatory processes is still missing. It is for instance unknown whether FA released from the triacylglycerol core of circulating lipoproteins mix with FA supplied by albumin in the microvascular compartment prior to transport through the endothelium and utilization in the parenchymal cells. The route of FA transport across the endothelium and the mechanisms involved are still enigmatic. The precise mechanism of transport of FA across a biological membrane, consisting of a phospholipid bilayer, is incompletely understood. The question as to whether membraneassociated proteins promote the FA membrane trafficking per se or enhance the availability of FA at close vicinity of the membrane remains to be answered. Moreover, it is unclear whether the putative membraneassociated FA binding proteins are acting in concert. The role of albuminbinding proteins attached the cellular membranes in cellular FA uptake and transport remains to be established.

Since evidence is accumulating that proteins involved in cellular FA uptake, such as FAT/CD36, can be mobilized from intracellular sites, future studies should be performed to elucidate the nature of the signalling pathways resulting in translocation of membrane FA-binding proteins.

The fine-tuning between mitochondrial FA oxidation and cellular FA uptake and transport is only partly understood, but it is becoming evident that factors increasing mitochondrial activity also act on signalling pathways involved in FAT/CD 6 translocation. Finally, the investigation on the transcriptional regulation of genes encoding for proteins involved in tissue FA handling state is in its infancy. Detailed information is required to elucidate both the long-term regulation of FA-handling under physiological conditions and the impact of alterations in FA-handling in the diseased state. The latter is of utmost importance to fully appreciate the alterations in FA handling by the diabetic heart and to elucidate the potential role of FA in processes leading to diabetic cardiomyopathy. 


\section{References}

1. Resh, MD. Fatty acylation of proteins: new insights into membrane targeting of myristoylated and palmitoylated proteins. Biochim Biophys Acta 1451: 1-16, 1999.

2. Van der Vusse, GJ, Glatz, JF, Stam, HC and Reneman, RS. Fatty acid homeostasis in the nomoxic and ischemic heart. Physiol Rev 72: 881-940, 1992.

3. Van Bilsen, $M$, Van der Vusse, $G$ and Reneman, RS. Transcriptional regulation of metabolic processes: Implications for cardiac metabolism. Pflugers Arch 437: 2-14, 1998.

4. Van Bilsen, $M$, de Vries, JE and Van der Vusse, G. Long-term effects of fatty acids on cell viability and gene expression of neonatal cardiac myocytes. Prostagiandins Leukot Essent Fatty Acids $57: 39-45,1997$.

5. Van der Vusse, GJ, van Bilsen, $M$ and Glatz, JF. Cardiac fatty acid uptake and transport in health and disease. Cardiavasc Res 45: 279-293, 2000.

6. Glatz, JF, Van Nieuwenhoven, FA, Luiken, J, Schaap, FG and Van der Vusse, GJ. Role of membrane-associated and cytoplasmic fatty acid-binding proteins in cellular fatty acid metabolism. Prostaglandins Leukot Essent Fatty Acids 57: 373-378, 1997.

7. Dunphy, JT and Linder, ME. Signalling functions of protein palmitoylation. Biochim Biophys Acta 1436: 245-261, 1998.

8. Weisiger, RA, Pond, 5 and Bass, L. Hepatic uptake of protein-bound ligands: extended sinusoidal perfusion model. Am J Physiol 261: G872-884, 1991.

9. Bassingthwaighte, JB, Noodleman, $L$, van der Vusse, $G$ and Glatz, JF. Modeling of palmitate transport in the heart. Mol Cell Biochem 88: 51-58, 1989.

10. Van der Vusse, GI, Glatz, JF, Van Nieuwenhoven, FA, Reneman, RS and Bassingthwaighte, JB. Transport of long-chain fatty acids across the muscular endothelium. Adv Exp Med Biol 441: 181-191, 1998.

11. Luiken, JJ, Glatz, JF and Bonen, A. Fatty acid transport proteins facilitate fatty acid uptake in skeletal muscle. Can J App/ Physiol 25: 333-352, 2000.

12. Zakim, D. Thermodynamics of fatty acid transfer. I Membr Biol 176:101-109, 2000.

13. Zakim, D. Fatty acids enter cells by simple diffusion. Proc Soc Exp Biol Med 212: 5-14, 1996.

14. Hamilton, IA and Kamp, F. How are free fatty acids transported in membranes? Is it by proteins or by free diffusion through the lipids? Diabetes 48: 2255-2269, 1999.

15. Stremmel, W, Strohmeyer, G, Borchard, F, Kochwa, $S$ and Berk, PD. isolation and partial characterization of a fatty acid binding protein in rat liver plasma membranes. Proc Nati Acad Sci U S A 82: 4-8, 1985.

16. Sorrentino, D, Stump, D, Potter, BJ, Robinson, RB, White, R, Kiang, CL and Berk, PD. Oleate uptake by cardiac myocytes is carrier mediated and involves a 40-kD plasma membrane fatty acid binding protein similar to that in liver, adipose tissue, and gut. $J$ Clin Invest 82 : 928-935, 1988. 
17. Abumrad, NA, el-Maghrabi, MR, Amri, EZ, Lopez, E and Grimaldi, PA. Cloning of a rat adipocyte membrane protein implicated in binding or transport of long-chain fatty acids that is induced during preadipocyte differentiation. Homology with human CD36. J Biol Chem 268: 17665-17668, 1993.

18. Van Nieuwenhoven, FA, Willemsen, PH, Van der Vusse, $G$ and Glatz, JF. Co-expression in rat heart and skeletal muscle of four genes coding for proteins implicated in long-chain fatty acid uptake. Int I Biochem Cell Biol 31: 489-498, 1999.

19. Ibrahimi, A, Sfeir, Z, Magharaie, H, Amri, EZ, Grimaldi, P and Abumrad, NA. Expression of the CD36 homolog (FAT) in fibroblast cells: effects on fatty acid transport. Proc Nat/ Acad SciU S A 93: 2646-2651, 1996.

20. Schaffer, JE and Lodish, HF, Expression cloning and characterization of a novel adipocyte long chain fatty acid transport protein. Cell 79: 427-436, 1994.

21. Herrmann, T, Buchkremer, F, Gosch, I, Hall, AM, Bernllohr, DA and Stremmel, W. Mouse fatty acid transport protein 4 (FATP4): characterization of the gene and functional assessment as a very long chain acyl-CoA synthetase. Gene 270: 31-40, 2001.

22. Schnitzer, JE, Sung, A, Horvat, R and Bravo, J. Preferential interaction of albumin-binding proteins, gP30 and gp18, with conformationally modified albumins. Presence in many cells and tissues with a possible role in catabolism. J Biol Chem 267: 24544-24553, 1992.

23. Tiruppathi, C, Finnegan, $\mathbf{A}$ and Malik, AB. \|solation and characterization of a cell surface albumin-binding protein from vascular endothelial cells. Proc Nat/ Acad SCI U S A 93: 250$254,1996$.

24. Popov, D, Hasu, M, Ghinea, N, Simionescu, $\mathbf{N}$ and Simionescu, $\mathbf{M}$. Cardiomyocytes express albumin binding proteins. I Mol Cell Cardiol 24: 989-1002, 1992.

25. Luiken, JJ, van Nieuwenhoven, FA, America, G, van der Vusse, GJ and Glatz, JF. Uptalke and metabolism of palmitate by isolated cardiac myocytes from adult rats: involvement of sarcolemmal proteins.. J Lipid Res 38: 745-758, 1997.

26. Luiken, J, Turcotte, LP and Bonen, A. Protein-mediated palmitate uptake and expression of fatty acid transport proteins in heart glant vesicles. I Lipid Res 40: 1007-1016, 1999.

27. Ockner, RK, Manning, JA, Poppenhausen, RB and Ho, WK. A binding protein for fatty acids in cytosol of intestinal mucosa, liver, myocardium, and other tissues. Science 177: 56-58, 1972.

28. Vork, MM, Glatz, JF and Van der Vusse, GJ. Modelling intracellular fatty acid transport: possible mechanistic rolle of cytoplasmic fatty acid-binding protein. Prostaglandins Leukot Essent Fatty Acids 57: 11-16, 1997.

29. Peeters, RA and Veerkamp, JH. Does fatty acid-binding protein play a role in fatty acid transport? Mol Cell Biochem 88: 45-49, 1989.

30. Binas, B, Danneberg, H, McWhir, J, Mullins, L and Clark, AJ. Requilrement for the heart-type fatty acid binding protein in cardiac fatty acid utilization. Faseb J 13: 805-812, 1999. 


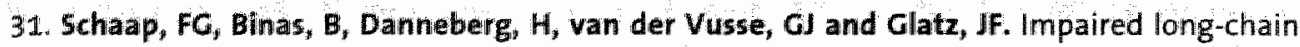
fatty acid utilization by cardlac myocytes isolated from mice lacking the heart-type fatty acid binding protein gene. Circ Res 85: 329 337, 1999.

32. Glatz, JF and Storch, J. Unravelling the significance of cellular fatty acid-binding proteins. Curr Opin Lipidol 12: $267-274,2001$.

33. Storch, $J$ and Thumser, AE. The fatty acid transport function of fatty acid-binding proteins. Biochim Biophys Acto 1486: 28-44, 2000.

34. Spitsberg, VL, Matitashvili, E and Gorewit, RC. Association and coexpression of fatty-acidbinding protein and glycoprotein CD 36 in the bovire mammary gland. Eur J Biochem 230 : $872-878,1995$.

35. Faergeman, $\mathbf{N}$ and Kmudsen, J. Role of long-chain fatty acyl-CoA esters in the regulation of metabolism and in cell signalling. Biochem J 323 (Pt 1): 1-12, 1997.

36. Knudsen, J, Jensen, MV, Hansen, JK, Faergeman, NJ, Meergaard, TB and Gaigg, B. Role of acylCOA binding protein in acylCOA transport, metabolism and cell signaling. Mol Cell Biochem 192: 95-103, 1999.

37. Casey, PJ. Protein lipidation in cell signaling. Sicience 268: 221-225, 1995.

38. Johnson, DR, Bhatnagar, RS, Knoll, $\amalg$ and Gordon, Jl. Genetic and biochemical studies of protein N-myristoylation. Annu Rev Biochem 63: 869-914, 1994.

39. Milligan, G, Parenti, $M$ and Magee, Al. The dynamic role of palmitoylation in signal transduction. Trends Biochem Sci 20: 181-187, 1995.

40. Takeda, J and Kinoshita, T. GPI-anchor biosynthesis. Trends Biochem Sci 20: 367-371, 1995.

4.1. Folch-Pi, $J$ and Lees, $M$. Proteolipids, a new type of tissue lipoprotein. Their isolation from brain. J Biol Chem 191: 807-817, 1956.

4.2. Braun, PE and Radin, NS. Interaction of lipids with a membrane structural protein from myellin. Biochemistry 8: 4310-4318, 1969.

43. Magee, Al and Courtneidge, SA. Two classes of fatty acid acylated proteins exist in eukaryotic cells. Embo J 4: 1137-1144, 1985.

44. Mcllhinney, RA, Pelly, SJ, Chadwick, IK and Cowley, GP. Studies on the attachment of myristic and palmitic acid to cell proteins in human squamous carcinoma cell lines: evidence for two pathways. Embo / 4: 1145-1152, 1985.

45. Carr, SA, Biemann, K, Shoji, S, Parmelee, DC and Titani, K. n-Tetradecanoyl is the NHzterminal blocking group of the catalytic subunit of cyclic AMP-dependent protein kinase from bovine cardiac muscle. Proc Nati Acad Sci U 5 A 79: 6128-6131, 1982.

46. Aitken, $\mathbf{A}$ and Cohen, $\mathbf{P}$. Identification of $\mathbf{N}$-terminal myristyl blocking groups in proteins. Methods Enzymol 106: 205-210, 1984.

47. Boutin, JA. Myristoylation. Cell Signal 9: 15-35, 1997.

48. da Silva, AM and Klein, C. A rapid posttranslational myristoylation of a $68-k D$ protein in D. discoideum. J Cell Biol 111: 401-407, 1990. 
49. Manenti, S, Sorokine, $O$, Van Dorsselaer, A and Taniguchi, $H$. Demyristoylation of the major substrate of protein kinase C (MARCKS) by the cytoplasmic fraction of brain synaptosomes. J Biol Chem 269: 8309-8313, 1994.

50. Van Cott, EM, Muszbek; L and Laposata, M. Fatty acid acylation of platelet proteins. Prostaglandins Leukot Essent Fatty Acids 57: 33-37, 1997.

51. Muszbek, L, Haramura, G, Cluette-Brown, JE, Van Cott, EM and Laposata, M. The pool of fatty acids covalently bound to platelet proteins by thioester linkages can be altered by exogenously supplied fatty acids. Lipids 34: S331-337, 1999.

52. Coats, SG, Booden, MA and Buss, JE. Transient palmitoylation supports H-Ras membrane binding but only partial biological activity. Biochemistry 38: 12926-12934, 1999.

53. Loisel, TP, Adam, L, Hebert, TE and Bouvier, M. Agonist stimulation increases the turnover" rate of beta $2 \mathrm{AR}-$ bound palmitate and promotes receptor depalmitoylation. Biochemistry 35: 15923-15932, 1996.

54. Stoffel, RH, Randall, RR, Premont, RT, Lefkowitz, RJ and Ingllese, J. Palmitoylation of $G$ protein-coupled receptor kinase, GRK6. Lipid modification diversity in the GRK family. J Biol Chem 269: 27791-27794, 1994.

55. Parat, MO and Fox, PL. Palmitoylation of caveolin-1 in endothelial cells is posttranslational but irreversible. J Biol Chem 276: 15776-15782., 2001.

56. Duncan, JA and Gilman, AG. Autoacylation of G protein alpha subunits. J Biol Chem 271: 23594-23600, 1996.

57. Jones, TL and Gutkind, J5. Galpha12 requires acylation for its transforming activity. Biochemistry 37: 3196-3202, 1998.

58. Wilson, PT and Bourne, HR. Fatty acylation of alpha z. Effects of palmitoylation and myristoylation on alpha z signaling. J Biol Chem 270: 9667-9675, 1995.

59. Pouliot, JIF and Beliveau, R. Palmitoylation of the glucose transporter in blood-brain barrier capillaries. Biochim Biophys Acta 1234: 191-196, 1995.

60. Hancock, JF, Magee, Al, Childs, JE and Marshall, CJ. All ras proteins are polyisoprenylated but only some are palmitoylated. Cell 57: 1167-1177, 1989.

61. Wong, W, Newell, EW, Jugloff, DG, Jones, OT and Schlichter, LC. Cell surface targeting and clustering interactions between heterologously expressed PSD-95 and the Shal voltage* gated potassium channel, Kw4.2. I Biol Chem 277: 20423-20430, 2002.

62. Alland, L, Peseckis, SM, Atherton, RE, Berthiaume, L and Resh, MD. Dual myristylation and palmitylation of Src family member p59fyn affects subcellular localization. J Biol Chem 269: 16701-16705, 1994 .

63. Koegl, M, Zlatkine, P, Ley, SC, Courtneidge, SA and Magee, Al. Palmitoylation of multiple Src-family kinases at a homologous N-terminal motif. Biochem / 303: 749-753, 1994.

64. Shenoy-Scaria, AM, Dietzen, DJ, Kwong, J, Link, DC and Lublin, DM. Cysteine 3 of Src family protein tyrosine kinase determines palmitoylation and localization in caveolae. 1 Cell Biol 126: $353-363,1994$. 
65. Shenoy-Scaria, AM, Gauen, LK, Kwong, J, Shaw, AS and Lublin, DM. Pallititation of an amino-terminal cysteine motif of protein tyrosine kinases p56lck and p59fyn mediates interaction with glycosyl-phosphatidylinositol-anchored proteins. Mol Cell Blol 13: 6385 $6392,1993$.

66. Tao, N, Wagner, SJ and Lublin, DM. CD36 is palmitoylated on both $\mathrm{N}$ - and C-terminai cytoplasmic talls, J Biol Chem 271: 22315-22320, 1996.

67. Kennedy, ME and Limbird, LE. Mutations of the alpha 2A-adrenergic receptor that eliminate detectable palmitoylation do not perturb receptor-G-protein coupling. $j$ Bial Chem 268: 8003-8011, 1993 .

68. Dietzen, DJ, Hastings, WR and Lublin, DM. Caveolin is palmitoylated on multiple cysteine residues. Palmitoylation is not necessary for localization of caveolin to caveolae. J Biol Chem 270: 6838-6842, 1995 .

69. Manifava, M, Sugars, J and Ktistakis, NT. Modification of catalytically active phospholipase D1 with fatty acid in wivo. I Blol Chem 274: 1072-1077, 1999.

70. Hedo, JA, Collier, E and Watkinson, A. Myristyl and palmityl acylation of the insulin receptor. J Biol Chem 262: 954-957, 1987.

71. Magee, Al and Siddle, K. Insulin and IGF-1 receptors contain covalently bound palmitic acid. $J$ Cell Biochem 37: 347-357, 1988.

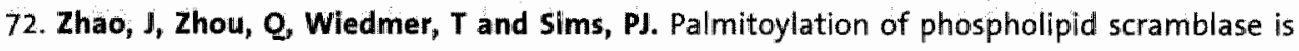
required for normal function in promoting Ca2+-activated transbilayer movement of membrane phospholipids. Biochemistry 37:6361-6366, 1998.

73. Schweizer, A, Kornfeld, 5 and Rohrer, J. Cysteine 34 of the cytoplasmic tail of the cationdependent mannose 6- phosphate receptor is reversibly palmitoylated and required for normal trafficking and lysosomal enzyme sorting. I Cell Biol 132: 577-584, 1996.

74. Ford, DA, Horner, CC and Gross, RW. Protein kinase $C$ acylation by palmitoyl coenzyme A facilitates its translocation to membranes. Biochemistry 37: 11953-11961, 1998.

75. Chien, AJ, Carr, KM, Shirokov, RE, Rios, E and Hosey, MM. Identification of palmitoylation sites within the L-type calcium channel beta2a subunit and effects on channel function. $J$ Biol Chem 271: 26465-26468, 1996.

76. Liu, I, Garcia-Cardena, G and Sessa, WC. Biosynthesis and palmitoylation of endothelial nitric oxide synthase: mutagenesis of palmitoylation sites, cysteines-15 and/or -26 , argues againsit depalmitoylation-induced translocation of the enzyme. Biochemistry 34: 12333$12340,1995$.

77. Schmidt, JW and Catterall, WA. Palmitylation, sulfation, and glycosylation of the alpha subunit of the sodium channel. Role of post-translational modifications in channel assembly. I Biol Chem 262: 13713-13723, 1987.

78. Druey, KM, Ugur, $O$, Caron, JM, Chen, CK, Backlund, P5 and Jones, TL. Amino-terminal cysteine residues of RGS16 are required for palmitoylation and modulation of Gi- and Gqmediated signaling. J Biol Chem 274: 18836-18842, 1999. 
79. Castro-Fernandez, C, Janovick, JA, Brothers, SP, Fisher, RA, Ji, TH and Conn, PM. Regulation of RGS3 and RGS10 palmitoylation by GnRH. Endocrinology 143: 1310-1317, 2002.

80. Tu, $\mathrm{Y}$, Popov, $\mathbf{S}_{\mathrm{s}}$ Slaughter, $\mathbf{C}$ and Ross, EM. Palmitoylation of a conserved cysteine in the regulator of $G$ protein signaling (RGS) domain modulates the GTPase-activating activity of RGS4 and RGS10. J Biol Chem 274: 38260-38267, 1999.

81. Jones, TL, Simonds, WF, Merendino, JJ, Brann, MR and Spiegel, AM. Myristoylation of an inhibitory GTP-binding protein alpha subunit is essential for its membrane attachment. Proc Natl Acad Sci U S A 87: 568-572, 1990.

82. Mumby, SM and Linder, ME. Myristoylation of G-protein alpha subunits. Methods Enzymol 237: 254-268, 1994.

83. Berger, S」, Resing, KA, Taylor, TC and Melancon, P. Mass-spectrometic analysis of ADPribosylation factors from bovine brain: identification and evidence for homogeneous. acylation with the C14:0 fatty acid (myristate). Biochem J 311: 125-132, 1995.

84. Millar, CA, Powell, KA, Hickson, GR, Bader, MF and Gould, GW. Evidence for a role for ADPribosylation factor 6 in insulin-stimulated g/ucose transponter-4 (GLUT4) trafficking in 3T3L1 adipocytes. I Biol Chem 274: 17619-17625, 1999.

85. Ozols, J, Carr, 5A and Strittmatter, P. Identification of the $\mathrm{NH2}$-terminal blocking group of the NADH-cytochrome b5 reductase as myristic acid and the complete amino acid sequence of the membrane-binding domain.J Biol Chem 259: 1984.

86. Aitken, A, Cohen, P, Santikarn, S, Williams, DH, Calder, AG, Smith, A and Klee, CB. Identification of the $\mathrm{NH2}$-terminal blocking group of calcineurin $\mathrm{B}$ as myristic acid. FEBS Lett 150: 314-318, 1982.

87. Pollock, JS, Klinghofer, V, Forstermann, U and Murad, F. Endothelial mitric oxide synthase is myristylated. FEBS Lett 309: 402-404, 1992.

88. Fraser, ID, Tavalin, SJ, Lester, LB, Langeberg, LK, Westphal, AM, Dean, RA, Marrion, NV and Scott, ID. A novel lipid-anchored A-kinase Anchoring Protein facilitates CAMP- responsive membrane events. Embo I 17: 2261-2272, 1998.

89. Silverman, $L$, Sudol, $M$ and Resh, MD. Members of the src family of nonreceptor tyrosine kinases share a common mechanism for membrane binding. Cell Growth Differ 4: 475-482, 1993.

90. Bañó, MC, Jackson, CS and Magee, Al. Pseudo-enzymatic S-acylation of a myristoylated Ves protein tyrosine kinase peptide in vitro may reflect non-enzymatic s-acylation in vivo. Biochem / 330: 723-731, 1998.

91. O'Brien, PJ and Zatz, M. Acylation of bovine rhodopsin by [3H]palmitic acid. I Bial Chem 259: 50154-5057, 1984.

92. Ross, EM. Protein modification. Palmitoylation in G-protein signalling pathways. Curr Biol 5 : 107-109, 1995 . 
93. Leventis, $R$, Juel, $G$, Knudsen, JK and Sllvilus, JR. Acyl-COA binding proteins inhibit the nonenzymic S-acylation of cysteinyl-containing peptide sequences by long-chain acylCoAs. Biochemistry $36: 5546-5553,1997$.

94. Berthia ume, L and Resh, MD. Biochemical characterization of a palmitoyl acyltransferase activity that palmitoylates myristoylated proteins. J Biol Chem 270: 22399-22405, 1995.

95. Dunphy, JT, Greentree, WK, Manahan, $\mathrm{CL}$ and Linder, ME. G-protein palmitoyltransferase activity is enriched in plasma membranes. J Biol Chem 271: 7154-7159, 1996.

96. Das, AK, Dasgupta, B, Bhattacharya, $\mathbb{R}$ and Basu, J. Purification and biochemical characterization of a protein-palmitoyl acyltransferase from human erythrocytes. I Biol Chem 272: 11021-11025, 1997.

97. Liu, L, Dudler, $T$ and Gelb, MH. Purification of a protein palmitoyltransferase that acts on H-Ras protein and on a C-terminal N-Ras peptide. J Biol Chem 271: 23269-23276, 1996.

98. Ueno, $K$ and Suzuki, Y. p260/270 expressed in embryonic abdominal leg cells of Bombyx mori can transfer palmitate to peptides. J Biol Chem 272:13519-13526, 1997.

99. Cadwallader, KA, Paterson, H, Macdonald, SG and Hancock, JF. N-teminally myristoylated Ras proteins require palmitoylation or a polybasic domain for plasma membrane localisation. Mol Cell Biol 14: 4722-4730, 1994.

100. Sachs, K, Maretzki, D, Meyer, CK and Hofmann, KP. Diffusible ligand all-trans-retinal activates opsin via a palmitoylation-dependent mechanism. J Biol Chem 275: 6189-6194, 2000.

101. Stoffell, RH, Inglese, J, Macrae, AD, Lefkowitz, RJ and Premont, RT. Palmitoylation increases the kinase activity of the $C$ protein-coupled receptor kinase, GRK6. Biochemistry 37: $16053-16059,1998$.

102. Gao, Z, Ni, Y, Szabo, G and Linden, J. Palmitoylation of the recombinant human A1 adenosine receptor: enhanced proteolysis of palmitoylation-deficient mutant receptors. Biochem / 342: 387-395, 1999 .

103. Charrin, S, Manie, S, Oualid, M, Billard, M, Boucheix, C and Rubinstein, E. Differential stability of tetraspanin/tetraspanin interaction: role of palmitoylation. FEBS Lett 516: 139144, 2002.

104. Van der Vusse, G and Reneman, RS. Integration of motor, circulatory, respiratory and metabolic control during exercise. In: Handbook of Physiology, edited by L. B. Rowell and J. T. Shepherd. Am. Phys. 5oc., 952-994, 1996

105. Kiens, B, Roemen, TH and van der Vusse, GJ. Muscular long-chain fatty acid content during graded exercise in humans. Am J Physiol 276: E352-357, 1999.

106. Bonen, A, Luiken, JJ, Arumugam, Y, Glatz, JF and Tandon, NN. Acute regulation of fatty acid uptake involves the cellular redistribution of fatty acid translocase. 1 Biol Chem 275 : $14501-14508,2000$.

107. Luiken, J, Dyck, DJ, Han, XX, Tandon, NN, Arumugam, Y, Glatz, JF and Bonen, A. Insulin induces the translocation of the fatty acid transporter FAT/CD36 to the plasma membrane. Am I Physiol Endacrinal Metabol 282: E491-E495, 2002. 
108. Luiken, Jl, Willems, J, Coort, SL, Coumans, WA, Bonen, A, Van Der Vusse, GJ and Glatz, JF. Effects of CAMP modulators on long-chain fatty-acid uptake and utilization by electrically stimulated rat cardiac myocytes. Biochem / 367: 881-887, 2002.

109. Distel, RJ, Robinson, GS and Spiegelman, BM. Fatty acid regulation of gene expression. Transcriptional and post-transcriptional mechanisms.J Biol Chem 267: 5937-5941, 1992.

110. Grimaldi, PA, Knobel, SM, Whitesell, RR and Abumrad, NA. Induction of aP2 gene expression by nonmetabolized long-chain fatty acids. Proc Natl Acad SCi U S A 89: 10930$10934,1992$.

111. Jump, DB, Clarke, SD, Thelen, $A$ and Lilimatta, $M$. Coordinate regulation of glycolytic and lipogenic gene expression by polyunsaturated fatty acids. J Lipid Res 35: 1076-1084, 1994.

112. Meunier-Durmort, C, Poirier, $\mathbf{H}$, Niot, I, Forest, $\mathbf{C}$ and Besnard, P. Up-regulation of the expression of the gene for liver fatty acid-binding protein by long-chain fatty acids. Biochem I 319 (Pt 2): 483-487, 1996.

113. Van der Lee, KA, Vork, MM, De Vries, JE, Willemsen, PH, Glatz, JF, Reneman, RS, Van der Vusse, GJ and Van Bilsen, $M$. Long-chain fatty acid-induced changes in gene expression in neonatal cardiac myocytes. J Lipid Res 41: 41-47, 2000.

114. Van der Lee, KA, Willemsen, PH $_{*}$ Samec, S, Seydoux, J, Dulloo, AG, Pelsers, MM, Glatz, JF, Van der Vusse, $G J$ and Van Bilsen, $M$. Fasting-induced changes in the expression of genes controlling substrate metabolism in the rat heart. J Lipid Res 42: 1752-1758, 2001.

115. Glatz, JF and Veerkamp, JH. Postnatal development of palmitate oxidation and mitochondrial enzyme activities in rat cardiac and skeletal muscle. Biochim Biophys Acta 711: $327-335,1982$.

116. Lopaschuk, GD, Collins-Nakai, RL and Itoi, T. Developmental changes in energy substrate use by the heart. Cardiovasc Res 26: 1172-1180, 1992.

117. Van Nieuwenhoven, FA, Verstijnen, CP, Abumrad, NA, Willemsen, PH, Van Eys, GJ, Van der Vusse, GJ and Glatz, JF. Putative membrane fatty acid translocase and cytoplasmic fatty acid-binding protein are co-expressed in rat heart and skeletal muscles. Biochem Biophys Res Commun 207: 747-752, 1995.

118. Sack, MN, Disch, DL, Rockman, HA and Kelly, DP. A role for Sp and nuclear receptor transcription factors in a cardiac hypertrophic growth program. Proc NatI Acad Sci U S A $94:$ $6438-6443,1997$.

119. Gulick, T, Ciresci, S, Caira, T, Moore, DD and Kelly, DP. The peroxisome proliferatoractivated receptor regulates mitochondrial fatty acid oxidative enzyme gene expression. Proc Natl Acad Sci US A 91: 11012-11016, 1994.

120. Gottlicher, M, Widmark, E, Li, $Q$ and Gustafsson, JA. Fatty acids activate a chimera of the clofibric acid-activated receptor and the glucocorticoid receptor. Proc Natl Acad SCI USA 89: 4653-4657, 1992.

121. Forman, BM, Chen, J and Evans, RM. Hypolipidemic drugs, polyunsaturated fatty acids, and eicosanoids are ligands for peroxisome proliferator-activated receptors alpha and delta. Proc Natl Acad Sci U S A 94: 4312-4317, 1997. 
$30 /$ Chapter 2

122. Kliewer, SA, Sundseth, S5, Jones, SA, Brown, PJ, Wisely, GB, Koble, CS, Devchand, P, Wahll, $W$, Willson, TM, Lenhard, $J M$ and Lehmann, JM. Fatty acids and eicosanoids regulate gene expression through direct interactions with peroxisome proliferatoractivated receptors alpha and gamma. Proc Nati Acad Sci U S A 94: 4318-4323, 1997. 


\section{Chapter 3}

\section{Determination of long-chain fatty acids, triacylglycerols and phospholipids by capillary gas chromatography in cardiac tissue and blood plasma of normal and diabetic rats}

Part of this chapter is published in:

Danny M. Hasselbaink, Theo H.M. Roemen, and Ger J. van der Vusse. Determination of long-chain fatty acids in heart and skeletal muscle by capillary gas chromatography. Analytica Chimica Acta 465 (2002), 351-357. 


\section{Chapter 3}

\section{Abstract}

A reliable and sensitive technique is presented to monitor the total content of non-esterified fatty acids (FA), triacylglycerols (TG), phospholipids (PL) and their relative fatty acyl composition in biological material, with special reference to rat cardiac tissue and blood plasma. The various lipid classes were separated with thin-layer chromatography. Quantification of the fatty acyl moieties was accomplished by capillary gas chromatography. Since in muscle tissue the amount of FA represents approximately $0.2 \%$ of the total esterified and non-esterified fatty acyl pool, precautions should be taken to avoid hydrolysis and/or transmethylation of esterified fatty acyl moieties during the assay procedure. In particular, attention should be paid to storage of tissue samples, disruption of tissule prior to lipid extraction and contaminants increasing the blank of the assay.

The content of FA in the cardiac ventricles of normal rats was $338 \pm 83$ nmol per gram dry weight. Streptozotocin-induced diabetes caused a significant 4.8 -fold increase in the FA content of rat cardiac ventricular tissue. The content in normal and diabetic cardiac ventricles of TG amounted to $19.6 \pm 5.3$ and $36.4 \pm 4.8 \mu \mathrm{mol}$ FA per gram dry weight, respectively. The $\mathrm{PL}$ content of normal and diabetic ventricles was comparable ( $152 \pm 14$ versus $153 \pm 9 \mu \mathrm{mol}$ FA per gram dry weight). In blood plasma, the content of nonesterified FA increased from $134 \pm 59$ to $265 \pm 88 \mu$ mol FA per litre, following 4 weeks of diabetes. The TG and PL concentrations increased from $1.67 \pm 0.39$ and $2.62 \pm 0.75 \mathrm{mmol} F A$ per litre plasma to $9.11 \pm 1.90$ and $5.01 \pm 1.11 \mathrm{mmol} F A$ per litre plasma, respectively. Both in cardiac tissue and in blood plasma, streptozotocin-induced diabetes resulted in changes in the relative fatty acyl composition of the three lipid classes studied. The changes in blood and cardiac lipid content as well as fatty acyl profiles indicate profound alterations in lipid homeostasis in the diabetic state. These alterations may contribute to the development of diabetic cardiomyopathies. 


\section{Introduction}

Non-esterified long-chain fatty acids (FA) are important substrates for energy conversion in cardiac muscle. Moreover, esterified in phospholipids (PL), they serve as building blocks of cellular membranes. Part of FA are stored inside the muscle cells as triacylglycerols (TG), while recent studies have shown that FA are also involved in intracellular signal transduction either via modulation of nuclear gene expression or through covalent binding to proteins ${ }^{1-4}$.

Since muscle tissue lacks the capability of de novo synthesis of FA, cardiac myocytes rely on the supply of FA from extracellular sources to cover their need for these substrates. FA are supplied to cardiac muscle either bound to plasma albumin (non-esterified fatty acids) or in the form of TG in the core of circulating lipoproteins ${ }^{3}$.

To investigate cardiac FA homeostasis in full detail, a sensitive and reliable analytical technique is required providing information on the tota! amount of FA and the relative fatty acyl composition (variation in chain length, number of unsaturated bonds). Although a variety of methods, including titrimetric, colorimetric, enzymatic and radiochemical analytical techniques ${ }^{5-12}$, has been employed to assess the total content of FA in biological material, capillary gas chromatography and high performance liquid chromatography (HPLC) are the first choice to analyze both the total content and the fatty acyl composition of the FA pool ${ }^{13-16}$. Since in cardiac muscle the majority of fatty acyl moieties are incorporated into the esterified lipid pool, i.e., TG and PL, special attention should be paid to tissue collection, storage and lipid extraction prior to chromatographical analysis in order to avoid any artificial elevation of the amount of FA due to hydrolysis and/or transmethylation of esterified fatty acyl moieties.

Artificial elevation of the tissue content of FA will hamper correct interpretation of findings in physiological studies aiming to unravel, for instance, the mechanisms underlying the transport of FA from the extracellular compartment to the cell interior or to disclose the biological effect of FA in the regulation of gene expression. Moreover, changes in the tissue content of FA most likely indicate profound changes in cardiac metabolism in general and in FA handling in particular. Since the metabolic fate of FA in the myocardium may depend on chain length and degree of unsaturation ${ }^{3.4}$, it is of importance to analyse the relative composition of the FA pool in this tissue. 


\section{4 | Chapter 3}

Here, a sensitive and reliable technique is presented to monitor the content and relative fatty acyl composition of FA and of the esterified lipid pools, TG and $\mathrm{PL}$, in cardiac and blood plasma. Possible pitfalls in tissue collection, storage and lipid extraction will be indicated. The application of gas capillary chromatography for the analysis of the cardiac muscle lipid content will be discussed. Finally, two examples of the analysis of the content and relative composition of FA in biological material are presented in detail: cardiac ventricular muscle and blood plasma of both normal and diabetic rats. Diabetes was studied, since evidence is accumulating that in addition to carbohydrate handling, lipid metabolism is affected in this pathological condition ${ }^{17}$.

\section{Experimental procedures}

\section{Induction of diabetes by streptozotocin}

Male Lewis rats were fed ad libitum, had free access to water, and were kept under a light-dark cycle of 12 hours ${ }^{18}$. The Institutional Animal Care and Use Committee, Maastricht University, approved the experiments.

Animals were anaesthetised with ketamine and xylazine (Eurovet, Bladel, The Netherlands), 37.5 and $7.5 \mathrm{mg} \cdot \mathrm{kg}^{-1}$, respectively, via intraperitoneal injection. Subsequently, the animals $(n=10)$ were treated with $70 \mathrm{mg} \cdot \mathrm{kg}^{-1}$ streptozotocin (STZ) in disodium citrate $(100 \mathrm{mM}, \mathrm{pH} 4.5)$ via intravenous injection in the tail vein to induce type-1 diabetes, and received a subcutaneous injection of $2.5 \mathrm{ml} 20 \%$ glucose on both lateral sides. Controls $(n=12)$ received vehicle only. STZ-treated animals were given daily a $5 \%$ glucose $(w / v)$ solution to drink. The body weight of the animals was measured prior to the injection of STZ or vehicle, and 4-5 weeks later when the animals were sacrificed (table 3.1 ).

\section{Tissue sampling}

Rats were anaesthetized with nembutal (sodium pentobarbital, $75 \mathrm{mg} \cdot \mathrm{kg}^{-1}$ body weight), and weighed (table 3.1.). After thoracotomy, $1 \mathrm{ml}$ of blood was removed from the left ventricular cavity with a syringe, rinsed with citrate. Thereafter, the heart was rapidly excised and rinsed in ice-cold $0.9 \% \mathrm{NaCl}$ solution and thereafter weighed. Then ventricles were cut from the heart, weighed (table 3.1), and frozen between the tongues of a liquid nitrogen cooled aluminium clamp ${ }^{20}$ and transferred to aluminium canisters. Blood 
was centrifuged to separate plasma from blood cells, after which plasma was transferred to glass tubes. Both plasma and the frozen tissue samples were stored at the temperature of $-80^{\circ} \mathrm{C}$.

\section{Table 3.1}

Characteristics of control and strepzotocin-treated rats

\begin{tabular}{l|l|l|}
\cline { 2 - 3 } \multicolumn{1}{c|}{} & \multicolumn{1}{c|}{ Normal } & \multicolumn{1}{c|}{ Diabetic } \\
\hline Body weight-start (gram) & $203 \pm 6.9$ & $203 \pm 8.0$ \\
Body weight-end (gram) & $310 \pm 33.3$ & $210 \pm 23.1$ \\
Ventricles (gram wet weight) & $0.9 \pm 0.1$ & $0.7 \pm 0.1$ \\
\hline
\end{tabular}

Bodyweight was measured just prior to injection of streptozotocin (diabetic) or vehicle (normal), i.e. body weight-start, and 4-5 weeks later, i.e. body weight-end. Ventricles were weighed after removing the heart from the thorax and separation from atrial, lung and fat tissue.

\section{Handling of tissue samples}

Aliquots of muscle tissue ranging from 100 to $300 \mathrm{mg}$ wet weight were pulverized in an aluminium mortar with a stainless steel pestle, both cooled in liquid nitrogen. The tissue powder was transferred to glass test tubes cooled in liquid nitrogen.

\section{Extraction of lipids}

The test tubes containing pulverized tissue were placed at $-21^{\circ} \mathrm{C}$ in a mixture of melting ice and $\mathrm{NaCl}$. The tissue powder was wetted with $2 \mathrm{ml}$ ice-cold methanol. The content of the test tubes was allowed to warm up to room temperature and weighed. According to the extraction procedure of Folch and co-workers ${ }^{19} 4 \mathrm{ml}$ chloroform was subsequently added. Butylated hydroxytoluene $(0.01 \%)$ was present in both methanol and chloroform to prevent auto-oxidation of lipids. Thereafter, heptadecanoic acid $(8 \mathrm{nmol})$ was added to correct for losses of FA during the extraction and assay procedure (recovery standard). Two hundred microlitre of blood plasma was extracted with a similar protocol. 


\section{Separation of lipids and gas chromatographical analysis}

The above mentioned lipid extracts were evaporated and subjected to onedimensional thin-layer chromatography (TLC), as described previously 3.20 . The spots corresponding with fatty acids (FA), triacylglycerols (TG) and phospholipids $(\mathrm{PL})$ were scraped from the plate and transferred into test tubes containing $0.5 \mathrm{ml}$ boron trifluoride $\left(\mathrm{BF}_{3}\right)$-methanol solution $\left(7 \% \mathrm{BF}_{3}\right)$ according to Morrison and Smith ${ }^{21}$. The fatty acyl moieties of the lipid classes were methylated at $20^{\circ} \mathrm{C}$ for $15 \mathrm{~min}$ (FA), at $100{ }^{\circ} \mathrm{C}$ for $30 \mathrm{~min}$ (TG) and at $100^{\circ} \mathrm{C}$ for $20 \mathrm{~min}$ (PL). Identification and quantification of the fatty acyl moieties in the various lipid classes were achieved with the use of a standard solution of methyl esters of fatty acids, consisting of (by their chemical notation) 14:0, 15:0, 16:0, 16:1, 17:0, 18:0, 18:1, 18:2, 18:3n6, 20:0, 20:4, 22:0, 22:4, 22:6 and 24:0. The methyl ester mixtures were analyzed by gas chromatography using a WCOT fused-silica capillary column coated with $0.2 \mu \mathrm{m}$ SP-2330 (30 m $\times 0.25 \mathrm{~mm}$ ID; Supelco, Bellefonte, PA) as described earlier ${ }^{22}$. The overall recovery of FA ranged from $90 \%$ to $105 \%$ after correction for losses during the assay procedure with the use of the recovery standard.

\section{Statistical analysis}

Data obtained from control and diabetic hearts were statistically analysed with student's $t$ test. $P$ values $<0.02$ were considered to be statistically significant.

\section{Results and Discussion}

Non-esterified long-chain fatty acids (FA) are important substrates for mammalian organs, including cardiac muscle ${ }^{3.4}$. FA not only substantially contribute to muscle oxidative energy conversion, but also serve as substrates for biologically active compounds, such as eicosanoids, and for membrane phospholipid synthesis, and act as ligands for protein factors involved in signal transduction and gene expression. To explore the precise role of FA in these physiologically important processes a sensitive and reliable analytical technique is required to analyse and quantify the content of total and individual FA in biological structures, such as cardiac muscle. The present paper focuses on a capillary gas chromatographical technique to quantify FA in muscle samples obtained from rat cardiac ventricles and blood plasma, both from control and diabetic animals. Special attention was paid 
to potential pitfalls in tissue handling and sample preparation prior to gas chromatography. The diabetic heart was included in the study since this pathological condition is associated with profound changes in FA metabolism.

\section{Sampling, storage, and handling of cardiac tissue specimens}

A time interval of warm ischemia inevitably occurs between taking a tissue specimen from cardiac muscle and freezing of the sample in liquid nitrogen. For some biochemical components, such as phosphocreatine, the time interval should be kept as short as possible, i.e., less than 2 seconds, to avoid ischemia-induced degradation of the high-energy phosphate. In contrast, we observed that no measurable change occurred in the FA content of cardiac muscle tissue with a time interval up to 15 seconds ${ }^{23}$. The deeply frozen tissue specimen can be stored up to 6 months at $-80^{\circ} \mathrm{C}$ without any change in the content of FA. In contrast, storage at $-20^{\circ} \mathrm{C}$ for 4 weeks resulted in a 30-fold increase in tissue FA content due to autolysis or (phospho)lipaseinduced hydrolysis of the endogenous esterified lipid pool ${ }^{23}$.

Thawing of the frozen tissue sample should be avoided at any rate. We observed a 2.5 -fold increase in the FA content of cardiac muscle when the temperature of the frozen tissue specimen is raised from $-80^{\circ} \mathrm{C}$ to room temperature. The increase was most likely caused by activation of endogenous (phospho)lipases in muscle cells due to the freeze-thawing procedure. Lipolysis can be prevented when the frozen tissue powder, prepared at the temperature of liquid nitrogen, is wetted with ice-cold methanol at $-21^{\circ} \mathrm{C}$ prior to lipid extraction (see Experimental procedures). Homogenization of aliquots of cardiac muscle in homogenization buffers with the use of tissue blenders should be discouraged ${ }^{24}$. In our hands, the homogenization of freshly obtained cardiac tissue in a sucrose-EDTA-TRIS buffer $(\mathrm{pH} 7.4)$, even when performed at $0-4^{\circ} \mathrm{C}$, resulted in a significant 2.8-fold increase in the tissue FA content, most likely due to activation of (phospho)lipases during homogenization.

\section{Extraction of lipids}

A variety of procedures has been introduced to extract lipids from muscle tissue. The overall requirements of any technique should be that extraction of lipids is as complete as possible and that unwanted hydrolysis and/or transmethylation of esterified fatty acyl moieties are avoided. Satisfying 
results were obtained with the extraction method originally described by Folch and co-workers ${ }^{29}$. In this procedure, pulverized tissue was treated with methanol-chloroform (1:2, by volume) at $-21^{\circ} \mathrm{C}$ (see for detail Experimental procedures). Alternatively, when the extraction procedure was applied as originally described by Dole and Meinertz ${ }^{25}$ a $140 \%$ increase in tissue FA content was observed ${ }^{26}$. It was found that the difference in outcome between the Folch and Dole methods was not caused by incomplete extraction of FA by the former method but by autolysis of endogenous lipids in the Dole extraction procedure ${ }^{26}$. When the Hagenfeldt modification of the Dole extraction method was applied ${ }^{27}$, extremely high tissue FA levels were monitored mainly due to excessive transmethylation of esterified fatty acyl moieties during the extraction procedure ${ }^{25}$.

\section{Separation and quantification of muscle tissue FA}

Prior to methylation of the fatty acyl moieties, the total lipid extract is routinely separated into the FA, TG and PL fraction using a standard TLC method ${ }^{20,22}$. The application of capillary gas chromatography allows for assessment of long-chain FA with up to 6 unsaturated carbon bonds commonly present in cardiac muscle. Figure 3.1A shows an example of the separation of the methyl esters of the standards used. In figure $3.1 \mathrm{~B}$ a typical example of a FA chromatogram of a normal rat heart is shown.

\section{Blank values}

The sensitivity of the overall technique to assess FA in muscle tissue is, among others, determined by the blank value of the assay system. Despite the fact that all glassware was carefully cleaned, all solvents of high purity analytical grade and precautions were taken to minimize contamination by finger prints, laboratory greases, etc., the blanks of the overall FA assay were on the order of $3 \mathrm{nmol}$ per sample ${ }^{23}$. To obtain a reliable estimation of the FA content in cardiac muscle tissue, the amount of FA in the extract of the biological material should be at least 2.5 -fold higher than the blank. To fulfil this requirement, at least $100 \mathrm{mg}$ of cardiac muscle or $200 \mu \mathrm{l}$ blood plasma was used for lipid extraction. 
Figure 3.1 A Chromatogram of a standard mixture of methyl esters of long-chalin FA.

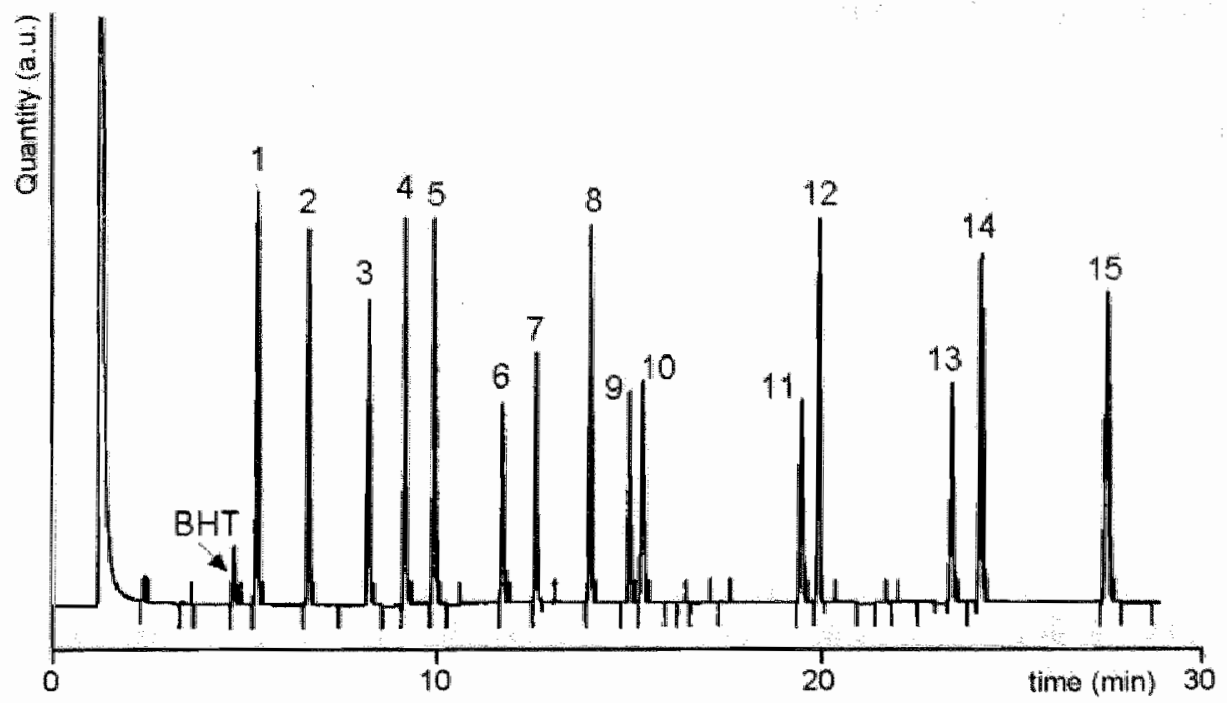

(1) $14: 0$; (2) $15: 0$; (3) $16: 0$; (4) $16: 1$; (5) $17: 0$; (6) $18: 0$; (7) $18: 1$; (8) $18: 2$; (9) $18: 3$; (10) $20: 0$; (11) $22: 0 ;$ (12) $20: 4 ;$ (13) $22: 4 ;$ (14) $24: 0$ and (15) $22: 6$ (fatty acyl moieties according to their chemical notation). BHT refers to butylated hydroxytoluene; $a . u$. refers to arbitrary units.

Figure 3.1 B Typical examples of a chromatogram of fatty acyl methylesters derived from the cardiac non-esterified FA pool in normal rat cardiac ventricles.

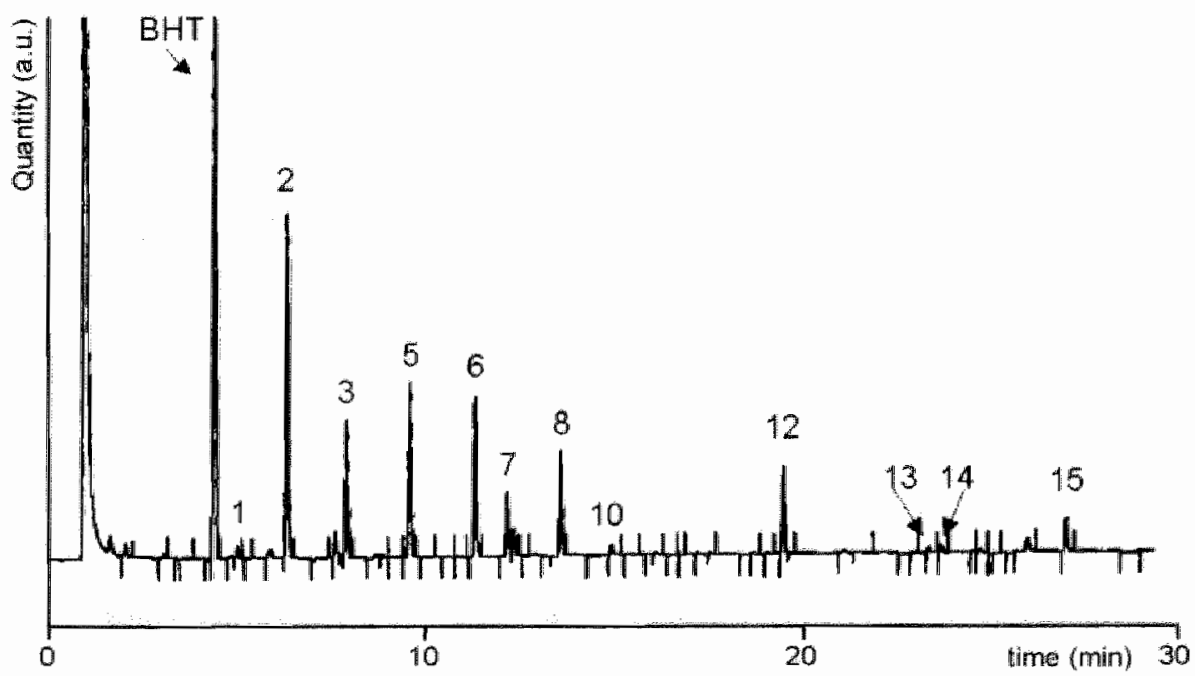

The weight of the tissue specimen used for the measurement was $115 \mathrm{mg}$ wet weight. See for details capitations to figure $3.1 \mathrm{~A}$. 
The content of $F A$ and relative fatty acid composition in rat cardiac ventricles and blood plasma

The content of FA in normal and diabetic rat ventricular tissue is shown in table $2 \mathrm{~A}$. The content of total FA was $338 \pm 83 \mathrm{nmol}$ per gram dry weight of tissue in normal rat ventricles. Since in rat cardiac tissue the dry/wet weight ratio is $4: 1$, the FA content expressed per gram wet weight is approximately $65 \mathrm{nmol} \cdot \mathrm{g}^{-1}$ wet weight. The main constituents of the FA pool in normal rat heart were palmitic (16:0), stearic (18:0), oleic (18:1), linoleic $(18: 2)$ and docosahexaenoic $(22: 6)$ acids. The total amount of fatty acyl moieties in $\mathrm{PL}$ and TG in normal rat cardiac ventricles was $152 \pm 14$ and $19.6 \pm 5.3 \mu \mathrm{mol}$ per gram dry weight, respectively, indicating that the percentage fatty acyl moieties in the non-esterified form in control rat cardiac ventricles is in the order of $0.2 \%$.

In the diabetic rat, the cardiac content of FA increased significantly 4.8-fold (table 3.2A). This finding corroborates earlier observations indicating that FA accumulate in the diabetic heart ${ }^{28,29}$, but are in contrast with previously published data by $\mathrm{Han}$ and colleagues. ${ }^{30}$, who reported a statistically insignificant $20-30 \%$ increase in cardiac FA content 6 weeks after streptozotocin treatment. In our study, all individually measured FA contributed to the increase in cardiac FA content under diabetic conditions. of interest is the observation that the relative contribution of stearic (18:0) and oleic (18:1) acid to total FA increased, but that the relative contribution of the polyunsaturated fatty acids arachidonic (20:4) and docosahexaenoic (22:6) acid decreased (table 3.2A).

The TG pool significantly expanded from $19.6 \pm 5.3$ to $36.4 \pm 5.3 \mu \mathrm{mol}$ per gram dry weight in the diabetic rat heart. Almost all fatty acyl moieties contribute to the increase in the tissue pool. Only minor changes in the relative fatty acyl composition of this lipid pool in the diabetic heart were found (table 3.2B).

The total amount of fatty acyl moieties in the PL fraction of diabetic cardiac tissue did not change as compared to non-diabetic controls (table 3.2C). With respect to the individual fatty acyl moieties in the cardiac $\mathrm{PL}$ pool, significant changes were observed in the content of 14:0, 16:1, 18:1 and 22:4, all showing a decline. In contrast, the contribution of 22:6 to the cardiac PL pool significantly increased. A number of studies have shown alterations in the relative fatty acyl profiles between control and diabetic rats in cardiac myocytes ${ }^{31-35}$ as well as in liver ${ }^{36,37}$. 


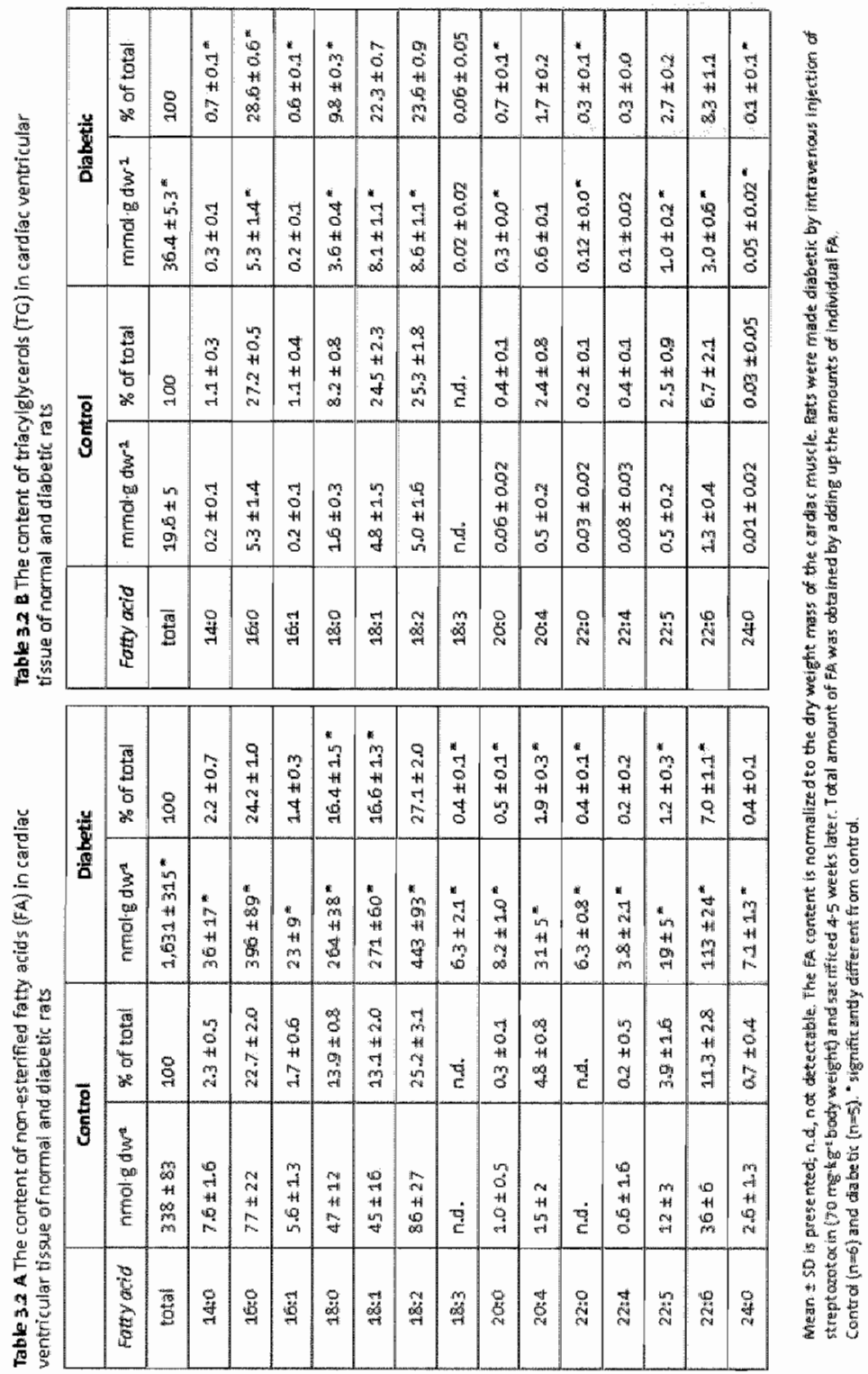



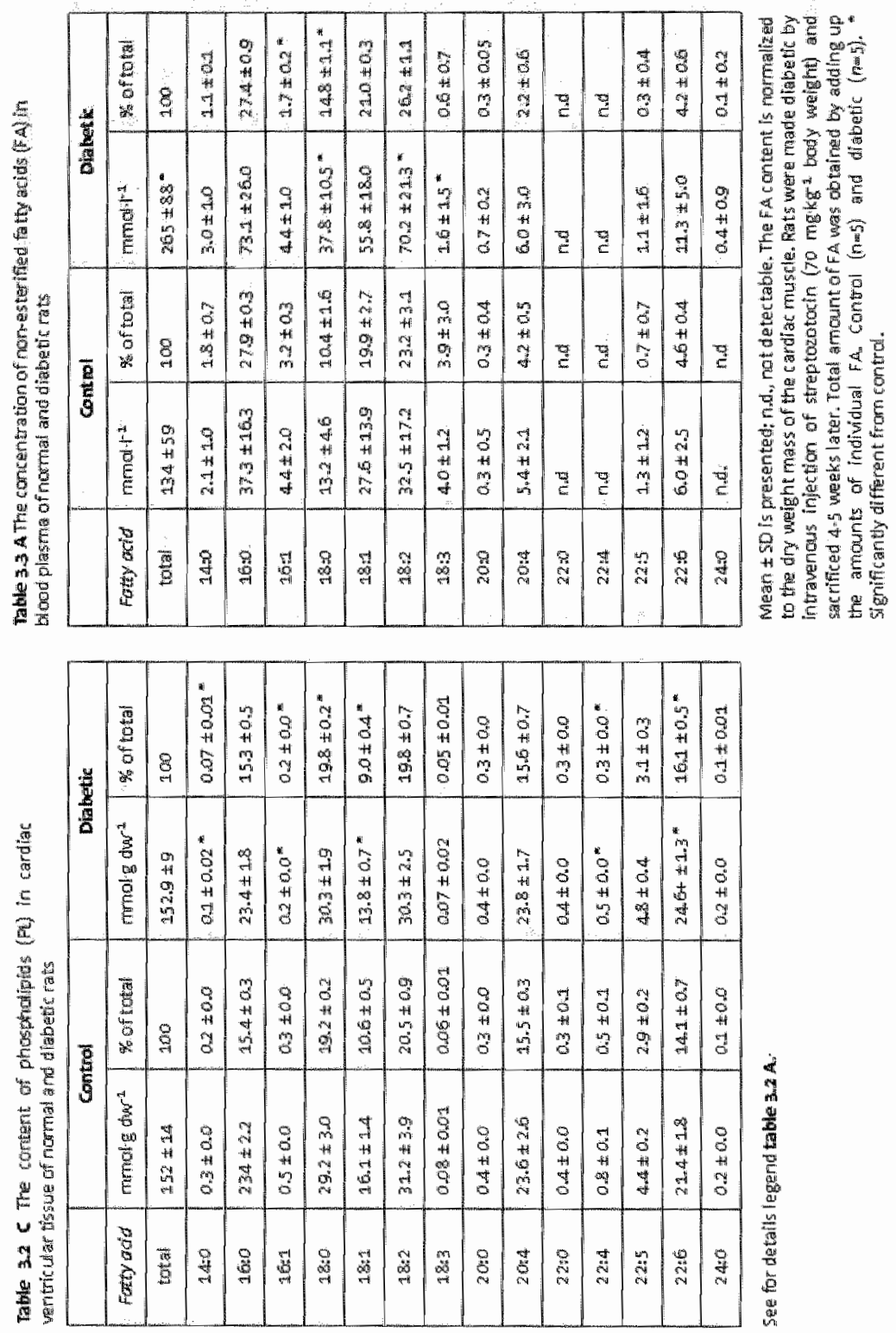
Cardiac lipid content and fatty acyl profiles $\mid 43$
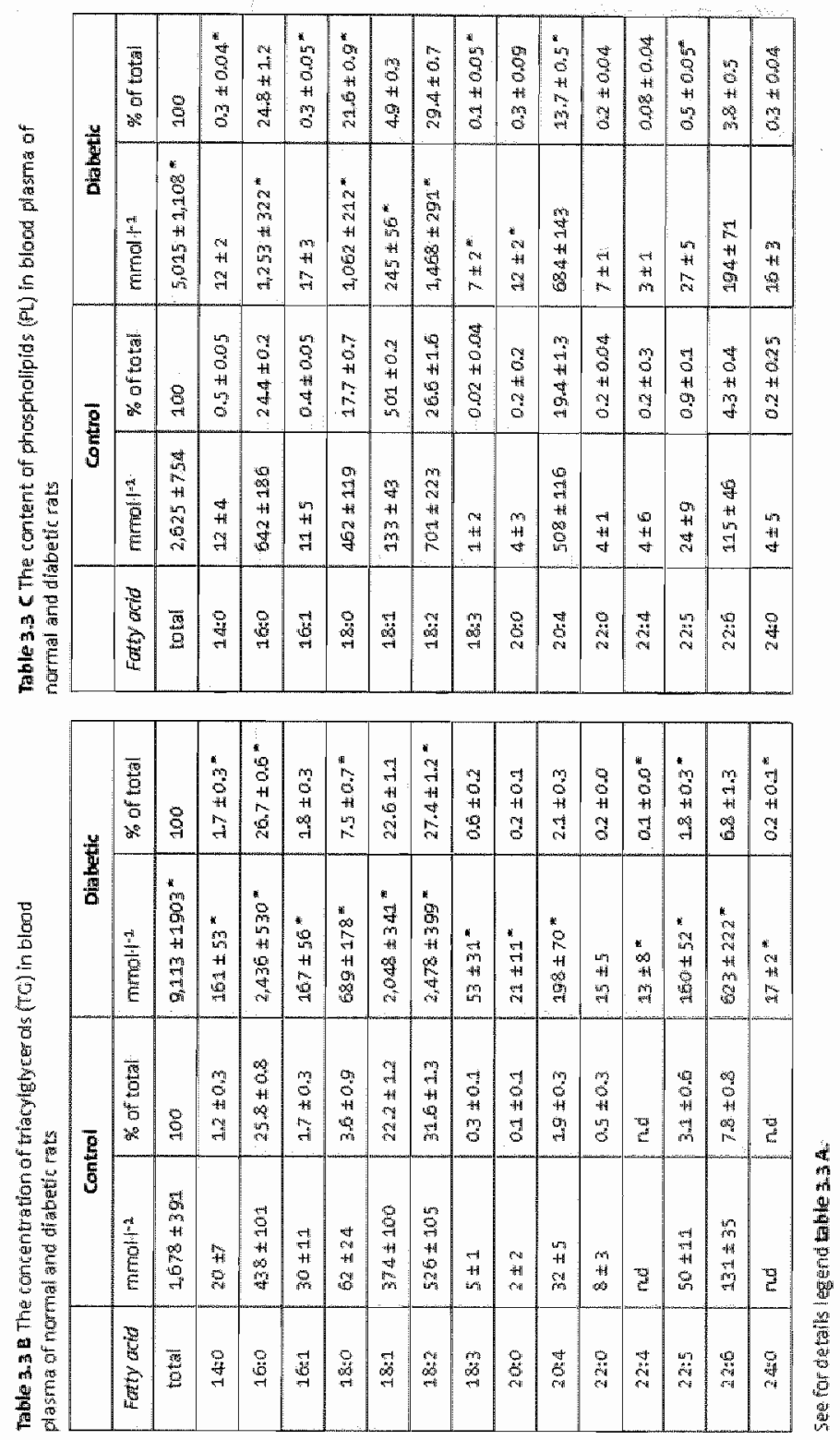
When considering the studies performed in cardiac myocytes, four studies showed a decrease in the relative amount of 20:4 ${ }^{31,33-35}$. This is in contrast with our observations concerning arachidonic acid showing no differences either in the absolute amount of 20:4 or in the relative amount (see table $3.2 \mathrm{C}$ ). Other alterations were also reported, namely an increase in the relative amount of $18: 2^{33.34}$ and $22: 6^{32,35}$ of which the latter was in accordance with our results. Similar results are also reported for the liver phospholipid fatty acid composition ${ }^{36,37}$ reporting a decline in 18:0 and 20:4 and an increase in 16:0,18:2 and 22:6. The apparent discrepancy between previous findings and the present results is incompletely understood and requires further experimentation.

Table 3.3 A, B and $C$ provides information on the content and relative fatty acyl composition of FA, TG and PL in blood plasma of normal and diabetic rats. Table $3.3 \mathrm{~A}$ indicates that the concentration of FA almost doubled in the diabetic animals. All major fatty acyl moieties contributed to this diabetes-induced increase in circulating FA. The relative composition of 18:0 increased, while the percentage of 16:1 and 20:4 significantly decreased in the FA fraction of diabetic blood plasma. The fact that the increase in cardiac FA content was about 4.8 and in blood plasma only 2 -fold suggests that FA specifically accumulates in the myocardium of the diabetic animals (figure 3.2). The precise reason is unknown, but one may speculate that in the diabetic heart uptake of FA surpasses the rate of consumption of this important substrate.

Circulating TG significantly increased from $1.68 \pm 0.39$ to $9.11 \pm 1.90$ mmol FA per litre in diabetic animals reflecting a 5.4-fold increase (table 3.3 B and figure 3.2). All major fatty acyl moieties contributed to this substantial increase (table 3.3B). The relative fatty acyl composition showed some minor changes, e.g. a relative decline in $18: 2$ and a relative increase in 16:0.

The PL concentration in blood plasma of diabetic rats increased from $2.62 \pm 0.75$ to $5.01 \pm 1.11 \mathrm{mmol}$ fatty acyl moieties per litre (table $3.3 \mathrm{C}$ and figure 3.2). All major fatty acyl moieties contributed to this increase with the exception of arachidonic acid (20:4). The relative contribution of this fatty acyl chain to the circulating PL significantly decreased from 19.4 to $13.7 \%$ (table $3.3 \mathrm{C}$ ). 
Figure 3.2 Cardiac tissue content and blood plasma concentration of FA, triacylglycerals (TC) and phospholipids (PL) in normal (C) and diabetic rats (DM).

Tissue content of latty acyl moleties
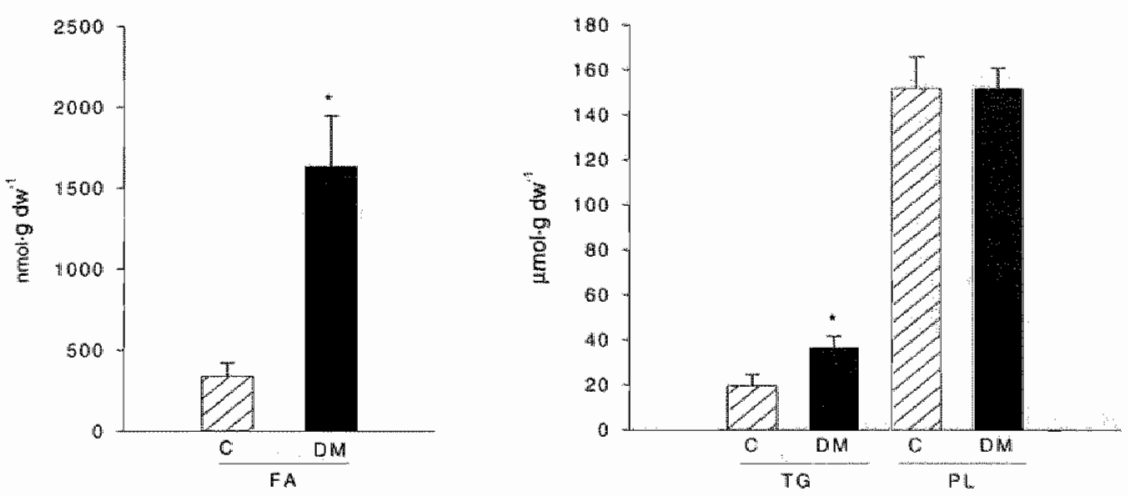

Blood plasma concentration of fatty acyl moleties
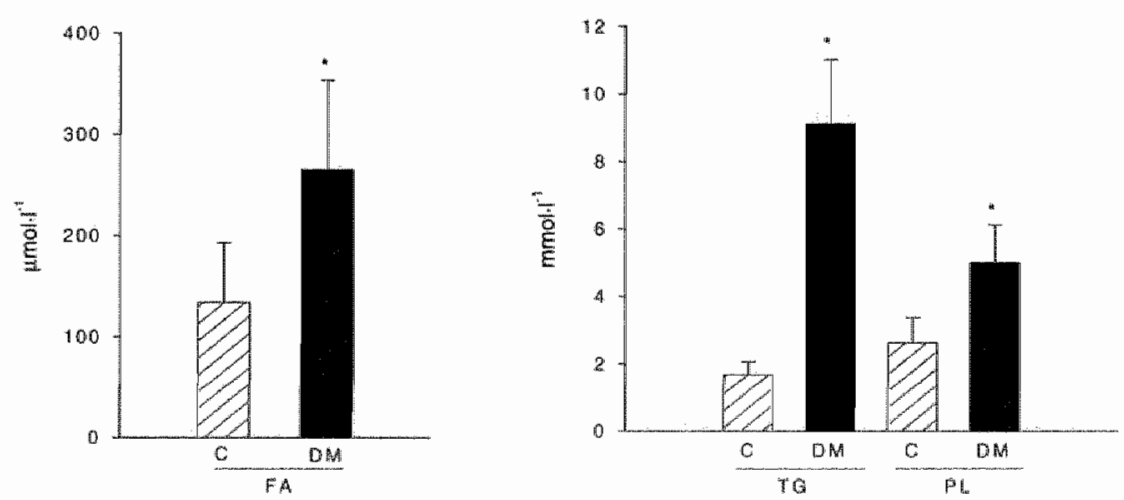

Diabetes was induced by streptozotocin treatment 4 weeks prior to sacrifice. "Indicates significantly different from corresponding control values. See tables for number of experiments

The alterations in blood plasma lipid concentration and in the relative fatty acyl composition clearly indicate that in streptozotocin-induced diabetes total body FA metabolism is profoundly changed. This is most likely caused by the almost complete lack of insulin in these animals, hampering proper control of lipid metabolism in adipose and hepatic tissue.

The collected findings in the diabetic animal, i.e. increased cardiac FA and TG contents, strongly suggest that FA handling is altered in the heart of diabetic animals in addition to overall changes in lipid homeostasis in the 
body. It is of interest to note that earlier studies have shown ${ }^{3}$ that elevated concentrations of FA are detrimental in biological structures, suggesting that changes in cardiac FA handling in the diabetic state may contribute to diabetic cardiomyopathy commonly seen in patients suffering from diabetes mellitus. Future studies should be performed to elucidate the cause(s) of FA accumulation in the diabetic heart and to explore the pathophysiological consequences of the increased FA burden on the diseased heart. These studies require reliable and sensitive analytical techniques to monitor the content and alteration therein of FA in both cardiac muscle and blood plasma. The present study offers a technique based on capillary gas chromatography to assess the content of individual and total FA in relatively small amounts of cardiac muscle tissue and in blood plasma.

\section{Conclusions}

An analytical method is discussed to determine the (non-esterified) FA content and relative fatty acyl composition in biological material with special reference to cardiac muscle and blood plasma. The fatty acyl moieties were quantified with capillary gas chromatography. Since non-esterified FA represent only a minor fraction of the total amount of fatty acyl moieties (esterified and non-esterified) in muscle tissue, i.e., on the order of $0.2 \%$, precautions should be taken to avoid hydrolysis and/or transmethylation of esterified FA during tissue sampling, storage, and lipid extraction. Comparison of cardiac tissue and blood plasma of streptozotocin-treated rats with age-matched normal rats clearly indicates that FA homeostasis is substantially affected in the diabetic animal. 


\section{References}

1. Dunphy IT and Linder ME. Signalling functions of protein palmitoylation. Biochim Biophys Acta 1436: 245-261, 1998.

2. Van Bilsen $M$, Van der Vusse $G J$ and Reneman RS. Transcriptional regulation of metabolic processes: implications for cardiac metabolism. Pflugers Arch 437: 2-14, 1998.

3. Van der Vusse GJ, Glatz JF, Stam HC and Reneman RS. Fatty acid homeostasis in the normoxic and ischemic heart. Physiol Rev 72: 881-940, 1992.

4. Van der Vusse GJ, Roemen TH and Reneman RS. Lipid metabolism in muscle. In: Handbook of Physiology. Integration of motor, circulatory, respiratory and metabolic control during exercise., edited by Rowell LB and Shepherd JT: Am. Phys. Soc., 1996, p. 952-994.

5. Duncombe WG. The colorimetric micro-determination of non-esterified fatty acids in plasma. Clin. Chim. Acta 9: 122-125, 1964.

6. Ho RJ and Meng HC. A simple and ultrasensitive method for determination of free fatty acid by radiochemicall assay. Anal Biochem 3: 426-436, 1969.

7. Kawaguchi A, Hosaka K, Kikuchi $\mathbf{T}_{\text {, }}$ Soda $\mathbf{K}$ and Okuda S. An enzymic cycling method for the determination of free fatty acids with acyl-COA synthetase and acyl-COA hydrolase. 1 Biochem (Tokyo) 94: 487-492, 1983.

8. Meinertz HP. Analytical procedures for free fatty acids. Basel: Karger, 1971.

9. Miles J, Glasscock R, Aikens J, Gerich J and Haymond M. A microfluorometric method for the determination of free fatty acids in plasma. I Lipid Res 24: 96-99, 1983.

10. Nixon $\mathrm{M}$ and $\mathrm{Chan} \mathbf{5 H}$. A simple and sensitive colorimetric method for the determination of long-chain free fatty acids in subcellular organelles. Anal Biochem 97: 403-409, 1979.

11. Trout DL, Esters EH and Friedberg SJ. Titration of free fatty acids of plasma: a study of current methods and a new modification. J. Lipid Res. 1: 199-202, 1960.

12. Turnell DC, Price CP and France MM. A 57Co-soap assay for plasma total non-esterified fatty acids compared with a gas-liquid chromatographic method. Clin Chem 26: 1879$1882,1980$.

13. Cooper MJ and Anders MW. High pressure liquid chromatography of fatty acids and lipids. J Chromatogr Sci 13: 407-411, 1975.

14. Polette A, Durand $P$, Floccard B and Blache D. A method for specific analysis of free fatty acids in biological samples by capillary gas chromatography. Anal Biochem 206: 241-245, 1992.

15. Tserng KY, Kliegman RM, Miettinen EL and Kalhan SC. A rapid, simple, and sensitive procedure for the determination of free fatty acids in plasma using glass capillary column gas-liquid chromatography. J Lipid Res 22: 852-858, 1981.

16. Van der Horst FA, Post MH, Holthuis $\mathrm{Jl}$ and Brinkman UA. Automated high-performance liquid chromatographic determination of plasma free fatty acids using on-line derivatization with 9 -bromomethylacridine based on micellar phase-transfer catallysis. $J$ Chromatogr 500: 443-452, 1990. 
17. Van der Vusse GJ, Van Bilsen M and Glatz JF. Cardiac fatty acid uptake and transport in health and disease. Cardiovasc Res 45:279-293, 2000.

18. Van der Vusse GJ and Roemen TH. Gradient of fatty acids from blood plasma to skeletal muscle in dogs. / App/ Physiol 78: 1839-1843, 1995.

19. Folch J, Lees $M$ and Stanley HS. A simple method for the isolation and purification of total lipids from animal tissues. J. Biol. Chem. 226:497-509, 1957.

20. Kiens B, Roemen TH and van der Vusse Gl. Muscular long-chain fatty acid content during graded exercise in humans. Am J Physiol 276: E352-357, 1999.

21. Morrison WR and smith LM. Preparation of fatty acid methylesters and dimethylacetals from lipids with boran fluoride-methanol. J. Lipid Res. 5: 600-608, 1964.

22. Van der Vusse Gl, Cornelussen RN, Roemen TH and Snoeckx LH. Heat stress pretreatment mitigates postischemic arachidonic acid accumulation in rat heart. Mol Cell Biochem 185: $205-211,1998$.

23. Van der Vusse GJ, Roemen TH and Reneman RS. Assessment of fatty acids in dog left ventricular myocardium. Biochim Biophys Acta 617: 347-349, 1980.

24. Kramer JM and Hulan HW. A comparison of procedures to determine free fatty acids in rat heart. JLipid Res 19: 103-106, 1978.

25. Dole VP and Meinertz HP. Microdetermination of long-chain fatty acids in plasma and tissues. J Biol Chem 235: 2595-2599, 1960.

26. Van der Vusse GJ, Roemen TH and Reneman RS. The content of non-esterified fatty acids in rat myocardial tissue. A comparison between the Dole and Folch extraction procedures. $J$ Mol Cell Cardiol 17: 527-531, 1985.

27. Hagenfeldt L. A gas chromatographic method for the determination of individual free fatty acids in plasma. Clin. Chim. Acta 13: 266-268, 1966.

28. Heyliger CE, Scarim AL, Eymer VP, Skau KA and Powell DM. Characteristics of the myocardial PM-FABP: effect of diabetes mellitus. Mol Cell Biochem 176: 281-286, 1997.

29. Nawrocki A, Gorska $M$, Wojcik B and Buslowska A. Effect of streptozotocin diabetes on fatty acid content and composition of the heart lipids in the rat. Rocz Akad Med Bialymst 44: 170-179, 1999.

30. Han X, Abendschein DR, Kelley JG and Gross RW. Diabetes-induced changes in specific lipid molecular species in rat myocardium. Biochem J 352 Pt 1: 79-89, 2000.

31. Gudbjarnason S, el-Hage AN, Whitehurst VE, Simental F and Balazs T. Reduced arachidonic acid levels in major phospholipids of heart muscle in the diabetic rat. / Mol Cell Cardiol 19: $1141-1146,1987$.

32. Horackova $M$ and Murphy MG. Effects of chronic diabetes mellitus on the electrical and contractile activities, 45Ca2+ transport, fatty acid profiles and ultrastructure of isolated rat ventricular myocytes. Pflugers Arch 411: 564-572, 1988.

33. Hu Q, Ishii E and Nakagawa Y. Differential changes in relative levels of arachidonic acid in major phospholipids from rat tissues during the progression of diabetes. I Biochem (Tokyo) 115: 405-408, 1994. 
34. Huang YS, Horrobin DF, Manku MS, Mitchell J and Ryan MA. Tissue phospholipid fatty acid composition in the diabetic rat. Lipids 19:367-370, 1984.

35. Kuwahara $Y$, Yanagishita T, Konno $\mathbf{N}$ and Katagiri $\mathrm{T}$. Changes in microsomal membrane phospholipids and fatty acids and in activities of membrane-bound enzyme in diabetic rat heart. Basic Res Cardiol 92: 214-222, 1997.

36. Burke JP and Fenton MR. Plasma and cellular zinc levels and membrane lipild composition in streptozotocin diabetic rats. Comp Biochem Physiol B 93:409-412. 1989.

37. Topping DL and Targ ME. Time-course of changes in blood glucose and ketone bodies plasma lipids and liver fatty acid composition in streptozotocin-diabetic malle rats. Horm Res 6: $129-137,1975$. 


\section{Chapter 4}

\section{Protein acylation in the cardiac muscle like cell line, H9c2.}

Part of this chapter is published in: Danny M. Hasselbaink, Theo H.M Roemen and Ger J. van der Vusse. Protein acylation in the cardiac muscle like cell line, H9C2. Mol Cell Biochem 239 (2002), 101-112 


\section{Abstract}

Besides serving as oxidizable substrates, fatty acids (FA) are involved in coand post-translational modification of proteins (protein acylation). Despite the high rate of fatty acid utilisation in the heart, information on protein acylation in cardiac muscle is scarce. To explore this subject in more detail, we used the $\mathrm{H} 9 \mathrm{C} 2$ cell line as an experimental model. After incubation with ${ }^{3} \mathrm{H}$-palmitate or ${ }^{3} \mathrm{H}$-myristate, cells were lysed and proteins precipitated, followed by extensive delipidation. The delipidated proteins were subjected to SDS-PAGE and transferred to nitro-cellulose prior to autoradiography. In addition, TLC was used to separate the various lipid classes. The first aspect we addressed was the extent of protein acylation as a function of time, relative to fatty acid incorporation into various lipid classes. Cells were incubated for $30 \mathrm{~min}, 1 \mathrm{~h}$ and $2 \mathrm{~h}$ with $100 \mu \mathrm{Ci}$ palmitate (PA, $2.3 \mathrm{nmol}$ ) or $125 \mu \mathrm{Ci}$ myristate (MA, $2.5 \mathrm{nmol})$. Palmitoylation increased from $0.48 \pm 0.25$ to $1.25 \pm 0.56 \mu \mathrm{Cimg}$ protein ${ }^{-1}$ between $30 \mathrm{~min}$ to $2 \mathrm{~h}$, while myristoylation increased from $0.25 \pm 0.12$ to $0.77 \pm 0.36 \mu \mathrm{Ci}-\mathrm{mg}$ protein ${ }^{-1}$. Furthermore, delipidated proteins subjected to autoradiography showed that a set of distinct proteins was labelled with ${ }^{3} \mathrm{H}$-palmitate. Incorporation into phospholipids (PL) increased from $40 \%$ to $60 \%$ of the total amount of radiolabelled PA or MA supplied between 30 minutes and 2 hours. Only the FA pool differed between MA and PA, with a higher FA content present after incubations with MA. Second, we investigated palmitoylation and incorporation into cellular lipids as a function of the amount of PA applied. Palmitoylation showed saturation at high PA concentrations. The percentage incorporation of ${ }^{3} \mathrm{H}-\mathrm{PA}$ in the various lipids depended on the amount of PA added: a decline in the PL pool with a concomitant increase in the size of the diacylglycerol pool at high PA concentrations. Third, inhibition of palmitoylation by cerulenin and tunicamycin was investigated. While both were able to inhibit palmitoylation, cerulenin also inhibited the incorporation of PA into various lipid classes, indicating differences in inhibitory action. 


\section{Introduction}

Under normal physiological circumstances, blood-borne fatty acids are the major energy source for cardiac muscle, their oxidation providing about $70 \%$ of the energy demand of the heart ${ }^{1}$. In addition, they serve as building blocks of cellular membranes after esterification into phospholipids or they are incorporated in the intracellular triacylglycerol pool. Recently evidence is accumulating that fatty acids also partake in signal transduction pathways ${ }^{2-5}$. In this respect, it is noteworthy that fatty acids are involved in co-and post-translational modifications of proteins.

Covalent attachment of fatty acids to proteins is now a widely recognised form of protein modification. This modification is thought to be important for protein-protein interaction, conformation, protein localisation, and activity ${ }^{6-10}$. The two most common forms of protein acylation are modifications with myristate ( $\mathrm{C} 14: 0)$ and palmitate ( $\mathrm{C} 16: 0)$, both saturated fatty acids. Despite the high rate of fatty acid utilisation in the heart, information on the physiological and pathophysiological significance of protein acylation in myocardial tissue is scarce. In 1999 Van der Vusse and Roemen showed for the first time that acylated proteins are present in normoxic cardiac tissue and were able to quantify the amount of acylated proteins in this tissue ${ }^{11}$.

Protein acylation most likely depends on a number of factors which could include the availability of exogenous fatty acids, the energy demand of the cell, and incorporation and release of fatty acids into or from the endogenous phospholipid or triacylglycerol pool. This indicates that under circumstances in which fatty acid metabolism is altered, like hypertrophy, diabetes and ischemia/reperfusion, myocardial protein acylation may be changed.

In the present study, we explored various aspects of protein acylation in cardiac muscle cells. To this end, we used the clonal rat muscle cell line $\mathrm{Hgc2}$ as a cell model of cardiac myocytes. This cell line is derived from embryonic rat heart tissue and has properties of skeletall muscle ${ }^{12}$ as well as cardiac muscle ${ }^{13,14}$. As $\mathrm{Hgc2}$ cells possess properties of cardiac muscle, they are commonly used as a model system to study metabolic properties of myocardial tissue ${ }^{15-18}$.

To further investigate protein acylation in cardiac tissue three separate goals were addressed in the present study. The first aspect of this study was to explore protein palmitoylation and myristoylation in $\mathrm{Hgc2}$ cells as function of time in relation to fatty acid incorporation into various lipid classes, such as triacylglycerol, phospholipids, and unesterified fatty acids. Second, the extent of protein palmitoylation and incorporation in cellular 
lipids as a function of the amount of exogenous palmitate applied was investigated. The final aspect was to explore whether protein acylation in the experimental cell line could be inhibited by cerulenin or tunicamycin, two known inhibitors of protein acylation ${ }^{19,20}$.

\section{Experimental procedures}

\section{Materials}

$\left[9,10-{ }^{3} \mathrm{H}\right]$ Palmitic acid $(43 \mathrm{Ci} / \mathrm{mmol})$ and $\left[9,10-{ }^{3} \mathrm{H}\right]$ myristic acid $(49 \mathrm{Ci} / \mathrm{mmol})$ were obtained from NEN Life Science Products (Boston, MA, USA). Protease inhibitor cocktail for mammalian cell extracts (P8340), palmitate, cerulenin and tunicamycin were purchased from Sigma-Aldrich (St. Louis, MO, USA). Hyperfilm ${ }^{\mathrm{m}}{ }_{-}^{3} \mathrm{H}$ was acquired from Amersham Pharmacia Biotech (Buckinghamshire, UK). The scintillation fluid Opti-fluor ${ }^{\circledR}$ was obtained from Packard Instrument Company (Meriden, CT, USA)

\section{Cell culture}

H9c2 cells were obtained from the American Type Culture Collection (ATCC CRL1446; Rockville, MD, USA) and were used from passages 22 to 25 . These cells were cultured in DMEM (Gibco BRL, Life Technologies, Gaithersburg, MD, USA) supplemented with $10 \%$ foetal calf serum (FCS, Life Technologies). Cells were plated in a $25 \mathrm{~cm}^{2}$ flask (Falcon, Becton Dickinson, Plymouth, UK) under $5 \% \mathrm{CO}_{2}$ in water saturated air. The experiments were performed two days after the cells were confluent, but still in the myoblast form.

\section{Incubations of $\mathrm{H} 9 \mathrm{C} 2 \mathrm{cells}$}

\section{I. ${ }^{3} \mathrm{H}$-labelled fatty acid incorporation as a function of time}

Prior to the start of the experiments, the $\mathrm{Hgc} 2$ cells were washed three times with PBS. Subsequently, cells were incubated for $0,0.5,1$ or 2 hours with 100 $\mu \mathrm{Ci}{ }^{3} \mathrm{H}$-labelled palmitate $(43 \mathrm{Ci} / \mathrm{mmol})$ or $125 \mu \mathrm{Ci}{ }^{3} \mathrm{H}$-labelled myristate (49 $\mathrm{Cl} / \mathrm{mmol}$ ), each dissolved in $10 \mu$ ethanol and transferred to $1 \mathrm{mI}$ DMEM per flask. At the end of the incubation, cells were washed three times with icecold PBS. Cells were lysed using $1 \mathrm{ml}$ harvesting buffer $(50 \mathrm{mM}$ Tris- $\mathrm{HCl}$ $\mathrm{pH} 7.6,150 \mathrm{mM} \mathrm{NaCl}, 5 \mathrm{mM}$ EDTA, $1 \%$ Triton X-100 (w/v), $10 \mu$ protease inhibitor cocktail) for 30 minutes on ice. Subsequently, cell remnants were 
scraped from the bottom of the flask using a rubber-policeman, after which the lysate was transferred to a glass tube.

\section{Addition of an increasing amounts of non-radiolabelled palmitate}

$\mathrm{HgC2}$ cells were incubated for $\mathrm{O}, 1$, or 2 hours with $100 \mu \mathrm{Ci}(2.3 \mathrm{nmol})$ ${ }^{3} \mathrm{H}$-labelled palmitate in the presence of $0,25,50,75$ or $150 \mathrm{nmol}$ nonradiolabelled palmitate per incubation. The mixture of labelled and non-labelled palmitate was evaporated to complete dryness under nitrogen and subsequently dissolved in $10 \mu \mathrm{l}$ ethanol and transferred to $1 \mathrm{ml}$ DMEM per flask. The same procedure as described above was performed at the end of the incubation period.

\section{Inhibitors (cerulenin and tunicamycin)}

The stock solution of cerulenin in ethanol contained $1 \mathrm{mM}$ inhibitor. An appropriate volume of the stock solution was transferred to a glass tube and dried under nitrogen. Subsequently, cerulenin was dissolved in $10 \mu$ lethanol, leading to final concentrations of 0.1 or $0.3 \mathrm{mM}$ cerulenin in $1 \mathrm{ml}$ DMEM per incubation. $\mathrm{H} 9 \mathrm{c} 2$ cells were washed three times with PBS, after which the cells were pre-incubated with medium supplemented with cerulenin for 90 minutes. At the end of the pre-incubation period, the medium was removed and cells were washed three times with PBS. Medium supplemented with $100 \mu \mathrm{Ci}{ }^{3} \mathrm{H}$-labelled palmitate per $\mathrm{ml}$ was added to the cells for up to 30 and 60 minutes. The same procedure as described above was performed at the end of the incubation period.

A stock solution of $1 \mathrm{mg} \cdot \mathrm{ml}^{-1}$ tunicamycin in $10 \mathrm{mM} \mathrm{NaOH}$ was prepared. $\mathrm{Hgc2}$ cells were incubated with $100 \mu \mathrm{Ci}{ }^{3} \mathrm{H}$-labelled palmitate in combination with 0,10 or $20 \mu \mathrm{g} \cdot \mathrm{ml}^{-1}$ tunicamycin per $1 \mathrm{ml}$ DMEM for up to 30 or 60 minutes. Addition of the tunicamycin solution to the medium did not lead to an alteration of the $\mathrm{pH}$ (data not shown). The same procedure as described above was performed at the end of the incubation period.

\section{Protein precipitation}

Proteins were precipitated according to Wessel and Flügge ${ }^{21}$. In short, cell lysates were subjected to the following protocol. To the lysate, $4 \mathrm{ml}$ methanol was added and the samples were vortexed and centrifuged ( 1 minute, $4500 \mathrm{~g}, 20^{\circ} \mathrm{C}$ ). Then $2 \mathrm{ml}$ chloroform was added after which the samples were vortexed and centrifuged again ( 1 minute, $4500 \mathrm{~g}$ ). For phase 
separation, $3 \mathrm{ml}$ millio water was added, and the samples were vortexed vigorously and centrifuged for 5 minutes at $4500 \mathrm{~g}$. The upper phase was carefully removed and transferred to a glass tube. A further $3 \mathrm{ml}$ methanol was added to the lower chloroform phase and interphase. The sample was vortexed and centrifuged once more $\left(15\right.$ minutes, $\left.4500 \mathrm{~g}, 20^{\circ} \mathrm{C}\right)$ to precipitate the protein. The supernatant was removed and combined with the earlier obtained upper phase. The precipitated proteins were subsequently subjected to extensive delipidation to remove all noncovalently bound fatty acids.

\section{Removal of non-covalently bound fatty acids}

The method for extraction of non-covalently bound fatty acids was adapted from Muszbek and Laposata ${ }^{22}$. The precipitated proteins were extracted with $3 \mathrm{ml}$ chloroform/methanol (2:1). The sample was vigorously vortexed and incubated for 30 minutes at room temperature. To pellet the protein precipitates, $3 \mathrm{ml}$ methanol was added to the sample and centrifuged (15 minutes, $4500 \mathrm{~g}, 20^{\circ} \mathrm{C}$ ). The protein precipitate was extracted twice more with chloroform/methanol (2:1) and thereafter twice with chloroform/methanol (1:2). After the last extraction, the precipitated protein fraction contained no radioactivity removable by lipid extracting solvents. The supernatant of each extraction step was collected and combined with the previously obtained supernatants in a glass tube. The protein precipitates as well as the combined lipid extracts were dried completely under nitrogen.

\section{Separation of lipid classes by thin layer chromatography (TLC)}

The dried lipid extract was dissolved in $2 \mathrm{ml}$ chloroform/methanol (2:1). On TLC plate coated with a $0.25 \mathrm{~mm}$ thick layer of silica gel 60 (Merck), $10 \mu \mathrm{l}$ of the extract was applied. The lipid spots were pre-developed in chloroform $/$ methanol/millio water/acetic acid (10:10:1:1, by volume) until the liquid front reached a level of $1 \mathrm{~cm}$ above the site of application of the lipid extract ${ }^{23}, 24$. After the plate was dried under nitrogen, the lipid spots were developed in petroleum ether/diethylether/acetic acid (120:25:1.5, by volume). After development the plate was dried under nitrogen and measured using Tracemaster 20 with detector LB2821 (Berthold, Benelux Analytical instruments, Vilvoorde, Belgium). Lipid spot were scraped from the plate and counted with a scintillation counter. 


\section{Total lipid content of $\mathrm{H} 9 \mathrm{C} 2 \mathrm{cells}$}

The technique for quantitative analysis of fatty acyl moieties present in the various lipid classes are based on analytical techniques published earlier by Roemen and co-workers ${ }^{23}$. In short, $\mathrm{H} 9 \mathrm{c} 2$ cells were incubated with 77.3 nmol non-labelled palmitate for $0,0.5,1$, and 2 hours. Subsequently, cells were scraped from the plate with $2 \mathrm{ml}$ suprasolve methanol using a rubberpoliceman and transferred to a glass tube. Thereafter $4 \mathrm{ml}$ chloroform was added. At this point, a mixture of heptadecanoic acid $(8 \mathrm{nmol})$ and triheptadecanoyl glycerol (125 nmol) was added to correct for losses during extraction and assay procedures. The chloroform/methanol $(2: 1$, by volume) extraction step was repeated two times. Subsequently, the extracts were combined, dried under a stream of nitrogen and the lipid residue was taken up in $150 \mu \mathrm{l}$ chloroform/methanol (2:1, by volume). Thereafter the concentrated lipid extract was subjected to the same TLC procedure as described above. The lipid moieties were made visible with rhodamine B-6G and fluorescein in methanol. The lipid spots corresponding to unesterified FA, triacylglycerols, and phospholipids were scraped from the plate and transmethylated according to Morrison and Smith ${ }^{25}$. Subsequently, the methylesters were subtracted with pentane and after evaporation of pentane, dissolved in 2,2,4-trimethylpentane containing appropriate amounts of the methyl ester of pentadecanoic acid (recovery standard). Quantification of the fatty acyl moieties in the various lipid classes were achieved with the use of a standard solution of methyl esters of fatty acids, composed of (by their chemical notation) 14:0, 16:0, 16:1, 18:0, 18:1, 18:2, $18: 3 n-3,18: 3 n-6,20: 0,20: 4,22: 0,22: 4,22: 6,24: 0$ and $24: 1$. The methyl esters were analysed by gas chromatography using a fused-silica capillary column coated with $0.2 \mu \mathrm{m}$ SP-2330 ( $30 \times 0.25 \mathrm{~mm}$ ID; Supelco, Bellefonte, PA, USA). The starting temperature of the column was $150^{\circ} \mathrm{C}$ for 2 minutes and the column temperature was increased to $190^{\circ} \mathrm{C}$ at $4^{\circ} \mathrm{C}$-minute -1 . Thereafter, temperature was kept at $190^{\circ} \mathrm{C}$ for 10 minutes and subsequently increased to $210^{\circ} \mathrm{C}$ at a rate of $10^{\circ} \mathrm{C} \cdot$ minute ${ }^{-1}$. The helium flow rate was $20 \mathrm{~cm} \cdot \mathrm{s}^{-1}$. Detection was accomplished by flame ionisation.

\section{Protein separation and autoradiography}

Delipidated protein was solubilized in $90 \mu$ lysis buffer (40mM Tris, $\mathrm{pH7.4}$, $2 \%$ SDS, $1 \mathrm{mM}$ EDTA). A single aliquot of $10 \mu \mathrm{l}$ was used to determine the protein content and the incorporated ${ }^{3} \mathrm{H}$-labelled fatty acids in the sample. To the remaining fraction, $20 \mu \mathrm{l}$ sample buffer was added $10.5 \mathrm{mM} \mathrm{Tris-HCl}$, $20 \%$ glycerol $(v / v), 4 \%$ SDS $(w / v), 0.02 \%$ bromophenol blue, millio, 
$58 /$ Chapter 4

$2.5 \%(\beta$-mercapto-ethanol $(v / v))$. Proteins were separated by SDS-PAGE in $4-15 \%$ gradient gels according to Laemmli ${ }^{26}$. Subsequently, proteins were blotted onto nitro-cellulose (pore size $0.45 \mathrm{\mu m}$ ) using the Electrophoresis System from Bio-Rad Laboratories (Hercules, CA, USA). The blots were dried

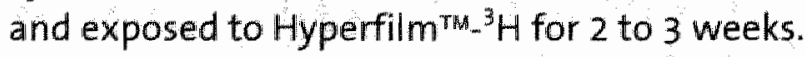

\section{Quantification}

For quantification analysis, autoradiography films were scanned with the Fluor-5 imaging system (Bio-Rad Laboratories) and images were analysed with the program Quantity One (Bio-Rad Laboratories) to obtain densitometric values. For each band detected with the Quantity One software, the optical density $\times \mathrm{mm}$ was measured and from this the relative quantity of each detected band was assessed.

\section{Miscellaneous techniques}

Total protein content of $\mathrm{H} 9 \mathrm{C} 2$ cells was quantified using the Micro BCA protein assay kit (Pierce, Rockford, IL, USA) with BSA as standard. Radioactivity was counted in a liquid scintillation counter.

\section{Statistical analysis}

Results are expressed as the mean \pm SD for at least four data points, unless otherwise indicated. Analysis of experiments with two groups was performed with Two-sample Student's $t$ tests. Differences between various groups at one time point were assessed using a one-way ANOVA. For all analyses, the level of significance was set at 0.05 . 


\section{Results}

Protein acylation and ${ }^{3} \mathrm{H}$-fatty acid incorporation in cellular lipids as a function of time

The amount of non-extractable radioactivity in the protein fraction after incubation with either ${ }^{3} \mathrm{H}$-palmitate or ${ }^{3} \mathrm{H}$-myristate, was determined for several time points over a period of up to 2 hours. Figure 4.1 shows that the amount of activity bound to the protein fraction after incubation with ${ }^{3} \mathrm{H}$-palmitate increased in a non-linear fashion to $1.25 \pm 0.56 \mu \mathrm{Ci}$ per $\mathrm{mg}$ protein. The time-related pattern of the covalent attachment of ${ }^{3} \mathrm{H}$-myristate to proteins showed a more linear relationship. The amount of covalently bound ${ }^{3} \mathrm{H}$-myristate increased from 0.36 to $0.77 \mu \mathrm{Cl} \cdot \mathrm{mg}$ protein ${ }^{-1}$ after 1 and 2 hours, respectively. Over $99 \%$ of the labelled fatty acids present in the lysate were found in the combined lipid pools, while less than 0.3 percent became covalently attached to proteins.

Figure 4.1 Protein acylation as function of incubation time

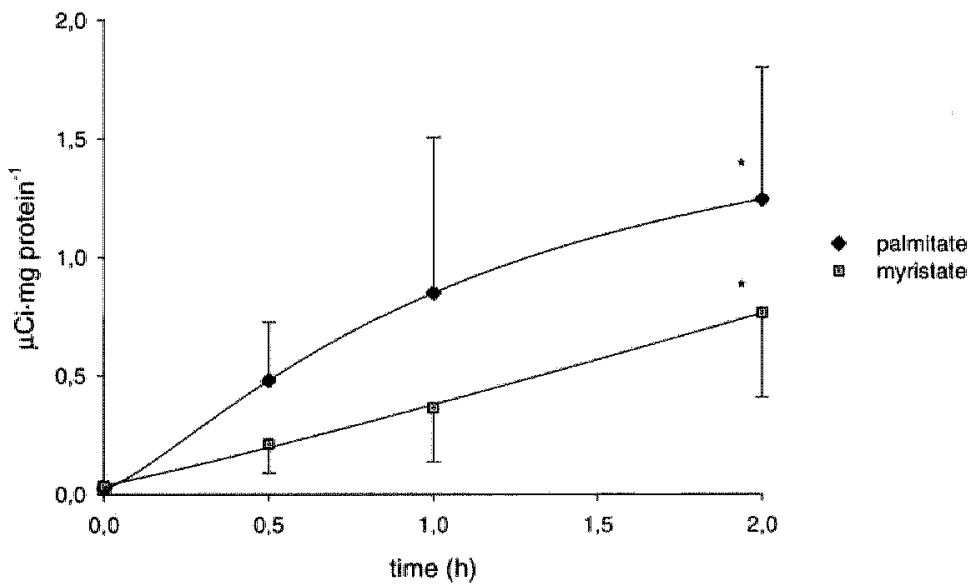

$\mathrm{H} 9 \mathrm{C2}$ cells were incubated for up to 2 hours with $100 \mu \mathrm{Ci} \cdot \mathrm{m}^{-13} \mathrm{H}$-palmitate or $125 \mu \mathrm{Ci} \cdot \mathrm{ml}^{-1 .}$ ${ }^{3}$ H-myristate. Data are mean \pm SD $(n=6)_{i}^{*}$ p $<0.05,0.5$ hour versus 2 hours

Figures 4.2 and 4.3 show that both palmitate and myristate were preferentially incorporated in the phospholipid (PL) pool, increasing from $40 \%$ of the total activity found in this lipid fraction after 30 minutes to $60 \%$ after 2 hours. Furthermore, there was a slight difference between the distribution over diacylglycerol (DG) and fatty acid (FA) pools when PA and MA are compared. Although not significant, incubations with ${ }^{3} \mathrm{H}$-myristate 
60 Chapter 4

led to a higher level of this fatty acid in the cellular non-esterified fatty acid pool when compared with ${ }^{3} \mathrm{H}$-palmitate, while after $0.5 \mathrm{~h}$ significantly less ${ }^{3} \mathrm{H}$-myristate was incorporated in the DG pool.

Figure 4.2 ${ }^{3} \mathrm{H}$-palmitate incorporation in various lipid classes in $\mathrm{Hgc2}$ cells

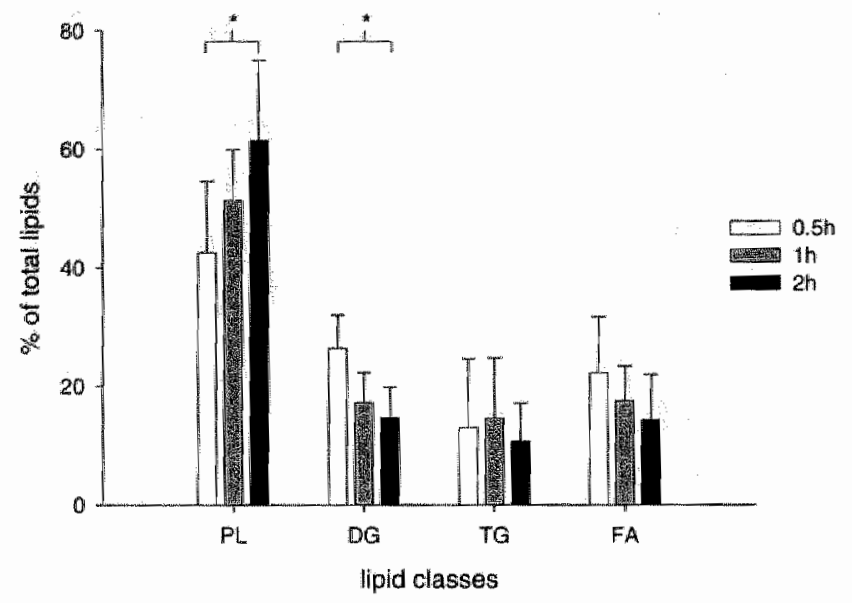

$\mathrm{H} 9 \mathrm{C2}$ cells were incubated with $100 \mu \mathrm{Ci} \cdot \mathrm{ml}^{-1}{ }^{3} \mathrm{H}$-palmitate for up to 2 hours. PL-phospolipids, DG-diacylglycerols, TG-triacylglycerols, FA-unesterified fatty acids.

Data are mean $\pm S D(n=4) ; * 0<0.05,0.5$ hour versus 2 hours.

Figure. 4.3 ${ }^{3} \mathrm{H}$-myristate incorporation in various lipid classes in $\mathrm{H} 9 \mathrm{C2}$ cells

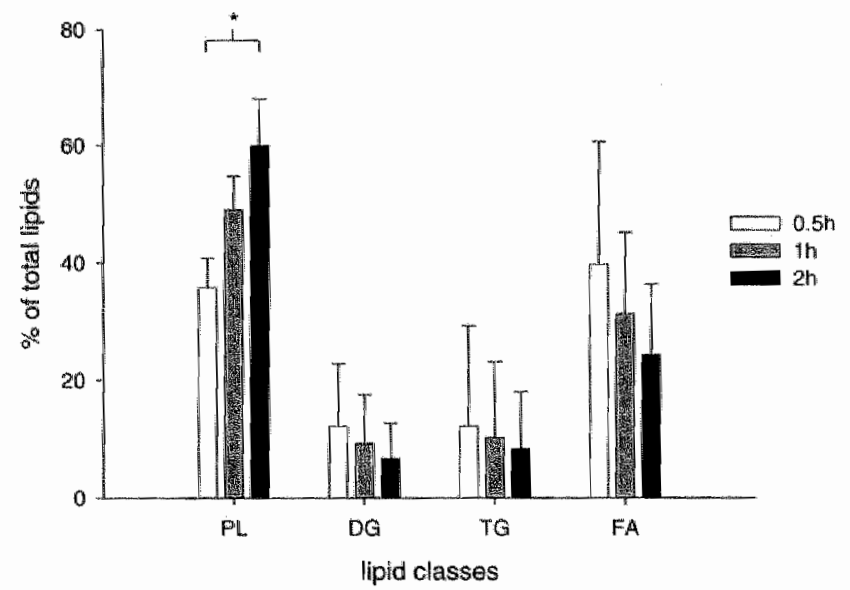

$\mathrm{H} 9 \mathrm{cz}$ cells were incubated with $125 \mu \mathrm{Ci} \cdot \mathrm{ml}^{-1}{ }^{3} \mathrm{H}$-myristate for up to 2 hours.

$\mathrm{PL}$-phospolipids, DG-diacylglycerols, TG-triacylglycerols, FA-unesterified fatty acids.

Data are mean \pm SD $(n=4) ; " p<0.05,0.5$ hour versus 2 hours. 


\section{Autoradiography of ${ }^{3} \mathrm{H}$-palmitate labelled proteins}

Figure 4.4 illustrates that routine incubation of $\mathrm{Hgc2}$ cells with ${ }^{3} \mathrm{H}$-labelled palmitate resulted in a pattern in which distinct proteins could be identified. Comparison of a coomassie blue stained gel (panel-A) with the autoradiogram (panel-B) shows that only a selected number of proteins present in the $\mathrm{H} 9 \mathrm{C2}$ cell became modified by covalent attachment of ${ }^{3} \mathrm{H}$-palmitate.

Figure 4.4 A representative Coomassie Blue staining of $\mathrm{H} 9 \mathrm{C2}$ proteins and a autoradiogram of $\mathrm{Hgc} 2$ cells incubated with ${ }^{3} \mathrm{H}$-palmitate for $0.5,1$ and 2 hours.

$\boldsymbol{A}$

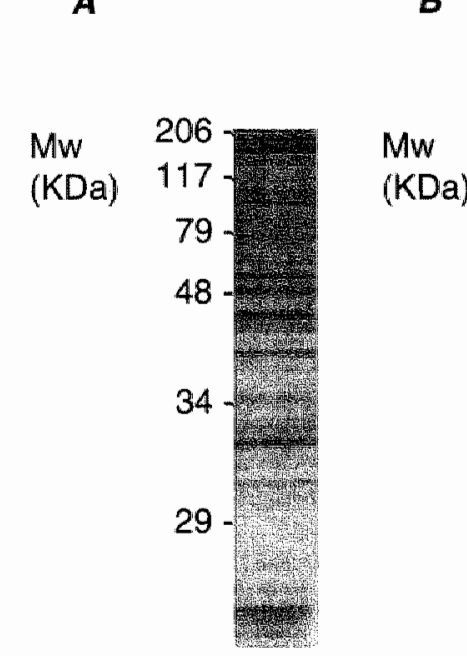

$B$
$\mathrm{H} 9 \mathrm{c} 2$

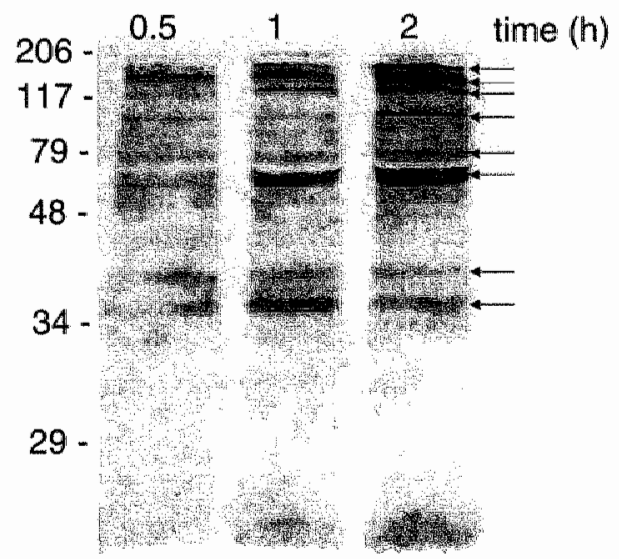

$\mathrm{H} 9 \mathrm{CZ}$ cells were labelled with $100 \mu \mathrm{Ci} \cdot \mathrm{ml}{ }^{-1}{ }^{3} \mathrm{H}$-palmitate for up to 2 hours. Panel-A shows a Coomassie Blue staining of a $12 \%$ gel and Panel-B shows an autoradiogram obtained after separation of $\mathrm{H} 9 \mathrm{C} 2$ proteins using a $12 \%$ gel, blotted onto nitro-cellullose, and subjected to 3 weeks exposure to a film. Arrows indicate bands quantified as summarised in table 4.1.

Furthermore, it can be seen from figure 4.4, panel B that the density of several distinct proteins varied in time. The variation in relative quantity of the most prominent bands is shown in table 4.1. It can be seen that, for instance, the relative quantity of the $78 \mathrm{kDa}$ band gradually increased in time, while the quantity of the 198 and $123 \mathrm{kDa}$ bands remained stable. 
Table 4.1 Quantification of covalently bound ${ }^{3} \mathrm{H}$-palmitate to a distinct set of proteins in $\mathrm{H} 9 \mathrm{C2}$ cells

\begin{tabular}{c|ccc}
\hline & \multicolumn{3}{|c}{ incubation time (h) } \\
\hline \multirow{2}{*}{ distinct proteins } & 0.5 & 1 & 2 \\
Mw (kDa) & & relative quantity $(\%)$ & \\
\cline { 2 - 4 } 194 & 7.1 & 4.0 & 4.5 \\
168 & 3.4 & 3.3 & 3.4 \\
123 & 2.6 & 2.1 & 2.9 \\
93 & 6.9 & 4.3 & 4.4 \\
78 & 5.6 & 6.4 & 7.2 \\
69 & 4.9 & 4.0 & 4.2 \\
4.2 & 5.0 & 7.9 & 3.6 \\
36 & 4.8 & 6.5 & 5.3 \\
\hline
\end{tabular}

The autoradiogram wals scanned with the Fluor-S imaging system (Biorad) and analysed with the software program Quantity-One (Biorad). The values shown represent the relative quantity (\%) of the OD $\times \mathrm{mm}$ of each selected band, after background subtraction. The sum of OD $\times \mathrm{mm}$ of all detectable bands is set at $100 \%$. Only the most prominent bands with a relative quantity $>2 \%$ are shown.

The effect of the concentration of exogenous palmitate on palmitoylation

To study whether protein acylation could be saturated, we incubated $\mathrm{H} 9 \mathrm{C2}$ cells with $100 \mu \mathrm{Ci}{ }^{3} \mathrm{H}$-palmitate $(2.3 \mathrm{nmol})$ in the presence of increasing amounts of non-labelled palmitate, varying from o nmol palmitate to 150 nmol palmitate. Table 4.2 shows the metabolic fate of the ${ }^{3} \mathrm{H}$-fatty acids supplied with increasing concentrations of non-radiolabelled palmitate. The amount of radioactive label present in the lysate diminished with increasing concentrations of non-radiolabelled palmitate. At the same time, the amount of radioactive label present in the medium at the end of the incubation period was enlarged.

Taking into account the differences in specific activity, the amount of $\mathrm{nmol}$ palmitate per incubation can be calculated. Figure 4.5 shows that palmitoylation of cellular proteins was not only time dependent (as already shown in figure 4.1) but more importantly, that the amount of fatty acids that became covalently attached to proteins increased with the supplied 
amount of palmitate. At increasing concentrations of exogenously supplied palmitate, the amount of palmitate incorporated in the protein fraction levelled off at approximately $0.35 \mathrm{nmol} \cdot \mathrm{mg}_{\text {protein }}{ }^{-1}$.

Table 4.2 Quantitative distribution of ${ }^{3} \mathrm{H}$-palmitate with increasing concentrations of non-labelled palmitate

\begin{tabular}{|c|c|c|c|c|c|}
\hline $\begin{array}{c}\text { amount of } \\
\text { polmitate ( } \mathrm{nmol} \text { ) }\end{array}$ & 2.3 & 27.3 & 52.3 & 77.3 & 152.3 \\
\hline fraction & \multicolumn{5}{|c|}{ amount of recovered ${ }^{3} \mathrm{H}$-palmitate $(\mu \mathrm{Ci})$} \\
\hline medium & $11.5 \pm 0.9$ & $16.2 \pm 2.1$ & $41.5 \pm 9.3$ & $43.5 \pm 4.6$ & $58.9 \pm 6.8$ \\
\hline lysate & $91.1 \pm 11.6$ & $74.6 \pm 9.6$ & $72.6 \pm 12.8$ & $67.5 \pm 8.3$ & $54.4 \pm 9.9$ \\
\hline lipid & $87.3 \pm 2.3$ & $77.5 \pm 3.5$ & $66.9 \pm 1.9$ & $60.7 \pm 1.1$ & $52.8 \pm 24$ \\
\hline protein & $0.23 \pm 0.04$ & $0.11 \pm 0.01$ & $0.09 \pm 0.01$ & $0.07 \pm 0.01$ & $0.05 \pm 0.01$ \\
\hline
\end{tabular}

$\mathrm{H} 9 \mathrm{C} 2$ cells were incubated with $100 \mu \mathrm{Ci}{ }^{3} \mathrm{H}$-palmitate in the presence of increasing amounts. of non-labelled palmitate. Aliquots were taken from the medium at the end of the incubation period. Furthermore, aliquots were taken from the lysate, lipid fraction, and protein fraction. The lipid fraction includes the phospholipids, diacylglycerols, triacylglycerols, and non-esterified fatty acids. The values shown represent the mean \pm SD of ${ }^{3} \mathrm{H}$-label recovered in each fraction in $\mu \mathrm{Ci} .(n=4)$

Figure 4.6 shows that the amount of palmitate present in the incubation medium also influenced the amount of palmitate incorporated into the several lipid fractions. Panel-A shows that increasing amounts of palmitate led to an increased incorporation of palmitate into the PL, DG and TG pool. Panel-B shows that the amount of fatty acid, which remained unesterified in the intracellular lipid pool, increased linearly with the amount of exogenously supplied palmitate.

In parallel experiments, $\mathrm{H} 9 \mathrm{C2}$ cells were incubated with $77.3 \mathrm{nmol}$ non-labelled palmitate after which the cellular content of PL, TG, and FA was measured by capillary gas chromatography (figure 4.7, panels $A, C$ and $E$ ). It is shown that the amount of fatty acyl moieties present in the PL pool remained in the order of $220 \mathrm{nmol}$ per incubation. The amount of unlabelled palmitate present in the PL pool remained relatively stable, varying from 47.5 to $53.9 \mathrm{nmol}$ between $\mathrm{O}$ and 2 hours, respectively (panel-A). 
Figure 4.5 Protein palmitoylation as function of the amount of palmitate applied

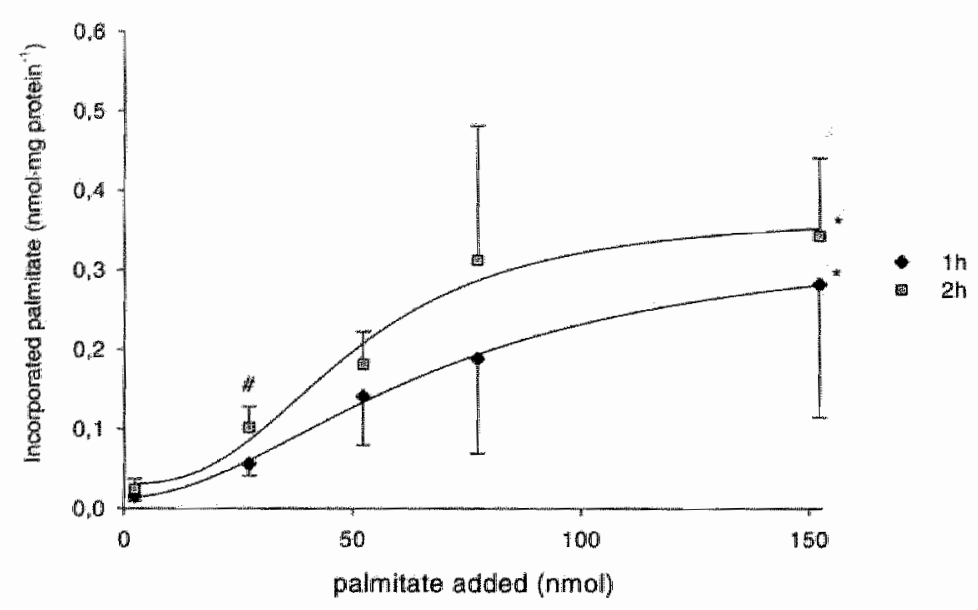

$\mathrm{H} 9 \mathrm{C2}$ cells were incubated with $100 \mu \mathrm{Cl}{ }^{3} \mathrm{H}$-palmitate in the presence of increasing amounts of non-labelled palmitate, varying from to to $150 \mathrm{nmol}$. The amount (nmol-incubation ${ }^{-1}$ ) of covalently attached palmitate per $\mathrm{mg}$ protein was calculated by taking into account the specific activity of radiolabelled palmitate for each condition. Data are mean \pm SD $(n=4)$; * p<0.05, $2.3 \mathrm{nmol}$ and $27.3 \mathrm{nmol}$ versus $152.3 \mathrm{nmol}$ \# $\mathrm{p}<0.05,1$ hourversus 2 hours.

Furthermore, the total fatty acid content present in the TG pool was raised from 7.4 to 14.0 nmol per incubation after 0 and 2 hours, respectively. The amount of unlabelled palmitate increased from 1.9 to $6.3 \mathrm{nmol}$ between 0 and 2 hours (Panel-C). The fatty acyl moieties in the FA pool increased from 2.7 to $12.8 \mathrm{nmol}$ per incubation after 0 and 2 hours, respectively. The amount of palmitate in the FA pool first increased from 1.1 to $8.9 \mathrm{nmol}$ palmitate after 0 and 1 hour, respectively, and stabilised thereafter (Panel-E). These results were compared with the amounts of palmitate incorporated per incubation of $\mathrm{HgC2}$ cells in the presence of $77.3 \mathrm{nmol}(75 \mathrm{nmol} \mathrm{non-labelled+}$ $2.3 \mathrm{nmol}{ }^{3} \mathrm{H}$-labelled) palmitate after taking into account specific activity (figure 4.7, panels B, D and F). The amount of palmitate incorporated into the PL pool increased from 7 to $12.5 \mathrm{nmol}$ after 1 and 2 hours, respectively (panel-B). Panel-D shows that the amount of palmitate incorporated into the TG pool increased from 4.1 to $6.1 \mathrm{nmol}$ after 1 and 2 hours, respectively. The amount of palmitate remaining in the lipid pool as unesterified palmitate remained stable, varying from 19.0 to $21.1 \mathrm{nmol}$ after 1 and 2 hours, respectively (panel-F). 
Fig. 4.6 Effect of the amount of non-labelled palmitate on the rate of palmitate incorporation in lipid classes
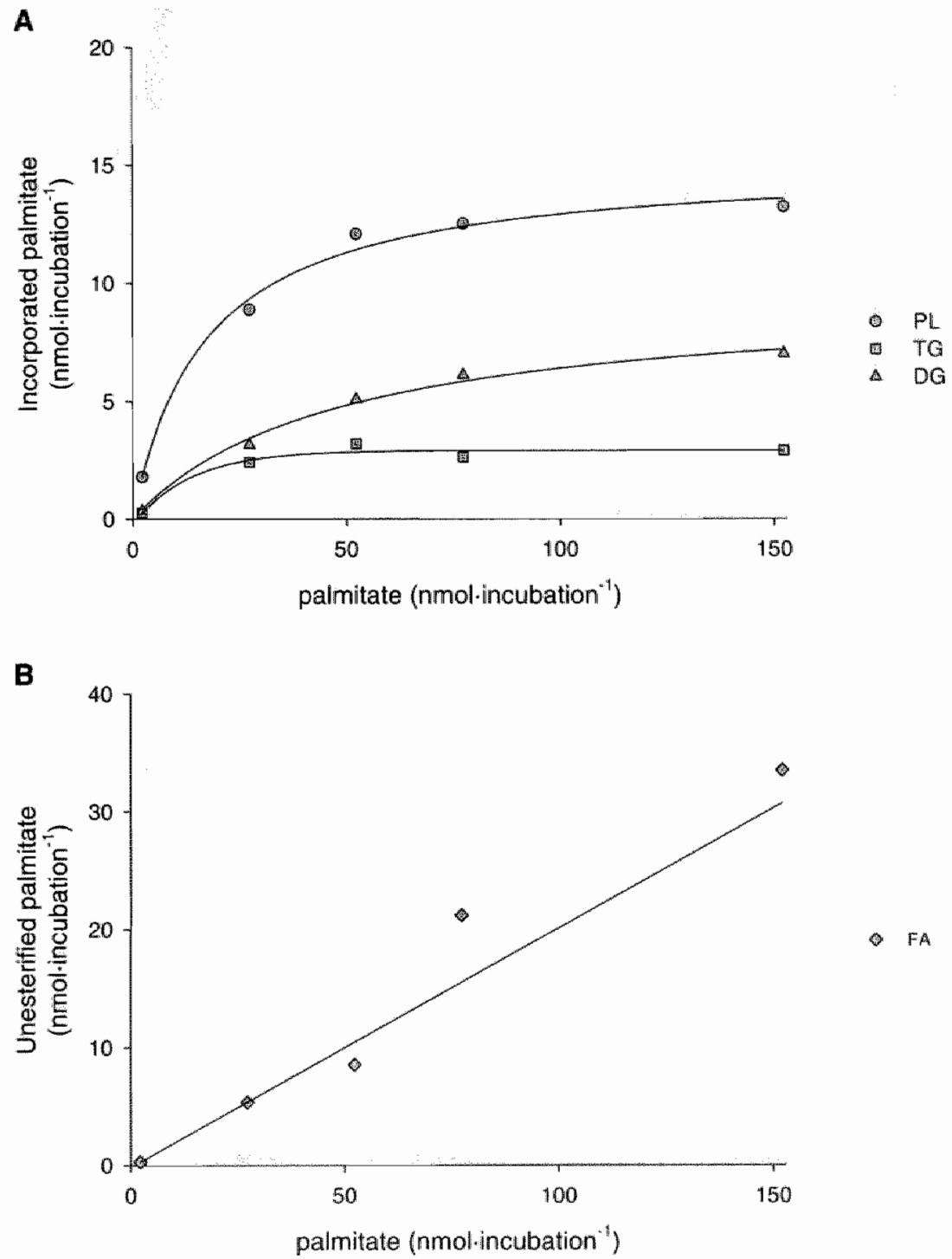

$\mathrm{H} 9 \mathrm{C2}$ cells were incubated with $100 \mu \mathrm{Ci}{ }^{3} \mathrm{H}$-palmitate in the presence of increasing amounts of non-labelled palmitate, varying from o nmol to $150 \mathrm{nmol}$ non-radiolabelled palmitate for 2 hours. Panel-A depicts the amount of esterified palmitate in the phosphollipid (PL), diacylglycerol (DG) and triacylglycerol (TG) pools; Panel-B shows the amount of palmitate in the unesterified fatty acid (FA) pooll. Data are mean $\pm \operatorname{SD}(n=4)$ 
Figure 4.7 Total fatty acid and palmitate content versus ${ }^{3} \mathrm{H}$-fatty acid incorporation in distinct lipid classes
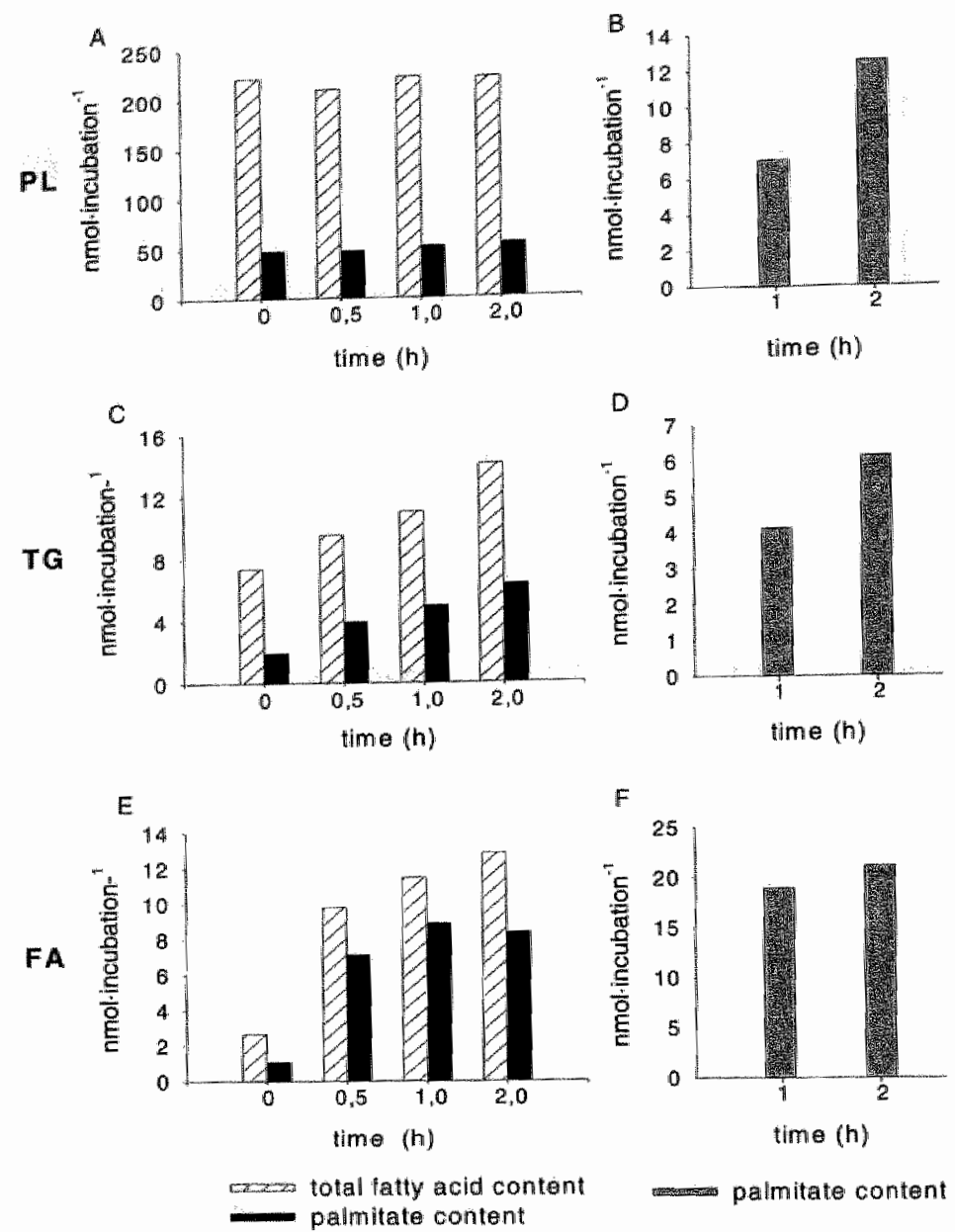

Panels-A, $C$ and $\mathbf{E}$ show the total amount of fatty acyl moieties (striped bars) and that of palmitate (black bars) present in a particular lipid class per incubation. $\mathrm{HgC2}$ cells were incubated in the presence of $77.3 \mathrm{nmol}$ non-labelled palmitate for $0,0.5,1$ and 2 hours (no radioactivity added). For the phospholipids ( $\mathrm{PL}$ ), triacylglycerols (TG) and non-esterified fatty acids (FA) the fatty acyl composition was determined by capillary gas chromatography. Panel-B, D and $\mathbf{F}$ represent the amount of palmitate (grey bars) that became incorporated in a particular lipid class per incubation during 1 and 2 hours. The amount of palmitate incorporated was determined after incubation of $\mathrm{HgC2}$ cells with $100 \mu \mathrm{Ci}{ }^{3} \mathrm{H}$-paimitate (2.3 nmol) in the presence of $75 \mathrm{nmol}$ non-labelled palmitate, taking into account the final specific activity of the palmitate present in the incubation mixture. Data represent the mean of two independent experiments. 
Autoradiography of ${ }^{3} \mathrm{H}$-palmitate labelled proteins after incubation with increasing amounts of exogenous palmitate

Figure 4.8 illustrates that the amount of radioactivity covalently attached to proteins decreased with increasing amounts of non-labelled palmitate. Although this is most prominently seen between 2.3 and $27.3 \mathrm{nmol}$ palmitate, higher amounts of non-labelled palmitate further diminished the number of bands that remained visible.

Table 4.3 shows the change in density of the most prominent bands. The intensity of most protein bands became substantially weaker with increasing palmitate concentrations. The $22 \mathrm{kDa}$ protein band was the most striking exception. The band of this protein showed only a relatively minor decline from 0.60 to 0.45 arbitrary units (a.u.) when the exogenous palmitate concentration was increased from 2.3 to $152.3 \mathrm{nmol}$.

Figure 4.8 Autoradiogram of $\mathrm{Hgc2}$ cells incubated with ${ }^{3} \mathrm{H}$-palmitate in the presence of increasing amounts of non-labelled palmitate, varying from o nmol to $150 \mathrm{nmol}$

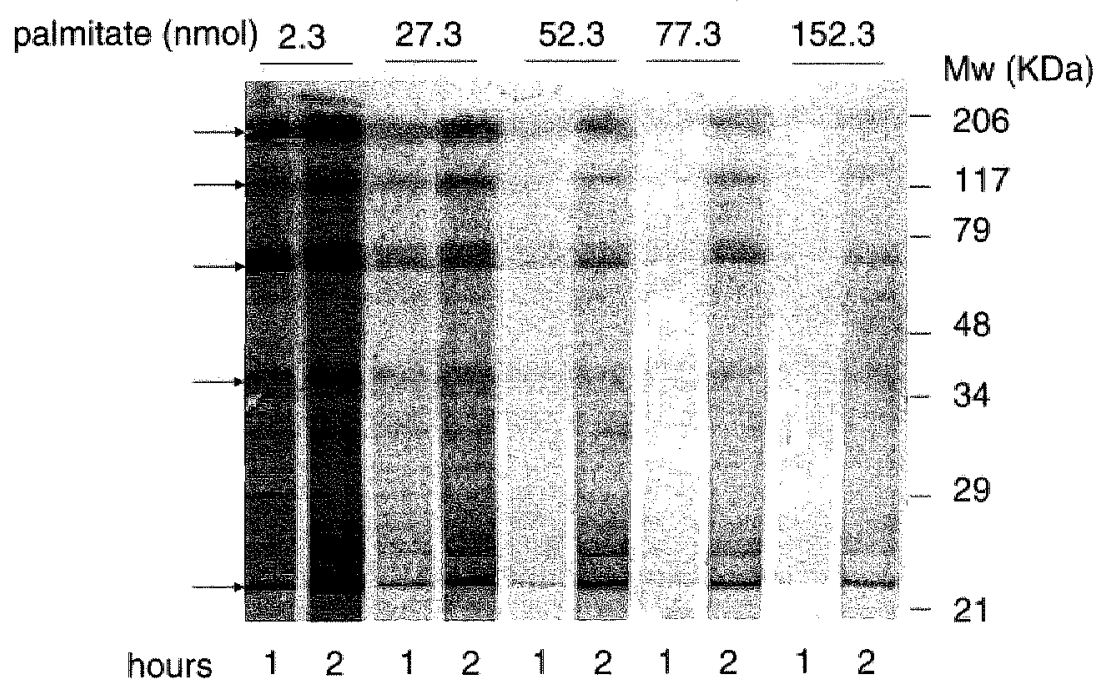

Shown is an autoradiogram obtained after separation of $\mathrm{H} 9 \mathrm{C2}$ proteins using a 4-15\% gradient gel , blotted onto nitro-cellulose, and subjected to 3 weeks exposure to a film. Arrows indicate distinct bands, the quantification of which are summarised in table $\mathbf{4 . 2}$. 
The effect of cerulenin or tunicamycin on inhibition of protein palmitoylation and ${ }^{3} \mathrm{H}$-fatty acid incorporation into cellular lipids

Figure 4.9 shows that both cerulenin and tunicamycin were capable of inhibiting protein acylation in the $\mathrm{H} 9 \mathrm{C} 2$ cell line. Increasing the concentration of cerulenin from 0.1 to $0.3 \mathrm{mM}$ led to an inhibition of $32 \%$ and $54 \%$, respectively, after 1 hour, while increasing the tunicamycin concentration from $10 \mu \mathrm{g} \cdot \mathrm{ml}^{-1}$ to $20 \mu \mathrm{g} \cdot \mathrm{ml}^{-1}$ inhibited protein acylation by $16 \%$ and $29 \%$, respectively, after 1 hour.

Figure 4.9 Inhibition of protein palmitoylation by cerulenin and tunicamycin
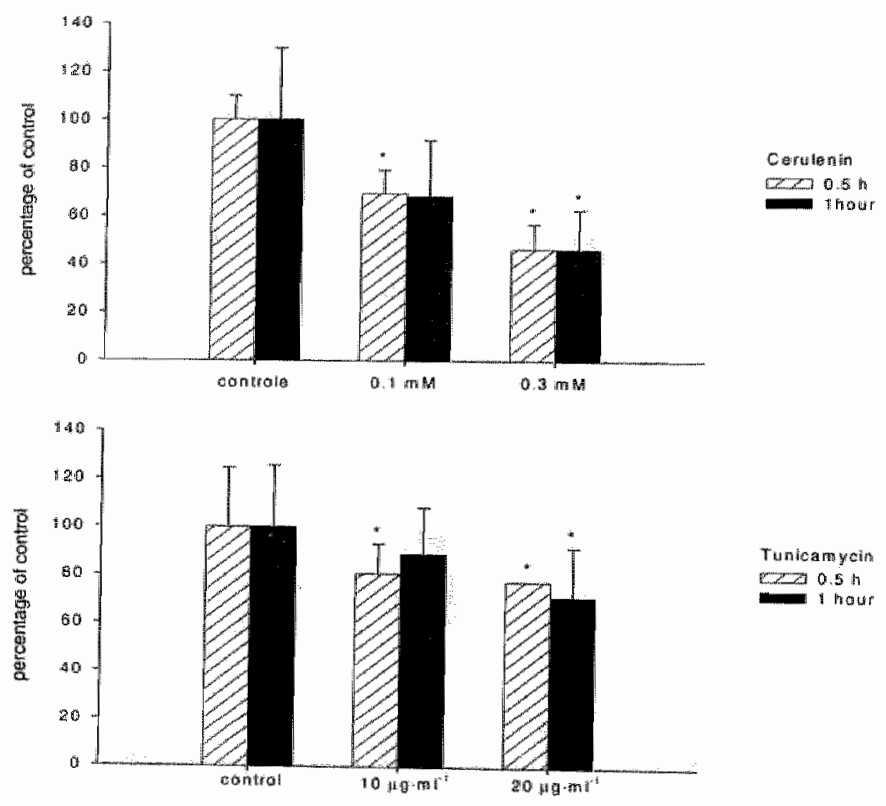

Panel-A H9c2 cells were pre-incubated for 90 minutes with either 0.1 or $0.3 \mathrm{mM}$ cerulenin followed by incubation with $100 \mu \mathrm{Ci}{ }^{3} \mathrm{H}$-palmitate for 30 and 60 minutes. Panel-B. $\mathrm{HgC2}$ cells were incubated with $100 \mu \mathrm{Ci}{ }^{3} \mathrm{H}$-palmitate in the presence of either 10 or $20 \mu \mathrm{g} \cdot \mathrm{ml}^{-1}$ tunicamycin for 30 and 60 minutes. The values shown represent the mean \pm SD and are expressed as percentage of the respective control incubations. $(n=4)$; ${ }^{*}<<0.05$ versus control.

The effect of cerulenin and tunicamycin on ${ }^{3} \mathrm{H}$-fatty acid on incorporation in cellular lipids was determined by measuring the radioactive label present in each lipid class. Incubations with increasing concentrations tunicamycin did not have any effect on the degree of incorporation (figure 4.10). 
Figure 4.10 Effect of cerulenin and tunicarmycin on incorporation of 3 H-palmitate in endogenous lipid pools
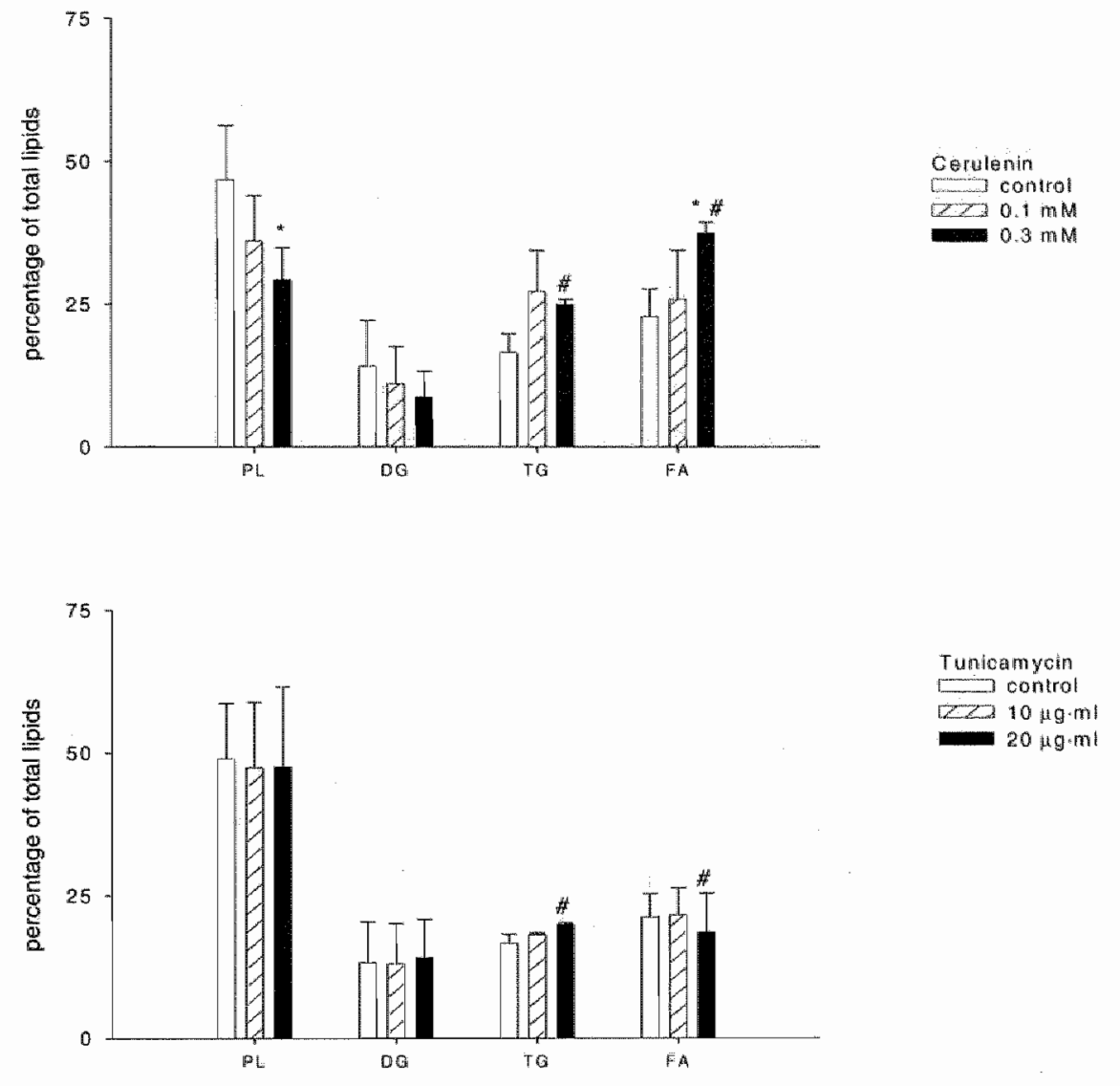

Panel-A, H9c2 cells were pre-incubated for 90 minutes with either 0.1 or $0.3 \mathrm{mM}$ cerullenin followed by incubation with $100 \mu \mathrm{Ci}{ }^{3} \mathrm{H}$-palmitate for 60 minutes. Panel-B, $\mathrm{H} 9 \mathrm{C2}$ cells were incubated with $100 \mu \mathrm{Ci}^{3} \mathrm{H}$-palmitate in the presence of either 10 or $20 \mu \mathrm{g} \cdot \mathrm{ml}^{-1}$ tunicamycin for 60 minutes. PL-phospolipids, DG-diacylglycerols, TG-triacylglycerols, FA-unesterified fatty acids; * $p<0.05$ versus control; $p<0.05,0.3 \mathrm{mM}$ cerulenin versus $20 \mu \mathrm{g} \cdot \mathrm{ml}^{-1}$ tunicamycin

This is in contrast with incubations in the presence of cerulenin. With increasing cerulenin concentrations, a decreasing percentage of ${ }^{3} \mathrm{H}$-palmitate was incorporated into the $\mathrm{PL}$ pool, while the percentage of this fatty acid remaining in the FA pool increased. There was no difference in the percentage of incorporation into the DG and TG pool with increasing cerulenin concentrations. 


\section{Discussion}

\section{The choice of the H9c2 cell line}

The main aim of this study was to investigate some basic properties of protein acylation in cardiac muscle. The $\mathrm{H} 9 \mathrm{c2}$ cell line was chosen as experimental model, since this cell line is derived from embryonic rat heart tissue and thus exhibits several characteristics of cardiomyocytes, such as the expression of the L-type calcium channel ${ }^{14,27}$, and the tissue specific splicing protein $5 \mathrm{mN} 13$. Besides properties of the cardiac muscle, this cell line also possesses properties that are present in skeletal muscle ${ }^{12}$. An additional advantage of this cell line is that the amount of cells that can be obtained is virtually unlimited, in contrast with freshly isolated cardiomyocytes.

\section{Experimental conditions}

For this study, we chose to incubate the cells with $2.3 \mathrm{nmol}{ }^{3} \mathrm{H}$-labelled palmitate, corresponding with $100 \mu \mathrm{Ci}$. This amount was sufficient to enable us to reliably measure incorporation of radioactivity into the protein fraction.

Although myristate is not as abundantly present in cells as is palmitate, we chose to incubate the cells with an amount of myristate comparable with that of palmitate, namely $2.5 \mathrm{nmol}$ myristate, corresponding with $125 \mu \mathrm{Ci}$.

From a pilot study it was known that 2 hours of incubation was an adequate time point to measure protein acylation, while there was still a measurable amount of radioactively labelled unesterified fatty acids left (unpublished result). Therefore, we routinely incubated $\mathrm{H} 9 \mathrm{c} 2$ cells for 2 hours or less.

In the experiment with increasing amounts of exogenous palmitate, we chose for additional amounts of non-labelled palmitate ranging from 0 to $150 \mathrm{nmol}$, to explore whether acylation of proteins shows saturation characteristics. 


\section{Protein acylation and ${ }^{3} \mathrm{H}$-fatty acid incorporation in cellular lipids as function of time.}

\section{Protein acylation}

After the tritiated fatty acids entered the cell only a small percentage of the fatty acids, namely $0.3 \%$ or less became covalently attached to proteins. The bulk of ${ }^{3} \mathrm{H}$-fatty acids was found to be incorporated in the phospholipids ( $\mathrm{PL}$ ), diacylglycerols (DG), and triacylglycerols (TG), or stayed unmetabolised as unesterified fatty acids (FA).

Several lines of evidence proved the covalent binding of ${ }^{3} \mathrm{H}$-labelled fatty acids to proteins. First, the tritiated fatty acid was recovered with the protein fraction after extensive delipidation. Furthermore, the tritiated fatty acids could not be separated from the proteins by SDS-PAGE.

Protein synthesis influences the rate of palmitoylation as well as myristoylation, although the impact of protein synthesis of the latter is of more importance due to the co-translation aspects of this process. The finding that comparable amounts of myristate and palmitate became covalently attached to proteins after incubation with these tritiated fatty acids, strongly suggests a relatively high rate of protein synthesis in these cells, even though the cells are two days after reaching confluency.

\section{Autoradiography}

The differences observed in the degree of covalent attachment of tritiated fatty acids to distinct proteins bands are remarkable. The relative quantity fluctuates not only in time, but also between the different proteins. When reviewing the development of the relative quantity in time, it is most likely that different proteins have different steady state situations. Besides differences in the turnover rate of the covalently attached fatty acid, preferential incorporation into certain proteins and/or the availability of multiple acylation sites could also explain the observed results.

\section{Incorporation into cellular lipids}

After fatty acids are taken up, they are converted to fatty acyl-CoA's. These on their turn can be used for protein acylation or for incorporation of the fatty acyl moiety into diacylglycerols, triacylglycerols or phospholipids via the formation of phosphatidate (diacylglycerol 3-phosphate) ${ }^{28}$. After incubation 


\section{2 | Chapter 4}

of $\mathrm{Hgc2}$ cells with ${ }^{3} \mathrm{H}$-labelled fatty acids radioactive label will therefore be recovered in the $\mathrm{PL}, \mathrm{DG}$, or $\mathrm{TG}$ pool. When no conversion of the ${ }^{3} \mathrm{H}$-fatty acid to fatty acyl-CoA takes place, and thus the fatty acid remains unesterified, it can be recovered in the FA pool.

incubation of $\mathrm{H} 9 \mathrm{c2}$ cells with ${ }^{3} \mathrm{H}$-palmitate as well as with ${ }^{3} \mathrm{H}$-myristate led to incorporation into the PL-pool from $40 \%$ to $60 \%$ between 30 minutes to 2 hours. It is rather surprising that the incorporation of myristate in the $\mathrm{PL}$ pool is on the same order of magnitude as palmitate. This is most striking, especially when taking into account the relative fatty acyl composition of the PL pool in the rat heart ${ }^{11}$, which shows that myristate is a relatively uncommon fatty acid in the PL pool. The unexpected high percentage of labelled myristate in the PL pool could be due to the surplus of myristate in our experimental set-up as compared to normal in vivo circumstances in the rat heart. This would indicate that the enzymes involved in phospholipid syrithesis make no distinction between palmitate and myristate, and thus that the relative fatty acid composition of the PL pool strongly depends on the species of fatty acids that are available.

\section{The effect of the concentration of exogenous palmitate}

\section{Palmitoylation and autoradiography}

Increasing exogenous palmitate concentrations does not only lead to an increased amount of palmitate covalently attached to proteins, but more importantly, it shows that protein palmitoylation is also a saturatable process. At $0.35 \mathrm{nmol}$ palmitate per $\mathrm{mg}$ protein, the protein palmitoylation seems to be saturated. This could mean that the acylation of the majority of proteins that can be modified by covalent attachment of fatty acids have reached a steady state situation.

From figure 4.8 and table 4.3 it can be concluded that there is a remarkable difference in the effect of increasing the amount of exogenous paimitate on the degree of covalent binding of ${ }^{3} \mathrm{H}$-palmitate to proteins. Dilution of labelled palmitate by non-labelled fatty acids resulted, as expected, in an appreciable decline of intensity of the protein bands under investigation. The $22 \mathrm{kDa}$ band, however, showed to be relatively insensitive to the increasing amount of non-labelled palmitate. This indicates that this particular protein has a relatively high capacity for covalent binding of fatty acids such as palmitate. 
Incorporation into cellular lipids

Figure-4.6 shows that the incorporation of palmitate into the various lipid classes saturates at higher exogenous palmitate levels. In contrast, the content of unesterified palmitate linearly increased when the concentration of palmitate in the incubation mixture was enhanced. This indicates that the capacity of the H9c2 cells to incorporate exogenous fatty acids into their esterified lipid pools is exceeded when the supply of extracellular fatty acids is increased. The increase in FA and DG content at high extracellular palmitate levels in the $\mathrm{H} 9 \mathrm{C} 2$ cells could have a major impact on intracellular signal transduction pathways leading, for example, to apoptosis ${ }^{29-31}$, activation of protein kinase $C^{32,33}$ as well as numerous other signal transduction cascades $2,34-38$.

The increase of the amount of palmitate in the TG pool during 2 hours of incubation with a concomitant increase in the total amount of fatty acids in this particular pool (figure 4.7, panel C) can be explained by the increase in incorporation of exogenous palmitate (figure 4.7, panel D). In contrast, the fact that the palmitate content in the phospholipid pool did not measurable change during the two hours of incubation (figure 4.7, panel A) while the amount of exogenous palmitate incorporated increased substantially during the incubation period (figure 4.7 panel B), suggests that in this particular esterified lipid pool the palmitoyl moieties are subjected to a turnover process without a net increase in the amount of cellular phospholipids.

\section{Inhibition of protein acylation by cerulenin or tunicamycin}

\section{Palmitoylation}

In order to study whether protein palmitoylation could be inhibited in the $\mathrm{H} 9 \mathrm{C} 2$ cell line we used cerulenin and tunicamycin, previously described as inhibitors of protein palmitoylation ${ }^{19,20,39} \mathrm{in}$, for instance, adipocytes and PC12 cells. The present findings indicate that also in the cardiac-like $\mathrm{H} 9 \mathrm{C2}$ cells these compounds are able to inhibit palmitoylation of proteins.

\section{Incorporation into cellular lipids}

The effect on ${ }^{3} \mathrm{H}$-palmitate incorporation in the $\mathrm{PL}, \mathrm{DG}$, and TG pool differed between cerulenin and tunicamycin. There was no difference in pattern and percentage of incorporation between control incubations and incubations 


\section{4 | Chapter 4}

with increasing tunicamycin concentrations. This was in contrast with incubations with increasing concentration of cerulenin which led to a decrease of incorporation into the PL and DG pool, and increase of incorporation into the TG pool, while more fatty acids remained unesterified. This difference indicates that the underlying, inhibitory mechanism differs between cerulenin and tunicamycin. Cerulenin may inhibit the lipidesterification pathway beyond phosphatidate (diacylglycerol 3-phosphate), a common intermediate in the synthesis of phospholipids and triacylglycerols. This notion is based on the fact that incorporation of label into phospholipids was decreased, but not into triacylglycerols.

In summary, the present study showed that the $\mathrm{Hgc2}$ model system is suited for studying basic properties of protein acylation in cardiac-like muscle cells. We showed that the amount of fatty acid covalently attached to proteins increased with time. The majority of the fatty acids applied were incorporated into the various lipid classes with phospholipids as the most prominent pool. Furthermore, protein acylation can be saturated by increasing the amount of fatty acids applied to the cells. This also leads to redistribution of the fatty acid over the various lipid pools. Incubations with two known protein inhibitors, cerulenin and tunicamycin, in the $\mathrm{H} 9 \mathrm{c} 2$ cell line also led to a significant decrease in covalent attachment of fatty acids to proteins. 


\section{References}

1. Van der Vusse, GJ, Glatz, JF, Stam, HC and Reneman, RS. Fatty acid homeostasils in the normoxic and ischemic heart. Physiol Rev 72: 881-940, 1992.

2. Graber, $R$, Sumida, $C$ and Nunez, EA. Fatty acids and cell signal transduction. $/$ Lipid Mediat Cell Signal 9: 91-116, 1994.

3. Milligan, G, Parenti, $M$ and Magee, Al. The dynamic role of palmitoylation in signal transduction. Trends Biochem Sci 20: 181-187, 1995.

4. Ordway, RW, Singer, JJ and Walsh, JV, Jr. Direct regulation of ion channels by fatty acids. Trends Neurosci 14: 96-100, 1991.

5. Van Bilsen, $\mathbf{M}$, de Vries, JE and Van der Vusse, GJ. Lang-term effects of fatty acids on cell viability and gene expression of neonatal cardiac myocytes. Prostaglandins Leukot Essent Fatty Acids 57: 39-45, 1997.

6. Dunphy, JT and Linder, ME. Signalling functions of protein palmitoylation. Biochim Biophys Acta 1436: 245-261, 1998.

7. McCabe, JB and Berthiaume, $L_{G}$. Functional roles for fatty acylated amino-terminal domains in subcellular localization. Mol Biol Cell 10: 3771-3786, 1999.

8. Resh, MD. Fatty acylation of proteins: new insights into membrane targeting of myristoylated and palmitoyllated proteins. Biochim Biophys Acta 1451: 1-16, 1999.

9. Stoffel, RH, Inglese, J, Macrae, AD, Lefkowitz, RJ and Premont, RT. Palmiltoylation increases the kinase activity of the $G$ protein-coupled receptor kinase, GRK6. Biochemistry 37: 16053-16059, 1998.

10. Yang, S, Zhang, L and Huang, Y. Membrane association and conformational change of palmitoylated G(O)alpha. FEBS Lett 498: 76-81., 2001.

11. Van der Vusse, GJ and Roemen, TH. Protein acylation in normoxic and ischemic/reperfused cardiac tissue. Prostaglandins Leukot Essent Fatty Acids 60: 299-305, 1999.

12. Kimes, BW and Brandt, BL. Properties of a clonal muscle cell line from rat heart. Exp Cell Res $98: 367-381,1976$.

13. Gerrelli, D, Huntriss, JD and Latchman, DS. Antagonistic effects of retinoic acid and thyroid hormone on the expression af the tissue-specific splicing protein $5 \mathrm{mN}$ in a clonal cell line derived from rat heart. I Mol Cell Cardiol 26: 713-719, 1994.

14. Mejia-Alvarez, R, Tomaselli, GF and Marban, E. Simultaneous expression of cardiac and skeletal muscle isoforms of the L-type Ca2+ channel in a rat heart muscle cell line. $J$ Physiol 478 (Pt 2): 315-329, 1994.

15. Brostrom, MA, Reilly, BA, Wilson, FJ and Brostrom, CO. Vasopressin-induced hypertrophy in $\mathrm{HgC2}$ heart-derived myocytes. Int I Biochem Cell Biol 32: 993-1006, 2000.

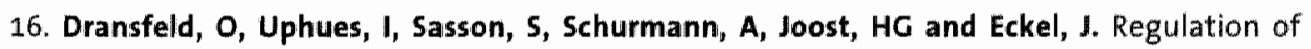
subcellular distribution of GLUT4 in cardiomyocytes: Rab4A reduces basal glucose transport and augments insulin responsivemess. Exp Clin Endocrinol Diabetes 108: 26-36, 2000 . 


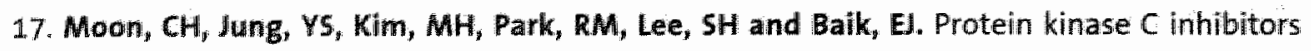
attenuate protective effect of high glucose against hypoxic injury in H9c2 cardiac cells. Jpn J Physiol 50: 645-649, 2000.

18. Van Der Lee, KA, Willemsen, PH, Van Der Vusse, GJ and Van Bilsen, M. Effects of fatty acids on uncoupling protein-2 expression in the rat heart. Faseb 1 14:495-502, 2000.

19. Patterson, $\$$ I and 5 kene, JH. Inhibition of dynamic protein palmitoylation in intact cells with tunicamycin. Methods Enzymol 250: 284-300, 1995.

20. Schlesinger, $M J$ and Malfer, $C$. Cerulenin blocks fatty acid acylation of glycoproteins and inhibits vesicular stomatitis and Sindbis virus particle formation. J Biol Chem 257: 9887$9890,1982$.

21. Wessel, D and Flugge, UI. A method for the quantitative recovery of protein in dilute solution in the presence of detergents and lipids. Anal Biochem 138: 141-143, 1984.

22. Muszbek, L and Laposata, $M$. Covalent modification of platelet proteins by palmitate. Blood 74: 1339-1347, 1989.

23. Roemen, TH, Keizer, $H$ and Van der Vusse, GJ. Quantitative assessment of gammalinolenic acid in human blood and plasma with capillary gas chromatography. $J$ Chromatogr 528: 447-45:2, 1990.

24. Van der Vusse, GJ, Roemen, TH, Prinzen, FW, Coumans, WA and Reneman, R5. Uptake and tissue content of fatty acids in dog myocardium under normoxic and ischemic conditions. Circ Res 50: 538-546, 1982.

25. Morrison, WR and smith, LM. Preparation of fatty acid methylesters and dimethylacetals from lipids with boron fluoride-methanol. J. Lipid Res. 5: 600-608, 1964.

26. Laemmll, UK. Cleavage of structural proteins during the assembly of the head of bacteriophage T4. Nature 227:680-685, 1970.

27. Hescheler, J, Meyer, R, Plant, S, Krautwurst, D, Rosenthal, W and Schultz, G. Morphological, biochemical, and electrophysiological characterization of a clonal cell (H9c2) line from rat heart. Circ Res 69: 1476-1486, 1991.

28. Jackowski, S, Wang, J and Baburina, I. Activity of the phosphatidylcholine biosynthetic pathway modulates the distribution of fatty acids into glycerolipids in proliferating cells. Biochim Biophys Acto 1483: 301-315, 2000.

29. de Vries, JE, Vork, MM, Roemen, TH, de Jong, VF, Cleutjens, JP, Van der Vusse, GJ and Van Bilsen, M. Saturated but not mono-unsaturated fatty acids induce apoptotic cell death in neonatal rat ventricular myocytes. J Lipid Res 38: 1384-1394, 1997.

30. Listenberger, LL, Ory, DS and Schaffer, JE. Palmitate-induced apoptosis can occur through a ceramide-independent pathway. J Biol Chem 276: 14890-14895, 2001.

31. 5paragna, GC and Hickson-Bick, DL. Cardiac fatty acid metabolism and the induction of apoptosis. Am I Med Sci 318: 15-21, 1999.

32. Bell, RM, Hannun, YA and Loomis, CR. Mechanism of regulation of protein kinase C by lipid second messengers. Symp Fundam Cancer Res 39: 145-156, 1986. 
33. Huang; KP. The mechanism of protein kinase $C$ activation. Trends Neurosci 12: 425-432, 1989.

34. Aragones, J, Jones, DR, Martin, S, San Juan, MA, Alfranca, A, Vidal, F, Vara, A, Merida, I and Landazuri, MO. Evidence for the involvement of diacylglycerol kinase in the activation of hypoxia-inducible transcription factor 1 by low oxygen tension. $J$ Biol Chem 276: 10548. $10555,2001$.

35. Bishop, WR and Bell, RM. Functions of diacy/glycerol in glycerolipid metabolism, signal trainsduction and cellular transformation. Oncogene Res 2: 205-218, 1988.

36. Ohanian, J and Ohanian, V. Lipid second messenger regulation: the role of diacylglycerol kimases and their relevance to hypertension. $J$ Hum Hypertens 15: 93-98, 2001.

37. Rodriguez de Turco, EB, Tang, W, Topham, MK, Sakane, F, Marcheselli, VL, Chen, $C_{\text {, }}$ Taketomi, A, Prescott, SM and Bazan, NG. Diacylglycerol kinase epsilon regulates seizure susceptibility and long-term potentiation through arachidonoyl-inositol lipid silgnaling. Proc Natl Acad SciU SA 98: 4740-4745, 2001.

38. Topham, MK and Prescott, SM. Diacylglycerol kinase zeta regulates Ras activation by a novel mechanism. J Cell Biol 152: 1135-1143, 2001.

39. Jachen, AL, Hays, J and Mick, G. Inhibitory effects of cerulenin on protein palmitoylation and insulin internalization in rat adipocytes. Biochim Biophys Acta 1259:65-72, 1995. 



\section{Chapter 5}

Acylated proteins in control and streptozotocin-induced diabetic rat myocardium 


\section{SUMMARY}

In addition to a prominent role in tissue energy conversion, long-chain fatty acids (FA) are involved in signal transduction and modulation of cellular protein localisation and function. The latter is accomplished by acylation of a variety of cellular proteins. In the present study the total amount of fatty acyl moieties covalently bound to cardiac proteins and the effect of streptozotocin-induced diabetes on the degree and relative fatty acyl composition of cardiac proteins have been investigated in isolated rat hearts. In the control hearts circa $0.43 \%$ of the cellular fatty acyl pool is covalently bound to proteins. Approximately $93 \%$ of these fatty acyl chains are thioesterified, whereas a relatively minor part is attached to cardiac proteins through amide linkage. Thio-esterified fatty acyl chains are derived from palmitic, stearic, oleic, linoleic, arachidonic and docosahexaenoic acid. In contrast, amide linked protein acylation shows a strong preference for myristic acyl chains.

Streptozotocin-induced diabetes did significantly enhance the myocardial content of FA, but did not affect the degree of myristoylation of cardiac proteins. In contrast, the total content of thio-esterified fatty acyl chains significantly increased by $22 \%$.

In incubations with isolated myocytes derived from control and diabetic rat hearts, the amount of labelled ${ }^{3} \mathrm{H}$-palmitate $(2.3 \mathrm{nmol}$ per incubation) incorporated in the cellular protein fraction increased significantly from $0.02 \pm 0.01$ (control) to $0.05 \pm 0.01 \mathrm{nmol}$ palmitoyl moieties per mg protein (diabetic). Ketone bodies did not influence the rate of palmitoylation. However, when the palmitate concentration was raised from $2.3 \mathrm{nmol}$ to $152.3 \mathrm{nmol}$ palmitate per incubation ketone bodies significantly increased the rate of protein palmitoylation in diabetic and not in control cells.

\section{INTRODUCTION}

In the myocardium adequate oxidative energy conversion is an absolute requirement for proper mechanical function. Blood-borne long-chain fatty acids (FA) are an important source of oxidisable substrates, since under control conditions approximately $70 \%$ of the cardiac energy need is fulfilled by oxidation of lipids ${ }^{1}$. Previous studies ${ }^{2,3}$ have shown that the tissue content of FA in the non-esterified form is very low, whereas the bulk of cellular fatty acyl moieties is present in phospholipids, being crucial building blocks of biological membranes. In addition, appreciable proportions of the cellular fatty acyl chains are incorporated in the neutral lipid pool (triacylglycerols) ${ }^{1}$. 
During the past decade evidence is accumulating that FA, apart from playing a prominent role in cellular energy conversion and being important constituents of membrane phospholipids, act as intracellular signal transducers 4, 5. Moreover, FA are able, among others, to modulate the biological activity and intracellular localization of a number of proteins ${ }^{6_{n}}$. The latter was found to be accomplished by co-translational or posttranslational modification of these proteins by covalent attachment of fatty acyl chains to specific amino acid residues in the protein molecule. Acylation of proteins either occurs via linkage of the fatty acyl chain to the $\alpha$-amino group of an N-terminal glycine residue through an amide bond or via a linkage to a cysteine residue through a thio-ester bond ${ }^{8}$.

Despite the importance of FA for cardiac functioning, there is a paucity of information on the degree of protein acylation in cardiac structures under control and diabetic conditions, as the latter is known to have severe implications for cardiac fatty acid handling ${ }^{1}$.

This lack of information prompted us to address the following aims:

- assessment of the content of acylated proteins in control rat cardiac tissue (both thio-esterified and amide linked)

- assessment of the effect of diabetes, streptozotocin-induced, on the rat cardiac content of acylated proteins

- elucidation of the relative fatty acid fatty acyl composition of acyl moieties covalently bound to cardiac proteins, in control and diabetic rat hearts.

- clarification of the relationship between the degree of protein acylation and the cardiac tissue content of non-esterified and glycerol-esterified FA.

- Assessment of the rate of protein palmitoylation and the effect of diabetes and ketone bodies thereon in isolated adult cardiomyocytes. 


\section{METHODS}

\section{Induction of diabetes by streptozotocin}

Male Lewis rats were fed ad libitum, had free access to water, and were kept under a light-dark cycle of 12 hours ${ }^{10}$. The Institutional Animal Care and Use Committee, Maastricht University, approved the experiments.

Animals (200-250 $\mathrm{g}$ body weight) were anaesthetized with ketamine and xylazine (Eurovet, Bladel, The Netherlands), 37.5 and $7.5 \mathrm{mg} \cdot \mathrm{kg}^{-1}$, respectively, via intraperitoneal injection. Subsequently, the animals $(n=10)$ were treated with $70 \mathrm{mg} \cdot \mathrm{kg}^{-1}$ streptozotocin (STZ) in disodium citrate (100 $\mathrm{mM}, \mathrm{pH} 4.5$ ) via intravenous injection in the tail vein to induce type-1 diabetes, and received a subcutaneous injection of $2.5 \mathrm{ml} 20 \%(\mathrm{w} / \mathrm{v}) \mathrm{glucose}$ on both lateral sides. Controls $(n=12)$ received vehicle only. STZ-treated animals were given daily a $5 \%$ glucose solution to drink. Four weeks after STZ treatment, rats were anaesthetized with a subcutaneous injection of $48 \mathrm{mg}$ sodium pentobarbital (CEVA Sante Animale B.V., Maassluis, The Netherlands). After thoracotomy, hearts were removed from the thorax, rinsed in ice-cold saline solution and ventricles were freeze-clamped with the used liquid $\mathrm{N}_{2}$ chilled aluminium tongues.

\section{Analysis of fatty acyl moieties in cardiac tissue}

Aliquots of deeply frozen tissue (100-200 mg wet weight) were pulverised in an aluminium mortar with a stainless steel pestle, both previously cooled in liquid nitrogen. The tissue powder was transferred to test tubes cooled with liquid nitrogen. The techniques to extract lipids from powdered cardiac tissue and the quantitative analysis of fatty acyl moieties present in the various lipid fractions and acylated protein pool are based on a combination of modified analytical techniques published earlier by Hasselbaink and colleagues ${ }^{11}$ and Muszbek and Laposata ${ }^{12}$. In short, test tubes with pulverised tissue were placed at $-21^{\circ} \mathrm{C}$ and the tissue powder was wetted with $2 \mathrm{ml}$ of ice-cold methanol. The content of the test tubes was allowed to warm up to room temperature and was subsequently weighed. Thereafter, $4 \mathrm{ml}$ of chloroform was added and lipids were extracted. The chloroform/methanol ( $2: 1$, by volume) extraction step was repeated 2 times. Lipids were analysed as described in details according to Hasselbaink and co-workers ${ }^{11}$ and Van der Vusse and Roemen ${ }^{10}$. The remaining tissue residue was used for the assessment of acylated proteins. 
The tissue residue obtained after extraction with chloroform/methanol (2:1, by volume) was further extensively extracted with $6 \mathrm{ml}$ chloroform/methanol $(1: 2$, by volume), $6 \mathrm{ml}$ chloroform/methanol/ $\mathrm{H} 2 \mathrm{O}$ (1:1:0.3, by volume) and finally with $6 \mathrm{ml}$ methanol. The latter extracts were discarded, since it was found that they contained only minute amounts of fatty acyl moieties (data not shown).

The remaining tissue residue was subsequently dried at $37^{\circ} \mathrm{C}$ under a gentle stream of nitrogen. Thereafter, the dried residue was subjected to alkaline hydrolysis to transmethylate fatty acyl moieties attached to tissue proteins via thio-esterification. To this end, $2 \mathrm{ml} 0.2 \mathrm{M} \mathrm{KOH}$ in methanol was added to the dried material and the mixture was incubated in a tightly capped test tube under $\mathrm{N}_{2}$ atmosphere at $37^{\circ} \mathrm{C}$ for 30 minutes. The content of the test tube was subsequently centrifuged at $4500 \mathrm{~g}$, at $20^{\circ} \mathrm{C}$ for 10 minutes. The pellet was used for acid hydrolysis (see below). The supernatant was mixed with $0.25 \mathrm{ml} 2 \mathrm{M} \mathrm{HCl}$ in $\mathrm{H}_{2} \mathrm{O}$ and subsequently extracted with 1 $\mathrm{ml}$ hexane ( 3 times). The combined hexane extracts were subjected to the above mentioned methylation procedure and the amount of methylesters obtained was quantified by capillary gas chromatography ${ }^{11}$.

The pellet obtained after alkaline hydrolysis was washed two times with $2 \mathrm{ml}$ methanol. Thereafter, $2 \mathrm{ml} 3 \mathrm{M} \mathrm{HCl}$ in methanol was added and the mixture was incubated at $110^{\circ} \mathrm{C}$ under nitrogen atmosphere in a tightly capped test tube for $24 \mathrm{~h}$. Thereafter, the incubation mixture was extracted 3 times with $1.5 \mathrm{ml}$ hexane. The combined extracts were dried under $\mathrm{N}_{2}$ at $37^{\circ} \mathrm{C}$, methylated and the amount of methylesters was quantified with the use of capillary gas chromatography.

In a subset of experiments the procedure to extract lipids from cardiac tissue (the various chloroform/methanol steps mentioned above) was repeated once to test whether lipid extraction was complete prior to alkaline and acid hydrolysis of the tissue residue.

\section{Isolation of cardiac myocytes}

For the isolation of cardiomyocytes, the hearts were placed in ice-cold buffer A containing in $\mathrm{mM}: 115 \mathrm{NaCl}, 2.6 \mathrm{KCl}, 1.2 \mathrm{KH}_{2} \mathrm{PO}_{4}, 1.2 \mathrm{MgSO}_{4}, 10 \mathrm{NaHCO}_{3}$, 10 HEPES, 11 glucose, $\mathrm{pH}$ 7.4). The aorta was mounted on a cannula (diameter $2.0 \mathrm{~mm}$ ) and hearts were perfused at $37^{\circ} \mathrm{C}$ for 5 minutes with buffer $A$ at a flow-rate of $7 \mathrm{ml} \cdot \mathrm{min}^{-1}$ retrogradelly according to Langendorff to remove blood from the coronary circulation. Thereafter, recirculating perfusion was started using $40 \mathrm{ml}$ buffer A supplemented with $0.7 \%$ (w/v) BSA, $0.075 \%(\mathrm{w} / \mathrm{v})$ collagenase and $15 \mathrm{mM}$ butanedione monoxime. After 1 
minute, flow rate was increased to $8 \mathrm{ml} \cdot \mathrm{min}^{-1}$ and then increased linearly to $14 \mathrm{ml} \cdot \mathrm{min}^{-1}$ at 15 minutes after the start of the recirculating perfusion. Flow was allowed to continue at this level for 1 minute. At time points 2 and 12 minutes $40 \mu 10.1 \mathrm{mM} \mathrm{CaCl}_{2}$ was added to the perfusion buffer. At the end of the perfusion period, the heart was removed from the cannula, transferred to a Petri dish and carefully opened using forceps. The opened heart was incubated with $10 \mathrm{ml}$ perfusate and $10 \mathrm{ml}$ medium $B$ (medium $A$ supplemented with $0.2 \mathrm{mM} \mathrm{Ca}{ }^{2 *}$ and $2 \% \mathrm{BSA}$ ) for 10 minutes in a shaking waterbath $\left(37^{\circ} \mathrm{C}, 180 \mathrm{rev} . / \mathrm{min}\right)$ ( $\mathrm{HT}$ Infors, model Aquatron, Bottmingen, 5 witzerland). The heart was subsequently transferred to a Petri dish and was further dissected with forceps. After dissection, the suspension was transferred to an Erlenmeyer flask and placed in a shaking waterbath $\left(37^{\circ} \mathrm{C}\right.$, $180 \mathrm{rev} . / \mathrm{min}$ ) for 5 minutes while the $\mathrm{Ca}^{2+}$ concentration was increased with steps of $200 \mu \mathrm{M}$ to $1 \mathrm{mM}$. Next, cell suspension was filtered through a $0.2 \mathrm{~mm}$ nylon mesh and cardiomyocytes were pelleted by centrifugation $(2 \mathrm{~min}, 17 \mathrm{~g}$ ). The cell pellet was resuspended in medium $C$ (medium $A$ supplemented with $1 \mathrm{mM} \mathrm{Ca}{ }^{2+}$ and $2 \%$ BSA) and centrifuged ( $2 \mathrm{~min}, 23 \mathrm{~g}$ ), and this procedure was repeated once. The cell pellet was resuspended in 20 $\mathrm{ml}$ medium $\mathrm{C}$ and transferred to a $50 \mathrm{ml}$ conical tube. Cardiomyocytes were allowed to rest for 1.5 hours under mild rotation. Prior to the start of the metabolic studies, cells were washed and resuspended in medium $C$.

At the end of the metabolic studies, viability of the cardiomyocytes was assessed by determining the percentage of rod-shaped cells. Furthermore, cellular wet weight was obtained by centrifugation in a microcentrifuge and subsequent removal of the supernatant from samples taken at the end of the performed experiments. All solutions used during the experiment were continuously gassed $\left(\mathrm{O}_{2}: \mathrm{CO}_{2}, 95 \%: 5 \%\right)$.

\section{Incubation of isolated cardiomyocytes}

Prior to the start of the experiments, the cardiomyocytes were washed three times with PBS. Subsequently, cells were incubated for $0,0.5,1$ or 2 hours with $100 \mu \mathrm{Ci}{ }^{3} \mathrm{H}$-labelled palmitate $\left(43 \mathrm{Ci} / \mathrm{mmol}\right.$ ) or $125 \mu \mathrm{Ci}{ }^{3} \mathrm{H}$-labelled myristate $(49 \mathrm{Ci} / \mathrm{mmol})$, each dissolved in $10 \mu \mathrm{l}$ ethanol and transferred to 1 $\mathrm{ml}$ DMEM per flask. Cells were incubated for 2 hours with $100 \mu \mathrm{Ci}(2.3 \mathrm{nmol})$ ${ }^{3} \mathrm{H}$-labelled palmitate in the presence of zero or $150 \mathrm{nmol}$ non-radiolabelled palmitate per incubation. These conditions were supplemented with addition of acetoacetate (AcAC, 3mM), 3- $\beta$-hydroxybutyrate $(3 \mathrm{HB}, 3 \mathrm{mM})$ or a combination of both (2 $\mathrm{mM} \mathrm{ACAC}$ and $4 \mathrm{mM} 3 \mathrm{HB}$ ). At the end of the 
incubation, cells were washed three times with ice-cold PBS. Cells were lysed using $1 \mathrm{ml}$ harvesting buffer $(50 \mathrm{mM}$ Tris- $\mathrm{HCl} \mathrm{pH} \mathrm{7.6,150} \mathrm{mM} \mathrm{NaCl}, 5 \mathrm{mM}$ EDTA, $1 \%$ Triton $X-100(w / v)$, and $10 \mu$ protease inhibitor cocktail) for 30 minutes on ice.

\section{Statistical analysis}

Differences between values obtained in control and diabetic cardiac tissue were analysed with student $t$ test for statistical significance. $P<0.05$ was accepted as a statistically significant difference.

\section{RESULTS AND DISCUSSION}

\section{Fatty acyl content of control and diabetic rat heart}

The bulk of fatty acyl moieties in control and diabetic cardiac tissue are present in the membrane phospholipid fraction (table 5.1). An appreciable proportion of fatty acyl chains are also present in the neutral lipid fraction (triacylglycerols) of the heart. The combined data show that circa $99.6 \%$ of all fatty acyl moieties are esterified to a glycerol backbone. In the control heart minor part of the fatty acyl chains is present in the non-esterified form.

The latter observation corroborates earlier findings ${ }^{2,3}$ and underscores the notion that the cardiac cell is capable of maintaining the content of FA as low as possible. From a teleological point of view, it can be argued that a low intracellular FA content is advantageous for the cardiac myocyte because: i) it prevents FA from a deleterious action on cardiac structures when present in elevated concentrations ${ }^{1}$ and ii) it creates a steep gradient for FA delivered from the blood compartment to cardiac muscle cells. This gradient most likely acts as main driving force for the net uptake of circulating FA by the heart in situ ${ }^{1,13}$.

In the diabetic heart, the content of FA was approximately 4.5 fold higher than in control hearts (table 5.1). This observation is in line with previous findings ${ }^{11,14}$ and indicates that fatty acid handling is disturbed in the diabetic myocardium. Moreover, the amount of triacylglycerols (TG) in diabetic hearts was found to be twice the content in control hearts. The cardiac content of phospholipids (PL) did not differ between control and diabetic hearts. 
Table 5.1 Content of farty acyl moleties in various lipid pools and acylated proteins in control and cardiac tissue.

\begin{tabular}{lll|cc} 
& \multicolumn{2}{c}{ Fatty acyl chains $\left(\right.$ mmol $\left.g^{-1} d w\right)$} & \multicolumn{2}{c}{ Percentage of total fatty } \\
\hline & control & diabetic & control & diabetic \\
Fatty acids (non-esterified) & $346 \pm 110$ & $1,559 \pm 329^{*}$ & 0.22 & 0.93 \\
Triacylglycerols & $27,960 \pm 17,400$ & $44,710 \pm 19,320^{*}$ & 18.4 & 26.4 \\
Phospolipids & $122,980 \pm 31,760$ & $122,100 \pm 34,100$ & 80.9 & 72.2 \\
Acylated proteins & & & & \\
-amide linked & $46 \pm 5$ & $44 \pm 5$ & 0.03 & 0.03 \\
-thio-esterified & $614 \pm 59$ & $748 \pm 72^{*}$ & 0.40 & 0.44 \\
\hline
\end{tabular}

*, significantly different from corresponding value in control hearts $(n=12)$, diabetic hearts $(n=10)$.

In table 5.2 the relative fatty acyl composition of the various lipid classes and acylated proteins is shown. In the control heart the most common fatty acyl moieties in the (non-esterified) FA pool are palmitic, stearic, oleic and linoleic acids. In the diabetic heart, the relative composition of fatty acyl chains in the cellular FA pools shows some significant differences. For instance, in the FA pool the relative presence of stearic, oleic and linoleic acid are significantly increased when compared to control. However, arachidonic and docosahexaenoic acid showed a significant decrease.

\section{Content of acylated proteins in control and diabetic rat heart}

Table 5.1 shows that, although measurable amounts of fatty acyl chains were covalently bound to proteins (on the order of 600 to $700 \mathrm{nmol} \cdot \mathrm{g}^{-1} \mathrm{dry}$ weight of tissue), this fatty acyl pool represents only circa $0.43 \%$ of the total amount of fatty acyl chains present in normoxic cardiac tissue. The alkaline and acid treatment of the protein residue showed that the bulk of fatty acyl moieties bound to cardiac proteins are thio-esterified. Only a minor part (circa $7 \%$ ) of the total fatty acyl pool in acylated proteins is covalently connected to proteins via an amide linkage. As expected the vast majority of fatty acyl chains attached via an amide linkage to cardiac proteins were identified as myristic acyl chains. Therefore, data in table 5.1 refer to the amount of myristoyl chains covalently attached to proteins.

In contrast, the thio-acylated proteins contained substantial amounts of palmitic, stearic and arachidonic acyl chains. Oleic, linoleic and docosahexaenoic acyl moieties contributed to a lesser extent (table 5.2). 
Table 5.2 Relative fatty acyl composition of non-esterified FA and thio-esterified proteins in control and diabetic rat cardiac tissue

\begin{tabular}{ccccc}
\cline { 2 - 5 } Fattyacylchain & \multicolumn{2}{c}{ FA } & \multicolumn{2}{c}{ Thio-esterfied } \\
\hline & Control & Diabetic & Controll & Diabetic \\
\hline myristic acid & $2.5 \pm 1.2$ & $1.9 \pm 0.6$ & $0.1 \pm 0.1$ & $0.3 \pm 0.2$ \\
palmitic acid & $22.4 \pm 2.2$ & $23.4 \pm 1.4$ & $23.5 \pm 0.9$ & $23.8 \pm 1.7$ \\
palmitoleic acid & $1.9 \pm 1.4$ & $1.2 \pm 0.3$ & $0.3 \pm 0.3$ & n.d.* \\
stearic acid & $14.5 \pm 1.5$ & $16.2 \pm 1.5^{*}$ & $31.8 \pm 1.6$ & $32.3 \pm 1.6$ \\
oleic acid & $14.8 \pm 2.4$ & $17.4 \pm 2.1^{*}$ & $12.8 \pm 0.5$ & $12.2 \pm 0.9$ \\
linoleic acid & $25.3 \pm 4.1$ & $29.1 \pm 2.9^{*}$ & $9.6 \pm 0.9$ & $10.1 \pm 1.5$ \\
arachidonic acid & $5.1 \pm 1.5$ & $2.0 \pm 0.8^{*}$ & $18.5 \pm 0.9$ & $16.9 \pm 1.0 *$ \\
docosahexaenoic acid & $8.8 \pm 3.3$ & $6.1 \pm 1.8^{*}$ & $2.7 \pm 0.5$ & $3.3 \pm 0.8$ \\
\hline
\end{tabular}

Data (mean \pm S.D.) are expressed as $\%$ of total amount of fatty acyl moieties in the FA pool and thio-esterified protein fraction, respectively. n.d.=not detectable. "indicates a significant difference between control $(n=12)$ and diabetic $(n=10)$ cardiac tissue.

In the diabetic heart, the content of amide linked fatty acyl chains did not differ from that in control hearts (table 5.1). However, the content of thioesterified fatty acyl chains was significantly enhanced in the diabetic myocardium by $22 \%$. The relative fatty acyl composition of thio-esterified proteins showed that only the percentages of palmitoleic and arachidonic acid were altered. When the pattern of the relative fatty acyl composition of the thio-esterified proteins was compared with that of the FA pool, in the diabetic and control heart, it is striking that the composition of the thioesterified proteins is not similar to the relative fatty acyl pattern of this lipid pool and that it does not follow alterations observed in the cardiac FA pool under diabetic conditions.

Because the acyl chains in acylated proteins represent only a relatively small proportion of the total cellular fatty acyl pool, it was tested whether the acylated protein pool was contaminated with traces of other lipid classes. To this end, the extraction procedure applied to obtain FA, triacylglycerols and phospholipids was repeated once prior to alkaline and acid treatment of the tissue residue. This additional extraction procedure did neither result in a measurable decrease in the amount of fatty acyl chains in the acylated protein pool nor did it affect the relative fatty acyl composition of acylated proteins (thio-esterified or amide linked) (data not shown). 
Protein palmitoylation in isolated adult cardiomyocytes derived from control and diabetic rats.

In isolated myocytes derived from control and diabetic rat hearts, the rate of ${ }^{3} \mathrm{H}$-palmitate $(2.3 \mathrm{nmol}$ per incubation) was significantly higher than in control cells (table 5.3). Addition of ketone bodies did not affect the rate of palmitoylation. When control as well as diabetic cardiomyocytes were incubated with $152.3 \mathrm{nmol}$ palmitate $2.3 \mathrm{nmol}{ }^{3} \mathrm{H}$-labelled and $150 \mathrm{nmol}$ non-labelled palmitate) it was found that under high FA conditions the amount of fatty acyl moieties covalently bound to proteins was significantly increased.

The presence of ketone bodies in the incubation medium did not significantly alter the incorporation of ${ }^{3} \mathrm{H}$-palmitate in the protein fraction of control cardiomyocytes at high i.e. $152.3 \mathrm{nmol}$ palmitate. However, in diabetic cardiomyocytes the presence of ketone bodies significantly altered the incorporation of fatty acyl moieties. In all cases (ACAC, $3 \mathrm{HB}$ or the combination) palmitoylation was increased.

\section{Significance of acylated proteins in cardiac tissue}

In spite of the fact that only $0.43 \%$ of all fatty acyl moieties present in the heart is covalently bound to proteins, this particular fatty acyl pool might play a significant role in the biological function of a number of cardiac proteins. Assuming that the heart contains $800 \mathrm{mg}$ protein per gram dry weight of tissue and that the average molecular mass of cardiac proteins is $40 \mathrm{kDa}$, the ratio of number of fatty acyl chains, covalently bound to cardiac proteins, to the total number of cardiac proteins amounts to $3: 100$. Moreover, studies on other tissues and cell types have shown that some proteins, crucial for normal cellular functioning, such as G-protein $\alpha$ subunits, sodium channel $\alpha$ subunits, various membrane receptors and CD36, are present in the acylated form ${ }^{45-18}$. It should be emphasised, however, that the identity and function of acylated proteins in cardiac tissue is unknown, but is subject of future studies. 
Table 5.3 Protein palmitoylation in isolated cardiomyocytes derived from control and diabetic rats incubated with 2.3 or $152 \mathrm{nmol}$ palmitate in the presence of ketone bodies.

\begin{tabular}{|c|c|c|c|c|}
\hline & \multicolumn{4}{|c|}{2.3 nmal palmitate-incubation ${ }^{-4}$} \\
\hline & $(-1)$ & AcAC & $3 \mathrm{HB}$ & combination \\
\hline Control & $0.02 \pm 0.01$ & $0.03 \pm 0.01$ & $0.03 \pm 0.01$ & $0.02 \pm 0.01$ \\
\hline \multirow[t]{3}{*}{ Diabetic } & $0.05 \pm 0.01^{*}$ & $0.05 \pm 0.01$ & $0.04 \pm 0.01$ & $0.04 \pm 0.01$ \\
\hline & \multicolumn{4}{|c|}{$152.3 \mathrm{nmal}$ palmitate-incubation } \\
\hline & $(-1)$ & ACAC & $3 \mathrm{HB}$ & combination \\
\hline Control & $0.07 \pm 0.02 \#$ & $0.05 \pm 0.01$ & $0.07 \pm 0.01$ & $0.09 \pm 0.02 \#$ \\
\hline Diabetic & $0.11 \pm 0.03 \varsigma^{*}$ & $0.22 \pm 0.041^{*}$ & $0.27 \pm 0.079^{*}$ & $0.21 \pm 0.05 s^{*}$ \\
\hline
\end{tabular}

Data are expressed as nmol palmitoyl moiety.mg protein ${ }^{-1}(n=3)$ * indicates significantly different from corresponding incubations of control cardiomyocytes. indicates significantly different from corresponding cardiomyocytes derived from diabetic rats, incubated with 2.3 nmol palmitate; \# indicates significantly different from corresponding control cardiomyocytes incubated with $2.3 \mathrm{nmol}$ palmitate. (-) means in the absence of ketone bodlies; AcAc; acetoacetate $(3 \mathrm{mM}), 3 \mathrm{HB}_{*}: 3$ - $\beta$-hydroxybutyrate $(3 \mathrm{mM})$; combination refers to a mixture of $3 \mathrm{HB}(4 \mathrm{mM})$ and $\mathrm{ACAC}(2 \mathrm{mM})$.

It is of interest to note that the majority of protein-linked fatty acyl moieties are attached to cardiac proteins via a thio-ester bond "whereas a relatively small proportion is covalently bound via an amide linkage. Amide linkage is accomplished co-translationally by linking the myristoyl chain fatty acid moiety to the $\alpha$-aminogroup of an $\mathrm{N}$-terminal glycine residue through the catalytic action of protein $\mathrm{N}$-myristoyl transferase ${ }^{19}$. Others have shown that thio-esterification in cellular proteins occurs post-translationally via a covalent binding of the carboxyl head group of the fatty acid to the sulphur atom of the cysteine residue in the protein molecule ${ }^{15}$. In myocardial tissue, thio-esterified fatty acyl chains are not only derived from palmitic acid but also from other long-chain saturated and unsaturated FA. This finding indicates that in the heart, like in other organs and cell types, thio-esterification shows a relatively relaxed fatty acyl chain specificity ${ }^{16}$.

Novel is the finding that the content of thio-esterified proteins is enhanced in the diabetic heart. This increase may be caused by the increased intracellular availability of FA ${ }^{11}$ and/or their CoA-derivatives ${ }^{20}$. 
The consequences of enhanced protein thio-esterification on myocardial cells are incompletely understood. This issue can only be resolved if the identity and function of the acylated proteins in cardiac structures is known in full detail. At present one may speculate that the increased levels of acylated proteins may contribute to the altered substrate handling in the diabetic heart and ultimately to the decline in function of the affected organ.

It is of interest to note that in contrast to thio-esterified proteins the cardiac content of myristoylated proteins is not altered in the diabetic state. This finding implies that co-translational acylation of proteins is not affected in diabetic conditions. In contrast, post-translational modification, and in particular thio-esterification appears to be sensitive to alterations in the heart evoked by the diabetic state.

The present findings also show that the rate of protein palmitoylation is intrinsically higher in diabetic cardiomyocytes than in control. Moreover, both increased levels of FA and enhanced availability of ketone bodies significantly further stimulate the rate of palmitoyl incorporation in the protein pool of the diabetic cell. Since in the diabetic animal the in vivo heart is exposed to both elevated FA and ketone body levels, these metabolic alterations provide a feasible explanation for the increase in amount of acylated proteins in the intact diabetic heart. 


\section{REFERENCES}

1. Van der Vusse, GJ, Glatz, JF, Stam, HC and Reneman, RS. Fatty acid homeostasis in the normoxic and ischemic heart. Physiol Rev 72: 881-940, 1992.

2. Van der Vusse, GJ, Roemen, TH, Prinzen, FW, Coumans, WA and Reneman, RS. Uptake and tissue content of fatty acids in dog myocardium under normoxic and ischemic conditions. Circ Res 50: 538-546, 1982 .

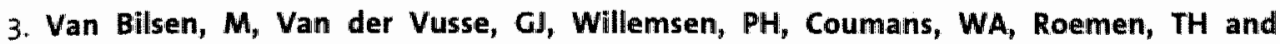
Reneman, RS. Lipid alterations in isolated, working rat hearts during ischemia and reperfusion: its relation to myocardial damage. Circ Res 64: 304-314, 1989.

4. Graber, R, Sumida, $C$ and Nunez, EA. Fatty acids and cell signal transduction. J Lipid Mediat Cell Signal 9: 91-116, 1994.

5. Liscovitch, $M$ and Cantley, LC. Lipid second messengers. Cell 77: 329-334, 1994.

6. Blenis, J and Resh, MD. Subcellular localization specified by protein acylation and phosphorylation. Curr Opin Cell Biol 5: 98.4-989, 1993.

7. James, $G$ and Olson, EN. Fatty acylated proteins as components of intracellular signaling pathways. Biochemistry 29: 2623-2634, 1990.

8. Van Cott, EM, Muszbek, L and Laposata, M. Fatty acid acylation of platelet proteins. Prostaglandins Leukot Essent Fatty Acids 57: 33-37, 1997.

9. Van der Vusse, GJ and Roemen, TH. Protein acylation in normoxic and ischemic/reperfused cardiac tissue. Prostaglandins Leukot Essent Fatty Acids 60: 299-305, 1999.

10. Van der Vusse, GJ and Roemen, TH. Gradient of fatty acids from blood plasma to skeletal muscle in dogs. J Appl Physiol 78: 1839-1843, 1995.

11. Hasselbaink, DM, Roemen, TH and Van der Vusse, GJ. Determination of llong-chain fatty acids, triacylglycerols and phospholipids by capillary gas chromatography in cardiac tissue and blood plasma of normal and diabetic rats. Anal Chim Acta 465: 351-357, 2002.

12. Muszbek, L and Laposata, M. Covalent modification of platelet proteins by palmitate. Blood 74: 1339-1347, 1989.

13. Van der Vusse, GJ, Roemen, TH, Flameng, $\mathbf{w}$ and Reneman, RS. Serum-myocardium gradients of non-esterified fatty acids in dog, rat and man. Biochim Biophys Acta 752: 361-370, 1983.

14. Heyliger, CE, Scarim, AL, Eymer, VP, Skau, KA and Powell, DM. Characteristics of the myocardial PM-FABP: effect of diabetes mellitus. Mol Cell Biochem 176: 281-286, 1997.

15. Olson, EN. Modification of proteins with covallent lipids. Prog Lipid Res 27: 177-197, 1988.

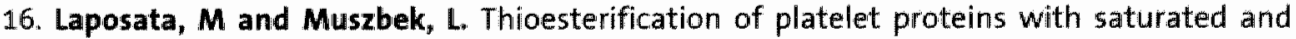
polyunsaturated fatty acids. Lipids 31 Suppl: S217-221, 1996.

17. Hallak, H, Muszbek, L, Laposata, M, Belmonte, E, Brass, LF and Manning, DR. Covalent binding of arachidonate to $G$ protein alpha subunits of human platelets. $J$ Biol Chem 269 : $4713-4716,1994$. 
18. Tao, N, Wagner, 5I and Lublin, DM. CD36 is palmitoylated on both $N$ - and C-terminal Eytoplasmic tails. J Biol Chem 271: 22315-22320, 1996.

19. Towler, DA, Gordon, Il, Adams, SP and Glaser, L. The biology and enzymology of eukaryotic protein acylation. Annu Rev Biochem $57,69-99,1988$.

20. Feuvray, $D$, Idell-Wenger, JA and Neely, $J R$. Effects of ischemia on rat myocardial function and metabolism in diabetes. Circ Res 44: 322-329, 1979. 


\section{Chapter 6}

\section{Ketone bodies disturb fatty acid handling in isolated cardiomyocytes derived from control and diabetic rats}

Part of this chapter is published in: Danny M. Hasselbaink, Theo H.M. Roemen, Jan F. C. Glatz, Joost J. F. P. Luiken and, Ger J. Van der Vusse. Ketone bodies disturb fatty acid handling in isolated cardiac myocytes derived from control and and diabetic rats. Biochemical J. 371 part 3 (2003), 753-760 


\section{Abstract}

According to the current paradigm, the diabetic heart shows an increased oxidation rate of long-chain fatty acids (FA). This notion is mainly based on the outcome of studies on isolated hearts. Taking into account that the plasma concentration of competing substrates, such as ketone bodies, is substantially increased during diabetes, we have explored the effect of these substrates on cardiac fatty acid handling.

Experiments were performed on cardiomyocytes isolated from both control and streptozotocin-induced diabetic rats. Cardiomyocytes were incubated with either normal $(80 \mu \mathrm{M})$ or elevated palmitate concentrations $(160 \mu \mathrm{M})$ in the absence or presence of ketone bodies, either acetoacetate (ACAc), 3- $\beta$-hydroxybutyrate (3HB), or a combination of both.

When diabetic cardiomyocytes were incubated under normal conditions ( $80 \mu \mathrm{M}$ palmitate, no ketone bodies), initial FA uptake rate was found to be identical to that of control cardiomyocytes. However, when diabetic cardiomyocytes were exposed to elevated palmitate concentrations (160 $\mu \mathrm{M}$ palmitate), initial uptake rate was significantly higher than in control cardiomyocytes incubated under normal conditions $(64.0 \pm 13.8$ versus $35.2 \pm 4.8 \mathrm{nmol} \cdot \mathrm{g}$ wet weight- ${ }^{-1} \cdot 3 \mathrm{~min}^{-1}$ ). Neither $3 \mathrm{mM} \mathrm{AcAc}$ nor $3 \mathrm{mM} 3 \mathrm{HB}$ affected the initial uptake rate of palmitate in control and diabetic cardiomyocytes.

Oxidation in palmitate was significantly higher in diabetic cardiomyocytes than in control cells when both were incubated under normal conditions ( $80 \mu \mathrm{M}$ palmitate no ketone bodies), i.e. $92.1 \pm 25.9$ and $58.9 \pm 23.6 \mathrm{nmol} \cdot \mathrm{g}$ wet weight ${ }^{-1} \cdot 30 \mathrm{~min}^{-1}$, respectively. When diabetic cardiomyocytes were also exposed to $3 \mathrm{mM}$ AcAc (in the presence of $160 \mu \mathrm{M}$ palmitate), palmitate oxidation rate dropped to $53.2 \pm 18.5 \mathrm{nmol} \cdot \mathrm{g}$ wet weight ${ }^{-1} \cdot 30 \mathrm{~min}^{-1}$. In contrast, the addition of $3 \mathrm{mM} 3 \mathrm{HB}$ did not affect palmitate oxidation.

Varying the concentration of ACAc in the incubation medium revealed that palmitate oxidation in diabetic and control cardiomyocytes is highly sensitive to ACAC. Half maximum inhibition of palmitate oxidation in booth cell types was reached at 0.3-0.5 mM AcAc.

When diabetic cardiomyocytes were incubated under diabetic conditions (160 $4 \mathrm{M}$ palmitate, $3 \mathrm{mM}$ ACAc) significant amounts of unmetabolized palmitate accumulated inside the cells. This effect was not observed in control cardiomyocytes.

The collected findings indicate that due to the presence of ketone bodies FA oxidation in diabetic cardiomyocytes is not increased, despite the 
elevated supply of extracellular FA. This result may explain the discrepancy observed in FA oxidation rates between isolated hearts and hearts studied in vivo. Moreover, the increase in palmitate uptake and concomitant inhibition of palmitate oxidation in diabetic cardiomyocytes, incubated under diabetic conditions ( $160 \mu \mathrm{M}$ palmitate, $3 \mathrm{mM}$ ACAC), most likely explains the accumulation of FA in the diabetic heart.

\section{Introduction}

Diabetes mellitus (DM) is a clinical syndrome characterized by hyperglycaemia caused by a relative or absolute deficiency of insulin or by resistance to the action of insulin at the cellular level. The diabetic condition leads to a significant elevation of blood glucose and plasma lipids if left untreated ${ }^{1,2}$. Insulin deficiency also results in increased hepatic synthesis of ketone bodies, leading to elevated plasma levels of acetoacetate (ACAC) and 3- $\beta$-hydroxybutyrate $(3 \mathrm{HB})^{3}$, which in turn can evoke serious pathophysiological complications, such as diabetic ketoacidosis.

On the basis of studies on isolated hearts it was concluded that cardiac long-chain fatty acid (FA) oxidation is increased in the diabetic state ${ }^{4 \cdot 6}$. These findings are however at variance with observations on hearts in situ of human diabetic patients ${ }^{7}$. This suggests that FA oxidation by the diabetic heart is governed by factors present in the in situ situation, but absent when isolated rat hearts are studied.

Under normal conditions cardiac energy demand is mainly covered by the oxidation of FA and glucose ${ }^{8}$. Lactate and ketone bodies are also able to serve as oxidizable substrates ${ }^{9}$. It is tempting to state that the discrepancy between isolated hearts and hearts of human diabetic patients with respect to cardiac FA utilization is caused by the availability of alternative substrates, such as ketone bodies.

In the present study we have tested the hypothesis that ketone bodies, $A C A C$ and $3 \mathrm{HB}$, affect both uptake and intracellular handling of FA in diabetic cardiomyocytes. To this end, cardiomyocytes were isolated from diabetic rats, 4 weeks after streptozotocin (STZ) treatment. The cells were exposed to $\mathrm{ACAC}, 3 \mathrm{HB}$, or a combination of both. FA uptake, oxidation, and esterification were studied in the presence of normal (physiological) or increased (diabetic) extracellular FA concentrations. 


\section{Methods}

\section{Treatment of animals}

Male Lewis rats were fed ad libitum, had free access to water, and were kept under a light-dark cycle of 12 hours ${ }^{10}$. The Institutional Animal Care and Use Committee, Maastricht University, approved the experiments.

Animals (200-250 g body weight) were anaesthetized with ketamine and xylazine (Eurovet, Bladel, the Netherlands), 37.5 and $7.5 \mathrm{mg} \cdot \mathrm{kg}^{-1}$, respectively, via intraperitoneal injection. Subsequently, the animals were treated with $70 \mathrm{mg} \cdot \mathrm{kg}^{-1}$ streptozotocin (STZ) in disodium citrate $(100 \mathrm{mM}, \mathrm{pH} 4.5)$ via intravenous injection in the tail vein to induce type 1 diabetes, and received a subcutaneous injection of $2.5 \mathrm{ml} 20 \%$ (w/v) glucose on both lateral sides. Controls received vehicle only. STZ-treated animals were given daily a $5 \%$ glucose solution to drink. Four weeks after STZ treatment, rats were anaesthetized with a subcutaneous injection of $48 \mathrm{mg}$ sodium pentobarbital (CEVA Sante Animale B.V., Maassluis, the Netherlands) and 1000 i.u. of heparin. Thereafter, hearts were surgically removed from the thorax. In a subset of experiments $(n=6)$ the anaesthetized animals did not receive heparin. After thoracotomy, blood was collected from the left ventricle with a citrate rinsed syringe. Blood glucose was measured with Euroflash ${ }^{\mathrm{TM}}$ (Lifescan, Milpitas, CA, USA) and plasma FA by gas chromatography ${ }^{11}$.

\section{Isolation of cardiomyocytes}

Cardiomyocyte isolation procedure was partially adapted from that described by Luiken and colleagues ${ }^{12}$ The surgically removed hearts were placed in ice-cold buffer $A$ (containing in $\mathrm{mM}: 115 \mathrm{NaCl}, 2.6 \mathrm{KCl}, 1.2 \mathrm{KH}_{2} \mathrm{PO}_{4}$, $1.2 \mathrm{MgSO}_{4}, 10 \mathrm{NaHCO}_{3}, 10$ HEPES, 11 glucose, $\mathrm{pH}$ 7.4). The aorta was mounted on a cannula (diameter $2.0 \mathrm{~mm}$ ) and hearts were perfused at $37^{\circ} \mathrm{C}$ for 5 minutes with buffer $A$ at a flow-rate of $7 \mathrm{ml} \cdot \mathrm{min}^{-1}$ retrogradelly as described by Langendorff ${ }^{13}$ to remove blood from the coronary circulation. Thereafter, recirculating perfusion was started using $40 \mathrm{ml}$ of buffer $A$ supplemented with $0.7 \%(\mathrm{w} / \mathrm{v}) \mathrm{BSA}, 0.075 \%(\mathrm{w} / \mathrm{v})$ collagenase and $15 \mathrm{mM}$ butanedione monoxime. After 1 minute, flow rate was increased to $8 \mathrm{ml} \cdot \mathrm{min}^{-1}$ and then increased linearly to $14 \mathrm{ml} \cdot \mathrm{min}^{-1}$ at 15 minutes after the start of the recirculating perfusion. Flow was allowed to continue at this level for 1 minute. At time points 2 and 12 minutes $40 \mu \mathrm{l} 0.1 \mathrm{mM} \mathrm{CaCl}$ was added to the perfusion buffer. At the end of the perfusion period, the heart was removed from the cannula, transferred to a Petri dish and carefully 
opened using forceps. The opened heart was incubated with $10 \mathrm{ml}$ perfusate and $10 \mathrm{ml}$ medium $B$ (medium A supplemented with $0.2 \mathrm{mM} \mathrm{Ca}^{2+}$ and $2 \%$ $\mathrm{BSA})$ for 10 minutes in a shaking waterbath $\left(37^{\circ} \mathrm{C}, 180 \mathrm{rev} / \mathrm{min}\right)$ (HT Infors, model Aquatron, Bottmingen, Switzerland). The heart was subsequently transferred to a Petri dish and was further dissected with forceps. After dissection, the suspension was transferred to an Erlenmeyer flask and placed in a shaking waterbath $\left(37^{\circ} \mathrm{C}, 180 \mathrm{rev} . / \mathrm{min}\right)$ for 5 minutes while the $\mathrm{Ca}^{2+}$ concentration was increased with steps of $200 \mu \mathrm{M}$ to $1 \mathrm{mM}$. Next, cell suspension was filtered through a $0.2 \mathrm{~mm}$ nylon mesh and cardiomyocytes were pelleted by centrifugation ( $2 \mathrm{~min}, 17 \mathrm{~g}$ ). The cell pellet was resuspended in medium $C$ (medium A supplemented with $1 \mathrm{mM} \mathrm{Ca}^{2+}$ and $2 \% \mathrm{BSA}$ ) and centrifuged ( $2 \mathrm{~min}, 23 \mathrm{~g}$ ), and this procedure was repeated once. The cell pellet was resuspended in $20 \mathrm{ml}$ medium $C$ and transferred to a $50 \mathrm{ml}$ conical tube. Cardiomyocytes were allowed to rest for 1.5 hours under mild rotation. Prior to the start of the metabolic studies, cells were washed and resuspended in medium $C$.

At the end of the metabolic studies, viability of the cardiomyocytes was assessed by determining the percentage of rod-shaped cells. Furthermore, cellular wet weight was obtained by centrifugation in a micro centrifuge and subsequent removal of the supernatant from samples taken at the end of the performed experiments. All solutions used during the experiment were continuously gassed $\left(\mathrm{O}_{2}: \mathrm{CO}_{2}, 95 \%: 5 \%\right)$.

\section{Preparation of palmitate:BSA complex}

To prepare a stock solution of palmitate-BSA complex, $100 \mu \mathrm{Ci}$ $\left[1{ }^{14} \mathrm{C}\right]$ palmitate and either 1.8 or $3.6 \mathrm{mM}$ palmitate in $10 \mathrm{ml} 100 \%$ ethanol, were mixed with water containing $\mathrm{KOH}$ (1.5 times the amount of palmitate on molar basis). After evaporation of ethanol at $45^{\circ} \mathrm{C}$ under nitrogen, the saponified palmitate was added to $40 \mathrm{ml}$ medium A supplemented with $2.5 \%$ BSA. Prior to incubation, the stock solution was diluted 4.5 fold with medium A supplemented with $1.0 \mathrm{mM} \mathrm{CaCl}_{2}$.

\section{Palmitate uptake rate}

Rate of palmitate uptake was determined during 3 minutes as described previously ${ }^{14}$. In short, a $2.0 \mathrm{ml}$ suspension of freshly isolated cardiomyocytes was incubated in a capped glass vial $\left(\mathrm{O}_{2}: \mathrm{CO}_{2}, 95 \%: 5 \%\right)$ in the absence or presence of ketone bodies, in a shaking waterbath $\left(37^{\circ} \mathrm{C}, 180 \mathrm{rev} . / \mathrm{min}\right)$ 
(HT infors, model Aquatron, Bottmingen, Switzerland). After thermal equilibration, $0.5 \mathrm{ml}$ of labelled palmitate ( 80 or $160 \mu \mathrm{M}$ final concentration) was added and incubation proceeded for 3 minutes. Next, $2.0 \mathrm{ml}$ of the incubation mixture was transferred to a tube containing $8.0 \mathrm{ml}$ ice-cold stop solution. Correction for extracellular radioactivity was performed according to Luiken and co-workers ${ }^{12}$. Uptake experiments were performed in triplicate for each condition tested.

\section{Palmitate oxidation rate}

The rate of palmitate oxidation was determined in the presence or absence of ketone bodies during 30 minutes as described previously ${ }^{14}$. The reaction was started by addition of $\left[1-{ }^{14} \mathrm{C}\right]$ palmitate to the capped glass vial. After termination of the reaction, production of ${ }^{14} \mathrm{CO}_{2}$ was measured after base trapping in $\mathrm{NaOH}$. The obtained ${ }^{14} \mathrm{CO}_{2}$ values were corrected for ${ }^{14} \mathrm{CO}_{2}$ trapped in vials supplemented with $\left[1-{ }^{24} \mathrm{C}\right]$ palmitate but in the absence of cardiomyocytes in the incubation medium. Thereafter, this value was normalized on $\mathrm{mg}$ wet weight of cardiomyocytes and corrected for the percentage of non rod-shaped cells. Oxidation experiments were performed in triplicate for each condition tested.

\section{Incorporation of palmitate into intracellular lipids}

A $2.0 \mathrm{ml}$ suspension of cardiomyocytes was incubated in a capped glass vial in the absence or presence of ketone bodies, in an Aquatron shaking waterbath $\left(37^{\circ} \mathrm{C}, 180 \mathrm{rev} . / \mathrm{min}\right)$. Reaction was started by addition of $\left[1{ }^{14} \mathrm{C}\right]$ palmitate. After 30 minutes reaction was stopped according to Luiken and colleagues ${ }^{12}$. Cells were pelleted by centrifugation $\left(2 \mathrm{~min}, 60 \mathrm{~g}, 4^{\circ} \mathrm{C}\right)$ and washed twice with $5.0 \mathrm{ml}$ ice-cold stop solution. The pellet was solubilized in buffer containing (in mM), 50 Tris- $\mathrm{HCl} \mathrm{pH} 7.6,150 \mathrm{NaCl}, 5$ EDTA, and $1 \%$ $(w / v)$ Triton X-100. Lipids were extracted with chloroform/methanol and separated with thin layer chromatography ${ }^{11}$. The lipid spots corresponding to triacylglycerol (TG), phospholipids (PL), and FA were scraped from the plate and the amount of radioactivity was determined with a liquid scintillation counter. Incorporation experiments were performed in duplicate for each condition tested. 


\section{Choice of substrate concentrations}

Final extracellular concentrations of $80 \mu \mathrm{M}$ and $160 \mu \mathrm{M}\left[1{ }^{14} \mathrm{C}\right]$ palmitate were used. They correspond with the interstitial concentrations of FA in healthy and diabetic rats, respectively, taking into account that the interstitial FA concentration is approximately $60 \%$ of the arterial FA level ${ }^{15}$. These FA conditions were combined with varying concentrations of ACAC, $3 \mathrm{HB}$, or a combination of both ketone bodies. In general, in STZ-treated rats plasma concentration of ketone bodies is on the order of 3 to $6 \mathrm{mM}^{16,17}$ with a ratio of $3 \mathrm{HB}$ to $A C A C$ of $2: 1^{16}$. Since $A C A C$ was added to the incubation medium as lithium salt, the effect of $3 \mathrm{mM} \mathrm{Li}$ ( $(\mathrm{LiCl})$ was tested on FA uptake, oxidation, and deposition of label in the various lipid pools. No effect of $\mathrm{Li}^{+}$on FA handling was found (data not shown).

\section{Materials}

$\left[1 .{ }^{14} \mathrm{C}\right]$ Palmitic acid was obtained from NEN Life Science Products (Boston, MA, USA). Collagenase type 2 (LS04176) from Worthington (Lakewood, NJ, USA), phloretin, Bovine Serum Albumin fraction V (A4503), streptozotocin, $\mathrm{LiCl}$, acetoacetic acid (lithium salt), DL-B-hydroxybutyric acid, palmitic acid, and 2,3-butanedione monoxime from Sigma (St. Louis, MO, USA).

\section{Statistics}

Results were obtained from at least four different cardiomyocyte isolations and are presented as means \pm SD. Analysis of experiments within one group was performed with Two-tailed Student's $t$ tests. Comparison between groups was performed with the one-way analysis of variance (ANOVA). In case the $F$ ratio obtained indicated that significant differences between groups were present, a two-tailed Student's $t$ test for unpaired data was carried out, applying Bonferroni's adjustment for multiple comparison ${ }^{1.8}$. For all analyses, the level of significance was set at 0.05 . 


\section{Results}

\section{General characteristics of STZ-induced diabetic rats}

Body weight of the diabetic rats ( $301 \pm 49 \mathrm{~g}$ ) was significantly lower than that of controls $(394 \pm 18 \mathrm{~g})$. Diabetic plasma FA levels were significantly higher than control ( $265 \pm 88$ versus $134 \pm 59 \mu \mathrm{M})$. Diabetic blood glucose concentrations were significantly higher than control, $20.4 \pm 6.5$ and $9.1 \pm 1.0 \mathrm{mM}$, respectively.

Tablle 6.1 Initial paimitate uptake rate in control and diabetic cardiamyocytes

\begin{tabular}{|c|c|c|c|}
\hline \multirow[b]{2}{*}{ Palmitate] $(\mu \mathrm{M})$} & \multirow[b]{2}{*}{ Ketone bodies } & \multicolumn{2}{|c|}{ Initial uptake (nmol.g wet weight $\left.{ }^{-1} \cdot 3 \mathrm{~min}^{-1}\right)$} \\
\hline & & control & diabetic \\
\hline \multirow[t]{4}{*}{80} & - & $35.2 \pm 4.8$ & $40.1 \pm 7.6$ \\
\hline & $3 \mathrm{mMACAC}$ & $33.4 \pm 3.9$ & $39.3 \pm 9.0$ \\
\hline & 3. $\mathrm{mM} 3 \mathrm{HB}$ & $36.0 \pm 8.0$ & $41.2 \pm 9.4$ \\
\hline & $6 \mathrm{mM}$ combination & $36.0 \pm 5.0$ & $41.4 \pm 12.8$ \\
\hline \multirow[t]{4}{*}{160} & - & $54.8 \pm 5.0^{*}$ & $64.0 \pm 13.8^{*}$ \\
\hline & $3 \mathrm{mMAcAc}$ & $55.3 \pm 8.4^{*}$ & $60.2 \pm 14.0^{*}$ \\
\hline & $3 \mathrm{mM} 3 \mathrm{HB}$ & $60.7 \pm 7.6^{*}$ & $71.5 \pm 14.2^{*}$ \\
\hline & $6 \mathrm{mM}$ combination & $64.0 \pm 10.1^{*}$ & $70.1 \pm 27.5^{*}$ \\
\hline
\end{tabular}

Data are expressed as means \pm SD $(n=5)$. Asterisk indicates significantly different from the value of the corresponding incubation with $80 \mu \mathrm{M}$ palmitate $(p<0.05)$. Statistical analysis revealed that the higher mean values in diabetic cardiomyocytes as compared to corresponding controls did not reach the level of significance. (-) means in the absence of ketone bodies; ACAC refers to acetoacetate; $3 \mathrm{HB}$ to 3 - $\beta$-hydroxybutyrate; $6 \mathrm{mM}$ combination refers to a mixture of $3 \mathrm{HB}(4 \mathrm{mM})$ and $\mathrm{ACAC}(2 \mathrm{mM})$. The final incubation medium contained (in $\mathrm{MM}$ ) $\mathrm{NaCl}(115), \mathrm{KCl}(2.6), \mathrm{KH}_{2} \mathrm{PO}_{4}(1.2), \mathrm{MgSO}_{4}(1.2), \mathrm{NaHCO}_{3}$ (10), HEPES (10), glucose (11), $\mathrm{BSA}(0.3), \mathrm{pH} 7.4$, palmitate and ketone body concentration als indicated.

\section{Initial palmitate uptake rate}

There was no difference in the initial uptake rate of palmitate between control and diabetic cardiomyocytes at either normal $(80 \mu \mathrm{M})$ or elevated $(160 \mu \mathrm{M})$ palmitate concentrations (table 6.1). However, increasing the palmitate concentration from 80 to $160 \mu \mathrm{M}$ significantly enhanced its uptake. The percentage of increase did not differ between control and diabetic cardiomyocytes, being on the average $56 \%$ and $59 \%$, respectively. Ketone bodies did not affect the initial uptake rate of FA in either control or diabetic cardiomyocytes, irrespective of the palmitate concentration. 
Figure 6:1 Influence of ketone bodies on the rate of FA oxidation
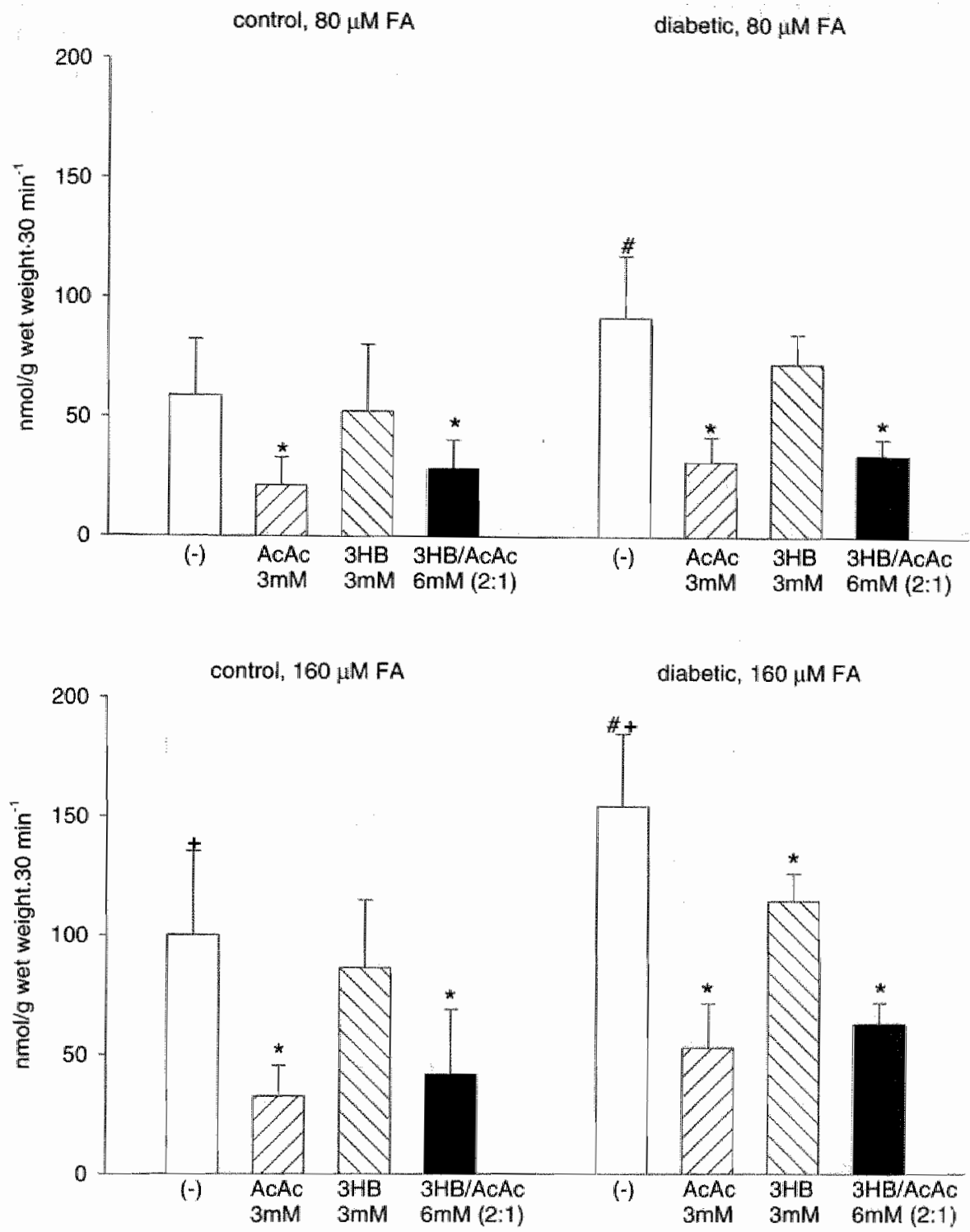

Cardiomyocytes derived from contral and diabetic rats were incubated with $\left[1{ }^{1.4} \mathrm{C}\right]$ palmitate for 30 minutes. See for further details legends to table 6.1 . AcAc to acetoacetate $(3 \mathrm{mM}) ; 3 \mathrm{HB}$ to 3 - $\beta$-hydroxybutyrate $(3 \mathrm{mM}) ; 6 \mathrm{mM}$ combination means a mixture of $3 \mathrm{HB}(4 \mathrm{mM})$ and $\mathrm{ACAC}$ (2 $\mathrm{mM}$ ). Data are expressed as mean $\pm S D(n=6)$. $p<0.05^{*}$ versus corresponding $(-)$; \# control versus corresponding diabetic; + normal FA versus corresponding high FA. 


\section{Palmitate oxidation rate}

The rate of palmitate oxidation at $80 \mu \mathrm{M}$ palmitate, in the absence of ketone bodies, is about $56 \%$ higher in diabetic cardiomyocytes than in those of control ( $p<0.05$ ) (figure 6.1). Increasing the palmitate concentration from 80 to $160 \mu M$ resulted in a $70 \%$ increase in oxidation rate in control cardiomyocytes $(p<0.05)$. The percentage increase in diabetic cardiomyocytes was comparable (68\%). Addition of $6 \mathrm{mM}$ ketone bodies (3HB/AcAc, 2:1) to control cardiomyocytes significantly decreased the oxidation rate, both at normal and elevated palmitate concentrations, by 51 and $58 \%$, respectively. Comparable inhibitory effects were seen in diabetic cardiomyocytes. Figure 6.1 also shows the differential effect of $3 \mathrm{HB}$ and $\mathrm{ACAC}$. When cardiomyocytes were exposed to $3 \mathrm{HB}(3 \mathrm{mM})$, the inhibitory effect was insignificant under all conditions analysed. In contrast, exposure to $3 \mathrm{mM}$ AcAc substantially inhibited palmitate oxidation to a comparable extent in control and diabetic cardiomocytes, at both palmitate concentrations.

\section{Influence of varying concentrations of ketone bodies on FA oxidation}

Figure 6.2 shows that palmitate oxidation can be suppressed to approximately $30 \%$ of its maximal rate by AcAc. This is true for cardiomyocytes derived from control and diabetic animals. The maximal percentage of inhibition was found to be independent from the two palmitate concentrations applied (figure 6.2). Half-maximum inhibition is reached at 0.3-0.5 $\mathrm{mM} \mathrm{AcAc}$ and maximum inhibition at $2 \mathrm{mM} \mathrm{ACAc}$ and higher. ACAC is therefore a highly potent inhibitor of cardiomyocyte $F A$ oxidation, and the sensitivity to ACAC hardly differs between control and diabetic cells. The findings in figure 6.2 also indicate that it is mainly $A C A C$ that causes the inhibitory effect of the mixture of $A C A C$ and $3 \mathrm{HB}$, supporting the results shown in figure 6.1 .

\section{Incorporation of labelled palmitate in various intracellular lipid
pools}

In control cardiomyocytes, incubated under normal conditions (80 $\mu \mathrm{M}$ palmitate, no ketone bodies) incorporation of labelled palmitate in the cellular PL, TG and FA pool amounted to $0.27 \pm 0.14,1.46 \pm 0.80$ and $0.07 \pm 0.05 \mathrm{nmol} \cdot \mathrm{g}$ wet weight ${ }^{-1} \cdot 30 \mathrm{~min}^{-1}$, respectively. 
Figure 6.2 Influence of varying concentrations of ketone bodies on the rate of FA oxidation
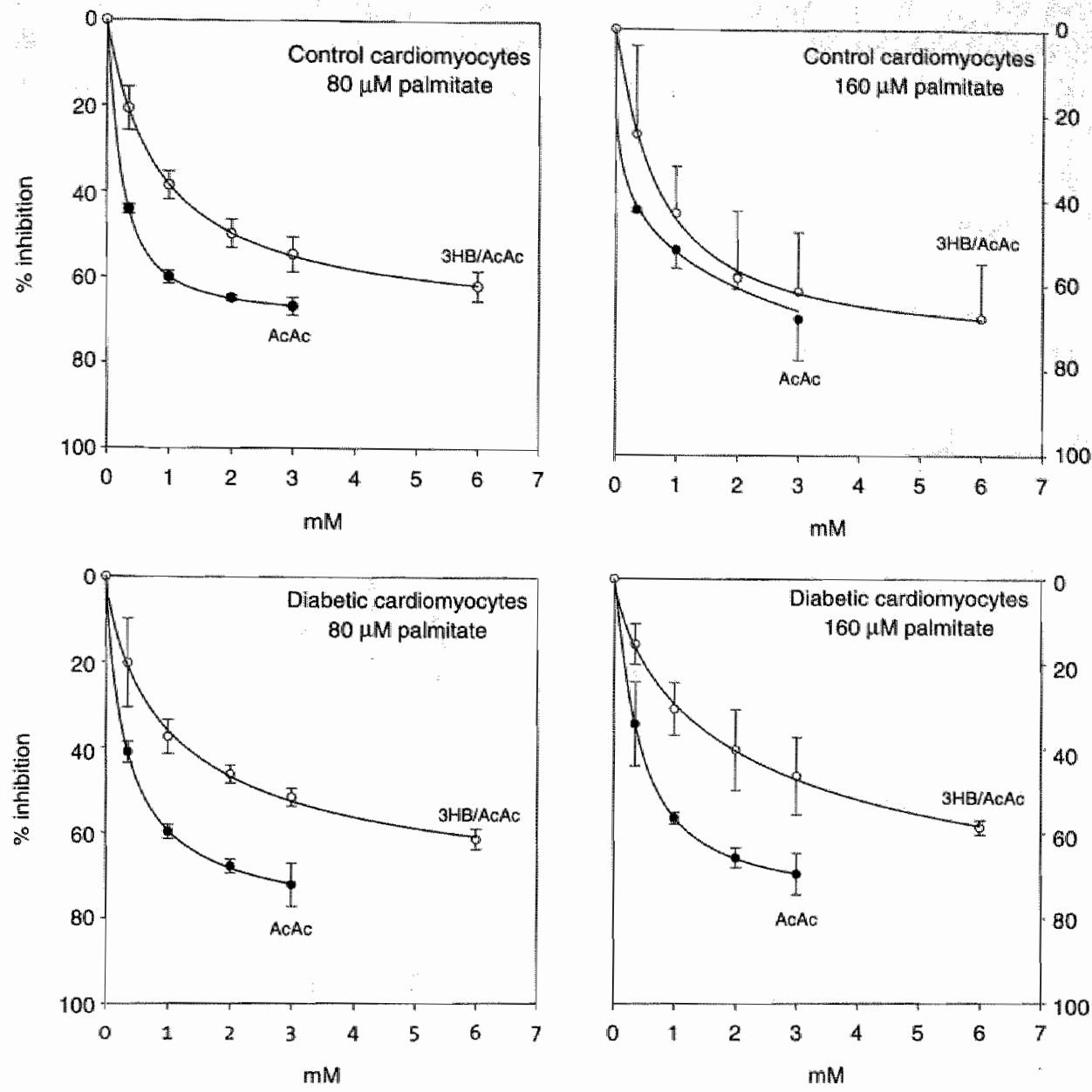

Control and diabetic cardiomyocytes were incubated with either 80 or $160 \mu \mathrm{M}$ palmitate, both with varying concentrations of ketone bodies, for 30 minutes. See for further detalls legends to table 1. Black circles $=A C A C ;$ White circles $=3 H B / A C A C(2: 1)$. Data are expressed as mean \pm SD $(n=4)$.

In diabetic cardiomyocytes, incubated under diabetic conditions (160 $\mu \mathrm{M}$ palmitate, $3 \mathrm{mM}$ AcAc) substantial higher amounts of labelled palmitate were incorporated in the PL, TG and FA pool, i.e. $0.69 \pm 0.32,5.15 \pm 3.02$ and $0.19 \pm 0.18 \mathrm{nmol} \cdot \mathrm{g}$ wet weight ${ }^{-1} \cdot 30 \mathrm{~min}^{-1}$. However, due to a relatively high degree of variation between the individual experiments, the increase in the deposition of palmitate into the various lipid pools in the diabetic cells did not reach the level of significance. AcAc, was set at 1.0. To evaluate the effect of varying the ambient palmitate concentration and the addition of AcAC to 
the incubation medium, the values obtained in either control or diabetic cells incubated in the presence of $80 \mu \mathrm{M}$ palmitate, in the absence of This procedure enabled us to use the cells as their own control. Raising the concentration from 80 to $160 \mu \mathrm{M}$ tended to increase the incorporation of palmitate in the PL and $T G$ pool of control cells (figure 6.3). The increased deposition of label in the PL, TG and FA pool of diabetic cardiomyocytes was highly significant when the extracellular palmitate concentration was increased from 80 to $160 \mu \mathrm{M}(\mathrm{p}<0.05)$.

Figure 6.3 Deposition of radiolabelled palmitate in various lipid pools in control and diabetic cardionyocytes
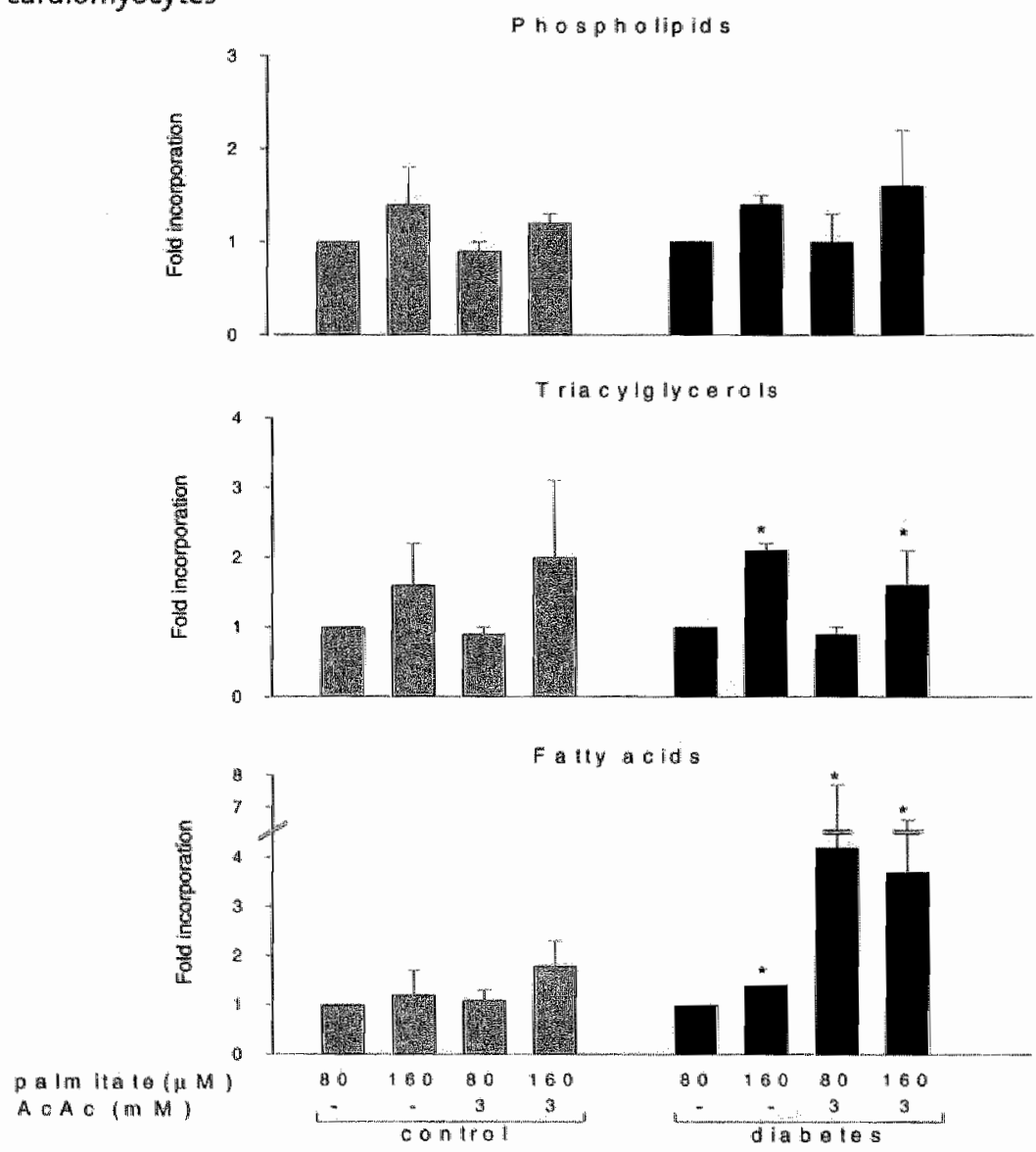

After incubation for 30 minutes with radiolabelled palmitate, lipids were extracted and subjected to TLC. Data are presented relative to the values obtained in control and diabetic cardiomyocytes, respectively, incubated in the presence of $80 \mu \mathrm{M}$ palmitate without ketone bodies. See for further details legends to table 6.1. Asterisk indicates significantly different from the corresponding incubation with $80 \mu \mathrm{M}$ palmitate, without ketone bodies. Data are expressed as mean $\pm S D(n=4)$. 
Exposure of cardiomyocytes, either derived from control or diabetic hearts; to $3 \mathrm{mM} \mathrm{ACAC}$ at $80 \mu \mathrm{M}$ palmitate did not affect the incorporation of palmitate in the PL and TG pool. The FA pool in diabetic cardiomyocytes incubated in the presence of $80 \mu \mathrm{M}$ palmitate showed a significant expansion when exposed to $3 \mathrm{mM} \mathrm{AcAc}$. This effect was not seen in control cardiac muscle cells. When the concentration of palmitate was increased from 80 to $160 \mu \mathrm{M}$ in the incubation medium of control or diabetic cells, exposed to $3 \mathrm{mM} \mathrm{AcAc}$, the deposition of labelled palmitate tended to increase (control) or significantly increased (diabetic cells) in the PL and TG pool. Since this pattern was also observed in cells incubated in the absence of ACAC, increased deposition of labelled FA in the esterified lipid pools is mainly caused by increased availability of FA rather than by a modulating effect of ACAC. The same conclusion holds for the FA pool in control cardiomyocytes. In contrast, in diabetic cardiomyocytes, bulk accumulation of labelled palmitate in the FA pool seems to be mainly caused by the presence of ACAC in the incubation medium.

\section{Discussion}

The present observations indicate that ketone bodies, in particular AcAC, affect FA handling in the cardiac muscle cell. This finding is of interest because it allows one to fully appreciate the changes in cardiac FA utilization in the diabetic heart, since the circulating concentration of ketone bodies is substantially increased in this pathophysiological condition. AcAc causes a mismatch between FA uptake (not affected by ACAC, but increased due to enhanced supply) and FA oxidation (significantly inhibited by ACAC) when diabetic cardiomyocytes, derived from STZ-treated rats and incubated under diabetic conditions, i.e. $160 \mu \mathrm{M}$ palmitate, $3 \mathrm{mM} \mathrm{AcAc}$, were compared with control cardiomyocytes, incubated under normal conditions, i.e. $80 \mu \mathrm{M}$ palmitate, no ketone bodies. This mismatch most likely explains the accumulation of lipids, FA and $\mathrm{TG}_{\text {, }}$ in the diabetic heart in situ. Moreover, the present findings are challenging the current paradigm that FA oxidation is enhanced in the diabetic heart, since this notion is based on experiments performed on isolated hearts perfused with media devoid of ketone bodies. 


\section{General background}

Earlier findings in hearts isolated from STZ-treated rats and immediately freeze-clamped for tissue lipid analysis indicated a 4.5 fold accumulation of FA in the diabetic heart, while blood FA levels were enhanced only two-fold ${ }^{11}$. Accumulation of FA in cardiac tissue, also reported by Heyliger and colleagues "strongly suggests a mismatch between the uptake of extracellular FA and their intracellular utilization. A common feature in patients suffering from diabetes and in experimental diabetic animals is an increased circulatory level of ketone bodies, $A C A C$ and $3 \mathrm{HB}{ }^{20}$. This increase is most striking in diabetic ketoacidosis, a major complication of type 1 diabetes. Elevated levels of ketone bodies have been also observed in poorly controlled type 2 diabetes, chronic cardiac failure and during the consumption of high fat diet $21-24$. Pioneering studies of Randle and colleagues have shown that ketone bodies serve as alternative substrates for energy conversion in cardiac muscle ${ }^{20}$. Considering the enhanced availability of ketone bodies in the diabetic state, it is likely that the presence of those substances interfere with myocardiallipid metabolism.

To fulfil cardiac energy requirements two main nutrients, FA and glucose, are continuously supplied to the heart, extracted from the extracellular compartment and oxidized in the mitochondrial matrix to regenerate the myocytal ATP pool. Under normal circumstances, oxidation of plasma-borne FA contributes up to $60-70 \%$ of energy conversion in the healthy heart ${ }^{8}$. In the diabetic heart fuel selection is significantly changed, but the direction and magnitude of the alterations in cardiac FA consumption appear to differ greatly between studies dealing with this subject matter ${ }^{3}$. These considerations prompted us to investigate the effect of ketone bodies on FA handling by cardiac muscle cells derived from STZ-treated rats.

\section{Initial palmitate uptake rate}

The present findings clearly indicate that the rate of palmitate uptake by isolated cardiomyocytes is not changed in the diabetic state when the cells were exposed to normal extracellular palmitate concentrations, i.e. $80 \mu \mathrm{M}$. Elevation of the concentration to $160 \mu \mathrm{M}$ (diabetic conditions) caused a significant and comparable increase in the initial rate of palmitate uptake both in diabetic and control cardiomyocytes, indicating that, under the present conditions, trans-sarcolemmal FA transport is not altered in diabetic cells. This result might be surprising since earlier studies showed that STZtreatment resulted in an increase in the myocardial content of proteins 
known to facilitate FA uptake, including FAT/CD 36 ${ }^{25}$ 26. A possible explanation is that the increased amount of FAT/CD 36 is stored in the cytoplasmic compartment rather than incorporated into the plasma membrane.

The fact that neither $\mathrm{ACAC}$ nor $3 \mathrm{HB}$, present in the incubation medium, altered the uptake rate of palmitate in cardiomyocytes indicates that the mechanisms underlying the unidirectional influx of FA across the sarcolemma are insensitive to the presence of ketone bodies in the interstitial compartment. Since diabetic cardiomyocytes in vivo are exposed to both elevated FA levels and enhanced concentrations of ketone bodies the conclusion can be drawn that diabetic cardiomyocytes take up higher amounts of FA from their surroundings than control, merely because the extracellular FA availability is increased (figure 6.4).

Figure 6.4 Initial uptake and oxidation of palmitate by control and diabetic cardiomyocytes
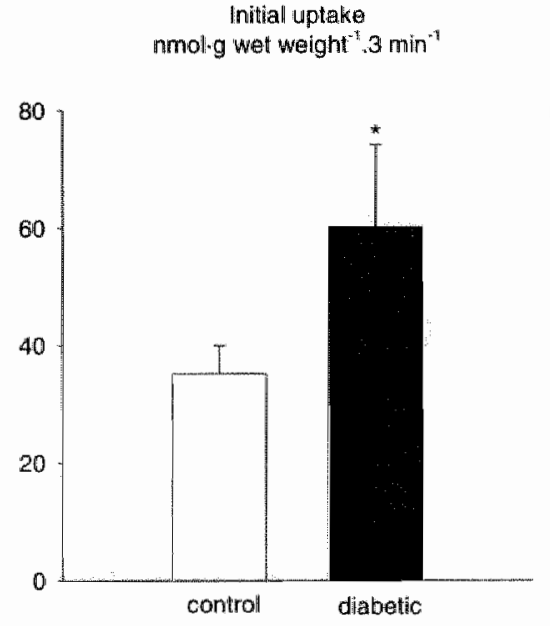

80

$\$ 60$

3

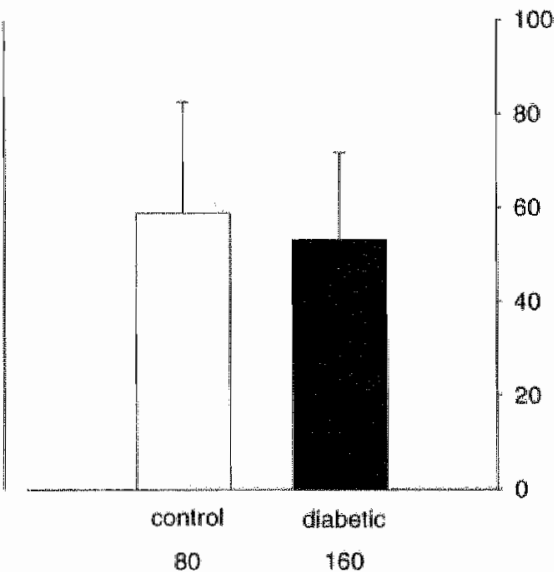

3

This figure is a compilation of data shown in table 6.1 and figure 6.1 Control cardiomyocytes were incubated for either 3 minutes (initial uptake) or 30 minutes (oxidation) under normal conditions, i.e. $80 \mu \mathrm{M}$ palmitate, in the absence of acetoacetate (ACAC); diabetic cardiomyocytes were incubated during similar time intervals under diabetic conditions, i.e. $160 \mu \mathrm{M}$ palmitate in the presence of $3 \mathrm{mM} \mathrm{ACAC}$. Data are expressed as mean $15 \mathrm{D}(n=5-6)$. Asterisk indicates a statistically significant difference between control and diabetic cells. 


\section{Palmitate oxidation rate}

The rate of palmitate oxidation was found to be significantly higher in cardiomyocytes isolated from diabetic hearts than in cardiomyocytes from control hearts when incubated under comparable, normal conditions ( $80 \mu \mathrm{M}$ palmitate, no ketone bodies). These findings support some earlier observations in isolated rat hearts, namely that the rate of FA oxidation is increased in hearts obtained from diabetic animals ${ }^{4,}{ }^{6}$. Increasing the extracellular palmitate concentration from 80 to $160 \mu \mathrm{M}$ enhanced the FA oxidation rate about $70 \%$ both in control and diabetic cardiomyocytes. Comparing control cells at normal ambient FA levels with diabetic cardiomyocytes subjected to diabetic FA concentrations revealed that the rate of palmitate oxidation is approximately 3 times higher in the latter (figure 6.1). However, this picture substantially changes when ketone bodies were added to the incubation medium to mimic the diabetic conditions as much as possible. Co-incubation of diabetic cardiac muscle cells with $160 \mu \mathrm{M}$ palmitate and $3 \mathrm{mM} \mathrm{AcAc}$ inhibited palmitate oxidation by approximately $65 \%$. The resulting oxidation rate $\left(53.2 \pm 18.5 \mathrm{nmol} \cdot \mathrm{g}\right.$ wet weight $\left.{ }^{-1} \cdot 30 \mathrm{~min}^{-1}\right)$ was not significantly different from that measured in control cells, incubated in control conditions $\left(58.9 \pm 23.6 \mathrm{nmol} \cdot \mathrm{g}\right.$ wet weight ${ }^{-1} .30 \mathrm{~min}^{-1} ; 80 \mu \mathrm{M}$ palmitate, no ketone bodies) (figure 6.4). It is noteworthy that the inhibitory effect of ketone bodies on myocyte FA oxidation is almost exclusively caused by $A C A C$, since the effect of the reduced counterpart, $3 \mathrm{HB}$, was found to be negligible. The lack of effect of $3 \mathrm{HB}$ is remarkable, considering that both $3 \mathrm{HB}$ and $A C A C$ can be used as oxidizable substrate by the heart ${ }^{20}$. At present no conclusive explanation can be offered for this intriguing observation, although differences in redox state in the cardiomyocytes exposed to either ACAC or $3 \mathrm{HB}$ should be considered. In this respect, earlier findings of isales and colleagues are worth mentioning, as they also observed differential effects of $3 \mathrm{HB}$ and $\mathrm{ACAC}$, namely on the regulation of growth factors in brain endothelial cells ${ }^{27}$.

Detailed analysis of the inhibitory effect of AcAc on cardiomyocyte palmitate oxidation revealed that, both in control and diabetic cells, AcAc is a potent inhibitor of palmitate oxidation. The maximal degree of inhibition in both cell types was on the order of $70 \%$, irrespective of the concentration of palmitate in the extracellular fluid. Since ketone bodies are permeant to cells via the $\mathrm{H}^{*}$ monocarboxylate co-transporter ${ }^{28-30}$, transport limitations of ketone bodies through this protein-mediated process could therefore contribute to the inability to depress FA oxidation any further.

Half-maximal inhibition was obtained at about $0.3-0.5 \mathrm{mM} \mathrm{ACAC}$, indicating that, on the one hand, FA oxidation by cardiomyocytes is highly 
sensitive to ACAC in the surrounding medium since this relatively low concentration of ACAC is readily reached under a variety of conditions ${ }^{34}$ and, on the other, that the sensitivity to AcAc did not differ between diabetic and healthy cardiomyocytes. The latter indicates that cardiomyocytes in diabetic hearts do not adjust to chronically elevated levels of ketone bodies by altering their sensitivity towards the inhibitory action of these compounds. This kind of adjustment might have been expected since previous observations by Grinblat and colleagues ${ }^{32}$ and Kante and co-workers ${ }^{33}$ showed that the expression and activity of two enzymes involved in ketone body handling, namely 3- 3 -hydroxybutyrate dehydrogenase and 3-oxoacidCoA transferase, are significantly decreased in the diabetic heart as compared to controls. Obviously, not merely the intracellular conversion but also other, as yet unidentified properties may be involved in the inhibitory action of ketone bodies on cardiac FA oxidation.

\section{Incorporation of palmitate in cellular lipid pools}

In general, the amount of labelled palmitate sequestered in the esterified lipid pool (TG and PL) depended on the extracellular FA concentration. Increasing the supply of palmitate resulted in a higher degree of esterification, both in control and diabetic cardiomyocytes. AcAc exerted no significant effect on the rate of palmitate esterification under these conditions. The observation that the TG content is enhanced in the diabetic heart in situ ${ }^{34}$ is supported by the present findings. It is noteworthy that the increased supply of extracellular FA, rather than the presence of ketone bodies, is instrumental in the enhanced deposition of paimitate into the intracellular TG pool (figure 6.3). Previous studies also indicated that ketone bodies are able to inhibit lipolysis ${ }^{35}$, which may contribute to the net expansion of the TC pool in the diabetic heart in situ. The present findings, however, do not support this notion, since (additive) effects of ACAC on the incorporation of palmitate into the intracellular TG pool were absent.

The present study clearly shows that in diabetic cardiomyocytes ACAC increases the intracellular level of non-esterified palmitate, both at the extracellular concentration of 80 and $160 \mu \mathrm{M}$ palmitate (figure 6.3). It is noteworthy that the 4-fold increase in deposition of labelled palmitate in the cellular FA pool matches very well with the 4.5-fold increase in the FA content of diabetic hearts in situ ${ }^{11}$. Collectively, the present findings strongly suggest that accumulation of FA in cardiac tissue is caused by a combination of two separate changes in the diabetic cardiomyocyte: the initial uptake rate of FA by diabetic cardiomyocytes is enhanced, due to the increased 
supply of extracellular pallmitate, on the one hand and the inhibitory action of ketone bodies, in particular ACAC, on the intracellular rate of FA oxidation, on the other. This notion is illustrated in figure 6.4, summarizing data shown in table 6.1 and figure 6.1. It should be emphasized, however, that the present data are obtained in resting cardiac muscle cells. It is of interest to explore how at enhanced workload (e.g. the beating heart) circulating ketone bodies interact with cardiac FA handling.

\section{Possible implications of the present findings}

One may speculate on the pathophysiological consequences of chronically elevated FA levels inside the cardiomyocytes of the diabetic heart. Pioneering studies of Feuvray and colleagues have shown that accumulation of lipotoxic FA and their intermediates are associated with mechanical dysfunction and cell damage in diabetic hearts subjected to ischemia ${ }^{36}$. Furthermore, other studies indicated that FA at elevated concentrations exert cytotoxic effects, including aberrations in signal transduction cascades ${ }^{37-39}$. More recent observations by $\operatorname{Van}$ der Lee and colleagues ${ }^{10}$ and others ${ }^{40-42}$ have convincingly shown that chronic exposure of cardiomyocytes to FA modulate the expression of a panel of cardiac enzymes involved in carbohydrate and fatty acid handling. The down-regulation of hexokinase II and the upregulation of long-chain acyl-CoA dehydrogenase, especially, may explain the decline in glucose utilization and enhanced FA oxidation commonly observed in isolated hearts obtained from STZ-treated diabetic rats ${ }^{10}$.

The present findings, however, challenge the current paradigm that FA oxidation is enhanced in the intact diabetic heart ${ }^{43.44}$. The latter notion is based on experimental findings showing a significant increase in the oxidation rate of radiolabelled palmitate by hearts isolated from STZ-treated rats ${ }^{45}$. Results of other studies, however, do not support these findings. The rate of FA oxidation was found to be decreased in hearts from spontaneously diabetic rats ${ }^{44}$, and unchanged in hearts obtained from insulin-resistant obese rats ${ }^{46}$. Moreover, the utilization of FA by the hearts in vivo of diabetic swine was found to be not significantly different from control ${ }^{45}$, while the uptake and oxidation of iodine-labelled FA analogues by hearts of patients with impaired glucose tolerance was decreased?. Finally, cardiac FA uptake and oxidative utilization of patients suffering from type 1 and type 2 did not significantly differ from healthy controls?

Since the contrasting findings are most pronounced between isolated hearts (enhanced FA utilization) and intact hearts in situ (no changes or even a decline in FA uptake and/or oxidation) the regulatory role of other factors 
present in blood plasma, but not in buffers used in perfusion experiments on isolated hearts should be considered. These factors may be, among others, elevated blood concentration of ketone bodies in the intact experimental animal or subjects, suffering from diabetes.

The present findings might also have ramifications to other conditions associated with enhanced plasma ketone body levels, such as starvation, high fat diets, and cardiac failure. Under these conditions cardiac FA handling may be compromised by elevated exposure of the heart to circulating ketone bodies. 


\section{References}

1. Stearns, 5B, Tepperman, HM and Tepperman, J. Studies on the utilization and mobilization of lipid in skeletal muscles from streptozotocin-diabetic and control rats. J Lipid Res 20 : $654-662,1979$.

2. Wahren, J, Hagenfeldt, $L$ and Felig, P. Splanchnic and leg exchange of glucose, amino acids, and free fatty acids during exercise in diabetes mellitus. J Clin Invest 55: 1303-1314, 1975.

3. Owen, OE, Markus, $H_{*}$ Sarshik, $S$ and Mozzoli, $M$. Relationship between plasma an muscle concentrations of ketone bodies and free faaty acids in fed, starved and alloxan-diabetic states. Biochem J. 134: 499-506, 1973.

4. Christe, ME and Rodgers, RL. Cardiac glucose and fatty acid oxidation in the streptozotocin-induced diabetic spontaneously hypertensive rat. Hypertension 25: 235241, 1995 .

5. Rodrigues, $\mathrm{B}$ and $\mathbf{M C N e i l l ,} \mathbf{J H}$. The diabetic heart: metabolic causes for the development of a Cardiomyopathy. Cardiovasc Res 26:913-922, 1992.

6. Saddik, $M$ and Lopaschuk, CD. Triacylglycerol turnover in isolated working hearts of acutely diabetic rats. Can J Physiol Pharmacol 72: 1110-1119, 1994.

7. Turpeinen ${ }_{i 1}$ AK, Kulkka, JT, Vanninen, E and Uusitupa, MI. Abnormal myocardial kinetics of 1231-heptadecanoic acid in subjects with impaired glucose tolerance. Diabetologia 40 : 541-5.49, 1997.

8. Van der Vusse "GJ, Glatz, JF, Stam, HC and Reneman, RS. Fatty acid homeostasis in the normoxic and ischemic heart. Physiol Rev 72: 881-940, 1992.

9. Neely, JR and Feuvray, D. Metabolic products and myocardial ischemia. Am I Pathol 102: 282-291, 1981.

10. Van der Lee, KA, Vork, MM, De Vries, JE, Willemsen, PH, Glatz, JF, Reneman, RS, Van der Vusse, GJ and Van Bilsen, $M$. Long-chain fatty acid-induced changes in gene expression in neonatal cardiac riyocytes. J Lipid Res $41: 41-47,2000$.

11. Hasselbaink, DM, Roemen, TH and Van der Vusse, GJ. Determination of long-chain fatty acids, triacylglycerols and phospholipids by capillary gas chromatography in cardiac tissue and blood plasma of normal and diabetic rats. Anal Chim Acta 465: 351-357, 2002.

12. Luiken, J, Van Nieuwenhoven, FA, America, G, Van der Vusse, GJ and Glatz, JF. Uptake and metabolism of palmitate by isolated cardiac myocytes from adult rats: involvement of sarcolemmal proteins. J Lipid Res 38: 745-758., 1997.

13. Langendorf, 0 . Untersuchungen am uberlebenden saugethierherzen. Pflugers Archives fur die gesamte physiologie des menschen and der tiere 61: 291-332,1895.

14. Luiken, JJ, Willems, J, Van der Vusse, GJ and Glatz, JF. Electrostimulation enhances FAT/CD36 mediated long-chaim fatty acid uptake by isolated rat cardiac myocytes. Am J Physiol Endocrinol Metab 281: E704-712, 2001. 
15. Julien, P, Gaillis, L, Lepage, $M$ and Roy, PE. A comparison of fatty acid patterns of arterial plasma, pericardial fluid and cardiac lymph in dog: Artery 5: 37-44, 1979.

16. Charlton, JA, Thompson, $\mathrm{CJ}$ and Baylis, PH. Possible mechanisms responsible for the rise in plasma vasopressin associated with diabetic ketoacidosis in the rat. I Endocrinol 116: 343$348,1988$.

17. Kashiwaya, $Y$, King, MT and Veech, RL. Substrate signaling by insulin: a ketone bodies ratio mimics insulin action in heart. Am J Cardiol 80: 50A-64A, 1997.

18. Wallenstein, S, Zucker, $\mathrm{CL}$ and Fleiss, JL. Some statistical methods useful in circulation research. Circ Res 47: 1-9, 1980.

19. Heyliger, CE, Scarim, AL, Eymer, VP, Skau, KA and Powell, DM. Characteristics of the myocardial PM-FABP: effect of diabetes mellitus. Mol Cell Biochem 176: 281-286, 1997.

20. Randle, PJ, Newsholme, EA and Garland, PB. Regulation of glucose uptake by muscle. 8. Effects of fatty acids, ketone bodies and pyruvate, and of alloxan-diabetes and starvation, on the uptake and metabolic fate of glucose in rat heart and diaphragm muscies. Biochem / 93:652-665, 1964.

21. Edens, NK and Friedman, MI. Response of normal and diabetic rats to increasing dietary medium-chain triglyceride content. J Nutr 114: 565-573, 1984 .

22. Lommi, J, Koskinen, P, Naveri, H, Harkonen, $M$ and Kupari, $M$. Heart failure ketosis. $J$ Intern Med 242: 231-238, 1997.

23. Lommi, J, Kupari, $\mathbf{M}$ and Yki-Jarvinen, $\boldsymbol{H}$. Free fatty acid kinetics and oxidation in congestive heart failure. Am J Cardiol 81: 45-50, 1998.

24. Umpierrez, GE, Watts, NB and Phillips, LS. Clinical utility of beta-hydroxybutyrate determined by reflectance meter in the management of diabetic ketoacidosis. Diabetes Care 18: 137-138, 1995 .

25. Glatz, JF, van Breda, E, Keizer, HA, de Jong, YF, Lakey, JR, Rajotte, RV, Thompson, A, van der Vusse, GJ and Lopaschuk, GD. Rat heart fatty acid-binding protein content is increased in experimental diabetes. Biochem Biophys Res Commun 199: 639-646, 1994.

26. Pelsers, MM, Lutgerink, JT, Nieuwenhoven, FA, Tandon, NN, van der Vusse, GJ, Arends, JW, Hoogenboom, HR and Glatz, JF. A sensitive immunoassay for rat fatty acid translocase (CD36) using phage antibodies selected on cell transfectants: abundant presence of fatty acid translocase/CD36 in cardiac and red skeletal muscle and up regulation in diabetes. Biochem J 337: 407-414, 1999.

27. Isales, CM, Min, L and Hoffman, WH. Acetoacetate and beta-hydroxybutyrate differentially regulate endothelin-1 and vascular endothelial growth factor in mouse brain microvascular endothelial cells. I Diabetes Complications 13:91-97, 1999.

28. Poole, RC and Halestrap, AP. Transport of lactate and other monocarboxylates across mammalian plasma membranes. Am J Physiol 264: C761-782, 1993.

29. Wang, $X$, Levi, All and Halestrap, AP. Substrate and inhibitor specificities of the monocarboxylate transporters of single rat heart cells. Am J Physiol 270: H476-484, 1996. 
30. Zorzano, $A_{,}$Fandos, $C$ and Palacin, M. Role of plasma membrane transporters in muscle metabolism. Biochem J 349 Pt 3: 667-688, 2000.

31. Laffel, L. Ketone bodies: a review of physiology, pathiophysiology and application of monitoring to diabetes. Diabetes Metab Res Rev 15: 412-426, 1999.

32. Grinblat, L, Pacheco Bolanos, LF and Stoppani, AO. Decreased rate of ketone-body oxidation and decreased activity of D-3-hydroxybutyrate dehydrogenase and succinylCOA:3-0XO-acid COA-transferase in heart mitochondria of diabetic rats. Biochem I 240 : 49-56, 1986 .

33. Kante, A, Malki, MC, Coquard, $C$ and Latruffe, N. Metabolic control of the expression of mitochondrial D-beta- hydroxybutyrate dehydrogenase, a ketone body converting enzyme. Biochim Biophys Acta 1033: 291-297, 1990.

34. Paulson, DJ and Crass, MF, 3rd. Endogenous trilacylglycerol metabolism in diabetic heart. Am J Physiol 242: H1084-1094, 1982.

35. Larsen, TS and Severson, DL. Influence of exogenous fatty acids and ketone bodies on rates of lipolysis in isolated ventricular myocytes from normal and diabetic rats. Can $J$ Physiol Pharmacol 68: 1177-1182, 1990.

36. Feuvray, D, Idell-Wenger, JA and Neely, JR. Effects of ischemia on rat myocardial function and metabolism in diabetes. Circ Res 44: 322-329, 1979.

37. de Vries, JE, Vork, MM, Roemen, TH, de Jong, YF, Cleutjens, JP, Van der Vusse, GJ and Van Bilsen, M. Saturated but not mono-unsaturated fatty acids induce apoptotic cell death in neonatal rat ventricular myocytes. J Lipid Res 38: 1384-1394., 1997.

38. Listenberger, LL, Ory, DS and Schaffer, JE. Palmitate-induced Apoptosis Can Occur through a Ceramide-independent Pathway. I Biol Chem 276: 14890-14895., 2001.

39. Mallov, 5 . Role of calcium and free fatty acids in epinephrine-induced myocardial necrosis. Toxicol Appl Pharmacol 71: 280-287, 1983.

40. Barger, PM and Kelly, DP. PPAR signaling in the control of cardiac energy metabolism. Trends Cardiowäsc Med 10: 238-245, 2000.

41. Latruffe, $\mathbf{N}$ and Vamecq, J. Peroxisome proliferators and peroxisome proliferator activated receptors (PPARs) as regulators of lipid metabolism. Biochimie 79: 81-94, 1997.

4.2. Taegtmeyer, $H$. Genetics of energetics: transcriptional responses in cardiac metabolism. Ann Biomed Eng 28: 871-876, 2000.

43. Stanley, WC, Lopaschuk, GD and McCormack, JG. Regulation of energy substrate metabolism in the diabetic heart. Cardiovase Res 34: 25-33, 1997.

44. Lopaschuk, GD and Tsang, H. Metabolism of palmitate in isolated working hearts from spontaneously diabetic "BB" Wistar rats. Circ Res 61: 853-858, 1987.

45. Hall, JL, stanley, WC, Lopaschuk, GD, Wisneski, JA, Pizzurro, RD, Hamilton, CD and McCormack, JG. Impaired pyruvate oxidation but normal glucose uptake in diabetic pig heart during dobutamine-induced work. Am J Physial 271: H2320-2329, 1996.

46. Lopaschuk, GD and Russell, JC. Myocardial function and energy substrate metabolism in the insulin- resistant ICR:LA corpulent rat. IApp/ Physiol 71: 1302-1308, 1991. 


\section{Chapter 7}

Metabolic and genetic adaptations in the streptozotocin-treated rat heart

An explorative study 


\section{Abstract}

it is known that patients with diabetes mellitus have a higher rate of mortality than the general population. This higher mortality has been attributed, among others, to the development of diabetic cardiomyopathies. The precise mechanisms underlying the development of this diseased state are unclear. As diabetes is mainly a metabolic disorder, one can assume that alterations in myocardial metabolic properties contribute or cause the development of diabetic cardiomyopathy. To obtain more insight into metabolic remodelling of the diabetic heart, we examined the available substrates, hormone levels, cofactor content, enzyme activity, and mRNA levels under diabetic conditions. Studies were performed on intact hearts, isolated adult and neonatal cardiomyocytes.

\section{Introduction}

In essence diabetes mellitus can be classified as a disorder characterized by abnormal insulin secretion and/or resistance to the action of insulin. In the order of $10 \%$ of the diabetic patient population exhibit a profound lack of insulin (type-1 diabetes, insulin dependent diabetes mellitus), while the remaining patients suffer from varying degrees in the lack of action of insulin at the target organ (type-2 diabetes, non-insulin dependent diabetes mellitus). A major cause of death among patients with diabetes is malfunctioning of the heart caused by diabetes-induced cardiomyopathies.

The heart can be considered as an omnivorous organ, whereas circulating long chain fatty acids (FA) are the most prominent source of energy under normal conditions. However, in the diabetic state the concentration of substrates present in blood plasma significantly alters. The most prominent changes are the increases in glucose and FA. Besides these major changes, the concentration of substrates such as the triacylglycerols (TG) content and ketone body levels are also altered.

The changes in substrate availability may cause a shift in metabolic flux, which is likely to be involved in the adaptation of the heart to changes in its environment. The current paradigm considering energy metabolism in the diabetic heart, states that glucose oxidation is decreased and that FA oxidation is increased as compared to normal ${ }^{1,2}$. However, it still remains a matter of debate whether the paradigm is actually valid 3 .

Considering the chronic nature of diabetes mellitus, it is likely that this pathophysiological state induces a response that over time will lead to a variety of metabolic and/or genetic adaptations or maladaptations. This chapter will try to elucidate, in an explorative manner, the various metabolic 
and genetic changes occurring in the heart during diabetes and underlying mechanisms at various levels. First, the effect of chronic diabetes (4-5 weeks after streptozotocin treatment) on the cardiac substrate content and levels of coenzyme A and carnitine (both important cofactors in cardiac energy conversion) was monitored. Second, the activity of a set of enzymes playing a key role in cardiac energy conversion (pyruvate dehydrogenase and carnitine palmitoyl transferase) was assessed in diabetic rat myocardial tissue. Third, to explore metabolic adaptation at the genetic level, mRNA content of a variety of transport proteins and enzymes involved in cardiac glucose and FA utilization was measured. Special attention was paid to uncoupling protein 3 (UCP3), which is suggested to protect the mitochondrion against FA overload ${ }^{4}$.

In order to obtain more insight into the potential effect of enhanced supply of blood-borne FA and ketone bodies ("diabetic condition") to the cardiac muscle cells experiments were performed on isolated cultured neonatal cardiomyocytes incubated under normal and diabetic conditions. The impact of chronic exposure of cultured neonatal cardiomyocytes to FA and/or ketone bodies on the mRNA levels of a set of metabolic genes was subsequently monitored. Moreover, the effect of exposure of FA and/or ketone bodies on the promoter activity of carnitine palmitoyl transferase I (CPT1) was measured in transfected neonatal cardiomyocytes. In the latter experiments, distinction was made between acetoacetate (ACAC) and 3 - $\beta$-hydroxybutyrate $(3 \mathrm{HB})$, the most prominent ketone bodies in diabetic blood plasma.

\section{Material en methods}

\section{Determination of substrates in cardiac tissue and blood plasma}

To assess the content of FA and TG in diabetic rat heart, aliquots of muscle tissue ranging from 100 to $300 \mathrm{mg}$ wet weight were pulverized in an aluminum mortar with a stainless steel pestle, both cooled in liquid nitrogen.

The tissue powder was transferred to glass test tubes cooled in liquid nitrogen. The test tubes containing pulverized tissue were placed at $-21^{\circ} \mathrm{C}$ in a mixture of melting ice and $\mathrm{NaCl}$. The tissue powder was wetted with $2 \mathrm{ml}$ ice-cold methanol. The content of the test tubes was allowed to warm up to room temperature and weighed. According to the extraction procedure of Folch and co-workers ${ }^{5} 4 \mathrm{ml}$ chloroform was subsequently added. Butylated hydroxytoluene $(0.01 \%)$ was present in both methanol and chloroform to prevent auto-oxidation of lipids. Thereafter, heptadecanoic acid ( $8 \mathrm{nmol}$ ) was added to correct for losses of FA during the extraction and assay procedure 
(recovery standard). To assess the content of FA, TG and PL in blood plasma, $200 \mu$ il of blood plasma was extracted with a similar protocol.

The above mentioned lipid extracts were evaporated and subjected to one-dimensional thin-layer chromatography (TLC). The spots corresponding with FA, TG and PL were scraped from the plate and transmethylated according to Morrison and Smith . The identification and quantification of the fatty acyl moieties in the various lipid classes were achieved by capillary gas chromatography with the use of a standard solution of methyl esters of fatty acids ?

The glycogen content was determined in aliquots of freeze dried cardiac tissue, as previously described by Van der Vusse and colleagues ${ }^{8}$. Blood glucose was measured with the use of an automated glucose analyser (Euroflash $^{\text {MM }}$, Lifescan, Milpitas CA, USA).

\section{The content of COA and carnitine and their derivatives in cardiac tissue}

Cardiac tissue was homogenized in $3 \%$ perchloric acid $(v: v)$ and centrifuged for 2 minutes at $10,000 \times \mathrm{g}$. Long-chain acylcarnitines were determined in the resulting pellets after alkaline hydrolysis, and free in the perchloric acid supernatant by a radioenzymatic method originally described by Cederblad \& Lindstedt ${ }^{9}$ and modified by Brass and Hoppel ${ }^{10}$.

Homogenized cardiac tissue was extracted using a Bligh-Dyer technique, and long-chain acyl-CoA esters are harvested in the methanolic aqueous phase. Complex lipids and PL were removed in the chloroform-rich organic Bligh-Dyer second phase, and long-chain acyl-CoA compounds were further purified from the methanolic aqueous Bligh-Dyer first phase on C18 extraction columns after removal of the methanol. The acyl-CoA esters were then quantitated by RP-HPLC ${ }^{11}$.

Malonyl-CoA content in cardiac tissue was assayed radioenzymatically in neutralized perchloric acid filtrates by the method of McGarry and co-workers ${ }^{12}$, as described previously by Saha and colleagues ${ }^{13}$.

\section{Enzyme activity and UCP3 content}

Enzyme activities were measured in homogenates prepared according to the following standard technique. Aliquots of frozen tissue were thawed in SET buffer, containing (mM), sucrose (250), EDTA (2) and TRIS (10) (pH 7.4), and subsequently homogenized with the use of an Ultra Turrax. Thereafter, the circa $10 \%$ homogenate $(\mathrm{w} / \mathrm{v})$ was sonicated for $1 \mathrm{~min}(4 \times 15 \mathrm{~s}$, with $15 \mathrm{~s}$ 
rests) at $0^{\circ} \mathrm{C}$ with the use of an Ultrasonic disintegrator. The sonicated homogenates were centrifuged at $1200 \times \mathrm{g}$ and $4^{\circ} \mathrm{C}$ for 10 minutes, and the supernatants were stored at $-80^{\circ} \mathrm{C}$ for further analysis.

The activities of carnitine palmitoyl transferase I and II were assessed employing a radiochemical technique as previously described by Scholte and colleagues ${ }^{14}$.

To monitor pyruvate dehydrogenase (PDH) activity in cardiac samples; the following homogenization procedure was followed. Aliquots of frozen heart tissue were ground to a fine powder under liquid nitrogen. Each sample (circa $200 \mathrm{mg}$ tissue) was homogenized in an appropriate buffer (see below). The sample was then frozen in liquid nitrogen, allowed to thaw and re-homogenized. This freeze-thaw cycle was repeated once more. The sample was subsequently centrifuged in a cooled micro-centrifuge for 8 minutes. The supernatant was used in the PDH assay. To measure total $\mathrm{PDH}$ activity, tissue was homogenized in buffer containing $(\mathrm{mM}): \operatorname{HEPES}(75)$, dichloroacetate (5), $\mathrm{MgCl}_{2}$ (5), ADP (1), dithiotreitol (1), leupeptin (0.05) and Triton-X $(1 \%, v / v), \mathrm{pH} 7.0$. The buffer used to monitor the active form of PDH consisted of $(\mathrm{mM})$ : HEPES (25), $\mathrm{KH}_{2} \mathrm{PO}_{4}(25), \mathrm{KF}$ (25), dichloroacetate (1), $\operatorname{EDTA}(3), \operatorname{ADP}(1)$, dithiotreitol (1), leupeptin (0.05) and Triton-X $(1 \%, v / v)$, pH 7.O.

The activity of PDH was assayed in the presence of a pyruvate generating system, consisting of lactate, $\mathrm{NAD}^{*}$ and lactate dehydrogenase. To this end aliquots of the homogenates were incubated at $30^{\circ} \mathrm{C}$ in an incubation buffer containing in $\mathrm{mM}$ : HEPES (50), $\mathrm{MgCl}_{2}$ (1), EGTA (0.08), dithiotreitol (1), rotenone (0.004), $\operatorname{NAD}^{+}(1.67)$, thiamine pyrophosphate $(0.2)$, lactate (16.7) and lactate dehydrogenase $(2 \mathrm{U} / \mathrm{l}), \mathrm{pH} 7.2$. The production of NADH was continuously followed at $340 \mathrm{~nm}$ for 5 minutes. PDH activity was calculated from the linear portion of the curve, i.e., 0-30 s after the start of the reaction by addition of an aliquot of the tissue supernatant sample to the incubation buffer.

The cardiac tissue content of UCP 3 was measured according to Hesselink and co-workers ${ }^{15}$. In short, immunoblots of homogenized cardiac tissue were performed with the UCP3 antibody which was raised against amino acids 147-166 of human UCP3. The single protein band at $34 \mathrm{kDa}$, representing $U C P 3$, was quantified.

\section{MRNA content in cardiac tissue and neonatal cardiomyocytes}

Total RNA was isolated from cardiac tissue or neonatal cardiomyocytes with TRIzol reagent (GIBCO). RNA $(5 \mathrm{~g})$ was size-fractionated on a denaturizing gel ( $1 \%$ agarose, $6.6 \%$ formaldehyde, $1 \times$ MOPS), transferred to a nylon 
membrane (Hybond- $N$, Amersham, Slough, UK) by capillary transfer and fixed using standard techniques. Following prehybridization, the filters were probed with glucose transport protein 4 (GLUT4), hexokinase II (HKII), pyruvate dehydrogenase kinase 4 (PDK4), muscle type carnitine palmitoyl transferase (mCPT1), fatty acid translocase (FAT), fatty acid binding protein (FABP), acyl-COA synthetase (ACS), or long-chain acyl-CoA dehydrogenase (LCAD) according to Van der Lee and colleagues ${ }^{16}$. The CDNA probes were labeled with [ $\alpha_{-}^{-32}$ ]dCTP (3000 Ci/mmol; Amersham) by random-priming (Radprime, Life Technologies) to a specific activity of $>0.5 \times 109 \mathrm{cpm} \cdot \mathrm{g}$ DNA ${ }^{-1}$. To correct for possible differences in transfer and loading, the filters were also hybridized with a ${ }^{32}$ P-labelled ribosomal 185 probe. Following hybridization, filters were washed with the appropriate stringency to remove non-specific binding. The filters were exposed to phosphor imaging screens and subsequently scanned with a Phosphor-imager (Molecular Dynamics, Sunnyvale CA, USA), and quantified using ImageQuant software (Molecular Dynamics).

\section{Promoter-reporter mCPT-assay in neonatal cardiomyocytes}

For transient transfection, neonatal cardiomyocytes were seeded on 6-well plates at a density of $2.5 \times 10^{5}$ cells in $2 \mathrm{ml}$ medium per well. Cells were transfected $16 \mathrm{~h}$ before addition of experimental medium (DMEM/M199 4:1, $0.25 \mathrm{mM}$ L-carnitine, $0.25 \mathrm{mU} / \mathrm{ml}$ insulin and $0.15 \mathrm{mM}$ bovine serum albumin) using the transfection reagent FUGENE 6 (Roche, Indianapolis IN, USA). Cells were transfected with $0.5 \mu \mathrm{g}$ of promoter/reporter vector, i.e. $1.3 \mathrm{~kb}$ fragment of the human $\mathrm{mCPT}-1$ promoter generated by high fidelity PCR (Expand, Roche) of genomic DNA (corresponding to position 6120362543. Genbank Accession number U62317) and cloned into the pGL3 luciferase vector (mCPT1-luc). The CMV- $\beta$-galactosidase containing vector pON249 $(0.25 \mu \mathrm{g})$ was co-transfected to determine transfection efficiency. The total amount of plasmid DNA per well was always kept constant by adding empty $\mathrm{PSG} 5$ vector (Promega, Madison, WI, USA).

Cells were harvested 24 hours after addition of the experimental medium and immediately processed for the determination of reporter activity. Luciferase activity was determined using a commercial firefly luciferase assay according to the suppliers' instructions (Steady $\mathrm{Glo}^{\mathrm{TM}}$, Promega) in white 96-well plates (Nalge Nunc International, Maperville, IL, USA) and Fluors imager (Bio-Rad) for measuring luminescence. $\beta$-galactosidase activity was determined spectrophotometrically (Titertek Multiscan Plus MKIl, Thermo LabSystems, Helsinki, Finland) as described previously ${ }^{17}$. 
Statistical analysis

Analysis of experiments within one group was performed with a two-tailed student's $t$ test. Comparison between groups was performed with the one-way analysis of variance (ANOVA). In case the $F$ ratio obtained indicated that significant differences between groups were present, a two-tailed Student's $t$ test for unpaired data was carried out. For all analyses, the level of significance was set at 0.05 .

Figure 7.1 Schematic representation of cardiac energy converting pathways

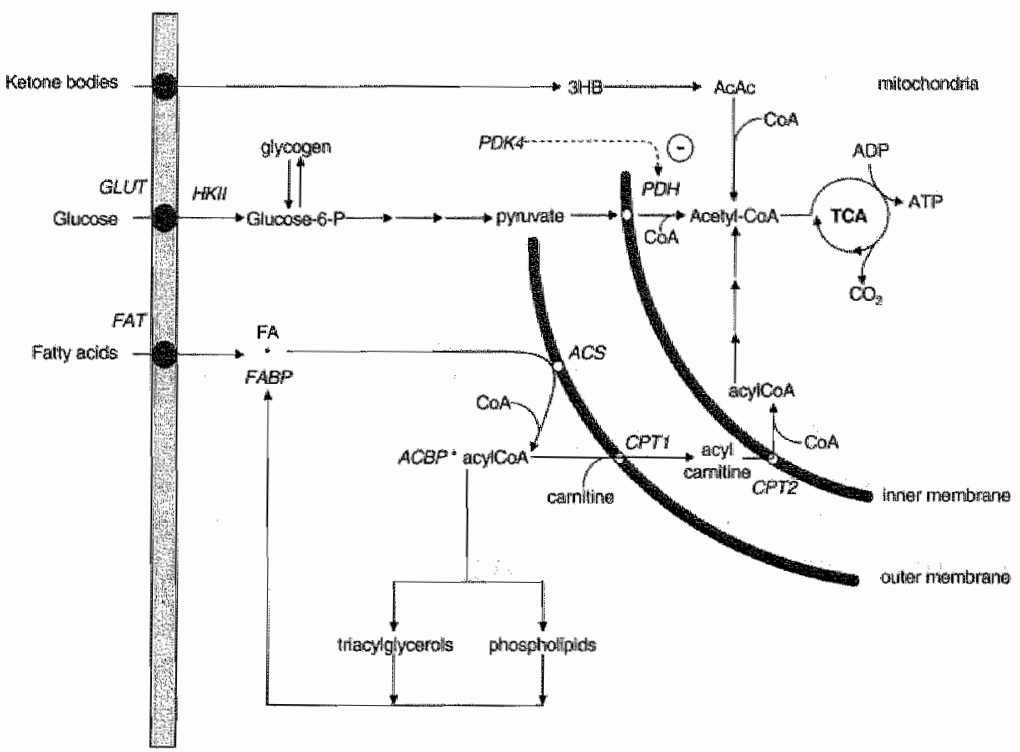

3HB, 3- $\beta$-Hydroxybutyrate; ACAC, acetoacetate; CoA, Coenzyme A; GLUT, glucose transport protein; HKII, hexolkinase II; PDH, pyruvate dehydrogenase; PDK4, pyruvate dehydrogenase kinase 4; FAT, fatty acid translocase; FABP, fatty acid-binding protein; $A C B P$, acyl-COA binding protein; ACS, acyl-COA synthetase; CPT1/2, carnitine paimitoyl transferase 1/2, TCA, tricarboxylic acid cyle; ADP, adenosine diphosphate; ATP, adenosine triphosphate.

\section{Results and discussion}

As expected and previously shown by others ${ }^{18,19}$, plasma glucose concentration dramatically increases in the streptozotocin-treated animals, due to the destruction of the $\beta$-cells of the pancreas and the subsequent lack of circulating insulin (table 7.1). Plasma long-chain FA significantly increased in the diabetic animals. This increase is most likely caused by a decline in the capacity to store FA in adipose tissue due to the lack of insulin. The latter 


\section{2 / Chapter 7}

hormone is, among others, able to inhibit hormone sensitive lipase, and hence, to enhance the sequestration of FA in adipocytes.

Table 7.1 Substrate and hormone concentration in blood plasma of streptozotocintreated rats and age-matched controls

\begin{tabular}{|c|c|c|}
\hline$\therefore$ & Control & Dilabetic \\
\hline \multicolumn{3}{|l|}{ Substrates } \\
\hline Glucose $(\mathrm{mM})$ & $9.1 \pm 1.0$ & $20.4 \pm 6.5^{*}$ \\
\hline Fatty acid $(\mu M)$ & $134 \pm 59$ & $265 \pm 88^{*}$ \\
\hline Triacylglycerols (mM) & $1.7 \pm 0.4$ & $9.1 \pm 1.9^{*}$ \\
\hline Phospholipids (mM) & $2.6 \pm 0.7$ & $5.0 \pm 1.1^{*}$ \\
\hline Acetoacetate $(\mu M)$ & 15 & $996 \$^{*}$ \\
\hline 3- $\beta$-hydroxybutyrate $(\mu M)$ & 16 & 22786 \\
\hline \multicolumn{3}{|l|}{ Hormones } \\
\hline Insulin (ng.ml ${ }^{x^{-1}}$ ) & $10.5 \pm 2.3$ & $0.6 \pm 0.1$ \\
\hline Glucagon $\left(\mathrm{pg} \cdot \mathrm{mil}^{-1}\right)$ & $62 \pm 10$ & $57 \pm 13 \#$ \\
\hline
\end{tabular}

$\$$ data from Charlton et al "; \# data from Nannipieri et al. "." indicating significant difference $(p<0.05) . n=8$ for both control and diabetic group

The increases in plasma triacylglycerol (TG) and phospholipids (PL) (table 7.1) point towards a severe disturbed lipoprotein metabolism in streptozotocintreated rats. Lack of lipoprotein lipase at the endothelial glycocalix, due to the virtual absence of insulin, and enhanced lipoprotein synthesis in liver as a consequence of increased supply of blood-borne FA to this organ, most likely contributes to the significant increase in circulating esterified lipids in streptozotocin-treated rats

The unchanged level of plasma glucagon and the decline in insulin strongly promotes the synthesis of ketone bodies in the liver cells ${ }^{20}$. This effect is strengthened by an increased supply of FA, being the substrate for the synthesis of acetoacetate and 3- $\beta$-hydroxybutyrate in the mitochondrial compartment of the hepatocyte ${ }^{20}$.

The alterations in circulating substrate concentrations are also reflected in changes in cardiac tissue substrate content. Glycogen content more than doubled in the diabetic heart (table 7.2) indicating a mismatch between glucose uptake and glucose degradation. Since glucose uptake is most likely impaired due to the lack of insulin, cardiac glucose degradation must be severely impaired in order to explain the accumulation of glycogen. In this respect the findings shown in table 7.4 are of interest. In the diabetic heart, 
the total, maximal activity of pyruvate dehydrogenase (PDH) is significantly depressed, most likely reflecting a down-regulation of the expression of this enzyme.

Moreover, the percentage of the enzyme in its active form dropped from $44 \%$ (control) to $4 \%$ (diabetic). The latter finding indicates that the activity of $\mathrm{PDH}$, catalysing the conversion of pyruvate into acetylCoA (figure 7.1) is also impaired at the post-translational level, most likely due to increased phosphorylation of the enzyme complex by pyruvate dehydrogenase kinase $^{21,22}$.

Table 7.2 Substrate content in cardiac tissue of normal and diabetic rats

\begin{tabular}{lll}
\cline { 2 - 3 } & Control & Diabetic \\
\hline Substrates & & \\
Glycogen $\left(\mu \mathrm{mol} \cdot \mathrm{g} \mathrm{dw}^{-1}\right)$ & $119 \pm 51$ & $278 \pm 55^{*}$ \\
Fatty acids $\left(\mathrm{nmol} \cdot \mathrm{g} \mathrm{dw^{-1 }}\right)$ & $338 \pm 83$ & $1631 \pm 315^{*}$ \\
Triacylglycerols $\left(\mu \mathrm{mol} \cdot \mathrm{g} \mathrm{d} w^{-1}\right)$ & $19.6 \pm 5.0$ & $36.4 \pm 5.3^{*}$ \\
Phospholipids $\left(\mu \mathrm{mol} \cdot \mathrm{g} \mathrm{d} \mathrm{w}^{-1}\right)$ & $152 \pm 14$ & $152 \pm 9$ \\
\hline
\end{tabular}

* significantly different from control; $n=8$ for both control and diabetic group

It is tempting to state that enhanced phosphorylation is caused by increased PDK activity, most likely due to enhanced expression of the latter enzyme, since cardiac mRNA levels of PDK4 showed a significant, more than 7-fold increase in the streptozotocin-treated heart (table 7.6). The decline in mRNA content of GLUT4 and HKII (table 7.6) also suggest that uptake and glycolytic conversion of glucose into pyruvate is hampered in the streptozotocintreated heart. It is intriguing to notice that although these alterations in key enzymes of glucose metabolism, favoring decreased uptake and glycolytic conversion of glucose, uptake of glucose still surpasses the amount of glucose consumed as indicated by the increase in the glycogen content.

As shown before in chapter 3 and by others ${ }^{23}$, cardiac FA content significantly increases in the diabetic heart. The same holds for the TG pool, containing glycerol-esterified fatty acyl moieties. Both alterations indicate a mismatch between uptake and oxidation of FA in the streptozotocin treated heart. There is no doubt that the increased supply of blood-borne FA will add to increased uptake of FA by the cardiac muscle cell. This notion is supported by findings presented in chapter 6 showing that the uptake rate of FA by isolated cardiomyocytes is significantly enhanced when the extracellular concentration of FA is increased. 


\section{$124 \mid$ Chapter 7}

In spite of the current paradigm that FA oxidation is augmented in the diabetic heart " uptake rate of FA must surpass utilization rate to explain accumulation of FA and TG. In chapter 6 this paradigm was challenged by showing that the elevated availability of ketone bodies such as acetoacetate, effectively inhibits cardiomyocyte FA oxidation without affecting cellular FA uptake rate, thereby creating a mismatch between uptake and utilization and providing a feasible explanation for lipid accumulation in the streptozotocin-treated rat heart.

Disturbed fatty acid utilization is also characterized by the changes in the tissue content of cofactors, such as $\mathrm{COA}$ and carnitine, required for mitochondrial uptake and oxidation of long-chain fatty acyl moieties (figure 7.1). In this respect it is of interest to note that both the total carnitine and the free carnitine pool are depressed in the diabetic heart (table 7.3$)^{24}$.

Table 7.3 Content of cofactors involved in energy metabolism of normal and diabetic rat heart

\begin{tabular}{|c|c|c|}
\hline \multirow{2}{*}{ 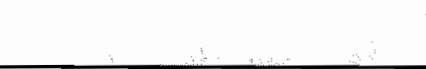 } & \\
\hline & Control & Diabetic \\
\hline \multicolumn{3}{|l|}{ Cofactor } \\
\hline Total carnitine (nmol.g ww ${ }^{-1}$ ) & $812 \pm 171$ & $385 \pm 191 *$ \\
\hline Free carnitine ( $\left.\mathrm{nmol}^{\mathrm{g}} \mathrm{w} \mathrm{w}^{*}\right)$ & $295 \pm 139$ & n.d.* \\
\hline Free CoA $\left(\mathrm{nmol}^{\circ} \mathrm{g} \mathrm{dw} \mathrm{w}^{-1}\right)$ & $414 \pm 69$ & $262 \pm 74^{*}$ \\
\hline Acetyl-CoA (nmol-g d $\left.w^{-1}\right)$ & $143 \pm 86$ & $151 \pm 79$ \\
\hline Malonyl-CoA $\left(n m o l \cdot g d w^{-1}\right)$ & $19 \pm 5$ & $14 \pm 5$ \\
\hline
\end{tabular}

n.d.: not detectable; "indicates significantly different from control $(P<0.05)$

Since carnitine is required for transport of FA across the mitochondrial inner membrane a decline in the pool size of this cofactor might not be in favour of enhanced FA oxidation by the diabetic heart. However, experiments performed with isolated cardiomyocytes derived from control and diabetic rats seem contraindicative to the importance or contribution of the total and free carnitine pool to the disturbed energy metabolism observed in diabetes. Cardiomyocytes isolated from diabetic rats which have a significant decreased total and free carnitine pool, show increased fatty acid oxidation in the absence of alternate substrates such as ketone bodies as compared to control (chapter 6). This observed increase in fatty acid oxidation in diabetic cardiomyocytes questions the importance and the precise role of the carnitine system in fuel selection and oxidation. It is of interest to note that 
the findings in isolated cardiomyocytes support the observations in intact, isolated hearts of diabetic rats. When these hearts were perfused with FA containing buffer, i.e. in the absence of competing substrates, FA oxidation was found to be higher than in control hearts ${ }^{1,2}$. However trials with human patients which received carnitine supplementation showed that FA oxidation as well as glucose disposal is increased ${ }^{25,26}$. This might indicate that there is a role for carnitine in the disturbed energy metabolizing pathway as seen during diabetes. Another observation concerning carnitine, was made by Aoshima and colleagues ${ }^{27}$ who showed that not only the carnitine pool size is altered, but also the distribution of long-chain acylcarnitine is distorted, with an increased level of long-chain acylcarnitine in the mitochondrial matrix. The authors concluded that this disturbance might be partially responsible to the impaired energy metabolism observed in diabetes, leading to the accumulation of FA and TG.

The decline in tissue of free coenzyme $A$ content in the diabetic rat heart (table 7.3) may also point to a disturbed FA handling. Unfortunately, no information is present about the intracellular distribution of the decreased $\mathrm{CoA}$ content. In case the intramitochondrial COA concentration is also decreased, this change may contribute to impaired FA oxidation in the mitochondrial matrix.

It should be emphasized that the concentration of malonyl-COA is not significantly changed in the streptozotocin-treated rat heart. Malonyl-CoA has been assigned a prominent role in controlling the oxidation rate of $F A$ in cardiac muscle cells ${ }^{28}$. A decline in malonyl-CoA is thought to lessen the inhibition of carnitine palmitoyl transferase l. However, due to the lack of change in tissue malonyl-CoA content, a significant role in governing cardiac FA oxidation under the present conditions does not seem feasible.

Table 7.4 Enzyme activity in cardiac tissue of normal and diabetic rats

\begin{tabular}{|c|c|c|}
\hline \multirow{2}{*}{ 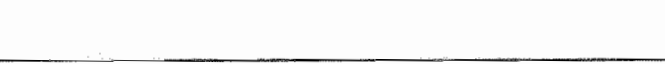 } & \\
\hline & Control & Dilabetic \\
\hline Carnitine palmitoyl transferase $1\left(\mathrm{mU} \cdot \mathrm{g} \mathrm{ww}{ }^{-1}\right)$ & $60.8 \pm 21.7$ & $42 \pm 21.9$ \\
\hline Carnitine palmitoyl transferase $2\left(\mathrm{mu} g \mathrm{~g} w \mathrm{w}^{-1}\right)$ & $165 \pm 97$ & $164 \pm 80$ \\
\hline Total PDH activity (mU.g ww $\left.w^{-1}\right)$ & $4.69 \pm 0.68$ & $2.84 \pm 1.26^{*}$ \\
\hline Active form $P D H\left(m U \cdot g w w^{-1}\right)$ & $2.17 \pm 0.78$ & $0.12 \pm 0.22$ \\
\hline Percentage (active/total) & 44.3 & $4.2^{*}$ \\
\hline $\operatorname{PDK} 4\left(\mathrm{AU} \cdot \mathrm{min}^{-1}\right)$ & $0.67 \pm 0.10$ & $1.71 \pm 0.099^{*}$ \\
\hline
\end{tabular}

PDH-pyruvate dehydrogenase; PDK4-pyruvate dehydrogenase kinase 4. AU-arbitrary units * indicates significantly different from control $(p<0.05)$; $§$ data from Wu and colleagues ${ }^{22}$. 
Table 7.4 shows that the activity of CPT1, although not significantly altered, shows a trend to decline. As CPT1 is involved in the transport of fatty acyl moieties across the mitochondrial membrane, it is likely that the decreased activity of CPT1, if any, is repressing the increased FA oxidation due increased substrate availability. In this respect, it should be noted that the activity of CPT2, an enzyme which is also involved in the transport of FA across the mitochondrial membrane, is not decreased.

Finally, cardiac FA oxidation may be inhibited by the elevated concentration of competing substrates such as ketone bodies. This notion is strongly supported by findings presented in chapter 6 .

One of the possible points of regulation by altered availability of substrates is the expression of metabolic genes, since previous studies have shown that for instance FA influences the expression of glucose and FA handling genes ${ }^{16}$. Data in table 7.6 clearly shows that the expression levels of two enzymes, MCPT1 and ACS are not altered in the diabetic heart compared to control. This finding corroborates with data on the enzymatic activity of CPT1 (table 7.4).

Taking into account that chronic exposure of isolated cardiomyocytes to FA (reference 16 and figure 7.2) significantly elevates the mRNA levels of FA handling genes; the present findings suggest a complex mechanism, underlying the regulation of gene expression in the diabetic heart. The fact that expression of $\mathrm{mCPT} 1$ and ACS is not altered despite the substantial accumulation of FA in the diabetic heart may point towards, among others, to i)- profound differences in adult and neonatal cardiomyocytes, ii)-alterations in the intrinsic mechanisms underlying gene expression in the diabetic state and/or iii)- the presence of other compounds mitigating the stimulatory effects of FA. Likely candidates are ketone bodies, known to be significantly increased under diabetic conditions.

To investigate the role of ketone bodies on gene expression and their effect on FA modulated gene expression, neonatal cardiomyocytes were incubated in the presence or absence of ketone bodies, and a number of genes in the fatty acid metabolizing pathway were measured (figure 7.2). It shows that as previously found ${ }^{16}$, FA is capable to induce the expression of genes encoding for FAT, FABP, ACS and LCAD in neonatal cardiomyocytes. $A C A C$ or $3 \mathrm{HB}$ or a combination of both did not have any effect on gene expression. When neonatal cardiomyocytes are incubated in the presence of $A C A C$ or $3 \mathrm{HB}$ combined with FA, the FA induced upregulation of genes encoding for the above mentioned FA handling proteins was not altered.

When transfected neonatal cardiomyocytes are incubated with a combination of FA and ACAC, there is no significant change as compared to 
up-regulation observed in incubations with $F A$ alone. However, incubations with $\mathrm{FA}$ in the presence of $3 \mathrm{HB}$ or a combination of ketone bodies showed a significant decline in promoter activity, which could explain the trend in decreased enzyme activity of CPT1 as observed in the intact diabetic heart; exposed to increased levels of circulating ketone bodies (table 7.4).

Figure 7.2 Effect of exposure to FA and ketone bodies of neonatal cardiomyocytes on mRNA levels
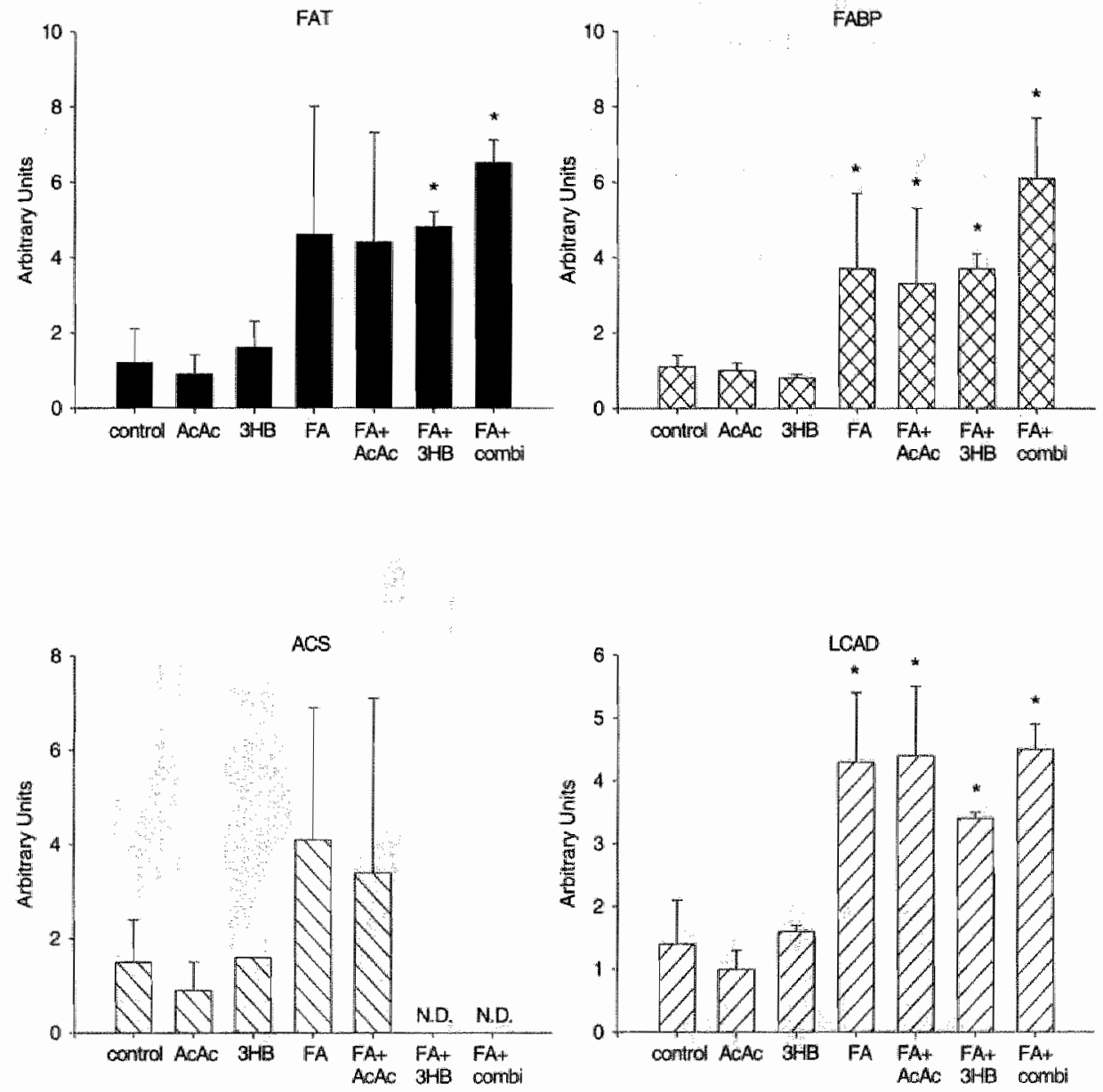

FAT (fatty acid translocase); FABP (fatty acid binding protein); ACS (acyll COA synthetase) and $\angle C A D$ (long-chain acylCOA dehydrogenase). ACAC (acetoacetate, $3 \mathrm{mM}$ ), 3HB (3-B-hydroxybutyrate, $3 \mathrm{mM}$ ), combi (2 $\mathrm{mM} \mathrm{AcAc}+4 \mathrm{mM}$ 3HB). " significantly different from control (glucose only) $(p<0.05) \mathrm{n}=3$ for all conditions. N.D. Not Determined 
The extent of inhibition is however insufficient to fully explain the total lack of increase of the MRNA of CPT1 in the diabetic heart, indicating that other factors and/or mechanisms, the nature of which are unknown at present, are playing a role in the regulation of gene expression in the diabetic heart. The same conclusion most likely holds for the other FA handling genes. As outlined by Young and colleagues in a recent review on this subject matter glucose may fulfil this inhibitory role via repression of PPAR activation ${ }^{29}$.

In contrast, the decline in the expression of glucose handling genes such as GLUT4 and HKII in the diabetic heart follows the pattern observed in studies on neonatal cardiomyocytes chronically exposed to increased levels of FA ${ }^{16}$. These findings suggest that the substantially elevated FA content in the diabetic heart negatively affects the expression rate of genes encoding for glucose handling proteins and enzymes.

Figure 7.3 Effect of exposure to FA and ketone bodies of cultured neonatal cardiomyocytes transfected with the mCPT1-luciferase promoter-reporter construct.

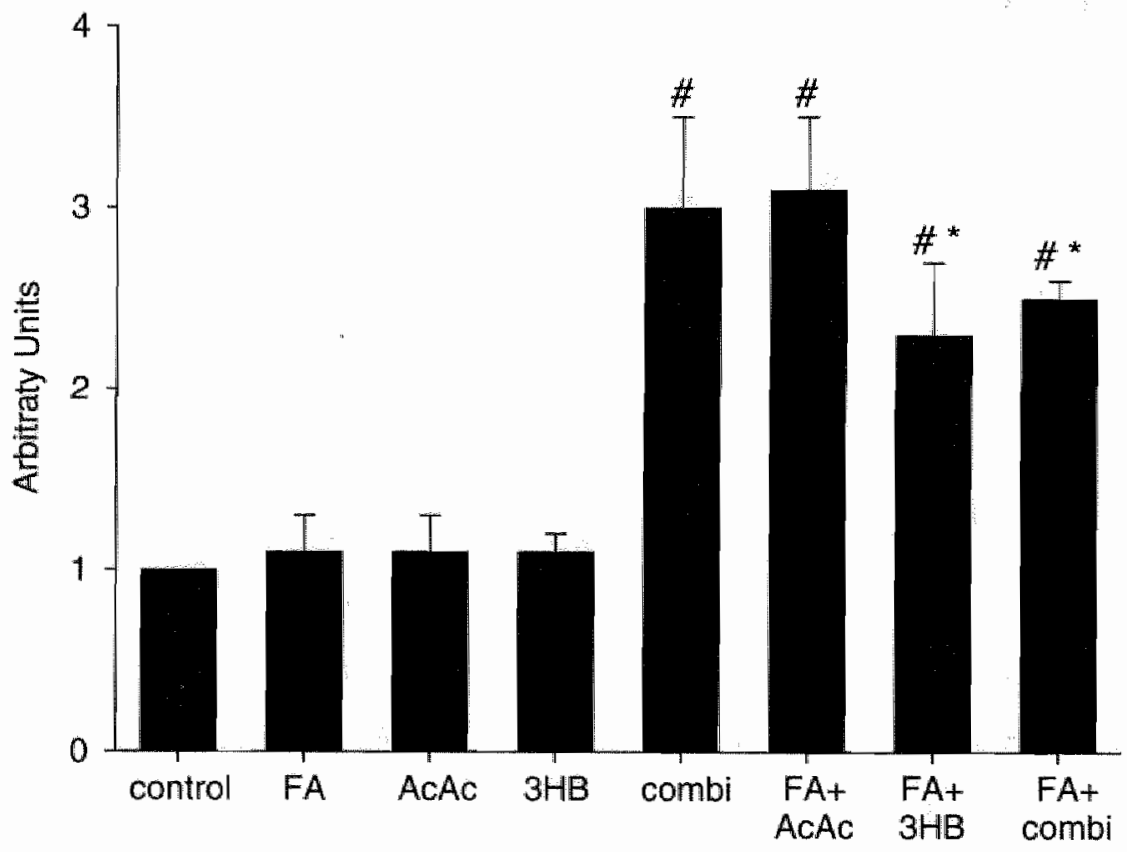

Contral (glucose only) was set at 1.0, other values relative to glucose only. See for details, legends to figure 7.2. \#significantly different from control $(p<0.05)$ * significantly different from FA only $(p<0.05)$ 
It is of interest to note that in the diabetic heart both MRNA levels of UCP3 (A. Gilde, unpublished results and others ${ }^{30,31}$ ) and protein levels (table 7.5) are significantly enhanced. The increase in protein levels (16-fold) substantially surpasses the increase in mRNA ( 4 -fold). This increase in tissue UCP3 is most likely due to the chronic exposure of the diabetic cardiac muscle cells to elevated intracellular FA levels. This notion is supported by observations of Gilde and co-workers (unpublished observation) showing that neonatal cardiomyocytes incubated in the presence of FA significantly up-regulate the expression of UCP3.

Table 7.5 UCP3 content in cardiac tissue of normal and diabetic rats

\begin{tabular}{lll} 
& Control & Diabetic \\
\hline UCP3 protein (AU) & $6.7 \pm 3.4$ & $107 \pm 25^{*}$ \\
\hline
\end{tabular}

$A \cup ;$ arbitrary units; " indicates significantlly different from control ( $p<0.05) ; n=6$

This strongly suggests a causal relationship between intracellular FA levels and the expression rate of UCP3. As pointed out earlier elevated intracellular FA levels may jeopardize intramitochondrial function if the intramitrochondrial content of FA surpasses safety limits ${ }^{4}$. It is hypothesized that the main function of UCP3 is to transport FA molecules from the mitochondrial matrix into the cytoplasm to prevent FA-induced damage, rather than to uncouple respiratory chain activity from oxygen consumption, rendering the diabetic cardiomyocyte less efficient from an energetic point of view.

Table 7.6 mRNA of transport proteins and enzymes in cardiac tissue of normal and diabetic rats

\begin{tabular}{lll} 
& \multicolumn{1}{c}{ Control } & \multicolumn{1}{c}{ Dlabetic } \\
\hline GLUT4 & $1.0 \pm 0.2$ & $0.4 \pm 0.05^{*}$ \\
Hexokinase I & $1.0 \pm 0.3$ & $0.4 \pm 1.0$ \\
PDK4 & $1.0 \pm 0.2$ & $7.1 \pm 3.1^{*}$ \\
& & \\
mCPT1 & $1.0 \pm 0.1$ & $1.2 \pm 0.2$ \\
ACS & $1.0 \pm 0.2$ & $1.1 \pm 0.4$ \\
\hline
\end{tabular}

Mean of control levels was set at 1.0; ", significantly different from control $(p<0.05), n=5$ 
In summary, it has become clear that the diabetic heart in situ adapts at various levels to the altered circumstances to which it is exposed. Although these adaptations allow the heart to cope with the changes it has to endure, these same adaptations eventually may lead to the development of cardiomyopathies. There is however a lack in understanding at which point or how these adaptations become maladaptations and thus contributes to the diseased state of the diabetic heart. More research concerning genetic and metabolic alterations is therefore necessary to unravel the mechanisms behind the development of diabetic cardiomyopathies.

\section{Acknowledgement}

The author is indebted to Patrick Schrauwen, Andries Gilde, Theo H. M. Roemen, Will Coumans, Peter Willems, Marc van Bilsen, and Ger J. van der Vusse for performing the chemical analysis and for stimulating discussions. 


\section{References}

1. Christe ME and Rodgers RL. Cardiac glucose and fatty acid oxidation in the streptozotocininduced diabetic spontaneously hypertensive rat. Hypertension 25: 235-241, 1995.

2. Saddik $M$ and Lopaschuk GD. Triacylglycerol turnover in isolated working hearts of acutely diabetic rats. Can J Physiol Pharmacol 72: 1110-1119, 1994.

3. van der Vusse GJ, Dubelaar ML, Coumans WA, Seymour AM, Clarke SB, Bonen A, DrakeHolland AJ and Noble MI. Metabolic alterations in the chronically dienervated dog heart. Cardiovasc Res 37: 160-170, 1998.

4. Schrauwen P, Saris WH and Hesselink MK. An alternative function for human uncoupling protein 3: protection of mitochondria against accumulation of nonesterified fatty acids inside the mitochondrial matrix. Faseb / 15: 2497-2502, 2001.

5. Folch J, Lees $M$ and Stanley HS. A simple method for the isolation and purification of total lipids from animal tissules. J. Biol. Chem. 226: 497-509, 1957.

6. Morrison WR and smith LM. Preparation of fatty acid methylesters and dimethylacetals from lipids with boron fluoride-methanol. I. Lipid Res. 5: 600-608, 1964 .

7. Hasselbaink DM, Roemen TH and van der Vusse GJ. Determination of long-chain fatty acids, triacylglycerols and phospholipids by capillary gas chromatography in cardiac tissue and blood plasma of normal and diabetic rats. Anal Chim Acta 465: 351-357, 2002.

8. Van der Vusse GJ, Coumans WA, Van der Veen FH, Drake AJ, Flameng W and Suy R. ATP, creatine phosphate and glycogen content in human myocardial biopsies: markers for the efficacy of cardioprotection. Vasc. Surg. 18: 127-134, 1984.

9. Cederblad $G$ and Lindstedt S. A method for the determination of carnitine in the picomole range. Clin Chim Acta 37: 235-243, 1972.

10. Brass EP and Hoppel CL. Carnitine metabolism in the fasting rat. / Biol Chem 253: 26882693, 1978.

11. Mangino MJ, Zografakis J, Murphy MK and Anderson CB. Improved and simplified tissue extraction method for quantitating long-chain acyl-coenzyme A thioesters with picomolar detection using high-performance liquid chromatography. J Chromatogr 577 : $157-162,1992$.

12. McGarry JD, Stark MJ and Foster DW. Hepatic malonyl-CoA levels of fed, fasted and diabetic rats as measured using a simple radioisotopic assay. J Biol Chem 253: 8291-8293, 1978.

13. Saha AK, Kurowski TG, Colca JR and Ruderman NB. Lipid abnormalities in tissues of the KKAy mouse: effects of pioglitazone on malonyl-COA and diacylglycerol. Am I Physiol 267 : E95-101, 1994.

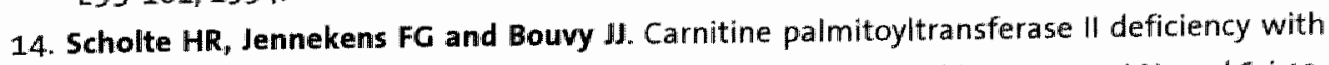
normal carnitine palmitoyltransferase I in skeletal muscle and leucocytes. I Neurol Sci 40 : 39-51, 1979. 
15. Hesselink MK, Keizer HA, Borghouts LB, Schalart C, Kornips CF, Slieker U, Sloop KW, Saris WH and Schrauwen P. Protein expression of UCP3 differs between human type 1, type 2.a, and type 2 b fibers. Faseb / 15: 1071-1073, 2001 .

16. vain der Lee KA, Vork MM, De Vries JE, Willemsen PH, Glatz JF, Reneman RS, Van der Vusse G) and Van Bilsen M. Long chain fatty acid-induced changes in gene expression in neonatal cardiac myocytes. J Lipid Res $41: 41-47,2000$.

17. Shubeita HE, Martinson EA, Van Bilsen $M$, Chien KR and Brown JH. Transcriptional activation of the cardiac myosin light chain 2 and atrial natriuretic factor genes by protein kinase C in neonatal rat ventricular myocytes. Proc Natl Acad Sci U S A 89: 1305$1309,1992$.

18. Stearns SB, Tepperman HM and Tepperman J. Studies on the utilization and mobilization of lipid in skeletal muscles from streptozotocin-diabetic and control rats. I Lipid Res 20: $654-662,1979$.

19. Wahren J, Hagenfeldt $L$ and Felig P. Splanchnic and leg exchange of glucose, amino acids, and free fatty acids during exercise in diabetes mellitus. I Clin Invest 55:1303-1314, 1975.

20. Laffel L. Ketone bodies: a review of physiology, pathophysiology and application of monitoring to diabetes. Diabetes Metab Res Rev 15: 412-426, 1999.

21. Randle PJ, sugden PH, Kerbey AL, Radcliffe PM and Hutson NJ. Regulation of pyruvate oxidation and the conservation of glucose. Blochem Soc 5ymp: 47-67, 1978.

22. Wu P, Inskeep K, Bowker-Kinley MM, Popov KM and Harris RA. Mechanism responsible for inactivation of skeletal muscle pyruvate dehydrogenase complex in starvation and diabetes. Diabetes 48: 1593-1599, 1999.

23. Heyliger CE, Scarim AL, Eymer VP, Skau KA and Powell DM. Characteristics of the myocardial PM-FABP: effect of diabetes mellitus. Mol Cell Biochem 176: 281-286, 1997.

24. Akisu $\mathbf{M}$, Kultursay $\mathbf{N}_{\text {, }}$ Coker $\mathbf{I}$ and Huseyinov A. Myocardial and hepatic free carnitime concentrations in pups of diabetic female rats. Ann Nutr Metab 46:45-48, 2002.

25. Mingrone G, Greco AV, Capristo E, Benedetti G, Glancaterini A, De Gaetano A and Gasbarrini G. L-Carnitine improves glucose disposal in type 2 diabetic patients. I Am Coll Nutr 18: 77-82, 1999.

26. Muller DM, Seim $H_{*}$ Kiess $W$, Loster $H$ and Richter T. Effects of oral L-carnitine supplementation on in vivo long-chain fatty acid oxidation in healthy adults. Metabolism 51: 1389-1391, 2002.

27. Aoshima S, Fujisawa S and Kobayashil A. Changes in the subcellular distribution of free carnitine and its acyl derivatives in diabetic rat hearts following treatment with Lcarnitine. Jpn Heart / 34: 763-772, 1993.

28. Lopaschuk GD and Barr RL. Measurements of fatty acid and carbohydrate metabolism in the isolated working rat heart. Mol Cell Biochem 172: 137-147, 1997.

29. Young ME, McNulty P and Taegtmeyer H. Adaptation and maladaptation of the heart in diabetes: Part Il: potential mechanisms. Circulation 105: 1861-1870, 2002. 


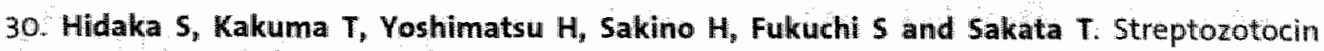
treatment upregulates uncoupling protein 3 expression in the rat heart. Diabetes $48: 430$ $435,1999$.

31. Young ME, Patil S, Ying J, Depre C, Ahuja HS, Shipley GL, Stepkowski SM, Davies PI and Taegtmeyer $H$. Uncoupling protein 3 transcription is regulated by peroxisome proliferator-activated receptor (alpha) in the adult rodent heart. Faseb J 15: 833-845. 2001.

32. Charlton JA, Thompson $\mathrm{CJ}$ and Baylis PH. Possible mechanisms responsible for the rise in plasma vasopressin associated with diabetic ketoacidosis in the rat. I Endocrinol 116:343$348,1988$.

33. Nannipieri $M$, Lanfranchi $A$, Santerini $D$, Catalano $C$, Van de Werve $G$ and Ferrannini $E$. Influence of long-term diabetes on renal glycogen metabolism in the rat. Nephron $87: 50$ 57, 2001. 



\section{Chapter 8}

General Discussion 


\section{Introduction}

For the production of energy, the heart is able to use a wide variety of substrates, including glucose, fatty acids and ketone bodies. Under certain pathophysiological conditions, like diabetes mellitus (DM), utilization of these substrates is altered. The disturbed balance between the uptake and utilization of these substrates and the altered preference for substrates, may eventually contribute to the development of diabetic cardiomyopathy ${ }^{1-4}$.

Cardiac energy metabolism has been the focus of research for a considerable time. During the early and mid nineteen's, experiments were performed on isolated hearts, on basis of which it was concluded that longchain fatty acid (FA) oxidation is increased in the diabetic state ${ }^{5-7}$. Turpeinen and colleagues, however, showed that the increased FA oxidation observed in isolated hearts were in contrast with observations in human diabetic patients ${ }^{8}$. They observed that cardiac FA oxidation of the commonly used FA tracer ${ }^{123} \mathrm{I}$-heptadecanoic acid was not different between diabetic patients, both insulin dependent DM (IDDM; type-1) and non-insulin dependent DM (NIDDM; type-2), and healthy controls. The same study by Turpeinen and colleagues showed a significant decrease in cardiac ${ }^{123}$ I-heptadecanoic acid oxidation in subjects with impaired glucose tolerance, which even stresses the differences in findings between isolated hearts from experimental animals and hearts in situ of human diabetic patients. The collected observations suggest that alterations of FA oxidation by the diabetic heart depend on the severity of the underlying disease, and furthermore that FA oxidation is governed by factors present in the in situ situation, but absent under experimental conditions.

The studies described in this thesis are aimed to explore major alterations in cardiac FA handling under diabetic conditions, with special reference to enhanced circulating levels of FA and ketone bodies and the consequences thereof on protein acylation. Moreover, a second goal of this thesis is to explore the discrepancy between observation in isolated hearts and results obtained from patients. Therefore, the role of the altered substrate availability, as seen in diabetes, on FA uptake and utilization, along with possible implications for the tissue content of cofactors and enzymes, involved in FA handling was investigated. Furthermore, the studies described in this thesis will try to add to the limited knowledge concerning the impact of the increased FA availability on the expression of metabolic genes under diabetic conditions and the regulatory role, if any, of ketone bodies therein. 


\section{Alterations in substrate availability under diabetic conditions}

Notwithstanding the discussion about the underlying causes that are ultimately responsible for the development of diabetic cardiomyopathies, it is agreed upon that the levels of FA and glucose during diabetes mellitus are increased in plasma as compared to substrate levels in healthy subjects. There is, however, still a great deal of debate about the consequences of the substrate alterations in plasma on energy metabolism and functioning of the cardiomyocyte.

The increases in plasma of FA and glucose during diabetes could be responsible for alterations in their uptake and utilization by sheer mass effects alone. The uptake and thus eventually the utilization of glucose is severely hampered by the lack of insulin or the lack of action of insulin, which is marking for diabetes, type-1 and type-2, respectively. Although the transport of glucose is limited due to the inability of GLUT4 to translocate to the plasmamembrane ${ }^{9}$ and thus to facilitate glucose uptake, glucose is still able to enter the cardiomyocyte via other glucose transporters such as, for instance, GLUT1 ${ }^{\circ}$. Despite the decline in the overall availability of transport proteins and, hence, transport of glucose across the plasmalemma, the uptake of glucose still surpasses the utilization, as the glycogen content in the diabetic cardiomyocte is increased (chapter 7). Evidence is accumulating that the flux through the glycolytic pathway and subsequent oxidation of pyruvate in the mitochondrial matrix is severely depressed in the diabetic heart (chapter 7, Kuo and colleagues ${ }^{10}$ ). Besides down regulation of key enzymes in the glycolytic pathway and of pyruvate dehydrogenase, posttranslational modification of the latter enzyme by enhanced activity of pyruvate dehydrogenase kinase is a likely cause of the severe decline in cardiac glucose degradation. Enhanced supply of blood-borne glucose and accumulation of glucose-derivatives in the cardiac cells may lead to glucotoxicity ${ }^{11}$.

As indicated above, the general paradigm states that FA oxidation in the diabetic heart is increased as compared to control, although this is in contrast with observations made in human subjects. The study described in chapter 6 showed intriguing observations explaining the contradictions observed between FA oxidation in isolated hearts versus cardiac FA oxidation in patients. This study made clear that the availability of an alternate substrate, namely acetoacetate (ACAC), one of the ketone bodies, was capable to suppress FA oxidation in cardiomyocytes derived from both healthy and diabetic rat hearts. In the absence of ACAC, the diabetic 
cardiomyocyte showed an increased FA oxidation when compared to control, which fits in the current paradigm concerning energy metabolism in the diabetic heart. It is worthy to mention that the concentration of AcAc needed for half maximum inhibition is between the $0.3-0.5 \mathrm{mM}$. This is a concentration which is reached far upfront the physiological signs of diabetic ketoacidosis and which can furthermore be reached under numerous other physiological or pathophysiological conditions, such as, fasting, pregnancy, alcoholic ketoacidosis and salicylate poisoning ${ }^{12}$.

\section{Lipid accumulation in the diabetic heart and lipotoxicity}

Lipotoxicity describes the negative effects of an excess of lipids which are detrimental for proper functioning of the organism or cell. Lipotoxicity is not only considered as an acute effect, by for instance causing apoptosis ${ }^{13}$, but also as an important process in the gradual decline of functioning occuring in diabetic cardiomyopathy.

The prolonged availability of a surplus of lipids in plasma as seen during diabetes leads to an increase in cardiac content of FA and TG. The increased intracellular FA level might be the primary cause of the altered fatty acyl composition of the plasma-membrane of the cardiomyocyte. The fatty acyl composition of the membrane is responsible for the properties of the phospholipid bilayer such as curvature and charge. In turn, membrane curvature can modulate the activity of membrane bound proteins ${ }^{14}$. The altered membrane properties can therefore be seen as primary lipotoxicity, while impaired functioning of membrane bound proteins can be considered as secondary lipotoxicity. Furthermore, the increase of intracellular FA is associated with several direct toxic effects which act on myofibrillar function, apoptosis and generation of reactive oxygen species ${ }^{15-18}$. The alterations in lipid metabolism could lead to the activation of signalling pathways related to myocyte dysfunction. Each of these points in interaction might contribute to occurrence of lipotoxicity and, hence, ultimately the development of diabetic cardiomyopathy.

An example of a recent discovery which may contribute to secondary lipotoxicity is an observation by Chao and co-workers who showed that the interaction of acyl-COA binding protein (ACBP) is also influenced by membrane charge and curvature ${ }^{19}$. The functioning of ACBP might be hampered by the alterations in the interaction of the protein with the plasma-membrane. Considering that ACBP is associated with the targeting of acyl-CoA to the various processes in which this fatty acyl derivative is 
used, it is likely that the disturbed interaction contributes to the lipotoxic effects observed in diabetes.

As earlier stated, it is clear that the balance between FA uptake and FA utilization is changed during diabetes mellitus, as can be appreciated from the enlarged TG pool observed in the diabetic heart ${ }^{20}$. Besides the increased TG pool, the surplus of FA has other effects, such as, an increased cardiac pool size of unesterified FA (chapter 3 ), an increase in the diacylglycerol (DG) content ${ }^{21}$, accumulation of acyl-CoA and an increase of acyl-carnitines ${ }^{22,23}$. Each of these disturbances could contribute to the lipotoxicity observed with increased FA plasma levels since toxic effects of acyl-CoA and acyl-carnitines have been described ${ }^{24}$.

\section{Fatty acids and signal transduction}

In addition to the role of FA in lipotoxicity, FA can also play a modulatory role by altering gene expression and influencing signalling transduction pathways. It is likely that FA are capable to alter signal transduction pathways in a different fashion than via influencing gene expression, namely
via protein acylation. It is known that protein acylation is a versatile modification playing a role in, for instance, protein-protein interactions, conformational changes, protein localization and protein activity ${ }^{25-29}$.

There are two forms of protein acylation, namely myristoylation and S-acylation (palmitoylation) ${ }^{30}$. Myristoylation is a co-translational modification of which the enzymology is well known ${ }^{31-33}$. S-acylation is a post-translational modification and the enzymatic process underlying this modification is less clear. Among the proteins which become covalently modified by FA, many of them are involved in signalling cascades, such as $G$ proteins and G-protein coupled receptors ${ }^{34-36}$. Since it has been shown that during diabetes signalling cascades are hampered, it is likely that altered protein acylation plays a significant role in this phenomenon.

There are two observations that might support the notion that there is a role of protein acylation in diabetes. First, King and colleagues showed that the activity of $\mathrm{N}$-myristoyl transferase, the enzyme responsible for the myristoylation of proteins, is lower in the liver of the obese Zucker rat than in control ${ }^{37}$.These authors suggested that inside the cell $\mathrm{N}$-myristoyl transferase exists in 2 populations, with the active form residing in the membrane. This may imply that translocation of $\mathrm{N}$-myristoyl transferase from the cytosol to the membrane is under direct influence of insulin and, thus, that the lack of insulin hampers this translocation. It is however 
doubtful that myristoylation is also impaired in the diabetic heart since the total amount of cardiac myristoylated proteins did not change under diabetic conditions (chapter 3). Second, the observation made in chapter 5 , which showed that the amount of proteins which become S-acylated in diabetic rat myocardium is significantly enhanced as compared to control underlines the notion that increased FA availlability may affect signalling pathways. This chapter also shows that the enhanced availability of ketone bodies may play a role in increased palmitoylation of proteins under diabetic conditions. It is if interest to note that although all fatty acyl moieties, including myristic acid, are increased during diabetes, the pool size of myristoylated proteins does not increase.

Previous studies have shown that chronic exposure of cardiomyocytes to FA is able to modulate, via PPAR, cardiac gene expression of a panel of cardiac enzymes/proteins involved in carbohydrate and fatty acid handling ${ }^{38-41}$. The elevation of plasma FA levels in diabetes is thought to result in activation of PPAR $\alpha$ and this, in turn, might induce the expression of PPAR $\alpha$ regulated genes, such as, UCP3, MCAD, LCAD, mCPT1, MCD and FAT ${ }^{41-46}$.

However, the findings of mRNA expression in experiments with isolated neonatal cardiac myocytes derived from neonatal rats and of adult diabetic cardiac tissue are, partly, in contradiction with each other. Studies with neonatal cardiomyocytes show that chronic exposure to FA substantially induces mRNA expression of metabolic genes, e.g. FAT, FABP, ACS, LCAD and $m C P T 1{ }^{42}$. However, in diabetic cardiac tissue the mRNA content of mCPT and ACS was not altered despite the chronic exposure of the heart to FA during diabetes. Although the underlying mechanism is not entirely clear, this phenomenon can be partially explained by the availability of alternative substrates which are capable to down-regulate gene expression to a certain extent. Chapter 7 showed that when neonatal cardiomyocytes are chronically exposed to FA in the presence of 3 - $\beta$-hydroxybutyrate (3HB), the expression of $\mathrm{MCPT} 1$ is decreased when compared to incubations in the absence of $3 \mathrm{HB}$. The extent of inhibition is, however, insufficient to fully explain the total lack of increase of the MRNA of MCPT1 in the diabetic heart, indicating that other factors and/or mechanisms, the nature of which are unknown at present, are playing a role in the regulation of gene expression in the diabetic heart. In this respect, it is worthy to note that Young and colleagues recently hypothesized that glucose or glucose-derivatives are able to prevent the up-regulation of FA handling genes 4 .

It is intriguing to observe that there is a striking difference between the effects of the two most common ketone bodies, ACAC and $3 \mathrm{HB}$. ACAC is able 
to inhibit FA oxidation in isolated adult cardiomyocytes at physiological levels $(0.3-0.5 \mathrm{mM})$ while $3 \mathrm{HB}$ does not influence $\mathrm{FA}$ oxidation at all. Conversely, $3 \mathrm{HB}$ is capable to down-regulate mCPT1 to a certain extent, while ACAC does not seem to possess this property. Considering the resemblance between $\mathrm{ACAC}$ and $3 \mathrm{HB}$ and the possibility of conversion of $A C A c$ to $3 \mathrm{HB}$ and vice versa, these observations might indicate the existence of a complex and subtle mechanism capable of influencing metabolism at both the level of substrate utilization and gene expression.

\section{Intervention and treatment}

It should be taken into account that the process underlying diabetic cardiomyopathy is multifactorial and that the development takes place gradually in time. Therefore, treatment of this major cause of death of the diabetic patient must be based on this notion.

One should keep in mind that the preferred point of intervention should be as early as possible in the chain of events, to minimize the side-effects of the applied therapy. Although significant differences between type-1 and type-2 diabetes exist, they have in common that plasma glucose and FA levels are disturbed. Therefore, the preferred initial pathway concerning treatment is identical between these two different forms of diabetes. In both cases one should strive to lower both plasma glucose and FA levels in order to normalize substrate availability to control values.

Considering the paradigm stating that FA oxidation is increased during diabetes and, hence, that the overshoot of FA oxidation is responsible for the detrimental effects observed in diabetes, newly developed anti-diabetica are aimed at lowering FA oxidation in the diabetic heart. However, the results from chapter 6 and observations in diabetic patients strongly suggest that cardiac FA oxidation is not increased and thus, that lowering FA oxidation might further enhance the lipotoxicity as observed in diabetic patients. In this light, one should consider to stimulate FA oxidation or the total oxidation capacity in general, to prevent the development of diabetic cardiomyopathy due to lipotoxicity, rather than to block FA oxidation in the diabetic heart.

In patients with type-1 diabetes normalization can be partially achieved via insulin treatment ${ }^{47}$. Although patients with type-2 diabetes show a decline in response to insulin, it might be possible to partially restore the insulin sensitivity in these patients via medication, thereby also achieving (partial) normalization of plasma glucose and FA. 
Recently, it has been advocated that the cellular uptake of FA might be a suitable target for pharmaceutical interventions. Since FA uptake is at least partially protein mediated, manipulation of the proteins involved in FA uptake might be a potential therapeutic target. A known inhibitor of fatty acid translocase (FAT), a protein associated with bulk transport of FA, is sulpho-N-succimidyl-oleate (5SO). Limiting uptake via the use of this kind of inhibitors might, however, have some major drawbacks which should be taken into account. As FAT is considered a multifunctional protein, homologous to $\mathrm{CD} 36$ which is present in macrophages and erythrocytes, one should be aware that inhibiting FAT with SSO would affect all these cell types, and thus hamper their proper function as well. Furthermore, if FA uptake is diminished by blocking FAT/CD36, blood plasma FA levels most likely increase which may enhance the risk of lipotoxicity in the vascular wall and in organs such as the liver.

In order to lower the plasma concentration of glucose and lipids, one may intervene in the uptake and utilization of other substrates such as ketone bodies. The intervention in the uptake of ketone bodies is a new lead which comes forth from the observations made in chapter 6 , which indicated that fatty acid oxidation in diabetic cardiomyocytes under "diabetic" conditions ( $160 \mu \mathrm{M}$ paimitate, $3 \mathrm{mM} \mathrm{ACAc}$ ) is comparable to FA oxidation in control cardiomyocytes under "normal" conditions $(80 \mu \mathrm{M}$ palmitate, $0 \mathrm{mM}$ ACAC). Monocarboxylate transporters (MCT) are involved in the transport of short-chain aliphatic monocarboxylates, such as ketone bodies ${ }^{48}$. The existence of a high affinity monocarboxylate transporter, MCT2, present in cardiomyocytes, opens up the possibility for attenuating ketone body uptake. By limiting cardiac ketone body uptake, the cardiomyocytes would be forced to switch to other substrates to sustain the constant need for ATP generation, thereby possibly increasing FA and glucose oxidation, and thus preventing intracellular accumulation of FA, TG and glycogen.

If the above mentioned measures are not sufficient to prevent lipotoxicity or the development of diabetic cardiomyopathy one could consider intervening lower in the chain leading to these events.

For instance, total and free carnitine contents in the diabetic myocardium are significantly decreased. In essence, L-carnitine plays a crucial role in lipid and carbohydrate metabolism and is required for proper functioning of heart and skeletal muscle. The carnitine system is of importance to regulate the localized, limited pools of CoA derivatives ${ }^{49,50}$. Short-chain acylcarnitines are generated by the action of carnitine acetylCoA transferase ${ }^{5 x}$. This reaction liberates free CoA which is an important 
substrate for different steps in mitochondrial energy metabolism such as pyruvate dehydrogenase and fatty acid oxidation.

The carnitine content in diabetic cardiac tissue, which is lower than in control hearts, is most likely responsible for the decreased availability of free COA and the disruption of the ratio between free COA and acyl-COA. It is hypothesized that increasing the availability of free carnitine should lead to rise in free $\mathrm{COA}$, by restoring the ratio between free $\mathrm{COA}$ and $\mathrm{acyl}-\mathrm{COA}$, and potentially counteracting deleterious lipotoxic effects of acyl-COA ${ }^{51}$. In addition, a decline in carnitine content might be associated with a limited ability to oxidize FA. However, chapter 6 shows that myocytes derived from diabetic hearts with decreased carnitine content (see chapter 7) have a significantly higher FA oxidation rate than control cardiomyocytes when incubated in the absence of competing substrates. This observation is contra-intuitive and underlines the complexity of how FA oxidation is regulated in the cardiac muscle cells. The collected data indicate that besides carnitine other factors are playing an important role in governing the flux rate of FA in diabetic hearts. Notwithstanding these considerations, attempts have been made to mitigate lipotoxicity under diabetic conditions through enhancing the availability of carnitine in the heart.

Although L-carnitine is mainly synthesized by the liver, from where it is transported to heart and skeletal muscle, it can also be taken up from food. Dietary L-carnitine supplementation could therefore be a means by which the free carnitine pool can be restored. Although the beneficial effects of carnitine supplementation are recognized ${ }^{52}$, general acceptance of this treatment has been hampered by the lack of knowledge of both the metabolic disturbances caused by carnitine deficiency and of the underlying cellular mechanism. However, Coker and colleagues strongly recommended, on the basis of a clinical study concerning carnitine metabolism in diabetes mellitus, carnitine supplementation to diabetic patients ${ }^{53}$.

At the same level of entry, there is the CPT system that can be used as therapeutic target. The $\beta$-oxidation of activated fatty acids occurs within the mitochondrial matrix and is catalyzed by the sequential action of four enzymes (acyl-CoA dehydrogenase, enoyl-CoA hydratase, 3-hydroxyacyl-CoA dehydrogenase and 3-ketoacyl thiolase). The carnitine dependent transport precedes the $\beta$-oxidative chain shortening of these activated fatty acids. This transport system consists of three proteins namely, carnitine palmitoyl transferase I (CPT 1), carnitine acyl-transferase (CAT) and carnitine palmitoyl transferase II (CPT 2), each with a different localization inside the mitochondria. The first step is the conversion of fatty acyl-CoA to acylcarnitine, catalyzed by CPT1 which is localized in the mitochondrial 
outer-membrane. In general, CPT1 mediated transport is recognized as the rate-limiting step in the overall transport of acyl-carnitines across the mitochondrial membrane, and thus crucial in regulating myocardial fatty acid oxidation.

Two isoforms of CPT1 exist, the l(iver) and $m$ (uscle) isoforms. Both isoforms are present in the heart, although the m-type dominates. MalonylCOA is associated with allosteric inhibition of CPT1, resulting in reduced fatty acid oxidation ${ }^{54}$. Situations, in which the intracellular malonyl-CoA concentration is increased, are associated with decreased FA oxidation ${ }^{55-57}$. The two isoforms have different kinetic and regulatory properties and differ in tissue distribution ${ }^{54,58}$. The l-type displays a higher affinity for carnitine and lower affinity for malonyl-CoA in contrast to the m-type. By finding means to alter the ratio between the I-type and the m-type of CPT1, differential overall sensitivity to malonyl-COA could be achieved. This would be a mean by which FA oxidation in the cardiomyocyte can be tuned to regain the balance between $F A$ oxidation and glucose utilization.

In the recent past, the use of an inhibitor of the carnitine palmitoyl transferase system has been advocated as therapeutic measure under diabetic conditions. Treatment with etomoxir, a well known irreversible CPT1 inhibitor, is based on the paradigm that increased FA oxidation is detrimental to the heart and aggravates the unfavourable conditions created by diabetes mellitus. The decline in FA oxidation should force the muscles to increase glucose oxidation and, hence, to mitigate the unfavourable effects of disturbed carbohydrate homeostasis on the body. In studies with isolated cardiomyocytes, etomoxir was able to inhibit oxidation of palmitate virtually completely in combination with a decreased palmitate uptake of approximately 50\% $(\mathrm{H}$. Niessen and co-workers, unpublished results; Luiken and colleagues ${ }^{59}$ ). In clinical trials concerning patients with diabetes or chronic congestive heart failure, which lasted three months or less, showed that inhibition of CPT1 led to an increase of the SERCA2 protein and the $\alpha$-myosin heavy chain. Furthermore, it was shown that treatment with etomoxir gave an improvement of clinical end points, such as, improved clinical status and central haemodynamics ${ }^{60}$. Although inhibition of CPT1 seems beneficial, the in vivo use of etomoxir showed to be detrimental in a variety of other experimental settings. Administration of etomoxir to rats led to marked liver hypertrophy and to a lesser extent to hypertrophy of the heart ${ }^{61-63}$. Furthermore, it was shown that prolonged inhibition of CPT1 with etomoxir caused intramyocellular lipid accumulation and insulin resistance in rats ${ }^{64}$. Finally, in a recent study Cabrero and colleagues showed that etomoxir led to increased cellular oxidative stress 
and NF-KB activity in hearts of the etomoxir treated mice ${ }^{65}$. The evidence mentioned above indicates that CPT1 inhibition might not be an appropriate target for the treatment of diabetes due to the observed hepatic and myocardial toxicities observed in animals.

To intervene at an even lower level in the chain, at the point of signal transduction pathways, would not be without risk since it is difficult to predict the outcome due to cross-talk between the different signalling pathways. Nevertheless, it would still be of interest to explore the possibilities for attenuating signal transduction pathways via, for instance, modulation of protein acylation. However, until recently no protein could be purified which could be held responsible for S-acylation. The recent discovery of a polytopic membrane protein, Akr1p, containing a cysteine rich domain, as a palmitoyl transferase opens a variety of new and intriguing possibilities ${ }^{66}$. Although the protein was discovered in yeast, it is the first time that a protein was purified to near homogeneity. Earlier attempts to identify a protein with palmitoyl transferase activity were not successful and led only to partially purified membrane fractions with enzymatic activity ${ }^{67,68}$. The Akr1p protein can now be used as a tool to identify possible eukaryotic candidates, sharing homology, with the same characteristics as Akr1p. This would be the first step in unravelling the enzymatic pathways underlying protein palmitoylation, and could lead to new areas of therapeutic interventions.

Intervening distal in the chain of events, plasma lipid and glucose lowering can also be achieved via treatment with PPAR $\gamma$ agonists. Originally, it has been suggested that this can be established via altered conformational stability leading to distinctive gene expression profiles, reduced adipogenic cellular effects, and potentially improved in vivo biological responses. Therefore, PPAR $\gamma$ modulators may lead to preferred therapies for diabetes and obesity ${ }^{69,70}$. However Larsen and co-workers questioned the long term use of PPARy agonists, due to a major drawback of the chronic application of thiazoledinediones, a group of PPAR $\gamma$ agonists, namely the substantial increase in body fat mass ${ }^{71}$. Considering the fact that excess body fat plays a role in the development of diabetes, long term treatment of diabetes with this medication may be detrimental to the diabetic patient. Alternatively, the recent use of PPAR $\beta / \delta$ agonists in rhesus monkeys showed a significant decrease in triacylglycerols, combined with an increase in HDL cholesterol, thereby increasing the reverse cholesterol transport, which might be beneficial in altering the atherogenic particle composition ${ }^{72,73}$. 
The results suggest that PPAR $\beta / \delta$ agonists may be a more effective drug to treat diabetic patients than PPARY agonists.

\section{Future perspectives}

To fully comprehend energy metabolism in the diabetic heart, it is necessary to unravel the contribution of the different substrates in a variety of circumstances to energy homeostasis. The results in chapter 6 , indicating that ketone bodies are potent inhibitors of FA oxidation, even at subclinical concentrations, are of great interest. In this respect, it is of the utmost importance to unravel the causes and the consequences of relatively small increases in the level of circulating ketone bodies on FA oxidation. In order to prevent an early onset of diabetic cardiomyopathy and lipotoxicity, it is advisable to monitor plasma ketone body content in diabetic patients.

As the development of diabetes and, thus, the induction of diabetic cardiomyopathy and lipotoxicity take place in time, it is of interest to perform studies aiming to clarify the entire spectrum of changes occurring in the transition of the normal heart to the diabetic heart. To study which genes are involved in the transition, it is advisable to use the micro-array technique using cardiac specific mRNA chips. This would enable the possibility to detect genes which become either up-regulated or downregulated. The same regime should be applied to the identification of proteins which might play a role in this transition. A technique that can be used, which has sufficient throughput to identify a large number of proteins, is high-resolution two-dimensional gel electrophoresis followed by peptide mass fingerprinting ${ }^{74}$.

Even now, there is a lack of knowledge concerning the precise pathways responsible for the alterations in gene expression observed during diabetes. Therefore, more research needs to be done to identify the mechanisms by which gene expression is regulated in the diabetic heart and to identify sensors used to achieve this regulation.

At the level of lipotoxicity, the need for knowledge is even more stressing. To describe the precise nature and cause of lipotoxicity and the relationship with diabetes in the course of its development needs to be clarified. Therefore, the pathophysiological consequences of the increased lipid burden in diabetic subjects have to be investigated. New insights in lipotoxicity will hopefully lead to novel treatments, such as the development of compounds which ideally would prevent, but at least should be able to attenuate the lipotoxic effects in cardiac tissue.

Considering the limited knowledge of the role of protein acylation and signal transduction in diabetes, there is need for more research. The results 
in chapter 4 , indicated that protein palmitoylation might play a role in diabetes, as the thio-esterified fatty acyl moieties are significantly increased in diabetic myocardium. To gain more insight in the exact role of protein palmitoylation, it would be necessary to identify proteins which become covalently modified with fatty acyl moleties, including the quantity of the identified proteins. This would require 2-D gel-electroforesis in combination with mass-spectrometry, with appropriate resolution and sensitivity to identify and characterize the modified proteins ${ }^{75}$.

Finally, there is a great need for detailed studies in diabetic cardiomyopathies in the clinical setting to extrapolate the findings in experimental animals, isolated hearts and isolated cardiomyocytes to the diabetic patient. The collected data will lead to an increased understanding of the process underlying diabetes and will eventually lead to better possibilities for treating patients suffering, among other, from diabetic cardiomyopathy. 


\section{References}

1. Lewis GF, Carpentier A, Adell $K$ and Giacca $A$. Disordered fat storage and mobilization the pathogenesis of insulin resulstance and type 2 diabetes. Endocr Rev 23:201-229, 2002.

2. McGarry JD. Banting lecture 2001: dysiregulation of fatty acid metabolism in the etiology of type 2 diabetes. Diabetes 51: 7-18, 2002.

3. Taegtmeyer $\mathrm{H}$, MeNulty $\mathrm{P}$ and Young $\mathrm{ME}$. Adaptation and maladaptation of the heart in diabetes: Part I: general concepts. Circulation 105: 1727-1733, 2002.

4. Young ME, McNulty $P$ and Taegtmeyer $H$. Adaptation and maladaptation of the heart in diabetes: Part II: potential mechanisms. Circulation 105: 1861-1870, 2002.

5. Christe ME and Rodgers RL. Cardiac glucose and fatty acid oxidation in the streptozotocininduced diabetic spontaneously hypertensive rat. Hypertension $25: 235-241,1995$.

6. Rodrigues $B$ and McNeill $\mathbf{J H}$. The diabetic heart: metabolic causes for the development of a Cardiomyopathy. Cardiovasc Res 26: 913-922, 1992.

7. Saddlk $M$ and Lopaschulk GD. Triacylglycerol turnover in isolated working hearts of acutely diabetic rats. Can I Physiol Pharmacol 72: 1110-1119, 1994.

8. Turpeinen AK, Kuikka JT, Vanninen E and Uusitupa MI. Abnormal myocardial kinetics of 1.23i-heptadecanoic acid in subjects with impaired glucose tolerance. Diabetologia 40: 541-549, 1997.

9. Zorzano A, Sevilla L, Camps $M$, Becker C, Meyer J, Kammermeier H, Munoz $P_{\text {, Guma A, }}$ Testar X, Palacin M, Blasi J and Fischer $Y$. Regulation of glucose transport, and glucose transporters expression and trafficking in the heart: studies in cardiac myocytes. Am I Cardiol 80: 65A-76A, 1997.

10. Kuo TH, Giacomelli F, Wiener J and Lapanowski-Netzell K. Pyruvate dehydrogenase activity in cardiac mitochondria from genetically diabetic mice. Diabetes 34: 1075-1081, 1985.

11. Yki-Jarvinen. Glucose toxicity. Endocr Rev 13: 415-431, 1992.

12. Laffel L. Ketone bodies: a review of physiology, pathophysiology and application of monitoring to diabetes. Diabetes Metab Res Rev 15: 412-426, 1999.

13. de Vries JE, Vork $M M$, Roemen TH, de Jong YF, Cleutjens JP, Van der Vusse GJ and Van Bilsen $M$. Saturated but not mono-unsaturated fatty acids induce apoptotic cell death in neonatal rat ventricular myocytes. J Lipid Res 38: 1384-1394, 1997.

14. Epand RM. Lipid polymorphism and protein-lipid interactions. Biachim Biophys Acta 1376: $353-368,1998$.

15. Dyntar D, Eppenberger-Eberhardt $M$, Maedler $K$, Pruschy $M$, Eppenberger HM, Spinas GA and Donath MY. Glucose and palmitic acid induce degeneration of myofibrils and modulate apoptosis in rat adult cardiomyocytes. Diabetes 50: 2105-2113, 2001.

16. Zhou YT, Grayburn P, Karim A, Shimabukuro M, Higa M, Baetens D, Orci L and Unger RH. Lipotoxic heart disease in obese rats: implications for human obesity. Proc Natl Acad SciU S.A 97: 1784-1789, 2000. 
17. Chiu HC, Kovacs A, Ford DA, Hsu FF, Garcia R, Herrero P, Saffitz JE and Schaffer JE. A novel mouse model of lipotoxic cardiomyopathy. J Clin Imvest 107: 813-822, 2001.

18. Liang: $Q$, Carlson EC, Donthi RV, Kralik PM, Shen $X$ and Epstein PN. Overexpression of metallothionein reduces diabetic cardiomyopathy. Diabetes 51:174-181, 2002.

19. Chao H, Martin GG, Russell WK, Waghela SD, Russell DH, Schroeder F and Kier AB. Membrane charge and curvature determine interaction with acyl-COA binding protein (ACBP) and fatty acyl-CoA targeting. Biochemistry 41: 105.40-10553, 2002.

20. Paulson DJ and Crass MF, 3rd. Endogenous triacylglycerol metabolism in diabetic heart. Am JPhysiol 242: H1084-1094, 1982.

21. Nawrocki A, Gorska $\mathbf{M}$, Wojcik B and Buslowska A. Effect of streptozotocin diabetes on fatty acid content and composition of the heart lipids in the rat. Rocz Akad Med Bialymst 44: $170-179,1999$.

22. Aoshima S, Fujisawa S and Kobayashi A. Changes in the subcellular distribution of free carnitine and its acyl derivatives in diabetic rat hearts following treatment with $L$ carnitine. Jpn Heart J 34: 763-772, 1993.

23. Mokhtar N, Rousseau-Migneron S, Tancrede $G$ and Nadeau A. Physical training attenuates phosphocreatine and long-chain acyl-CoA alterations in diabetic rat heart. J Appl Physiol 74: 1785-1790, 1993.

24. Van der Vusse GJ, Glatz JF, Stam HC and Reneman RS. Fatty acid homeostasis in the normoxic and ischemic heart. Physiol Rev 72: 881-940, 1992.

25. Dunphy JT and Linder ME. Signalling functions of protein palmitoylation. Biochim Biophys Acta $1436: 245-261,1998$.

26. MCCabe JB and Berthiaume LG. Functional roles for fatty acylated amino-terminal domains in subcellular localization. Mol Biol Cell 10: 3771-3786, 1999.

27. Resh MD. Fatty acylation of proteins: new insights into membrane targeting of myristoylated and pallmitoylated proteins. Biochim Biophys Acta 1451: 1-16, 1999.

28. Stoffel RH, Inglese $J_{3}$ Macrae AD, Lefkowitz RJ and Premont RT. Palmitoylation increases the kinase activity of the $G$ protein-coupled receptor kinase, GRK6. Biochemistry 37 : 16053-16059, 1998.

29. Yang $S$, Zhang $L$ and Huang $Y$. Membrane association and conformational change of palmitoylated G(o)alpha. FEBS Lett 498: 76-81, 2001.

30. Resh MD. Regulation of cellular signalling by fatty acid acylation and prenylation of sigmal transduction proteins. Cell Signal 8: 403-412, 1996.

31. Towler DA, Eubanks SR, Towery DS, Adams SP and Glaser L. Amino-terminal processing of proteins by $\mathrm{N}$-myristoylation. Substrate specificity of $\mathrm{N}$-myristoyl transferase. $I$ Biol Chem 262: $1030-1036,1987$.

32. Boutin JA. Myristoylation. Cell Signal 9: 15-35, 1997.

33. Raju RV, Anderson JW, Datla RS and Sharma RK. Molecular cloning and biochemical characterization of bovine spleen myristoyll CoA:protein N-myristoyltransferase. Arch Biochem Biophys 348: 134-142, 1997. 


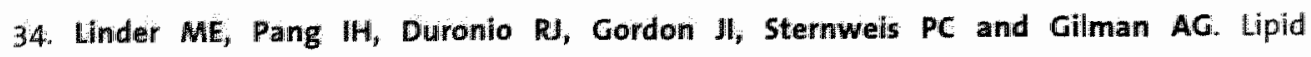
modifications of $G$ protein subunits. Myristoylation of Go alpha increases its affinity for beta gamma. J Biol Chem 266: 4654-4659, 1991.

35. Ross EM. Protein modification. Paimitoylation in G-proteiln signaling pathways. Curr Biol 5 : $107-109,1995$.

36. Qanbar $\mathbb{R}$ and Bouvier $\mathbf{M}$. Role of palmitoylation/depalmitoylation reactions in G-proteincoupled receptor function. Pharmacol Ther $97: 1-33,2003$.

37. King MJ, Pugazhenthi 5, Khandelwal RL and Sharma RK. Membrane-associated Nmyristoy/transferase activity is reduced in obese (fa/fa) Zucker rat liver. Biochem Biophys Res Commun 196: 665-670, 1993.

38. Van der Lee KA, De Brouwer KJF, Van der Vusse GI and Van Bilsen M. Fatty acid-regulated gene expression in the heart: Involvement of peroxisome proliferator-activated receptors. Recent Res. Devel. Lipids. 4: 25-38, 2000.

39. Barger PM and Kelly DP. PPAR signaling in the control of cardiac energy metabolism. Trends Cardiovasc Med 10: 238-245, 2000.

40. Latruffe $\mathbf{N}$ and Varnecq J. Peroxisome proliferators and peroxisome prolliferator activated receptors (PPARs) as regulators of lipid metabolism. Biochimie 79: 81-94, 1997.

41. Taegtmeyer H. Genetics of energetics: transcriptional responses in cardiac metabolis $\mathrm{m}$. Ann Bjomed Eng 28: 871-876, 2000.

42. Van der Lee KA, Vork MM, De Vries JE, Willemsem $\mathbf{P H}_{\mu}$ Glatz JF, Reneman RS, Van der Vusse $G J$ and Van Bilsen $M$. Long-chain fatty acid-induced changes in gene expression in neonatal cardiac myocytes. J Lipid Res 41: 41-47, 2000.

43. Gulilick T, Crescil S, Caira T, Moore DD and Kelly DP. The peroxisome proliferator-activated receptor regulates mitochondrial fatty acid oxidative enzyme gene expression. Proc NatI Acad SCi U SA 91: 11012-11016, 1994.

44. Brandt JM, Djouadi F and Kelly DP. Fatty acids activate transcription of the muscle carnitine palmitoyltransferase I gene in cardiac myocytes via the peroxisome proliferatoractivated receptor alpha. J Biol Chem 273:23786-23792, 1998.

45. Young ME, Patill S, Ying J, Depre C, Ahuja HS, Shipley GL, Stepkowski SM, Davies PJ and Taegtmeyer $H$. Uncoupling protein 3 transcription is regulated by peroxilsame proliferatoractivated receptor (alpha) in the adult rodent heart. Faseb $f$ 15: 833-845, 2001.

46. Young ME, Goodwin GW, Ying J, Guthrie P, Wilson CR, Laws FA and Taegtmeyer $H$. Regulation of cardiac and skeletal muscle malonyl-CoA decarboxylase by fatty acids. Am J Physiol Endocrinol Metab 280: E471-479, 2001.

47. Nathan DM, Lou P and Avruch J. Intensive conventional and insulin pump therapies in adult type I diabetes. A crossover study. Ann Intern Med 97: 31-36, 1982.

48. Poole RC and Halestrap AP. Transport of lactate and other monocarboxylates across mammalian plasma membranes. Am J Physiol 264: C761-782, 1993. 
49. Bleber LL, Emaus R, Valkner K and Farrell S. Possible functions of short-chain and mediumchain carnitine acyltransferases. Fed Proc 41: 2858-2862, 1982.

50. Brass EP and Hoppel CL. Effect of carnitine on mitachondrial oxidation of palmitoylearnitine. Biochem/188: 451-458, 1980.

51. Ramsay RR and Arduini A. The carnitine acyltransferases and their role in modulating acylCoA pools. Arch Biochem Biophys 302: 307-314, 1993.

52. Arsenian MA. Carnitine and its derivatives in cardiovascular disease. Prog Cardiovasc Dis 40: 265i-286, 1997.

53. Coker $\mathbf{M}$, Coker C, Darcan $\mathbf{S}_{\text {, Can }}$, Orbak $\mathbf{Z}$ and Goksen D. Carnitine metabolism in diabetes mellitus. J Pediatr Endocrinol Metab 15: 841-849, 2002.

54. McGarry JD and Brown NF. The mitochondrial carnitine palmitoyltransferase system. From concept to molecular analysis. Eur J Biochem 244: 1-14, 1997.

55. Goodwin GW and Taegtmeyer $H$. Regulation of fatty acid oxidation of the heart by MCD and ACC during contractile stimulation. Am I Physiol 277: E772-777, 1999.

56. Merrill GF, Kurth EJ, Rasmussen BB and Winder WW. Influence of malonyl-CoA and palmitate concentration on rate of palmitate oxidation in rat muscle. $\int$ Appl Physiol 85 : 1909-1914, 1998.

57. Saddik M, Gamble J, Witters LA and Lopaschuk GD. Acetyl-CoA carboxylase regulation of fatty acid oxidation in the heart. I Biol Chem 268: 25836-25845, 1993.

58. Kerner $\$ and Hoppel $C$. Genetic disorders of carnitine metabolism and their nutritional management. Annu Rev Nutr 18: 179-206, 1998.

59. Luiken JJ, van Nieuwenhoven FA, America G, van der Vusse GJ and Glatz JF. Uptake and metabolism of palmitate by isolated cardiac myocytes from adult rats: involvement of sarcolemmal proteins. J Lipid Res 38: 745-758., 1997.

60. Schmidt-Schweda $S$ and Holubarsch C. First clinical trial with etomoxir in patients with chronic congestive heart failure. Clin Sci (Lond) 99: 27-35, 2000.

61. Declercq PE, Falck JR, Kuwajima $M$, Tyminsk" $H$, Foster DW and McGarry JD. Characterization of the mitochondrial carnitine palmitoyltransferase enzyme system. 1. Use of inhibitors. J Biol Chem 262: 9812-9821, 1987.

62. Rupp $H$, Elimban $\mathbf{V}$ and Dhalla NS. Modification of subcellular organelles in pressureaverloaded heart by etomoxir, a carnitine palmitoyltransferase linhibitor. Faseb J $6: 2349$ $2353,1992$.

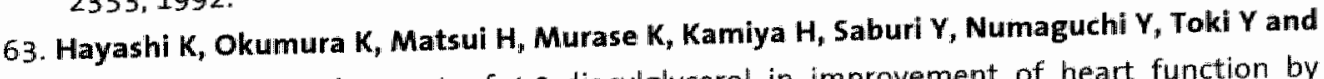
Hayakawa $T$. Involvement of 1,2-diacylglycerol in improvement of heart function by etomoxir in diabetic rats. Life Sci 68: 1515-1526, 2001.

64. Dobbins RL, Szczepaniak LS, Bently B, Esser $V$ and Myhill I. Prolonged inhibition of muscle carnitine palmitoyltransferase-1 promotes intramyocellular lipid accumulation and insulin resilstance in rats. Diabetes 50: 123-130, 2001. 
65. Cabrero A, Merlos M, Laguna JC and Carrera MV. Down-regulation of acyl-CoA oxidase gene expression and increased NF-kB activity in etomoxir-induced cardiac hypertrophy. $J$ Lipid Res $44: 388-398,2003$.

66. Roth AF, Feng $Y$, Chen L and Davis NG. The yeast DHHC cysteine-rich domain protein Akr1p is a palmitoyl transferase. J Cell Biol 159: 23-28, 2002.

67. Schmidt MF, Mcllhinney RA and Burns GR. Palmitoylation of endogenous and viral acceptor proteins by fatty acyltransferase (PAT) present in erythrocyte ghosts and in placental membranes. Biochim Biophys Acta 1257: 205-213, 1995.

68. Berthiaume L and Resh MD. Biochemical characterization of a palmitoyl acyltransferase activity that palmitoylates myristoylated proteins. J Biol Chem 270: 22399-22405, 1995.

69. Martens FM, Vissieren FL, Lemay J, de Koning EJ and Rabelink TJ. Metabolic and additional vascular effects of thiazolidinediones. Drugs 62: 1463-1480, 2002.

70. Vazquez $M$, Silvestre JS and Prous JR. Experimental approaches to study PPAR gamma agonists as antidiabetic drugs. Methods Find Exp Clin Pharmacol 24:515-523, 2002.

71. Larsen TM, Toubro $\mathbf{S}$ and Astrup A. PPARgamma agonists in the treatment of type II diabetes: is increased fatness commensurate with long-term efficacy? Int $I$ Obes Relat Metab Disord 27: 147-161, 2003.

72. Hamsen BC. Adipogensis and obesity. PPARs: Transcriptional regulators of metabolism and metabolic disease, Keystone, Colorado, 2003, p. 34.

73. Oliver WR, Jr., Shenk JL, Snaith MR, Russell CS, Plunket KD, Bodkin NL, Lewis MC, Winegar DA, Sznaidman ML, Lambert $M H_{\text {, }}$ Xu HE, Sternbach DD, Kliewer SA, Hansen BC and Willson TM. A selective peroxisome proliferator-activated receptor delta agonist promotes reverse cholesteral transport. Proc Nati Acad Sci U S A 98: 5306-5311, 2001.

74. Wilkins MR, Gasteiger E, Gooley AA, Herbert BR, Molloy MP, Binz PA, Ou K, Sanchez JC, Baïroch A, Williams KL and Hochstrasser DF. High-throughput Mass Spectrometric Discovery of Protein Post- translational Modifications. J Mol Biol 289: 645-657, 1999.

75. Bienvenut WV, Deon $C$, Pasquarello $C$, Campbell JM, Sanchez JC, Vestal ML and Hochstrasser DF. Matrix-assisted laser desorption/ionization-tandem mass spectrometry with high resolution and sensitivity for identification and characterization of proteins. Proteomics 2: 868-876, 2002 . 


\section{Summary}

In the heart the main supply of energy is the oxidation of long-chain fatty acids (FA), which contributes for up to $60 \%$ of the cardiac energy need under normal physiological conditions. Besides FA, the heart is capable to use substrates such as lactate, pyruvate, ketone bodies and glucose to fulfil its energy requirements.

During several pathophysiological states, such as diabetes, the relative contribution of the substrates the heart can utilize for energy conversion is altered. The current paradigm concerning diabetes mellitus, a condition characterized primarily by lack of insulin or insulin action, states that during diabetes the contribution of FA to the total cardiac energy need are increased at the expense of glucose utilization.

The research described in this thesis is based on two separate but intertwined paths of investigation. The first path is aimed at gaining insight in the process of protein acylation, which means the covalent attachment of FA derivatives to intracellular proteins. The second research line of this thesis is to elucidate various aspects of FA handling in the diabetic heart, such as the extent of FA oxidation and esterification in this organ. The two paths converge in investigations of alterations in cardiac FA handling under diabetic conditions and the impact thereof on protein acylation.

In the present thesis a multitude of approaches is used which may not only lead to new insights in the role of protein acylation in the diabetic heart but also to knowledge challenging the current paradigm concerning cardiac FA utilization in diabetic conditions.

Chapter 1 contains the introduction to the thesis. The role of FA in maintaining energy homeostasis is briefly discussed, with special reference to other roles of FA besides serving as energy substrate. This includes the transport of FA in combination with the various sites of action to which FA can be channelled. Furthermore, attention is paid to the incorporation of FA into various lipid pools such as phospholipids (PL) and triacylglycerols (TG), as well as the covalent attachment of FA derivatives to proteins. Finally, the research aims of this thesis are described in this chapter.

Chapter 2 gives an extensive overview in the critical steps concerning the handling and utilization of blood-borne FA up until the entering into mitochondria where the FA is oxidized for the formation of ATP. In addition, to gain more insight in the role of protein acylation, the two forms of protein acylation are described in detail. The processes underlying S-acylation and 
myristoylation and the consequences of these modifications are discussed. It illustrates the potential role of protein acylation as a mean to influence, for instance, signal transduction pathways and enzyme activity.

In chapter 3 the use of capillary gas chromatography in cardiac research is described. This method is a sensitive and reliable analytical technique which can provide information on the total amount of FA and the relative fatty acyl composition of FA and the esterified lipid pools, TG and PL, in cardiac tissue and blood plasma. It was found that in blood plasma of diabetic rats both total amounts of $F A$ and $P L$ are doubled, while the TG content was 5.4 fold increased. The total quantities of FA, TG and PL showed a different pattern in cardiac tissue, with a 4.8 fold increase of FA, a 2 fold increase of TG, while the PL pool remained stable. Furthermore, this chapter revealed significant differences in lipid profiles in cardiac tissue as well as blood plasma between control and diabetic rats, supporting earlier observations that in addition to carbohydrate handling, lipid metabolism is also affected during diabetes.

In chapter 4 the development of a model system is described which was used to study the features of S-acylation and myristoylation in more detail. For this purpose the $\mathrm{H} 9 \mathrm{c} 2$ cell line, originating from embryonic rat heart tissue, was used. The distribution and the incorporation of radioactive labelled palmitate and myristate into the various intracellular pools, such as lipids and proteins, were monitored. The outcome of this study showed that more than $99 \%$ of the labelled FA taken up by the cell was present in the combined lipid pools, while 0.3 percent of less became covalently attached to proteins. In addition, the effect of increased availability of FA on the amount of acylated proteins as well as the pattern of covalently modified proteins was investigated. It was observed that the rate of protein acylation increased when the amount of extracellular FA was enhanced. Applying autoradiography to visualize radioactively labelled proteins demonstrated that the increased amount of exogenous palmitate commonly led to a decreased visibility of most protein bands, with the most striking exception of a $22 \mathrm{kDa}$ protein band of a yet unknown protein. Furthermore, two known inhibitors of protein acylation, cerulenin and tunicamycin, were used to explore whether this protein modification could be inhibited in the present experimental setting. Both cerulenin and tunicamycin were able to inhibit protein acylation in the $\mathrm{H} 9 \mathrm{c} 2$ cells and the mechanism achieving this is most likely different between the two inhibitors.

Chapter 5 indicates that capillary gas chromatography can also be used to determine the absolute amount and the relative composition of the fatty acyl chains which are covalently bound to proteins in cardiac tissue derived 
from control and diabetic rats. This study showed that there are major differences between S-acylation and myristoylation in response to diabetes. Although the substrate required for both processes, i.e. FA, is increased, only the amount of S-acylated proteins was significantly enhanced while the amount of myristoylated proteins remained equal to that in control cardiac tissue. Furthermore, this chapter illustrates that ketone bodies, a substrate which can be oxidized by the heart and the plasma concentration of which is increased under diabetic circumstances, are capable to significantly elevate $\mathrm{S}$-acylation of proteins in cardiac myocytes derived from diabetic rats. This suggests that the presence of ketone bodies in the diabetic animal is a possible explanation for the significantly increased amount of 5-acylated proteins in diabetic cardiac tissue.

In chapter 6 the effect of ketone bodies on several aspects of cardiac fatty acid handling was investigated. To this end, isolated cardiac myocytes derived from control and diabetic rats were used in a variety of experimental conditions mimicking as much as possible the in situ circumstances in control and diabetic animals. It was shown that the ketone bodies, acetoacetate (ACAC) and 3- $\beta$-hydroxybutyrate $(3 \mathrm{HB})$, were not able to influence initial uptake rate either in control or diabetic cardiomyoctes. However, experiments studying FA oxidation showed that ACAC significantly inhibited FA oxidation in both control and diabetic cardiomyocytes, whereas $3 \mathrm{HB}$ did not exert any influence on FA oxidation. In addition, diabetic cardiomyocytes incubated under diabetic conditions showed that exposure to ACAC was responsible for an increase in unmetabolized FA inside the cells. Taken together, these findings indicate that ketone bodies are playing an important role in compromising cardiac FA handling under diabetic conditions.

Chapter 7 deals with an explorative study which concerns the metabolic and genetic changes occurring in the heart of a diabetic rat. At the metabolic level, alterations in substrate and co-factor content were measured. An increase in both blood plasma as well as cardiac tissue of almost all substrates was observed, while at the intracellular co-factor level the free carnitine, total carnitine as well as the free COA pool showed a significant decline. Furthermore, the activity of enzymes playing a key role in cardiac energy conversion was determined, with as most striking results a decline in the pyruvate dehydrogenase activity which is most likely a consequence of the enhanced activity of pyruvate dehydrogenase kinase. At the genetic level, mRNA of proteins and enzymes involved in cardiac glucose and FA utilization was determined, with special attention to uncoupling protein 3. A 4-fold increase in mRNA content of UCP3 associated with a 16-fold increase of this 


\section{6}

member of the uncoupling protein family at the protein level was observed. In addition, the effect of ketone bodies on the MRNA levels on a number of metabolic genes was examined. Finally, the effect of FA and/or ketone bodies, either $A C A C$ or $3 \mathrm{HB}$, on the activity of carnitine palmitoyltransferase 1 (CPT1) was measured with the use of transfected neonatal cardiomyocytes. It was found that $3 \mathrm{HB}$ was able to suppress promoter activity of CPT1 in contrast to ACAC, thereby elucidating another level of regulation and complexity of cardiac gene expression. Taken together, this chapter illustrates that the heart adapts in a multiple fashion to the altered circumstances to which it is exposed during diabetes mellitus.

The final chapter of this thesis, chapter 8 , discusses the major findings and gives suggestions for future research. The impact of the disturbed FA handling on a variety of features, such as signal transduction and lipotoxicity, as seen in diabetes are discussed. The present findings suggest that measures aiming to stimulate cardiac FA oxidation rather than to inhibit cardiac FA utilization should be considered as novel therapeutic interventions to mitigate the lipotoxic effects of FA accumulation in the diabetic heart. 


\section{Samenvatting}

De voornaamste bron van energie in het hart is de oxidatie van lang-ketenige vetzuren, welke onder fysiologische omstandigheden voor ongeveer $60 \%$ bijdragen aan de energie behoefte van het hart. Om in de energie behoefte te voorzien is het hart, naast vetzuren, ook in staat om andere substraten, zoals lactaat, pyruvaat, ketonlichamen en glucose te oxideren.

Verschillende pathofysiologische omstandigheden, zoals diabetes, veroorzaken een verschuiving in de relatieve bijdrage van de diverse substraten aan de energie omzetting in het hart. Het huidige paradigma stelt dat gedurende diabetes mellitus, een ziektebeeld dat gekarakteriseerd wordt door een gebrek aan insuline of de werking van insuline, de bijdrage van vetzuren aan de totale energie behoefte van het hart is verhoogd ten koste van glucose.

Het onderzoek dat beschreven wordt in dit proefschrift is gebaseerd op twee verschillende maar in elkaar verweven onderzoekslijnen. Het eerste deel van het proefschrift is gericht op het verkrijgen van inzicht in het proces van eiwit-acylering, een proces dat gekenmerkt wordt door een covalente binding van vetzuurderivaten aan intracellulaire eiwitten. Het tweede deel van dit proefschrift belicht de verschillende aspecten van vetzuurgebruik, onder andere vetzuuroxidatie en -esterificatie in het diabete hart. Beide aspecten worden verenigd in onderzoek naar de veranderingen in vetzuurgebruik en de impact daarvan op het eiwit acyleringsproces onder diabete omstandigheden.

In dit proefschrift zijn diverse benaderingen gebruikt die niet alleen tot nieuwe inzichten leiden in de mogelijke betekenis van eiwit-acylering in het diabete hart, maar ook vraagtekens plaatsen bij het huidige paradigma betreffende het vetzuurgebruik in het diabete hart.

Hoofdstuk 1 bevat de inleiding van dit proefschrift. De roll van vetzuren in het handhaven van de lipidenhomeostase wordt kort besproken, met speciale aandacht voor andere aspecten van vetzuren dan alleen het dienen als energie-leverend substraat. Dit betreft het transport van vetzuren in combinatie met de verschillende plaatsen waar vetzuren hun biologische werking kunnen uitoefenen. Verder is aandacht besteed aan de inbouw van vetzuren in diverse intracellulaire lipiden zoals fosfolipiden (PL) en triacylglycerolen (TG), alsmede de covalente binding van vetzuurderivaten aan eiwitten. Tot slot wordt in dit hoofdstuk het onderzoeksdoel van dit proefschrift besproken. 
Hoofdstuk 2 geeft een uitgebreid overzicht van belangrijke stappen in het gebruik van vetzuren die afkomstig zijn uit bloedplasma tot en met de opname in mitochondria waar vetzuren geoxideerd worden voor de vorming valn ATP. Om meer inzicht te verkrijgen in de rol van eiwit-acylering worden de twee verschillende vormen van acylering in detail besproken. De processen die ten grondslag liggen aan S-acylering en myristoylering en de consequenties van deze eiwitmodificatie worden toegelicht. Dit dient ter illustratie van de potentiële rol van eiwit-acylering als middel om bijvoorbeeld signaaltransductie-ketens te beïnvloeden.

In hoofdstuk 3 wordt beschreven hoe met behulp van capillaire gas chromatografie vetzuren bepaald kunnen worden. Dit is een gevoelige en betrouwbare analytische methode die informatie kan verschaffen over de totale hoeveelheid vetzuren en de relatieve samenstelling van vetzuren en veresterde lipiden, $\mathrm{TG}$ en $\mathrm{PL}$, in hartweefsel en in bloedplasma. In bloedplasma van diabete ratten is gevonden dat de totale hoeveelheid van vetzuren en PL verdubbeld is, terwijl de hoeveelheid TG ongeveer 5 maal verhoogd is. De totale hoeveelheden van vetzuren, TG en PL in hart weefsel laten een verschillend patroon zien: een 4.8 -voudige verhoging van vetzuren, een 2.0-voudige verhoging van TG, terwijl de hoeveelheid fosfolipiden niet veranderde. Tevens laat dit hoofdstuk significante verschillen in de vetzuur profielen zien in hartweefsel alsmede bloedplasma tussen controle en diabete ratten. Dit resultaat ondersteunt eerdere bevindingen dat naast het koolhydraatmetabolisme, ook het vetzuurmetabolisme is aangedaan onder diabete omstandigheden.

In hoofdstuk 4 wordt de ontwikkeling van een modelsysteem beschreven dat gebruikt is om de eigenschappen van S-acylering en myristoylering in detail te bestuderen. Voor dit doel is de $\mathrm{H} 9 \mathrm{c2}$ cellijn gebruikt, welke afkomstig is van embryonaal rattenhartweefsel. De distributie en de uiteindelijke inbouw van radioactief gelabeld palmitine zuur en myristine zuur in de verschillende weefsel fracties, zoals lipiden en eiwitten, zijn bepaald. De resultaten van deze studie laten zien dat meer dan $99 \%$ van de hoeveelheid opgenomen radioactief gemerkte vetzuren aanwezig zijn in de verschillende lipiden fracties, terwijl $0.3 \%$ of minder covalent gebonden worden aan eiwitten. Tevens werd het effect van het verhogen van de beschikbare hoeveelheid vetzuur op de hoeveelheid geacyleerde eiwitten als ook het patroon van de covalent-gemodificeerde eiwitten onderzocht. Het bleek dat de snelheid van eiwit-acylering toegenomen is bij een verhoogd extracellulair vetzuuraanbod. De toepassing van autoradiografie om de radioactief gemerkte eiwitten zichtbaar te maken toonde aan dat een verhoging van het vetzuur aanbod leidt tot een afname van de meerderheid 
van de zichtbare eiwit-banden. Een uitzondering hierop vormt een $22 \mathrm{kDa}$ band van een tot nu toe onbekend eiwit. Tevens werden twee inhibitoren van eiwit-acylering, namelijk cerulenine en tunicamycine, toegepast in dit experimentele model. Zowel cerulenine als tunicamycine waren in staat om eiwitacylering tot op zeker hoogte te remmen in de $\mathrm{H} 9 \mathrm{c2}$ cellijn. Tevens bleek dat het mechanisme waarmee eiwit-acylering geremd werd verschillend was tussen deze twee inhibitoren.

Hoofdstuk 5 laat zien dat capillaire gaschromatografie ook gebruikt kan worden om de absolute hoeveelheid en de relatieve samenstelling van de vetzuurketens die covalent gebonden zijn aan eiwitten te bepalen. Deze studie toonde aan dat er grote verschillen bestaan tussen S-acylering en myristoylering van eiwitten tussen diabete en controle harten. Ondanks het feit dat het substraat dat voor beide processen nodig is onder diabete omstandigheden is verhoogd, is alleen de hoeveelheid S-geacyleerde eiwitten significant toegenomen, terwijl de hoeveelheid gemyristoyleerde eiwitten niet toeneemt. Verder laat dit hoofdstuk zien dat keton-lichamen, een substraat dat verhoogd in bloedplasma aanwezig is en geoxideerd kan worden door de hartspier, in staat zijn om de mate van S-acylering van eiwitten significant te doen toenemen in hartspiercellen verkregen uit diabete ratten. Dit suggereert dat de toegenomen aanwezigheid van ketonlichamen in het diabete dier een mogelijke verklaring is voor de significant verhoogde aanwezigheid van S-geacyleerde eiwitten in diabeet hart weefsel.

In hoofdstuk 6 is de rol van keton-lichamen op diverse aspecten van vetzuurgebruik onderzocht. Hiervoor zijn geïsoleerde cardiomyocyten van controle en diabete ratten geïncubeerd onder experimentele condities die de in situ situatie zoveel mogelijk nabootsten. Hieruit bleek dat de ketonlichamen, acetoacetaat ( $A C A C$ ) en $3-\beta$-hydroxybutyraat $(3 \mathrm{HB})$, niet in staat waren om de initiële opname van vetzuren in controle en diabete cardiomyocyten te beïnloeden. Experimenten met betrekking tot vetzuuroxidatie laten echter zien dat ACAC in staat is om de vetzuuroxidatie significant te remmen in controle alsmede diabete hartspiercellen, terwijl 3 HB hiertoe niet in staat bleek te zijn. Daarbij komt dat diabete hartspiercellen geïncubeerd onder diabete omstandigheden lieten zien dat blootstelling aan ACAC verantwoordelijk is voor een toename van niet omgezet vetzuur in de cellen. Samenvattend, deze bevindingen tonen aan dat keton-lichamen een belangrijke rol spelen in de veranderde vetzuurhuishouding in het hart onder diabete omstandigheden.

Hoofdstuk 7 beschrijft een verkennende studie betreffende de metabole en genetische veranderingen die optreden in het hart van de diabete rat. Op het metabole niveau zijn de veranderingen in de hoeveelheden substrat en 
co-factoren gemeten. In zowel bloedplasma als hartweefsel waren bijna alle substraat niveau's verhoogd, terwill het intracellulaire cofactor gehalte van vrij carnitine, totaal carnitine en de vrij CoA een significante afname liet zien. Bovendien werd de activiteit bepaald van enzymen die een sleutelrol spelen bij de energieomzetting in het hart, met als meest opvallende resultaat een afname in de pyruvaat dehydrogenase activiteit, waarschijnlijk als gevolg van de toegenomen activiteit van het pyruvaat dehydrogenase kinase. Op genetisch niveau werden de hoeveelheden mRNA bepaald van eiwitten en enzymen die betrokken zijn bij glucose- en vetzuurgebruik in het hart, met speciale aandacht voor uncoupling protein 3. Een 4 -voudige toename in het mRNA gehalte van dit eiwit ging gepaard met een 16-voudige toename op eiwitniveau. Voorts werd het effect van keton-lichamen op de hoeveelheden mRNA van een aantal metabole genen bestudeerd. Tenslotte werd de invloed van vetzuren en/of keton-lichamen (hetzij ACAc of $3 \mathrm{HB}$ ) op de activiteit van carnitine palmitoyl-transferase 1 (CPT1) gemeten door gebruik te maken van getransfecteerde neonatale cardiomyocyten. In tegenstelling tot ACAC bleek $3 \mathrm{HB}$ wel in staat om de CPT1 promoteractiviteit te onderdrukken, hetgeen de complexiteit van de regulatie van de expressie van metabole genen in het hart benadrukt. Samengevat illustreert dit hoofdstuk dat de hartspier zich op velerlei manieren aanpast aan de gewijzigde omstandigheden zoals die zich voordoen bij diabetes mellitus.

In het laatste hoofdstuk van dit proefschrift, hoofdstuk 8 , worden de belangrijkste bevindingen bediscussieerd en suggesties aangereikt voor toekomstig onderzoek. De mogeljke consequenties van het verstoorde vetzuurgebruik in het diabete hart voor processen zoals signaaltransductie en lipotoxiciteit, zoals aangetroffen bij diabetes, worden besproken. De huidige bevindingen suggereren dat ingrijpen met als doel het stimuleren van de vetzuuroxidatie in het hart in plaats van het remmen ervan beschouwd dient te worden als een potentiële therapeutische interventie om de lipotoxische effecten van vetzuurophoping in het diabete hart te verminderen. 


\section{List of publications}

D. P. Steenvoorden, D. M. Hasselbaink and G. M. Beijersberger van Henegouwen. Protection against UV-intermediates in human cells and mouse skin by gluthathione precursors: a comparison of $\mathrm{N}$-acetylcysteine and gluthathione ethylester. Photochem Photobiol 67: 651-656, 1998.

D. M. Hasselbaink, T. H. M. Roemen and G. J. van der Vusse. Determination of long-chain fatty acids in heart and skeletal muscle by capillary gas chromatography. Analytica Chimica Acta 465: 351-357, 2002.

G. J. van der Vusse, M. van Bilsen, J. F. C. Glatz, D. M. Hasselbaink and J. J. F. P. Luiken. Critical steps in cellular fatty acid uptake and utilization. Mol Cell Biochem 239: 9-15, 2002

D. M. Hasselbaink, T. H. M. Roemen and G. J. van der Vusse. Protein acylation in the cardiac muscle like cell line, H9c2. Mol Cell Biochem 239: 101-112, 2002

D. M. Hasselbaink, J. F. C. Glatz, J. J. F. P. Luiken, T. H. M. Roemen and G. J. van der Vusse. Ketone bodies disturb fatty acid handling in isolated cardiomyocytes derived from control and diabetic rats. Biochemical J 371: $753-760,2003$ 


\section{Curriculum Vitae}

Danny Hasselbaink werd op 31 maart 1973 geboren te Rotterdam. Na het afronden van de MAVO en HAVO behaalde hij in 1993 zijn VWO diploma op het Kalsbeek college te woerden. In datzelfde jaar starte hij de studie Biomedische Wetenschappen aan de Universiteit Leiden. Het wetenschappelijk onderzoek begon met het lopen van de hoofdvakstages bij de vakgroep farmacochemie onder begeleiding van Dr. D. P. T. Steenvoorden, en bij TNO preventie en gezondheid onder supervisie van Dr. B. J. M. van Vlijmen en Dr. B van de Water. Na zijn afstuderen in 1998, startte hij op 1 januari 1999 als assistent in opleiding bij de afdeling fysiologie aan de universiteit van Maastricht. Het onderzoek dat werd verricht staat beschreven in dit proefschrift. Momenteel is hij bezig zich te oriënteren op de arbeidsmarkt. 


\section{Dankwoord}

In 1998 ben ik vanuit het noorden, omdat vanuit maastricht nu eenmaal alles in het noorden en boven de rivieren is, naar beneden afgezakt om in maastricht te beginnen aan mijn promotieonderzoek, wat uiteindelijk geleid heeft tot dit boekje. Dit werk heb ik de afgelopen jaren niet alleen gedaan. Er zijn namelijk een groot aantal mensen die daar aan bij hebben gedragen.

Voordat ik begin met het bedanken van een aantal mensen, wil ik eerst nog even iets anders kwijt. Gedurende mijn AlO periode heb ik al die tijd met veel plezier in bemelen op de bemelerberg gewoond. Om aan te geven dat ik mijn hart toch wel een klein beetje verloren heb aan bemelen, de "bemelerboys" en maastricht (al zal ik dat hierna nooit meer herhalen), wil ik hier toch even iets in het sjengs zeggen.

In die veer jaor in Bemele höb iech daan wèl gein Mestreechs liere praote, mèh bin lech wel genóg ingebörregert um 't Mestreechs te liere verstoon. Dat allemaol met daank aon mien voetbalvrun oet Bemele en neet te vergete mien kollegaas. Allemaol zien ze d'r zoe aon geweend geraak tot iech in de buurt bin, tot ze gein "Hollands" mie praote es iech beijj hun in de buurt bin. Dat vin iech zoe geweldig, en nu weer naar het nederlands, en dat zal ik ook nooit vergeten! (Jodil, bedankt voor de vertaling!)

Dan nu weer verder met de orde van het dankwoord, om er toch enigzins nog een beetje structuur in te houden. Ger, als mijn directe begeleider en promotor hebben we veel tijd met elkaar door gebracht. Gedurende de uitgebreide donderdagochtend besprekingen, waar ik ook wel eens een keer te laat was, hebben we veel gediscussieërd en ik heb veel van je geleerd. Bij deze besprekingen was ook Theo menigmaal van de partij. Theo, zonder jou hulp was het lipiden werk wat in dit proefschrift staat beschreven veel minder prominent aanwezig geweest.

Nu dan naar mijn kamergenoten: ongeveer 3 jaar hebben Debby (van D), Jodil (of Jodel voor intimi), Joep (soepmaster J), en ik (beter bekend als de NAR) een kamer gedeeld. Het zou mij geen enkele moeite kosten om een heel boek te vullen met alle anekdotes en verhalen. Jammer genoeg is daar geen plek voor, maar wel voor een paar korte dingen. Debby, ondanks het sleutel incident is het meer dan goed gekomen. Ik weet dat ik je een foto op de kaft had belooft, maar dat is toch niet gelukt. Mag ik nu toch oppositie bij je komen voeren? Jodil, we hebben veel gemeenschappelijke interessen zoals, computers, muziek en films. Ik heb altijd genoten van de gesprekken die we hierover, en over dingen in het algemeen hebben gevoerd. Bedankt voor alles wat je voor me hebt gedaan. Joep, inmiddels ben je ook gepromoveerd. Kan me een groot aantal keren heugen dat ik weer eens de gang op gereden ben 
in mijn stoel omdat ik weer vervelend tegen jou en ledereen in onze kamer deed. Je hebt me kennis laten maken met het filmhuis, en we hebben daar menig juweeltje gezien. Inmiddels afgewisseld met de nodige avondjes techno. Geweldig dat je inmiddels in Amsterdam woont, dus alle tradities die we opgebouwd hebben kunnen nu dus gewoon worden doorgezet.

Danielle, Maurice, Roy (a.k.a Putterman), Andries (a.k.a. The Shadow) en Jolanda, Martijn, Hans, Kristel, Susan, Joost, Lilian en Mirjam, bedankt. Een aantal voor de dagelijks terugkerende lunch, erg gezellig. Verder de vele kopjes koffie, toch wel 1 van mijn eerste levensbehoeften, die ik met jullie in de koffie kamer heb gedronken, vaak met de nodige discussies over van alles en nog wat. De vele films de we gezien hebben in de bioscoop, menigmaal vooraf gegaan door restaurant of toch even snel snacken. Zall dat en jullie allemaal missen!

Van het CPV will ik met name Richard bedanken voor de vele ratten die hij voor mij behandeld heeft, en de rest van het CPV voor de vele liters suikerwater en schone kooien die nodig waren voor het verzorgen van mijn ratten.

En verder, mijn oude kamergenoten, Frank, Christine en Frans en Jan, Marc, Luc, Peter, Hans, Wil, Ferdy, Richard, Karin, Veerle, Anita, Clair, Jos en alle (oud)-medewerkers van Fysiologie die ik nog vergeten ben, bedankt.

Voor iedereen, ik wil jullie sowieso bedanken voor alle steun, in alle goede maar zeker ook in de slechte perioden die ik heb doorgemaakt, hier kan ik jullie echt niet genoeg voor bedanken.

Tot slot, al mijn ouders, Marga en niet te vergeten Sandra, mijn vriendin, steun en toeverlaat. Mede dankzij jullie ben ik wie ik ben en ook jullie hebben dus bijgedragen aan dit proefschrift.

\section{Danny}




\section{abbrevations}

$3 \mathrm{HB}$

$A C A C$

$A B P$

ACBP

$A C S$

ADP

ATP

BHT

BSA

CAT

CPT

DG

FA

FA-COA

FABPC

FABPpm

FAT/CD36

FATP

GLUT4

HKII

HPLC

LCAD

LPL

MA

PA

PDH

PDK4

PL

PPAR

SSO

STZ

TCA

TLC

TG

UCP3

VLDL
3- $\beta$-hydroxybutyrate acetoacetate

albumin binding protein

acyl-CoA binding protein

acyl-CoA synthetase

adenosine diphosphate

adenosine triphosphate

butylated hydroxytoluene

bovine serum albumin

carnitine acyltransferase

carnitine palmitoyl transferase

diacylglycerols

long-chain fatty acids

fatty acyl coenzyme A

cytoplasmic fatty acid binding protein

plasmalemmal fatty acid binding protein

fatty acid translocase

fatty acid transport protein

glucose transporter 4

hexokinase II

high performance liquid chromatography

long-chain acyl-CoA dehydrogenase

lipoprotein lipase

myristate

palmitate

pyruvate dehydrogenase

pyruvate dehydrogenase kinase 4

phospholipids

peroxisome proliferators activated receptors

sulfo-N-succinimidyl oleate

streptozotocin

tricarboxylic cycle

thin layer chromatography

triacylglycerols

uncoupling protein 3

very low density lipoprotein 